\title{
웹툰산업 해외진출 진흥 방안 연구
}

Study on Improvement for Overseas

Expansion of the Webtoon Industry 



\section{웹툰산업 해외진출 진흥 방안 연구}

Study on Improvement for Overseas Expansion of the Webtoon Industry

양지훈·박찬욱·김병수·박석환 

연구책임

양지훈 한국문화관광연구원 연구원

공동연구

박찬욱 한국문화관광연구원 연구위원

김병수 목원대학교 웹툰애니메이션게임학부 교수

박석환 한국영상대학교 만화웹툰콘텐츠학과 교수 

웹툰산업 해외진출 진흥 방안 연구

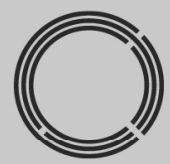

연구개요 



\section{1. 서론}

\section{가. 연구 배경 및 목적}

- 연구 배경

- 국내에서 발생한 새로운 디지털만화 방식인 웹툰은 '콘텐츠의 디지털화' 바람에 가장 적극적으로 적응하고 진화하면서 하나의 디지털 만화 장르로 산업을 형성 하였으며, 국내에서 점점 해외로 산업적 성장을 확대

- 게다가 코로나 19 발 디지털화 전환 요구는 전 세계 만화산업의 디지털 변화 기 조와 맞물리면서 웹툰산업이 한 단계 도약할 수 있는 기회로 작용

- 다만, 글로벌 관점에서 웹툰산업은 성장성은 높지만 아직도 글로벌 인지도와 디 지털만화에서의 시장점유율이 낮고, 절대적 시장규모 자체가 작음

- 따라서 글로벌에서의 웹툰산업의 현재 위치와 현황을 객관적으로 파악하고 극 복해야할 문제점과 개선점을 도출하여 웹툰산업의 해외진출 본격화를 이끌 수 있는 정책마련이 필요한 시점

[그림 1] 연구의 배경 및 목적

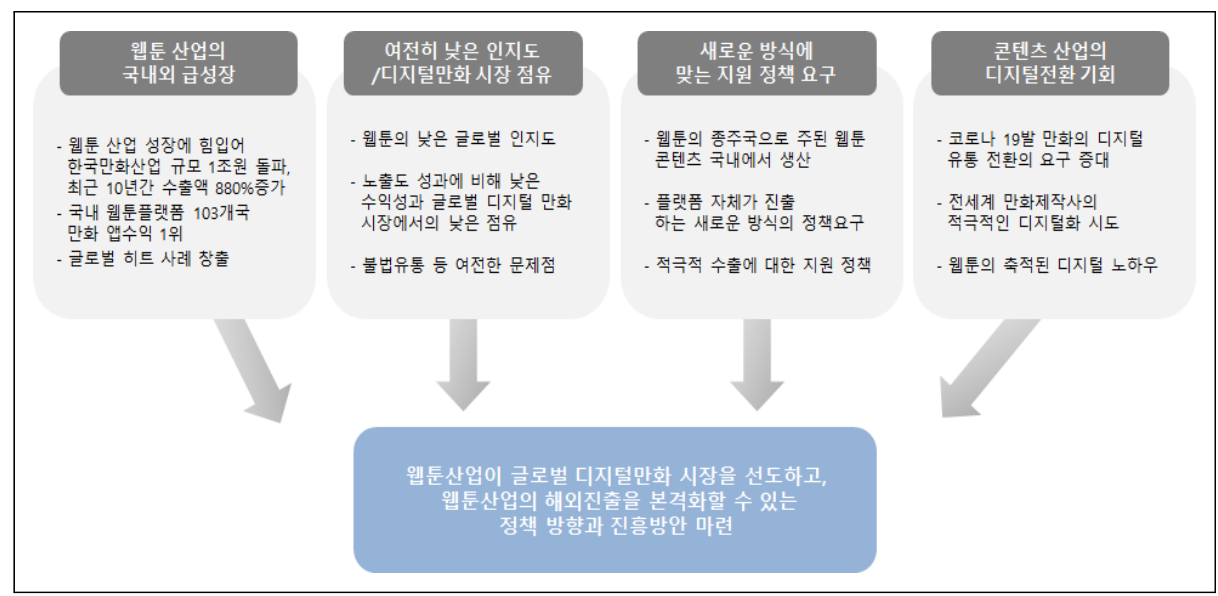

- 연구 목적

- 해외진출이 본격화되고 있는 웹툰산업의 현황과 차별점을 파악하는 한편, 해외 디지털 만화 현황을 객관적으로 분석하여 웹툰산업의 해외진출 활성화에 기여 할 수 있는 전략방향과 방안을 도출 


\section{나. 연구 범위 및 방법}

- 연구 범위

- (시간적 범위) 웹툰이 발생한 2003년부터 2021년 9월(연구 시점)까지

- (공간적 범위) 온라인 기반(네트워크, 디바이스 등)이 갖춰져 있어 웹툰이 진출 할 수 있는 전 세계 국가와 지역

- (정책대상 범위) 웹툰산업 관련 관계자(작가, 플랫폼, 에이전시, 스튜디오)

- 연구 방법

- (문헌 연구) 웹툰산업 및 콘텐츠 해외진출 관련 논문, 연구보고서, 증권 리포트, 민간기관 리포트 등 기관자료, 통계자료, 기업자료 등 다양한 정보채널을 통해 자료를 확보하고 이를 검토

- (전문가 및 업계 인터뷰) 웹툰 작가, 웹툰 업계전문가, 웹툰 관련 학계 전문가, 연구계 및 관계 전문가를 대상으로 심층인터뷰를 진행

- (해외 사례분석) 만화 선도국으로 분류할 수 있는 일본과 미국의 만화시장 고도 화 과정에 대해 사례분석을 진행

- (지원 정책 분석) 상위계획 검토 및 현행 웹툰 해외진출 관련 지원사업을 분석 [그림 2] 연구 내용 및 방법

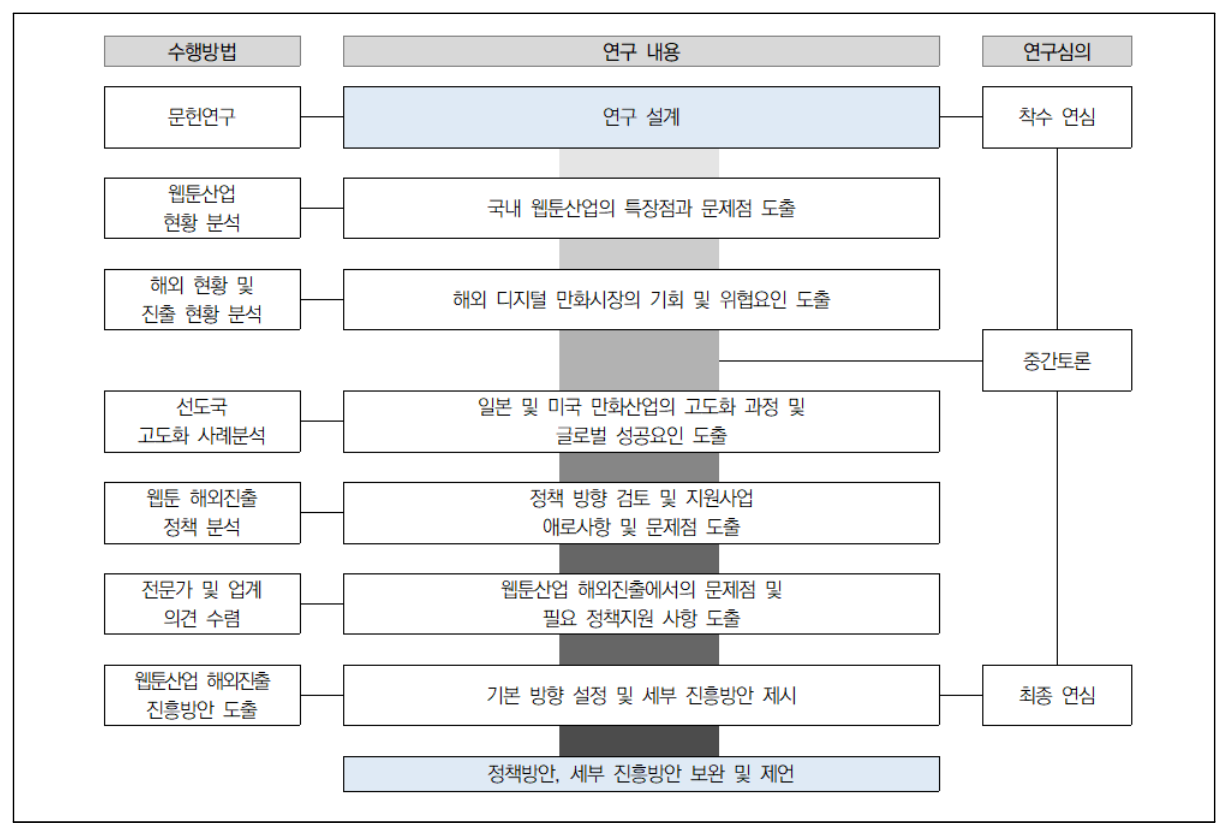




\section{2. 웹툰산업 현황}

\section{가. 수명주기 상에서의 웹툰산업}

- 국내의 웹툰산업: 2020 년대(현재)는 성장기에서 성숙기에 위치

- 국내에서의 웹툰산업은 2000년대 포털을 중심으로 웹툰이 시작된 도입기를 지

나 2010년대 유료화를 통해 본격적으로 산업적 성장기에 이름

- 2020년대인 현 시점은 공급과 수요가 모두 급성장하고 비즈니스 모델이 정교화 되는 성장기와 성숙기 사이에 위치

- 해외에서의 웹툰산업: 2020년대(현재)는 도입기에서 성장기 초에 위치

- 2010년부터 해외진출이 시작되어 2020년 들어 앱시장을 중심으로 해외진출을 본격화

- 다만 아직 전 세계적으로 인지도가 낮고 수익이 상대적으로 낮아 여전히 도입기 에서 성장기 초 사이에 위치하고 있음

- 글로벌 확장을 시작하는 도입기에서 성장기 초기국면에 위치해 있기 때문에 디 지털 만화시장 선점을 위한 적극적인 시장침투가 필요

[그림 3] 국내 및 해외에서의 웹툰산업의 수명주기 상 현재 위치

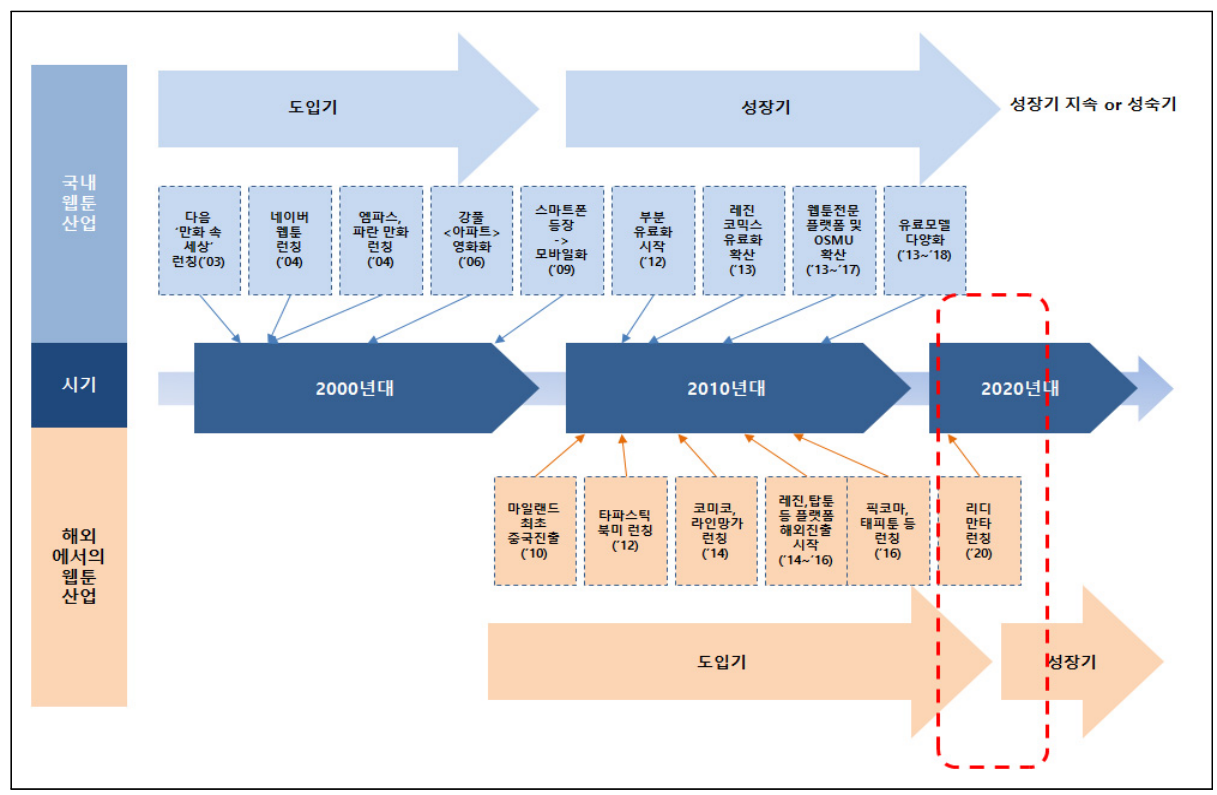




\section{나. 웹툰산업 주요 이슈 및 트렌드}

- (높아진 웹툰의 IP 가치) 게임, 애니메이션, 영화, 드라마 등 웹툰 콘텐츠의 IP를 원천으로 성공을 거둔 사례가 다양하게 발생

- (웹툰 유통 다변화) 독립만화를 중심으로 소셜미디어(SNS), 크라우드 펀딩, 소규모 출판사, 오픈 플랫폼 등 대형 웹툰 플랫폼을 외 다양한 방식의 웹툰 유통방식 발생

- (여전한 불법 유통(저작권) 문제) 웹툰의 유료화가 시작한 순간부터 현재까지 웹툰 불법 유통은 지속되고 있으며, 2018년 〈밤토끼〉 폐쇄이후에도 다른 유사 사이트 가 개설되면서 해결하기 어려운 난제로 자리함

- (웹소설 원작 웹툰 콘텐츠의 활성화/제작의 스튜디오화) 다수의 웹소설 원작 웹툰 이 성공하면서 웹툰 제작에 대규모 자본이 투입되고, 분업을 통해 빠른 시간 안에 콘텐츠가 생산되는 제작의 스튜디오화가 발생

- (현지 작가 발굴) 해외 현지의 작가가 웹툰 플랫폼의 공모전 등을 통해 웹툰 플랫폼 으로 유입하고 웹툰 작가로 데뷔하는 현지화가 본격화

\section{다. 웹툰의 비즈니스적 가치와 유망성}

- (온라인·모바일로 전환된 콘텐츠 소비방식 변화) 콘텐츠의 소비가 온라인중심으로 이루어지고 있는 가운데 이러한 변화에 웹툰은 최적화된 양식

- (플랫폼 선점효과와 풍부한 제작 자원) 앱 시장을 중심으로 플랫폼 선점의 형태를 띠고 있어 네트워크 효과가 발생하고 있고, 많은 작가와 작품들이 누적되면서 후발 주자에 대한 진입장벽을 형성

- (MZ 세대가 선호하는 디지털 콘텐츠) MZ세대는 편하게 즐길 수 짧은 호흡의 디지 털 콘텐츠를 선호하는 경향이 있는데 웹툰은 짧은 호흡에 흥미있는 요소를 집약적 으로 담는 방식을 취함

- (원천 콘텐츠로의 가치와 OSMU 용이성) 웹툰에는 참신한 소재와 창의력 있는 이야 기가 축적되어 있으며 영상화에 있어서 초기 콘티의 역할까지 가능해 활용이 용이 


\section{라. 소결: 웹툰산업 현황 분석의 시사점}

- 웹툰산업의 한계점

- (아직 해외시장에서는 진출초기인 도입기) 웹툰산업은 국내에서는 성장기에 다 다랐지만 해외 시장에서는 아직 인지도와 도입기에서 성장기 초기 정도에 해당 - (부족한 산업적 면모) 관련 산업의 통계나 자료가 부족하고 네이버, 카카오 등 대형 플랫폼 기업 주도로 기업의 필요에 따라 산업이 형성된 경향이 나타남 - (불법유통 취약) 웹툰산업 매출에 큰 타격을 주고 있는 불법 복제와 유통은 정부 및 외교적 차원에서 공조를 통해 해결해야 할 근본적 과제

- 웹툰산업의 경쟁력

- (새로운 디지털 콘텐츠로의 높은 가능성) 디지털 중심의 콘텐츠 소비 패턴을 고 려했을 때 웹툰은 새로운 디지털 콘텐츠나 스낵컬처로 각광을 받을 가능성이 높음

- (IP로의 높은 비즈니스 가치) 웹툰 원작 콘텐츠의 성공시례가 지속적으로 발생 되고 있으며 웹툰산업은 영상화나 게임화 등 IP 활용이 유리한 장르

- (축적된 비즈니스 노하우) 국내 웹툰산업은 20년이 가까운 역사 속에서 다양한 비즈니스 경험을 습득했으며 다양한 유료모델 시도를 통해 유의미한 성과들을 발생시킴

[그림 4] 웹툰산업 현황 분석 시사점: 웹툰산업의 경쟁력과 한계점

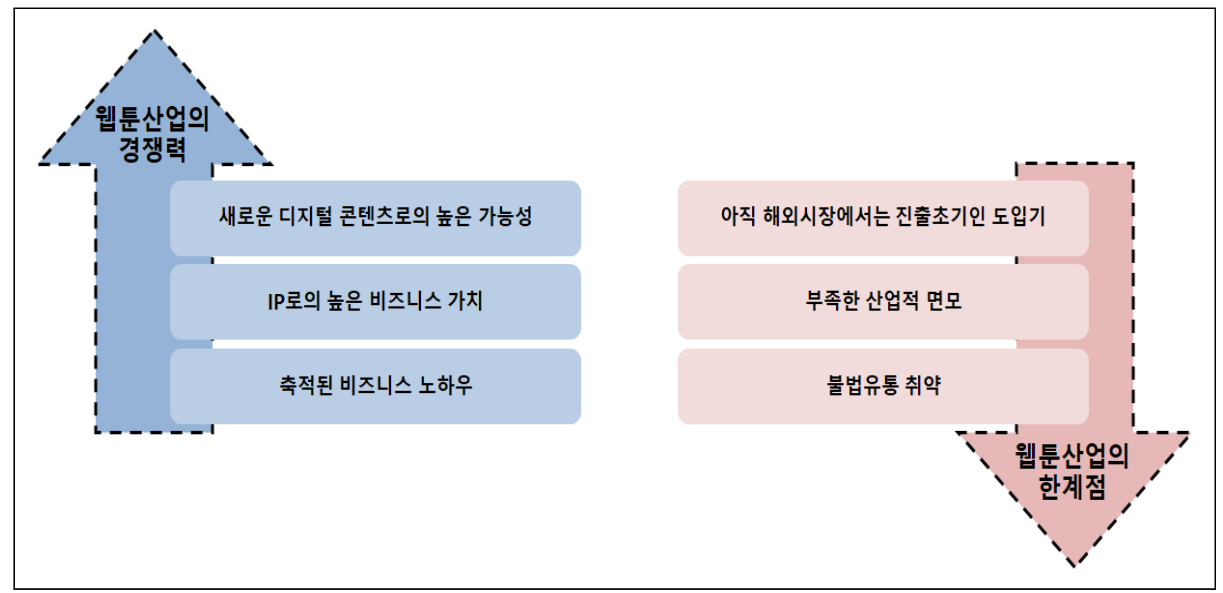




\section{3. 해외 주요국의 디지털 만화 시장 및 웹툰산업 진출 현황}

\section{가. 주요국의 디지털 만화산업 현황}

- 만화산업은 전 세계적으로 답보상태

- 일본의 만화시장은 인쇄 출판 시장이 매년 하락세를 기록하고 있는 반면 디지털 만화부문이 이를 상쇄하며 미약한 상승세를 이어가고 있음

- 미국도 2017년 이후로 미약한 상승세를 보이고 있음

- 영국의 만화산업은 1960 년대와 70 년대에 황금기를 누렸으나 이후로는 수축과 정체를 반복하는 중

[그림 5] 주요국의 만화산업 규모

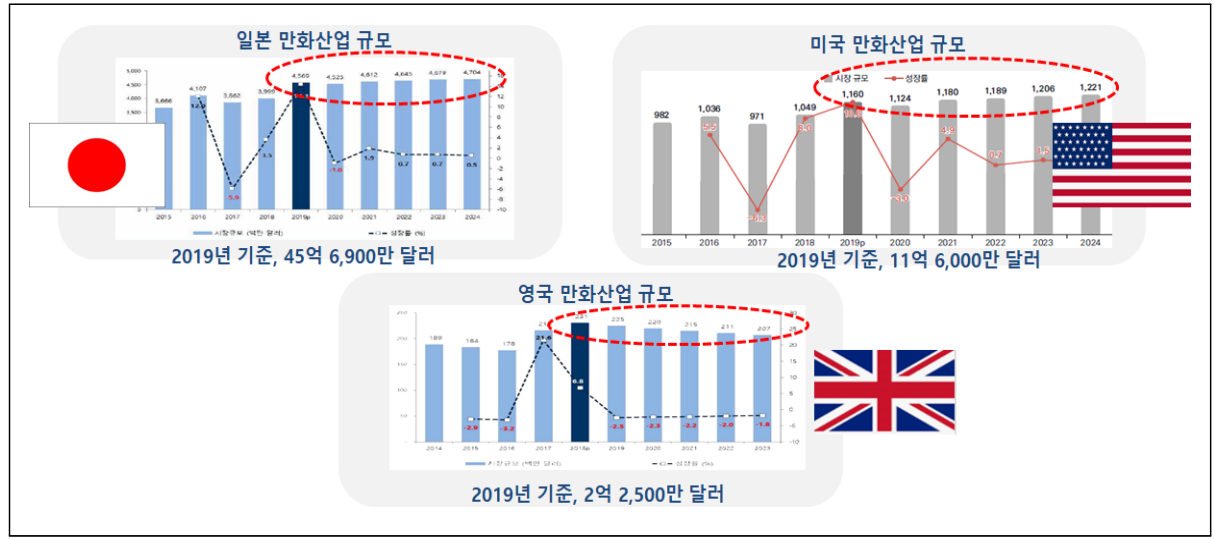

자료: PWC

- 디지털 만화시장은 미국을 제외하고 주요국에서 급격한 성장

- 일본 디지털 만화 규모는 2015년 9억 6,600만 달러에서 2019년 23억 7,800 만 달러 규모로 4 년 동안 $246 \%$ 의 급격한 성장을 기록했으며, 전체 만화시장의 절반 정도의 규모를 차지하게 됨

- 미국은 특이하게 디지털 만화 비중이 2015년 때보다도 오히려 줄어 2019년 기 준 7.4\%를 차지했는데, 이는 시도된 디지털 만화 플랫폼들이 부진한 결과

- 유럽 디지털 만화 시장의 규모와 성장률은 급격히 증가해왔으며 2013 년 1억 1,700 만 달러였다가 2015년 1억 7,600 만 달러, 2017년 2억 3,300만 달러로 4 년 동안 2 배 성장 
[그림 6] 주요국의 디지털 만화 규모

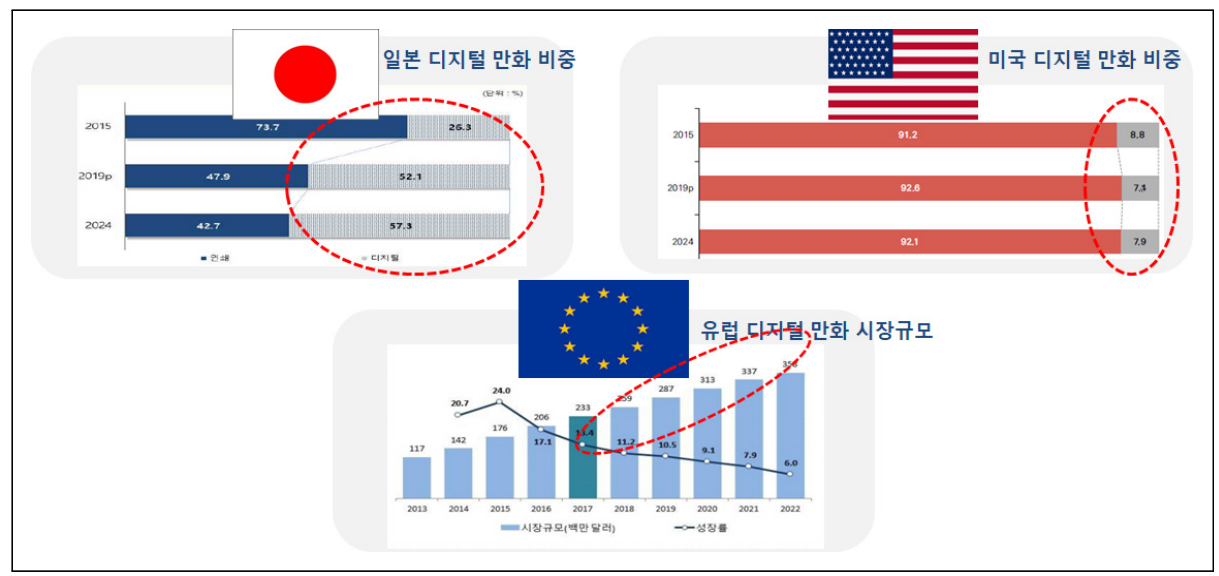

자료: PWC

\section{나. 주요국의 디지털 만화 주요 동향}

- 코로나19 여파로 높아진 만화의 디지털화 요구와 기회

- 미국은 마블 코믹스와 DC 코믹스 등 미국 오프라인 주요 만화 출판사의 공급과 유통을 독점하고 있었던 코로나19발 팬데믹의 영향으로 다이아몬드 코믹스가 유통을 중단하면서, 주요 출판사들은 디지털 퍼스트 전략을 내세우기 시작

- 일본은 반대로 코로나 19 여파로 인해 전통방식으로 작업을 하고 있던 작가들의 제작이 지연되거나 휴재되면서 신작 업데이트가 어려워지고 이로 인해 새로운 작품을 필요로 하는 독자들이 디지털 만화에 유입되기 시작

- 게다가 일본 최대 불법 만화 유통 사이트인 〈망가무라〉가 2018년 폐쇄된 이후 디지털에 익숙해진 독자층이 유료 정식 디지털 서비스로 유입

- $\mathrm{MZ}$ 세대 중심으로 디지털 콘텐츠 소비 패턴 변화: 숏텀화

- 일본은 젊은 층을 중심으로 단행본 1 권을 열독하는 것보다 출퇴근이나 이동 중 에 가볍게 만화를 소비하는 경향성이 확대

- 프랑스는 지하철 내 무료와이파이가 개통되자 10 대와 20 대를 중심으로 디지털 만화를 보는 층이 급격히 증가

- 스튜디오 제작자 이탈 조짐

- 북미의 스튜디오 체제에 있는 프리랜서들은 고용 계약과 자신이 만든 작품에 
대한 저작권을 포기해야 하는 상황으로 인해 예술가로서 정체성이 크게 위협

- 현지시장의 자생적 웹툰시장 형성 및 현지 작가 확산

- 프랑스에서는 웹툰 팩토리, 베리툰 등 한국의 웹툰 형식을 그대로 받아들여 웹 툰의 제작과 유통 문법을 따르는 플랫폼들이 발생

- 네이버 웹툰의 해외판 '도전 만화가' 인 CANVAS를 통해 발굴된 현지 작가들의 콘텐츠들이 현지에서 높은 인기순위를 기록하기 시작

\section{다. 웹툰산업의 해외진출 현황}

- 글로벌 만화 앱시장 주도

- 거의 모든 국가의 만화 앱 인기순위와 수익순위에서 한국의 웹툰 플랫폼이 최상 위 순위 석권

- 2016년부터 일본에 진출한 웹툰 플랫폼 ‘픽코마’는 일본의 구글 플레이스토어 와 애플 앱스토어에서 비(非)게임 부문 앱 매출 1 위를 차지

- 네이버 웹툰은 2020 년 구글 플레이 만화앱 분야 수익에서 103 개국 1 위를 기록 - 눈에 띠는 지점은 대형 포털업체 외에 태피툰, 리디 만타와 같은 중소 플랫폼들 도 글로벌 만화 앱시장에서 두드러진 성적을 기록 중

- 유의미한 수익성과 창출

- 초기 해외진출 시, 무료 중심으로 이루어져 수익성이 약했으나 부분유료화 등 국내에서 성공한 다양한 비즈니스 모델을 적용하여 최근 들어, 유의미한 수익 성과가 나타남

- 특히 일본에서 시장에서 수익성과의 성장성이 두드러지게 나타나고 있음(픽코 마가 2020년 기준 4,100 억 원의 거래액을, 라인망가는 2018 년 기준 2,377 억 원의 매출액을 달성)

- 글로벌 메가 히트 작품 창출

- 콘텐츠 산업의 해외진출 시에 가장 중요한 요소 중 하나는 현지에서 큰 성공을 거두는 메가히트 작품, 즉 대표적 성공사례가 발생하는 것

- 〈나 혼자만 레벨업〉은 각국 만화 플랫폼에서 인기순위 1 위를 차지하고 해외에 서의 수익만 100 억 이상을 창출하는 등 글로벌적 성공을 거두고 있음 
- 여전히 낮은 웹툰의 인지도

- 일본의 만화 브랜드인 '망가'나 미국의 만화 브랜드 '그래픽 노블'과 비교해볼 때 웹툰은 브랜드 인지도가 열세

- 해외 현지조사에서도 일반인들에게는 웹툰이라는 디지털 만화의 한 종류를 잘 알지 못했고, 소수만이 웹툰을 접한 적 있는 것으로 나타남

- 웹툰산업의 낮은 현지 시장 점유율

- 현지 디지털 만화 시장에서 웹툰산업이 차지하는 비중에 대한 정확한 통계는 없지만 현지시장 수출액과 현지시장의 만화산업 크기를 단순 비교해볼 때 그 점유율은 매우 낮은 수준

\section{라. 소결: 해외주요국 디지털 만화 및 웹툰산업 진출 현황 분석의 시사점}

- 웹툰산업의 기회점

- (만화의 디지털 전환 요구 증대) 코로나 19 의 발생으로 인해 전 세계적으로 만화 의 디지털 전환 요구가 높아졌고 그에 따라 웹툰의 성장 잠재력은 더욱 높아짐 - (중소 플랫폼의 해외진출 기회) 현재 해외시장에서의 웹툰산업은 메이저 웹툰 플랫폼이 아니더라도 해외 수익성과를 내는 시례들이 다수 발생하며 선전

- 웹툰산업의 개선점

- (낮은 글로벌 인지도와 시장 점유율) 웹툰의 잠재력은 높으나 해외에서의 인지 도나 디지털 만화 시장점유율은 아직까지는 매우 낮은 편

- (현지화 요구 수용력) 만화는 지역마다 특색이 다르기에 시장마다 다른 접근법이 필요하지만, 소재나 장르 등 아직까지는 현지화가 본격적으로 진행되지는 못함

[그림 7] 글로벌 시장에서의 웹툰산업 기회점과 개선점

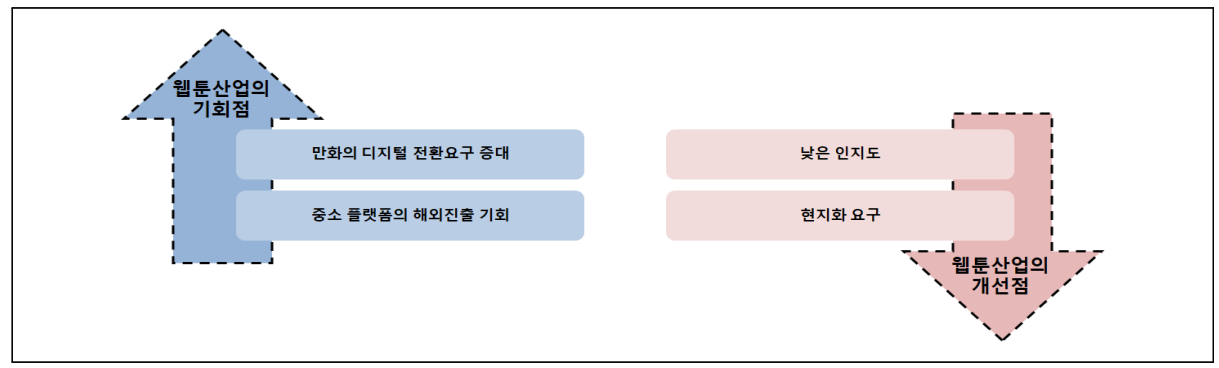




\section{4. 만화 선도국의 고도화 사례 분석}

- 웹툰산업이 고도화가 필요한 단계임을 전제로 만화선도국의 만화산업 고도화 과정 을 분석하여 고도화 요인을 도출하고 웹툰산업의 고도화 방향성 모색

- 분석 대상: 일본 만화산업, 미국 만화산업

- 방법: 현지 자료 분석 및 현지 전문가 인터뷰

- 내용: 고도화 과정 확인, 제작 시스템 및 구조 파악, 유통 시스템 및 구조 파악, 해외진출 관점에서의 시사점

〈표 1〉만화 선도국 고도화 사례분석 결과

\begin{tabular}{|c|c|c|}
\hline \multicolumn{2}{|r|}{ 시사점 } & 세부 내용 \\
\hline \multirow{2}{*}{$\begin{array}{l}\text { 제작측면 } \\
\text { 에서의 } \\
\text { 고도화 } \\
\text { 요인 }\end{array}$} & 폭넓은 시장층과 다양한 작품 & $\begin{array}{l}\text { - 일본은 독자의 나이, 성별, 작품의 주제 등으로 촘촘히 세분화한 } \\
200 \text { 종이 넘는 만화 잡지가 구성 } \\
\text { - 미국 역시 스튜디오화의 획일화를 극복하는 과정에서 마블 메소 } \\
\text { 드 방식이 등장하는 등 다양한 세계관과 장르들이 형성 }\end{array}$ \\
\hline & 편집부(editor)의 역할 정교화 & $\begin{array}{l}\text { - 일본 만화제작 시스템의 가장 큰 특징 중 하나는 전문 편집자가 } \\
\text { 체계적으로 양성되어 제작 시에 작품의 질을 높이는데 크게 기여 } \\
\text { 한다는 점 } \\
\text { - 미국의 편집자는 전체 프로젝트를 총괄하고 관리하는 감독의 역 } \\
\text { 할을 수행 }\end{array}$ \\
\hline \multirow[t]{2}{*}{$\begin{array}{l}\text { 유통측면 } \\
\text { 에서의 } \\
\text { 고도화 } \\
\text { 요인 }\end{array}$} & 글로벌 이벤트 적극 활용 & $\begin{array}{l}\text { - 일본은 이미 1970년대 중반부터 코믹 마켓을 열어 만화의 창작 } \\
\text { 과 소비, 유통이 프로 작가와 전문 출판사의 상업적 영역뿐 아니 } \\
\text { 라 아마추어 독자들이 모여 산업과 소비를 활성화 } \\
\text { - 또한 해외의 글로벌 만화 이벤트에 자본을 지원하여 전 세계적인 } \\
\text { 행사로 발전시키고 그 이벤트에 많은 지분을 차지하며 글로벌 영 } \\
\text { 향력을 강화 } \\
\text { - 미국은 주요 도시에서 주요 미국 만화 사업자들을 중심으로 글로 } \\
\text { 벌 만화 행사를 개최하고 이들 마켓시장을 주도 }\end{array}$ \\
\hline & 미디어 믹스, IP 확장의 발전 & $\begin{array}{l}\text { - 일본은 기획단계에서부터 TV애니메이션과 드라마 제작을 염두하 } \\
\text { 며 미디어 믹스가 일반적인 비즈니스 모델로 정착 } \\
\text { - 미국도 대규모 투자를 통한 만화 콘텐츠의 IP를 활용한 영상화로 } \\
\text { 정교한 비즈니스 모델이 구축 }\end{array}$ \\
\hline
\end{tabular}




\section{5. 웹툰산업 해외진출 정책 분석 및 전문가 인터뷰}

\section{가. 웹툰산업 해외진출 지원 관련 정책 분석}

- 상위 계획 분석: 만화산업 발전 계획(2019)

- '꿈이 커가는 한국만화, 새로운 한류의 중심'이라는 비전 아래 산업 경쟁력 강 화, 신시장 확대 및 수요 창출, 공정환경 조성 및 제도 개선 등 3가지의 정책 방향을 제안

- 이중 해외진출 지원은 두 번째 전략방향인 신시장 확대 및 수요창출이 해당되며 만화를 '신한류 콘텐츠로 도약 시키기 위해 2018년에 0.4억 달러 수준이었던 수출액을 2023년까지 1억 달러로 끌어올리는 것을 목표로 설정

- 주요기관 세부사업 분석

\begin{tabular}{|c|c|c|c|}
\hline 기능 & 사업명 & 사업수행기관 & 지원 규모 \\
\hline \multirow{4}{*}{$\begin{array}{l}\text { 홍보, } \\
\text { 프로모션 }\end{array}$} & 만화 IP 해외 피칭 지원 & 한국콘텐츠진흥원 & 6.8억, 행사별 10개사 \\
\hline & $\begin{array}{c}\text { 기업 자율형 만화 해외 프로모션 } \\
\text { 지원 }\end{array}$ & 한국콘텐츠진흥원 & $\begin{array}{l}\text { 4억, 총 8개사 } \\
\text { (기업당 5천만원) }\end{array}$ \\
\hline & $\begin{array}{c}\text { 만화 해외마켓 한국공동관 참가 } \\
\text { 지원 }\end{array}$ & 한국콘텐츠진흥원 & 3.5억, 10 개사 내외 \\
\hline & 해외 프로모션 지원 사업 & 한국만화영상진흥원 & $\begin{array}{c}3.6 \text { 억원, } \\
\text { 프로모션 9개 과제, 상담회 12개사 }\end{array}$ \\
\hline 번역 & 수출작품번역지원 & 한국만화영상진흥원 & 6억, 70개과제(과제당 850만원) \\
\hline $\begin{array}{c}\text { 플랫폼 } \\
\text { 구축/운영 } \\
\text { 지원 }\end{array}$ & $\begin{array}{c}\text { 만화 해외 플랫폼 구축 } \\
\text { 및 운영 지원 }\end{array}$ & 한국콘텐츠진흥원 & 최대 3억원, 4개 내외 과제 \\
\hline $\begin{array}{l}\text { 국제 } \\
\text { 교류 }\end{array}$ & $\begin{array}{c}\text { 한국만화 해외전시 및 } \\
\text { 만화 교류 }\end{array}$ & 한국만화영상진흥원 & 3.7억 \\
\hline
\end{tabular}

- 시사점: 기존 정책의 한계점

- (규모의 확대 필요) 해외진출이 본격화 되면서 해외진출 지원의 수요가 증대됨 에 따라 번역, 프로모션 등 기존사업의 규모를 확대할 필요가 있음

- (장기적 관점의 지원 필요) 해외진출과정에서 시장이 해결해 주지 못하는 시장 실패의 기능이 장기적으로 요구됨 


\section{나. 전문가 및 업계 의견 조사}

- 현황을 구체적으로 파악하고 실질적인 해외진출 진흥 방안을 도출하기 위해 전문 가 및 업계 관계자 자문회의를 진행

- 기간: 2021년 4월 20일에서 2020년 7월 30일까지

- 자문회의 차수: 10 차에 걸쳐서 전문가 자문회의 진행

- 대상: 웹툰 업계전문가(플랫폼, 에이전시, 스튜디오 등), 웹툰 작가, 웹툰 관련 학계 전문가, 연구계 및 관계 전문가(한국콘텐츠진흥원, 한국만화영상진흥원 등 웹툰 해외진출 사업 담당자, 협회)

- 방법: 구조화된 질문지 또는 회의 안건 제시를 통한 토론 진행, 온라인 원격회의 와 현장회의 병행

〈표 2〉전문가 및 업계 의견 조사 결과

\begin{tabular}{|c|c|}
\hline 시사점: 주요 의견 & 세부 내용 \\
\hline $\begin{array}{c}\text { 현재 웹툰의 해외진출은 도입기 } \\
\text { 단계에 불과 }\end{array}$ & $\begin{array}{l}\text { - 만화시장 전체로 넓혀서 보면 웹툰산업은 전세계 만화 규모에 비해 아직 낮 } \\
\text { 은 수준 } \\
\text { - 게다가, 무료로 제공하고 있는 방식이 대다수이다 보니 아직 수익화 되기까 } \\
\text { 지는 많은 과정이 필요하며, 현재는 수익화 전에 웹툰 형식을 알리고 많이 } \\
\text { 활용할 수 있도록 하는 홍보가 필요한 단계 }\end{array}$ \\
\hline $\begin{array}{c}\text { 통계 및 } \\
\text { 해외정보의 절대적 부족 }\end{array}$ & $\begin{array}{l}\text { - 웹툰 해외진출을 시도하고 있는 유통사들에게는 해외진출 시 해당 현지의 } \\
\text { 정보가 부족하는 것을 해외진출 시 가장 큰 애로사항 중 하나 } \\
\text { - 직접 그 시장에 부딪혀보거나 지인을 통한 정보획득 외에는 현지의 만화시 } \\
\text { 장정보를 알 수 없어 정보의 한계에 부딪힐 경우가 많음 }\end{array}$ \\
\hline $\begin{array}{c}\text { 웹툰 브랜드의 글로벌 확장과 } \\
\text { 국제 표준화 시도 필요 }\end{array}$ & $\begin{array}{l}\text { - 해외에서 파트너를 구하거나 계약을 진행할 때 가장 힘든 시행착오 중에 하 } \\
\text { 나는 웹툰의 인지도가 낮아 웹툰 자체를 설명하는 것 } \\
\text { - 웹툰이 전 세계적인 디지털 만화로 자리 잡기 위해 필요한 기반 요소 중 } \\
\text { 하나가 규격과 표준을 일원화하는 것이 필요 }\end{array}$ \\
\hline $\begin{array}{c}\text { 글로벌적 } \\
\text { 인식과 체계 마련 }\end{array}$ & $\begin{array}{l}\text { - 국내의 차원을 넘어서 해외에까지 그 영향력을 넓히는 과정에서 국제차별에 } \\
\text { 대한 인식과 인류 보편적 관념 및 윤리의식에 대한 인식 개선이 필요한 시점 } \\
\text { - 높아진 위상에 따라 공정 거래 환경이나 건전한 생태계 조성하는 등 법제도 } \\
\text { 적인 체계가 구축 필요 }\end{array}$ \\
\hline
\end{tabular}




\section{6. 웹툰산업 해외진출 진흥 방안}

\section{가. 정책 기본방향 설정}

- 웹툰산업 해외진출 진흥 정책의 기본 틀

- Warwick(2013)의 산업정책의 분류를 적용하여 웹툰산업의 해외진출 진흥 정 책방향을 수평적 정책과 수직적 정책으로 나누어서 접근

- 수평적 정책은 웹툰산업의 저변의 확장하고 기반을 마련하는 차원의 정책방향

- 수직적 정책은 해외진출 관점에서 홍보, 프로모션, 네트워킹 지원, 현지화 지원 과 같이 직접적으로 해외진출을 지원하는 정책

- 폭이 좁은 상태인 현재(A)에서 목표지점(B: 글로벌 만화산업 선도)까지 도달하 기 위해서는 다양하고 질 높은 콘텐츠들이 다양하게 발생되고 산업의 면모를 갖춰야 하며(수평적 발전) 동시에 글로벌 경쟁력이 강화(수직적 발전)되어야 함

[그림 8] 웹툰산업 해외진출 진흥 정책의 두 축

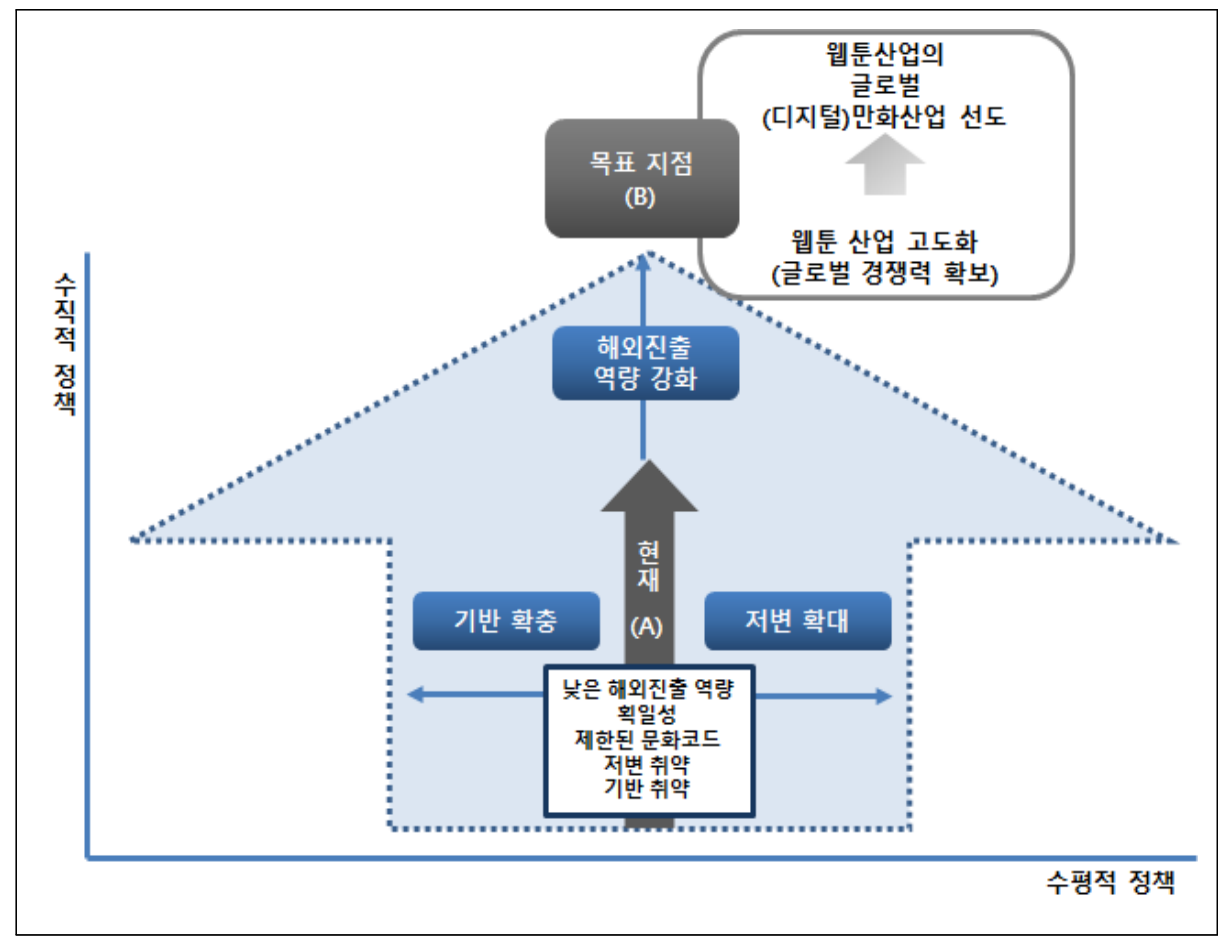


- 종합정리 및 개선점 도출

- 앞서 정리한 분석들의 시사점을 종합하고 정리하여 문제점 및 개선점 도출

- (제도적/산업적 기반 부족) 해외진출에서 도입기에 불과하다는 점과 맥락을 같 이 하는 지점이며, 플랫폼 사업자들이 주도적으로 산업을 형성하는 과정에서 발 생한 문제점

- (획일성/저변 부실) 다수의 인기작들이 일부 장르에 편중되고 소재도 비슷한 획 일화와 편집 및 기획 시스템 부족 등 부실한 환경의 개선이 필요

- (현지화) 소재와 기본적인 정서, 문화적 코드 등 현지시장 정보 파악, 고급 번역 등 현지화의 어려움이 존재

- (글로벌 경쟁력) 콘텐츠 자체의 경쟁력뿐 아니라 플랫폼 경쟁력까지 글로벌 수 준으로 높여야 하는 과제가 주어짐

[그림 9] 종합정리 및 개선점 도출 과정

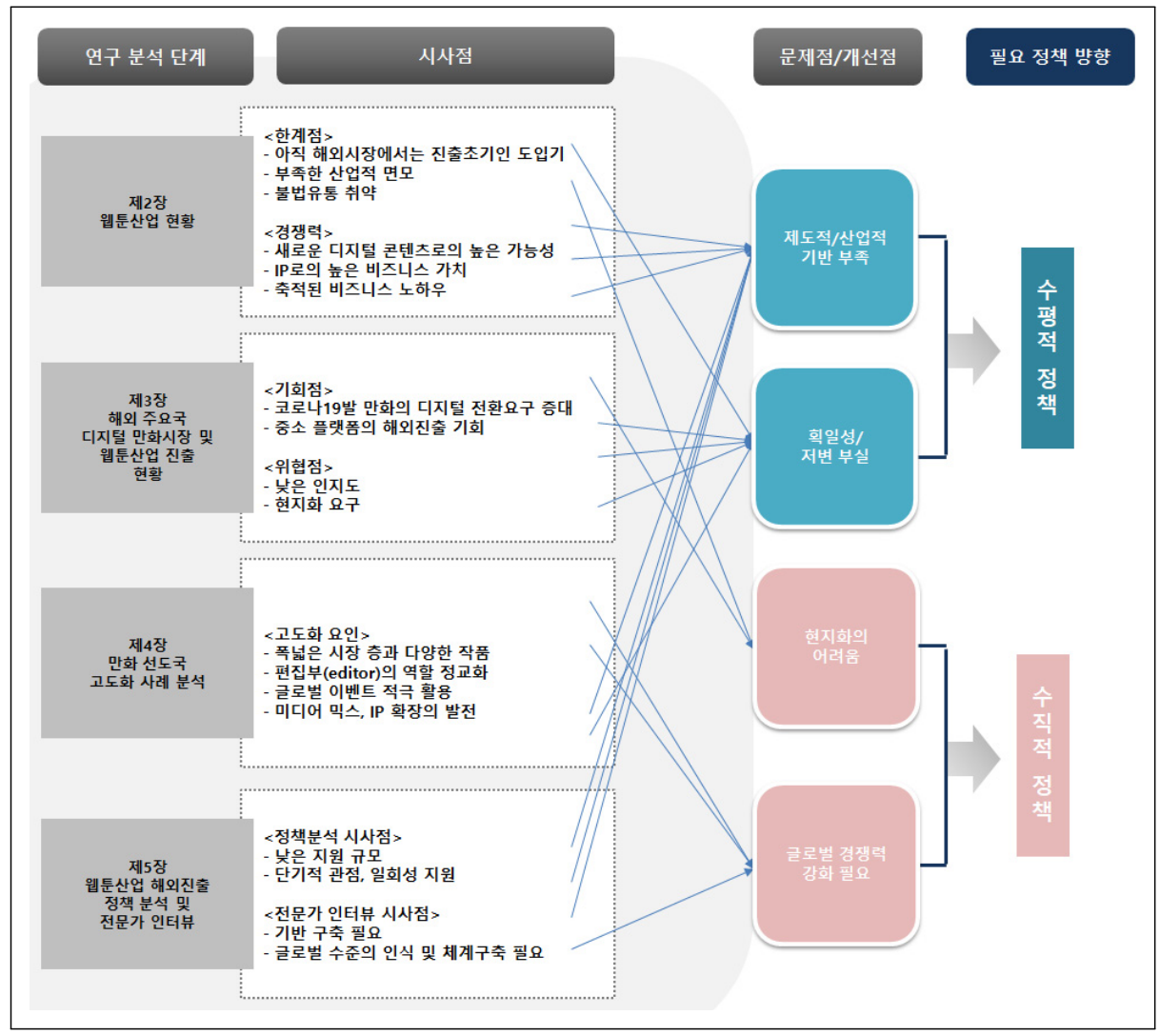




\section{나. 정책 방향과 방안}

- 핵심 문제점 및 개선점을 극복하기 위한 정책방안들을 도출하고 이들을 체계적 으로 정리하기 위한 정책방향을 설정

- 웹툰산업의 다음 페이지를 넘어간다는 의미로, 웹툰 용어인 SCROLL-UP을 핵 심 단어로 설정하고 각 단계별로 이니셜에 따라 정책방향을 구성

- 최종정책 방향으로 기반 확충(Set-up), 저변 확대(Cover-up), 인력양성과 교육 (Raise-up), 시장 개척 및 수요발굴(Open-up), 글로벌 경쟁력 강화 (Lead-up), 혁신 환경조성(Level-up)으로 설정하고 세부 방안 마련

[그림 10] 정책방향과 방안

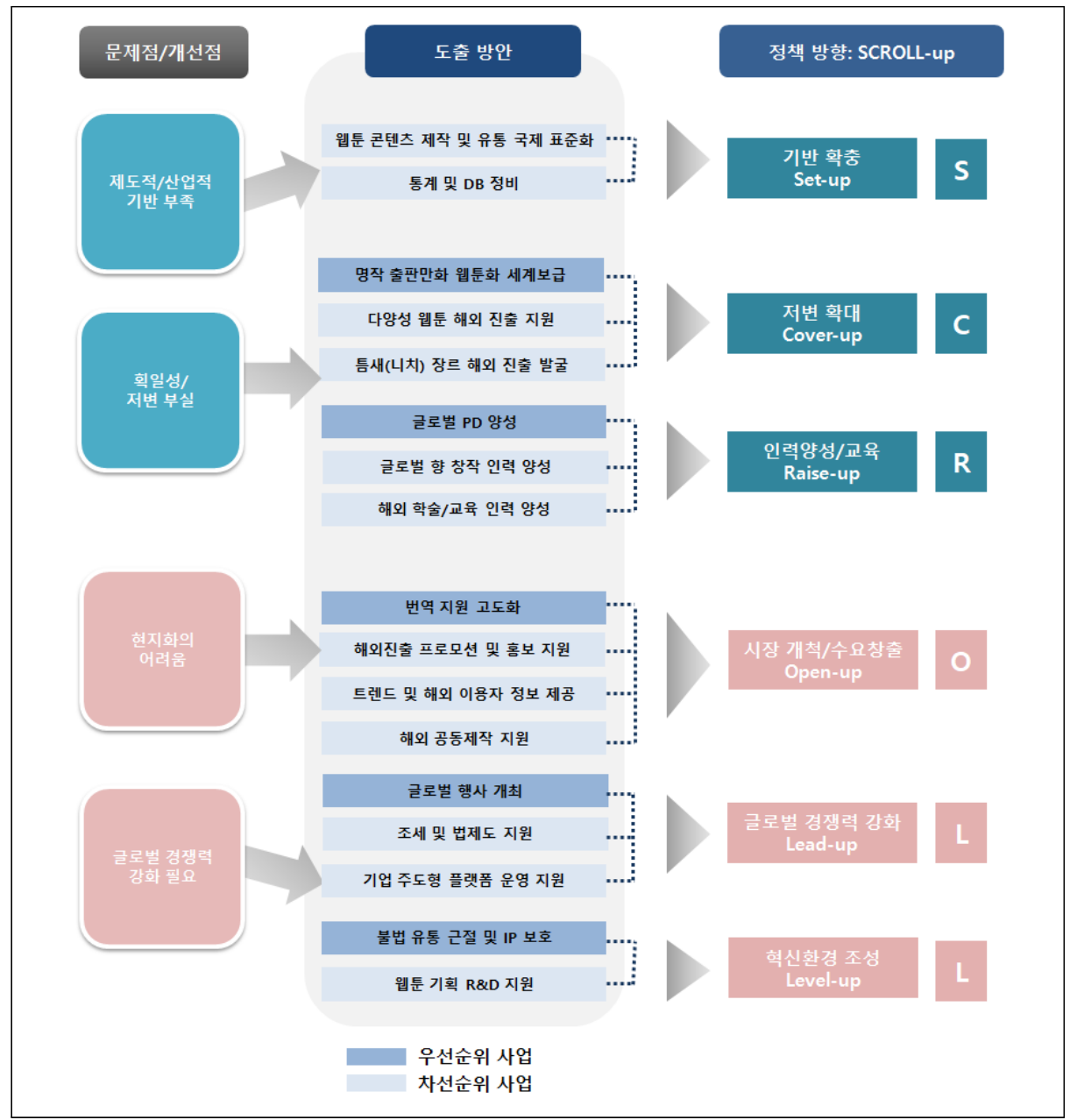




\section{다. 정책적 제언 및 결론}

- 해외진출에 있어서 웹툰산업은 아직 도입기에 불과하다는 것을 정책적으로도 직시 해야 함

- 새로운 플랫폼 자체와 그에 해당하는 제작, 유통, 소비 문법을 수출하여 디지털 콘텐츠 시장을 선점해야하는 조금 더 적극적인 수출방식이 요구되며 기존의 콘텐 츠 수출지원과 다른 접근의 정책방향이 필요

- 장기적인 관점에서 웹툰산업의 글로벌 경쟁력을 강화하기 위해서는 산업자체의 저 변과 기반의 폭을 넓혀야 함 


\section{목차}

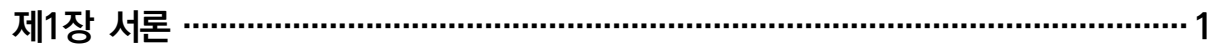

제1절 연구 배경 및 목적 3

1. 연구 배경 3

2. 연구 목적 6

제2절 연구범위 및 방법 $\quad 8$

1. 연구 범위 8

2. 연구 방법 9

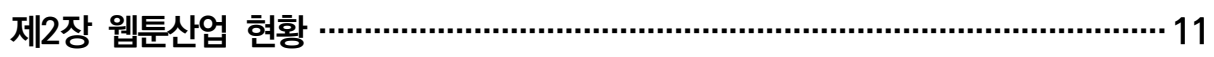

제1절 웹툰산업 개요 13

1. 웹툰 및 웹툰산업의 정의와 범위 13

2. 웹툰 및 웹툰산업의 특징 18

3. 웹툰산업의 발전과정 22

제2절 웹툰산업 현황 $\quad 27$

1. 국내 웹툰산업 규모 $\quad 27$

2. 웹툰산업 주요 이슈 및 트렌드 28

제3절 웹툰산업의 사업방식 35

1. 웹툰의 비즈니스적 가치와 유망성 35

2. 웹툰산업의 비즈니스 모델 39

제4절 소결 $\quad 56$

1. 웹툰산업의 한계점 56

2. 웹툰산업의 경쟁력 $\quad 57$ 
제3장 해외 주요국의 디지털 만화 시장 및 웹툰산업 진출 현황 ……..................5 59

$\begin{array}{ll}\text { 제1절 일본 현황 } & 61\end{array}$

1. 일본 디지털 만화 시장 현황 61

2. 웹툰산업의 일본 진출 현황 67

제2절 미국 현황 $\quad 70$

1. 미국 디지털 만화 시장 현황 70

2. 웹툰산업의 미국 진출 현황 74

$\begin{array}{ll}\text { 제3절 유럽 현황 } & 78\end{array}$

1. 유럽 디지털 만화 시장 현황 78

2. 웹툰의 유럽 진출 현황 81

제4절 동남아시아 현황 84

1. 동남아시아 디지털 만화 시장 현황 84

2. 웹툰산업의 동남아시아 진출 현황 87

제5절 소결 $\quad 89$

1. 해외 현지시장의 기회점 89

2. 해외 현지시장 진출에서의 위협점 90

제4장 만화 선도국의 고도화 사례 분석 ……........................................................93

제1절 사례분석 개요 95

1. 사례분석의 의의 95

2. 사례분석의 목적과 대상 96

3. 사례분석의 방법과 내용 96

제2절 일본 만화산업의 고도화 모델 97

1. 고도화 과정 97

2. 제작 시스템 및 구조 101

3. 유통 시스템 및 구조 105

4. 해외진출 관점에서의 시사점 109

제3절 미국 만화산업의 고도화 모델 111

1. 고도화 과정 111

2. 제작 시스템 및 구조 119

3. 유통 시스템 및 구조 125

4. 해외진출 관점에서의 시사점 129 
1. 제작 측면에서의 고도화 요인 132

2. 유통 측면에서의 고도화 요인 133

제5장 웹툰산업 해외진출 정책 분석 및 전문가 인터뷰 ………………………... 135

제1절 웹툰산업 해외진출 정책 분석 137

1. 상위 계획 분석 137

2. 주요기관 웹툰산업 해외지원 사업 현황 138

3. 웹툰산업 해외진출 지원 관련 사업 정리 146

제2절 전문가 및 업계 의견 조사 148

1. 전문가 및 업계 관계자 자문회의 개요 148

2. 전문가 및 업계 관계자 자문회의 결과 149

제3절 소결 154

1. 웹툰산업 해외진출 지원 정책의 한계점 154

2. 업계 및 전문가 인터뷰 시사점 155

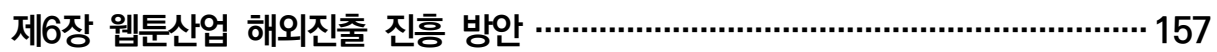

제1절 정책 기본 방향 159

1. 기본 방향 설정 과정 159

2. 정책 방향 및 방안 도출 163

제2절 세부 정책 방안 165

1. 기반 확충(Set-up) 165

2. 저변 확대(Cover-up) 168

3. 인력 양성/교육(Raise-up) 172

4. 시장 개척/수요 창출(Open-up) 177

5. 글로벌 경쟁력 강화(Lead-up) 184

6. 혁신환경 조성(Level-up) 188

제3절 정책적 제언 및 결론 193

참고문헌 / 195

ABSTRACT / 199 


\section{표 목차}

〈표 2-1〉 만화진흥에 관한 법률에 나타난 디지털만화의 정의 13

〈표 2-2〉 웹툰산업 주체 15

〈표 2-3〉 주요 웹툰 플랫폼 16

〈표 2-4〉국내 주요 웹툰 에이전시 현황 17

〈표 2-5〉 웹툰 플랫폼의 최근 해외진출 성과 25

〈표 2-6〉 국내 웹툰산업 규모 27

〈표 2-7〉 웹툰의 IP 확장 사례 29

〈표 2-8〉 네이버 웹툰 미국/스페인 top 10에서의 현지작품 강세 33

〈표 2-9〉 콘텐츠 장르별 글로벌 주도 플랫폼 35

〈표 2-10〉 웹툰의 유료화 모델 43

〈표 3-1〉 일본의 디지털 만화 사업자 현황 64

〈표 3-2〉 프랑스 웹툰 플랫폼 현황 81

〈표 3-3〉 인도네시아 및 태국 현지 웹툰 플랫폼 86

〈표 3-4〉 인도네시아 디지털 만화 서비스 이용 순위 87

〈표 3-5〉태국에 진출한 주요 웹툰 플랫폼 88

〈표 4-1〉 고도화 사례분석 개요 96

〈표 4-2〉 미국 만화산업의 고도화 단계 112

〈표 4-3〉 제작과정의 분업화 120

〈표 5-1〉 신시장 확대 및 수요 창출을 위한 세부 전략 방안(만화산업 발전 계획, 2019) 137

〈표 5-2〉각 기관별 웹툰산업 해외진출 지원 사업 147

〈표 5-3〉 전문가 및 업계 관계자 명단 148

〈표 6-1〉 글로벌 PD 과정 필요 양성부문 173 


\section{그림 목차}

[그림 1-1] 연구 배경 및 필요성 6

[그림 1-2] 연구의 수행방법 및 과정 10

[그림 2-1] 만화의 하위 범위와 웹툰 14

[그림 2-2] 세로스크롤과 컬러를 통한 극적 효과 18

[그림 2-3] AR 기술을 적용한 〈폰령〉 (위), Al 기술을 적용한 〈마주쳤다〉 (아래) 21

[그림 2-4] 국내 및 해외에서의 웹툰산업의 수명주기 상 현재 위치 26

[그림 2-5] 연간 웹툰 생산량 및 누적량 28

[그림 2-6] (좌)마블의 "MCU 세계관"과 (우)네이버웹툰 "Super String 세계관" 29

[그림 2-7] 인스타툰(좌)과 텀블벅의 웹툰 크라우드 펀딩(우) 30

[그림 2-8] 불법 웹툰 유통사이트의 페이지 뷰수 추이 31

[그림 2-9] 웹소설 기반 스튜디오 시스템으로 만들어진 웹툰 예시 32

[그림 2-10] 글로벌 디지털 만화 시장 규모 36

[그림 2-11] 네이버 웹툰 국가별 구독자 연령 비중 37

[그림 2-12] 웹툰산업 비즈니스모델 발전 과정 39

[그림 2-13] 포털 다음의 초기 웹툰서비스 40

[그림 2-14] 포털 네이버의 초기 웹툰서비스 41

[그림 2-15] 네이버 웹툰 배너 광고 집행 프로세스 44

[그림 2-16] 네이버 웹툰의 배너 광고 상품 44

[그림 2-17] 네이버 브랜드 웹툰/PPL 집행 프로세스 45

[그림 2-18] 네이버 웹툰 전체 2위까지 달성한 유진투자증권의 브랜드 웹툰 45

[그림 2-19] 네이버웹툰과 카카오웹툰의 가상화폐 리워드형 광고 46

[그림 2-20] 독자들에게 긍정적 호응을 얻은 굽네치킨의 조석 〈마음의 소리〉 PPL 47

[그림 2-21] 웹툰을 원작으로 제작된 영화 〈은밀하게 위대하게〉,〈이끼〉, 〈이웃사람〉 51

[그림 2-22] 조석의 〈마음의 소리〉 라이선싱을 활용해 출시한 제품 51

[그림 2-23] 웹소설에서 웹툰, 드라마까지 장르가 확장된 〈김비서가 왜 그럴까〉 52

[그림 2-24] 웹툰 제작사 와이랩이 구축한 IP 세계관 '슈퍼스트링'의 타임라인 54

[그림 3-1] 일본 만화산업 규모 61 
[그림 3-2] 일본만화 시장에서 디지털 만화가 차지하는 비중 변화

[그림 3-3] 일본 비게임 부문 앱 매출 순위(1위 픽코마, 2위 라인망가) 68

[그림 3-4] 미국 만화산업 규모 70

[그림 3-5] 미국만화 시장에서 디지털 만화가 차지하는 비중 변화 71

[그림 3-6] 미국 만화 시장의 출판사별 시장 점유율 72

[그림 3-7] 구글 플레이스토어 만화 부문 인기 및 수익 차트(2021년 8월 18일 기준) 75

[그림 3-8] 네이버 웹툰 사업 지배구조도(단위: \%) 77

[그림 3-9] 영국 만화시장 규모 및 성장률 78

[그림 3-10] 유럽 디지털 만화 시장 규모 및 전망 79

[그림 3-11] 유럽 디지털 만화 시장 규모 및 전망 80

[그림 3-12] 성별과 나이에 따른 웹툰 구독과 인식(프랑스) 83

[그림 3-13] 인도네시아 만화시장 규모 및 성장률 84

[그림 3-14] 태국 만화시장 규모 및 성장률 85

[그림 4-1] 일본 만화 시장 구조와 규모 102

[그림 4-2] 일본 서적 유통 시스템 105

[그림 4-3] 2016 2020년 미국 만화 유통 채널별 시장 점유율 변화 추이 112

[그림 4-4] 미국 만화 제작 과정 120

[그림 5-1] 2018년 일본에서 진행된 K-Story \& Webtoon in Japan에서 일본 현지 바이어와 상담하고 있는 국내 관계자들 139

[그림 5-2] 2018년 중국 제 25회 베이징국제도서전에서 진행된 만화·웹툰 작가

시연회 140

[그림 5-3] 2020년 수출작품 번역 지원사업 선정작 〈전지적 짝사랑 시점〉 142

[그림 5-4] 2019년 이탈리아 ‘웹툰의 세계로 초대합니다

(BENVENUTI NEL MONDO DEL WEBTOON)' 만화 전시 개막식 143

[그림 5-5] 해외 프로모션 지원사업을 통해 해외 수출을 확정지은 락킨코리아의

웹툰 IP 144

[그림 6-1] 윕툰산업 정책의 두 축 160

[그림 6-2] 종합 정리 161

[그림 6-3] 정책 방향 163 
웹툰산업 해외진출 진흥 방안 연구

제1장

서론 



\section{제1절 연구 배경 및 목적}

\section{1. 연구 배경}

\section{가. 웹툰산업의 성장}

국내에서 발생한 새로운 디지털만화 방식인 웹툰은 '콘텐츠의 디지털화' 바람에 가장 적극적으로 적응하고 진화하면서 하나의 디지털 만화 장르로 산업을 형성하였으며, 국내 에서 점점 해외로 산업적 성장을 확대하고 있다. 이로 인해 전 세계적으로 만화산업 규 모가 축소되고 있는 상황에도 국내 만화산업은 웹툰산업의 꾸준한 성장에 힘입어 2017 년에 시장규모 1 조원을 돌파하였고, 최근 10 년간 수출액은 $880 \%$ 나 증가1)하였다. 2010년대 중반부터 본격적으로 진출한 한국 웹툰 플랫폼의 해외진출 성과도 최근 들어 그 결실들이 보이기 시작하였다. 글로벌 데이터조사업체 앱애니(App Annie)에 따르면 2020년을 기준으로 네이버 웹툰은 103 개국에서 구글플레이 앱마켓 만화부분에서 수익 1 위를 기록하였고, 카카오의 웹툰 플랫폼 픽코마는 일본 앱시장 비게임 부문 전체에서 월간 매출 1 위를 차지하기도 하였다. 단일 콘텐츠로도 카카오 페이지의 〈나 혼자 레벨 업>이 100 억 이상의 해외 수익을 거두면서 웹툰의 해외진출 이후 가장 큰 성공을 거둔 메가 히트 사례를 만들기도 하였다.

직접적인 효과뿐 아니라 영화, 드라마, 게임 등 웹툰 콘텐츠를 원작으로 활용하고 성 공함으로써 원천 콘텐츠로의 글로벌 위상도 높아졌다. 특히 윕툰 IP를 기반으로 제작한 드라마와 영화들이 글로벌 OTT 플랫폼에서 전 세계적으로 흥행함에 따라 원천 IP로의 가치가 높아지고 콘텐츠의 원천 재료로 글로벌한 관심이 증대되고 있다. 예를 들어 넷플 릭스에 따르면 웹툰을 원작으로 제작한 영화 〈승리호〉는 26개국 넷플릭스 순위에서 1 위 를 차지를 차지했으며, 2021년 4월 기준으로 2,600만 가구가 시청2)한 것으로 나타났

1) 만화산업 발전 계획(2019)

2) 2021년 4월 기준, 넷플릭스 보도자료 
다. 또 〈이태원 클라쓰〉, 〈스위트 홈〉과 같은 웹툰 원작의 드라마들도 넷플릭스를 통해 여러 국가에서 인기 콘텐츠로 주목을 받게 되고 이에 따라 전 세계에서 웹툰 IP에 대한 관심과 구매요청이 활발해지는 계기를 마련하였다.

\section{나. 여전히 낮은 글로벌 인지도와 디지털 만화시장 점유}

웹툰산업이 글로벌 만화 앱시장을 선도하며 그 영향력이 높아진 것은 사실이지만, 전 체 글로벌 만화시장으로 관점을 확대해서 살펴보면, 글로벌 인지도나 디지털만화 시장 점유율은 아직도 낮은 수준이다. 단적으로 웹툰을 일본 만화인 망가나 미국 만화인 그래 픽 노블과 비교하면 글로벌 만화시장에서 차지하는 절대적 규모가 작고 인지도도 낮다. 게다가 웹툰 플랫폼 중심으로 무료 유통이 확산되고 있다 보니 MAU(Monthly Activity User, 월간 이용자 수)와 같은 노출도 성과는 높아진 반면 실질적 산업 성과인 수익성은 상대적으로 낮다는 한계도 드러나고 있다.

국내에서의 웹툰산업은 높은 인지도를 지니고 있으며 성장기를 이미 거치고 있는 반 면 웹툰산업의 해외진출은 아직 도입기에서 성장기로 넘어가고 있는 과도기를 거치고 있다. 따라서 본격적으로 성장기에 안착하기 위해서는 시장 고도화와 콘텐츠 현지화라는 과제가 주어진 상황이다. 게다가 여전히 글로벌 유통 과정에서의 불법복제 문제가 극복 되지 못했으며 최근에는 폭력성·선정성 논란이 일고 있는 등 웹툰이 디지털 만화의 글로 벌 표준(global standard)으로 가기에 넘어야할 산들이 많은 상황이다.

\section{다. 새로운 방식(장르와 플랫폼 자체를 수출)에 맞는 정책 요구}

콘텐츠산업의 디지털화로 인해 콘텐츠의 해외진출이 플랫폼을 중심으로 이루어지고 있으며 국내 콘텐츠 산업의 해외진출도 해외의 글로벌 플랫폼 의존도가 높아졌다. 콘텐 츠 해외진출 지원의 방식도 이러한 환경에서 국내 콘텐츠 사업자들이 어떻게 효과적으 로 진출이 이루어지도록 하고, 공정거래 환경을 만들지 등 해외의 플랫폼 주도환경에서 의 대응을 위한 정책지원이 다양하게 나타나고 있다. 하지만, 윕툰산업의 경우에는 조금 다른 양상이 발생하고 있다. 한국은 무엇보다도 웹툰이라는 장르의 종주국일 뿐 아니라 거의 대부분의 웹툰 콘텐츠 제작이 국내에서 이루어지고 있다. 따라서 현재의 관점에서 
는 웹툰 장르의 해외진출이 한국 웹툰산업의 해외진출이 되는 것으로 봐도 될 정도로 웹툰산업에서 한국이 차지하는 위치가 크다.

다만, 여기에서 정책적으로 주목해야할 점 중에 하나는 웹툰은 국내에서 글로벌 플랫 폼을 선점하고 있는 거의 유일한 콘텐츠산업이라는 것이다. 전 세계에 국내의 플랫폼들 이 이미 퍼져있고 이 플랫폼들의 중심 콘텐츠는 한국에서 제작된 웹툰들이 있다. 따라서 글로벌 플랫폼에서 국내 제작 콘텐츠들을 활발하게 진출시키고자 하는 소극적인 진출이 아닌 글로벌 콘텐츠 자체와 장르 자체를 선점한 상태에서 이들의 수출을 활성화하는 적 극적인 진출이 이루어지고 있는 것이다. 따라서 이전 콘텐츠 정책에서 경험하지 못했던 플랫폼 수출 방식에 대해 정부에서는 어떠한 정책적 지원을 고민해야하고 시장이 해결 해주지 못하는 문제들을 어떻게 보완해 나가야하는지에 대한 정책요구가 높아지고 있다.

\section{라. 콘텐츠산업의 디지털 전환 기회}

한 가지 확실한 사실은 디지털화로 전환하고 있는 전 세계의 만화산업의 변화 기조와 맞물려 웹툰산업은 한 단계 도약할 수 있는 모멘텀의 기회를 맞이하고 있다는 것이다. 온라인 및 모바일 망이 전 세계적으로 갖춰지고 스마트 기기의 보급이 확대되어 콘텐츠 산업의 모든 장르들은 디지털 유통을 본격화하고 있다. 특히 코로나 19 로 인한 비대면 콘텐츠 시장의 활성화는 디지털 기반 만화산업인 웹툰 산업을 알리고 확산할 수 있는 기회로 작용하고 있다.

실제로 출판만화가 주를 이맀던 미국 만화시장이나 일본만화 시장에서도 이번 코로나 19발 팬데믹으로 인해 만화책을 사거나 볼 수 있는 장소의 방문이 어려워지면서 오프라 인 유통업체들이 위기에 처했다. 그리고 출판사 등 만화 IP를 가지고 있는 만화 제작사 들도 다급하게 온라인화를 시도하고 있다. 디지털 변환 국면에서 글로벌 이용자와 만화 제작사들을 유입시켜 웹툰의 수요와 공급을 동시에 확장할 수 있는 절호의 기회를 맞이 한 샘이다.

따라서 글로벌 디지털 만화시장을 선도하기 위해 웹툰산업 해외진출에서 활용할 강점 과 문제점을 파악하고, 각 지역별 해외 현지시장의 현황을 객관적으로 분석하여 해외진 출을 본격화할 수 있는 체계적인 진흥방안 마련이 필요한 시점이다. 
[그림 1-1] 연구 배경 및 필요성

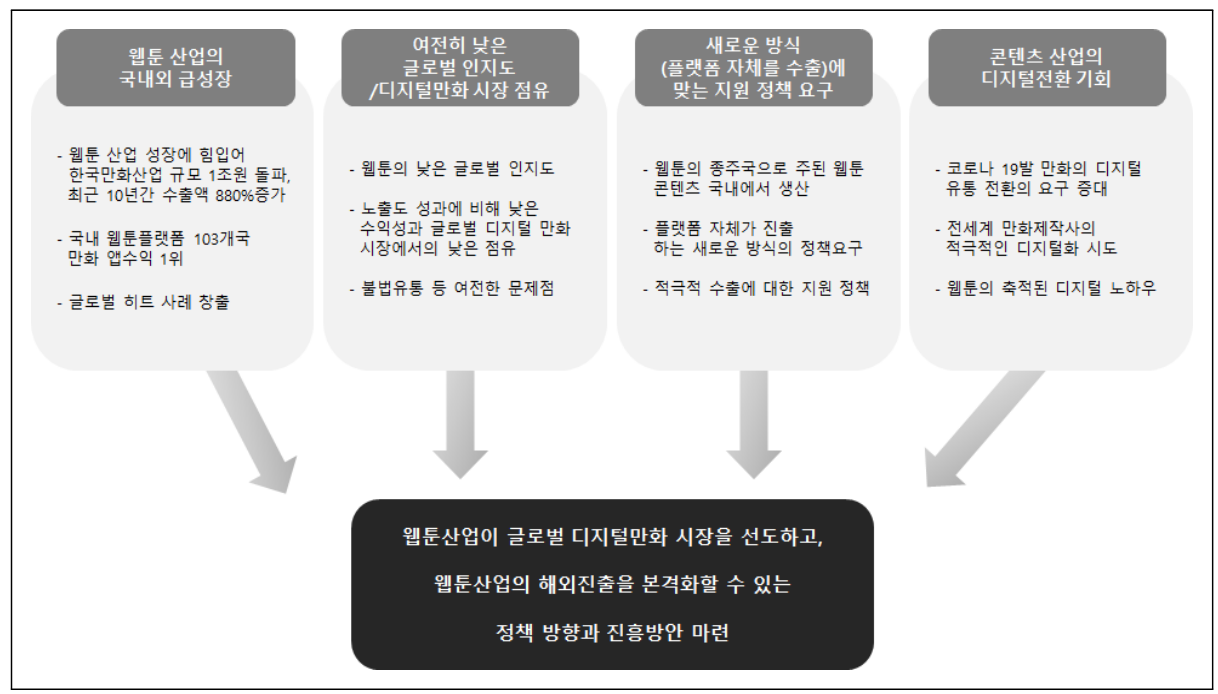

\section{2. 연구 목적}

본 연구는 해외진출이 본격화되고 있는 웹툰 산업의 현황과 차별점을 파악하는 한편 해외 디지털 만화 현황을 객관적으로 파악하여 문제점들을 도출하고 이를 극복하여 해 외진출을 활성화할 수 있는 전략방향과 방안을 도출하는데 목적이 있다. 구체적으로는 다음의 네 가지로 연구 목적을 정리할 수 있다.

첫째, 웹툰 산업의 현황과 특성을 객관적으로 진단하여 해외진출 시 극대화할 수 있는 특장점과 문제점을 도출하는 것이다. 웹툰 자체의 특성뿐 아니라 주요 이슈와 특성을 분석하여 웹툰 만이 지니는 디지털 만화로의 장점과 글로벌 경쟁력을 살펴보고자 한다.

둘째, 지역별 디지털 만화시장 현황과 웹툰 진출 현황을 살펴보고 웹툰의 해외 진출 시의 문제점과 기회점을 도출하고자 한다. 일본, 미국, 유럽, 동남아시아 등 해외 주요국 및 지역의 디지털 만화의 가능성을 분석하여 웹툰이 비집고 들어갈 기회와 가능성을 살 피고자 한다. 또, 웹툰의 진출 현황을 살펴보는 과정에서 해외진출의 한계와 보완해야할 점들을 지역별로 파악하여 지역별 진출 방향성을 체계적으로 파악하는 것이다.

셋째, 웹툰 산업이 고도화되고 있는 과도기 시점이라는 전제 이래 이미 글로벌적 성공 을 이룬 만화선도국의 고도화 사례를 분석하여 과도기적 상황에서 어떠한 노력과 성공 
요인을 지녔는지를 분석하여 웹툰산업에 적용할 요소들을 찾아내는 것이다.

넷째, 웹툰산업 해외진출과 관련한 현재의 정부 정책방향과 현행 세부 사업들을 분석 하여 웹툰산업이 처한 현 상황에 비추어보았을 때 적절히 대응을 하고 있는지를 진단하 고, 개선방향과 세부 개선점들을 도출하는 것이다.

마지막 분석한 결과를 종합하여 웹툰산업의 해외진출을 활성화 할 수 있는 실질적 전략 방향과 진흥방안을 수립하여 웹툰산업의 지속적 성장과 글로벌 확장에 기여하는 것이다. 


\section{제2절 연구범위 및 방법}

\section{1. 연구 범위}

\section{가. 시간적 범위}

본 연구의 시간적 범위는 웹툰이 발생한 2003년부터 2021년 9월(연구 시점)까지, 18 년간을 대상으로 한다.

\section{나. 공간적 범위}

본 연구의 공간적 범위는 온라인 기반(네트워크, 디바이스 등)이 갖춰져 있어 웹툰이 진출할 수 있는 전 세계 국가와 지역을 공간적 범위로 특정하였다. 특히, 한국을 비롯한 미국, 일본, 유럽, 동남아시아 등 디지털 만화시장이 발달하기 시작했고, 웹툰 산업이 현지시장에 진입하여 일정 성과를 거두고 있는 지역을 중심으로 연구를 진행하였다.

\section{다. 분석대상 범위}

본 연구의 분석 대상은 다음과 같다. 첫째, 웹툰산업의 전반적인 일반 현황과 해외진 출 현황이다. 웹툰산업의 일반현황은 웹툰 시장과 웹툰 생산의 대부분을 담당하고 있는 국내 웹툰산업을 중심으로 다루며 웹툰의 특징과 발전과정은 물론, 주요 이슈 트렌드, 산업규모와 비즈니스 모델 등을 다양한 측면에서 현황을 살핀다. 해외 현황은 주요 분석 대상을 일본, 미국, 유럽, 동남아시아로 나누어 크게 현지의 디지털 만화 현황을 파악하 고, 그 가운데 웹툰이 현지에서 얼마나 성과를 거두고 한계를 지니고 있는지 진출현황에 대해 살펴본다.

둘째, 만화 선도국인 일본과 미국을 대상으로 고도화 사례를 분석한다. 이미 만화의 
규모는 물론 해외진출까지 성공적으로 이룬 두 국가의 고도화 과정을 분석하고, 그 제작 및 유통 시스템을 구체적으로 분석하여, 고도화 과정을 거치고 있는 웹툰 산업에 적용할 요소들을 도출해 내고자 한다.

셋째로는 웹툰 해외진출 관련 정부의 정책현황에 대해 진단하고 분석한다. 특히 상위 계획인 만화발전 계획에서부터 한국콘텐츠진흥원이나 한국만화영상진흥원의 해외진출 진흥 사업까지 현재까지 추진되고 있는 정책의 방향성과 세부사업을 구체적으로 진단하 여 그 성과와 한계점을 살펴본다.

마지막 넷째는 웹툰의 해외진출 활성화를 위해 기본 정책방향과 세부 정책방안을 수 립하는 것이다. 현황파악을 통해 나타난 웹툰산업의 해외진출에서의 기회와 문제점, 특 장점 등을 종합하여 해외진출 활성화에 기여할 수 있는 정책 방향을 수립하고 이를 구체 화할 수 있는 세부 방안을 도출한다.

\section{2. 연구 방법}

\section{가. 문헌 연구}

웹툰산업 및 해외진출 현황을 파악하고 고도화 과정을 구체적으로 살펴보기 위하여 문헌연구를 진행하였다. 구체적으로 웹툰 산업 및 콘텐츠 해외진출 관련 논문, 연구보고 서, 증권 리포트, 민간기관 리포트 등 기관자료, 통계자료, 기업자료 등 다양한 정보채널 을 통해 자료를 확보하고 이를 검토하였다.

\section{나. 전문가 및 업계 인터뷰}

웹툰 업계전문가(플랫폼, 에이전시, 스튜디오 등), 웹툰 작가, 웹툰 관련 학계 전문가, 연구계 및 관계 전문가(한국콘텐츠진흥원, 한국만화영상진흥원 등 웹툰 해외진출 사업 담당자, 협회)를 대상으로 심층인터뷰를 진행하였다.

\section{다. 해외 사례 분석}

만화 선도국으로 분류할 수 있는 일본과 미국의 고도화 과정에 대해 사례분석을 진행 
하였다. 사례분석은 일본과 미국의 현지자료는 물론, 해당 지역에서 만화사업을 하거나 공부를 해 본 경험이 있는 전문가들을 대상으로 인터뷰를 진행하여 폭넓고 깊이 있는 사례분석을 진행하였다.

\section{라. 웹툰 해외진출 지원 정책 분석}

만화산업 발전계획 등 상위계획 검토 및 현행 웹툰 해외진출 관련 지원사업을 분석하 였다. 특히 지원사업 분석의 경우에는 각 기관별 업무계획 및 성과보고서를 중심으로 2 차 자료 분석뿐 아니라 해당 기관 사업 담당자와의 인터뷰를 통해 심층적인 내용들을 도출하였다.

[그림 1-2] 연구의 수행방법 및 과정

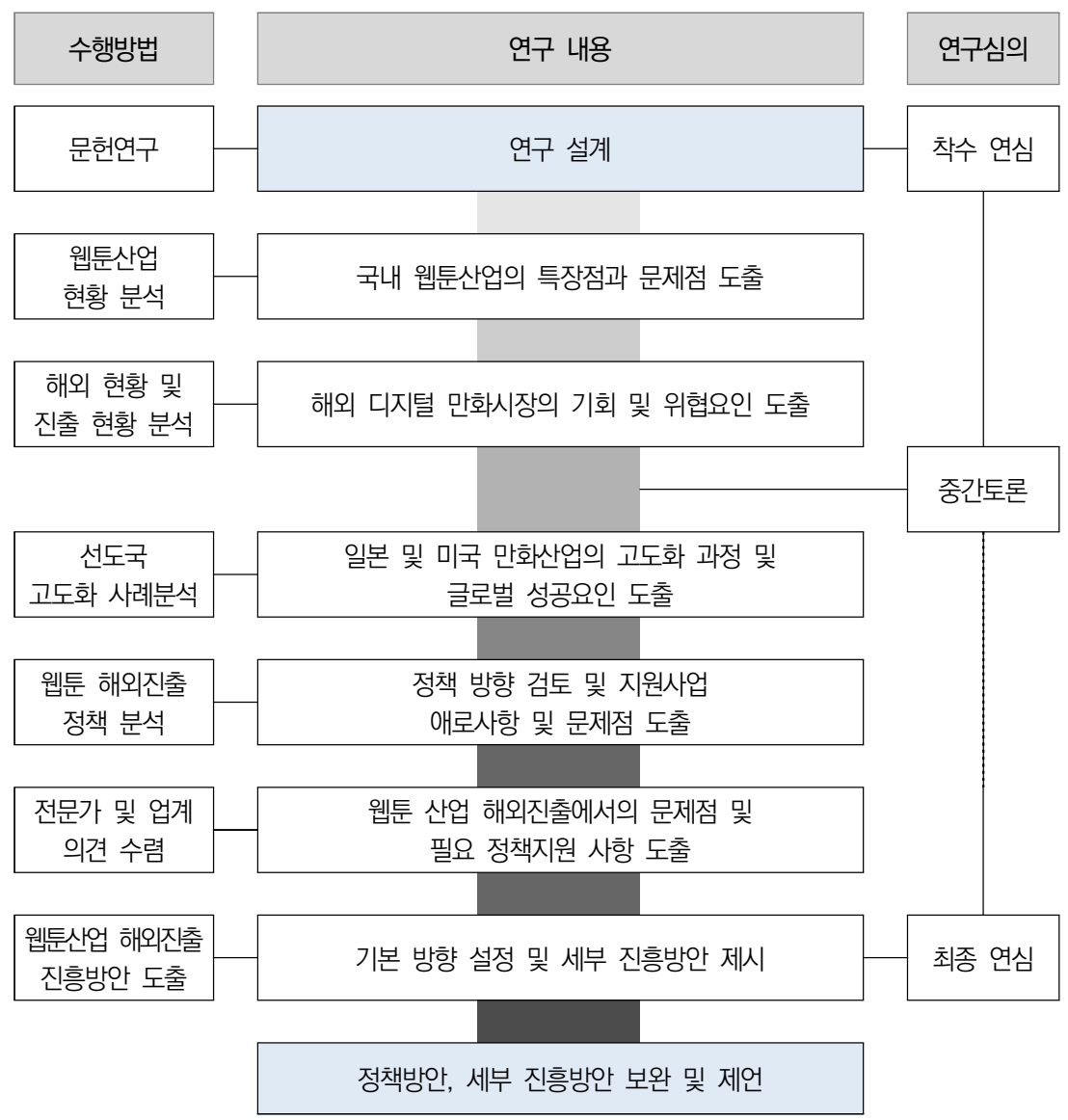


웹툰산업 해외진출 진흥 방안 연구

제2장

웹툰산업 현황 



\section{제1절 웹툰산업 개요}

\section{1. 웹툰 및 웹툰산업의 정의와 범위}

\section{가. 웹툰 및 웹툰산업의 정의}

웹툰은 한국에서 개발한 디지털 만화의 한 종류로, 인터넷으로 정보를 공유하는 가상 공간인 '웹(web)'이라는 미디어 용어와 만화를 뜻하는 '카툰(cartoon)'이라는 장르 용어 가 결합해 만들어진 합성어이다. 그 어원에서도 유추할 수 있듯 웹툰은 온라인 환경에서 의 게재 목적을 가지고 제작 및 유통하여 디지털 기기에서 소비하기에 최적화한 만화 장르를 일컫는다. 즉, 웹툰은 디지털 방식으로 제작과 편집이 이루어지고 온라인 플랫폼 과 디지털 기기를 통해 유통과 소비가 발생하는 등 콘텐츠 가치사슬(value chain) 전체 에 걸쳐서 디지털 방식으로 이루어지는 만화 형식이다. 그리고 이를 산업으로 확장하면 경제적 부가가치를 창출하는 웹툰 콘텐츠 또는 이를 제공하는 서비스의 제작 · 유통·이 용 등과 관련한 산업3)을 웹툰산업이라고 정의할 수 있다.

웹툰은 2000년대 초부터 한국에서 처음 발생한 장르이기 때문에 그 역사가 짧으며 법적인 정의가 아직은 독립적으로 갖추어지지 못했다. 〈만화진흥에 관한 법률〉에서도 웹툰 관련 별도 정의는 없으며 ‘출판만화’의 대응어로 '디지털만화’만이 정의되어 있다.

〈표 2-1〉 만화진흥에 관한 법률에 나타난 디지털만화의 정의

\section{제2조(정의)}

\section{〈만화진흥에 관한 법률〉}

4. "출판만화"란 출판물의 형태로 발간되는 만화를 말한다.

5. “디지털만화”란 만화를 디지털파일 형태로 가공 - 처리하고 이를 디스크 등의 디지털매체나 「정보통신망 이용촉 진 및 정보보호 등에 관한 법률」 제2조제1항제 1 호에 따른 정보통신망을 통하여 이용자에게 제공되는 만화를 말한다.

자료: 국가법령정보센터(law.co.

3)〈콘텐츠산업 진흥법〉 제1장 제2조 2 항에서 '콘텐츠산업' 정의를 대입하여 정의 
하지만 웹툰산업의 규모가 급속도로 커지고 만화산업에서 차지하는 영향력이 높아짐 에 따라 만화진흥에 관한 법률 내에 웹툰의 정의를 별도로 삽입(4)하거나 웹툰을 보다 구 체적으로 만화의 범위 내에 포함시키려는 법안의 발의와 논의가 활발5)하다.

한편, 웹툰의 범위를 체계적으로 확인해보기 위해 유통을 중심으로() 만화 전체에서의 웹툰 위치를 그려보면 〈그림 2-1〉과 같다. 웹툰은 출판만화에 상반되는 개념인 디지털 만화(digital comics)에 속하는 만화의 종류로 분류된다. 디지털 방식으로 제작 및 유통 되는 모든 만화인 디지털 만화는 e-코믹스 등 다양한 명칭으로 표현되기도 한다. 디지털 만화에는 출판만화를 그대로 스캔하여 디지털에 옮긴 '스캔 만화', 4 컷 만화나 만평 등 짧은 형식에 기반을 둔 미국의 '웹코믹스(web comis)', 그리고 '웹툰' 등이 포함된다. 웹툰이 해외에서는 아직 대중적으로 활용되고 있는 용어가 아니다보니 웹툰 관련 업체 들이 해외현지에 진출하면서 웹툰을 홍보하거나 소개할 때 세로 스크롤 형태와 컬러 등 의 특징을 지니는 디지털 만화로 설명하고 있다.

[그림 2-1] 만화의 하위 범위와 웹툰

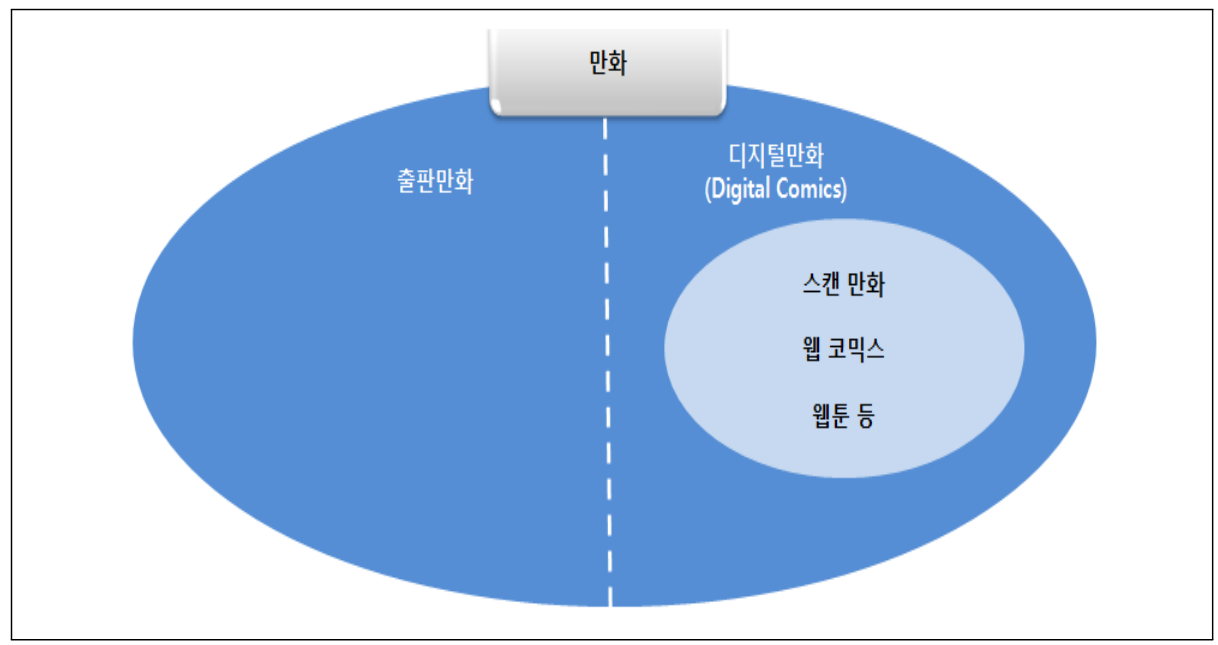

4) 2020 년 전용기 의원이 발의한 만화진흥법 개정안에는 웹툰의 정의를 신설하고, '만화'라고 단독 표기 된 것에 '만화웹툰'으로 병기

5) 2021 년 김승수 의원이 발의한 만화진흥법 개정안에는 현행 '만화'의 정의 중 '디지털매체에 담긴 것'을 ‘디지털로 제작된 것'으로 수정하여, 웹툰을 만화의 범위에 포함하려고 시도

6) 제작 관점에서 디지털 방식으로 제작이 이루어지는 것도 디지털 만화로 정의하기도 하지만, 본 연구에서는 유통 관점에 집중하여 웹툰의 범위를 살펴봄 


\section{나. 웹툰산업의 주체와 역할}

웹툰산업에는 다양한 주체가 각자 역할을 담당하고 있다. 이들을 역할에 따라 구분하 면 웹툰을 제작하는 작가와 웹툰 스튜디오, 웹툰을 유통하는 웹툰 플랫폼, 그리고 기획, 제작, 유통까지 관여하는 웹툰 에이전시 등으로 나눌 수 있다.

〈표 2-2〉 웹툰산업 주체

\begin{tabular}{c|c|c}
\hline 구성원 & 내용 & 비고 \\
\hline 웹툰 작가 & - 웹툰을 기획하고 제작하여 연재하는 창작자 & $\begin{array}{l}- \text { 웹툰 작가 수는 2019년 } \\
\text { 기준으로 3,438명 }\end{array}$ \\
\hline \multirow{2}{*}{ 웹툰 스튜디오 } & $\begin{array}{c}\text { ㅇㅞㅞ툰을 기획하여 분업화된 형태로 전문적으로 제작하는 } \\
\text { 업체 }\end{array}$ & - 대형화되고 있는 추세 \\
\hline \multirow{2}{*}{ 웹툰 플랫폼 } & $\begin{array}{c}\text { 웹툰 콘텐츠를 온라인 상으로 유통하는 사업자로 온라인 } \\
\text { 포털사이트 운영을 주된 업으로 하는 포털사와 웹툰 } \\
\text { 유통을 주업으로 하는 웹툰 전문업체로 구분 }\end{array}$ & $\begin{array}{c}\text { 2019년 기준으로 웹툰 } \\
\text { 플랫폼 업체는 31개 }\end{array}$ \\
\hline \multirow{2}{*}{ 웹툰 에이전시 } & $\begin{array}{c}\text { 웹툰의 기획, 제작, 유통 각 과정을 지원하여 웹툰 } \\
\text { 켄텐츠의 품질을 높이고 비즈니스 경로를 확대하여 이익을 }\end{array}$ & $\begin{array}{c}\text { - 2020년 기준 40개 } \\
\text { 이상의 전문에이전시가 } \\
\text { 흑대화시키는 역할을 수행하는 업체 }\end{array}$ \\
\hline
\end{tabular}

먼저, 웹툰 작가는 웹툰을 기획하고 제작하여 연재하는 주체, 즉 창작자를 말한다. 주 된 역할은 크게 작화, 스토리 구상 및 연출 이렇게 두 가지로 나뉘는데, 경우에 따라 이 두 가지 모두를 한 사람이 담당하기도 한다. 수익배분은 작품의 컨셉, 팀의 구성 방식에 따라 차이를 보이지만, 업계 통상 그림 작가에게 더 많은 수익을 배분하는 편이다. 한국 콘텐츠진흥원에 따르면 웹툰 작가 수는 2019년 기준으로 3,438명7)에 이르고 있으며 웹툰산업이 활성화되고 스타 작가가 생기는 등 웹툰작가가 사회적 선망의 대상이 되면 서 그 수가 매년 급격히 증가하고 있다.

다음으로 웹툰 스튜디오는 웹툰을 기획하여 주로 대규모의 분업화된 형태로 전문적으 로 제작하는 업체를 말한다. 스튜디오 체계는 마블(Marvel)이나 디씨코믹스(DC Comics) 등과 같이 만화 선도국에서 만화의 산업화가 본격적으로 진행되는 과정에서 발생된 제작 체계이기도 하다. 우리나라에서는 웹툰 플랫폼에서 자체 제작스튜디오를 설 립하여 진행하는 경우가 있는가 하면, 플랫폼과는 별개로 독립적인 제작 스튜디오를 설 립한 경우도 있다. 한국 웹툰의 경우 그 성장과정에 있어 대형 플랫폼의 역할이 컸기

7) 2020 웹툰 작가 실태조사(2020, 한국콘텐츠진흥원) 
때문에 대형 플랫폼 산하의 웹툰 제작 스튜디오의 성과가 좋은 편이다.

웹툰 플랫폼은 웹툰 콘텐츠를 온라인 상으로 유통하는 사업자로 온라인 포털사이트 운영을 주된 업으로 하는 포털사와 웹툰 유통을 주업으로 하는 웹툰 전문업체로 구분 될 수 있다. 2010년대 까지는 '네이버웹툰', '다음웹툰' '야후웹툰', '네이트 웹툰판' 등 포털사를 중심으로 웹툰이 발전해 오다가, 2013년 레진코믹스가 성공적인 유료화 서비 스를 시작한 이래로 다수의 후발업체가 등장하여 웹툰의 유통 생태계가 두텁게 구성되 기 시작하였다. 한국콘텐츠진흥원의 조사에 따르면 2019년 기준으로 국내의 웹툰 플랫 폼 업체는 31 개 정도로 집계되고 있는데 상위 플랫폼 10 개가 전체 트레픽의 97\%를 넘 게 차지8)하여 극단적인 양극화가 발생하고 있다.

〈표 2-3〉 주요 웹툰 플랫폼

(단위: 원)

\begin{tabular}{c|r|r|r}
\hline 플랫폼 명 & 페이지뷰(PV) & 페이지뷰(PV) 점유율 & 웹툰부문 매출액 \\
\hline 네이버웹툰 & $21,451,015,015$ & $65.1 \%$ & $64,409,403,960$ \\
\hline \multirow{2}{*}{$\begin{array}{c}\text { 카카오페이지 } \\
\text { /다음웹툰 }\end{array}$} & $5,131,972,979$ & $15.6 \%$ & \multirow{2}{*}{$102,824,866,054$} \\
\cline { 1 - 4 } 레진 & $1,293,203,255$ & $3.9 \%$ & \\
\hline 탑툰 & $1,530,172,414$ & $4.6 \%$ & $34,542,213,504$ \\
\hline 투믹스 & $1,090,726,334$ & $3.3 \%$ & $53,731,198,533$ \\
\hline 봄툰 & $605,730,171$ & $1.8 \%$ & $15,347,318,210$ \\
\hline 무툰 & $451,423,039$ & $1.4 \%$ & $25,189,265,940$ \\
\hline 배틀코믹스 & $216,218,118$ & $0.7 \%$ & $10,500,000,000$ \\
\hline 미스터블루 & $140,168,224$ & $0.4 \%$ & $1,202,710,000$ \\
\hline 저스툰 & $84,954,536$ & $0.3 \%$ & $31,288,922,410$ \\
\hline 태피툰 & $82,565,482$ & $0.3 \%$ & $11,743,635,000$ \\
\hline 미소설 & $71,255,830$ & $0.2 \%$ & $16,000,000,000$ \\
\hline 피너툰 & $60,016,331$ & $0.2 \%$ & $951,330,552$ \\
\hline 폭스툰 & $47,110,382$ & $0.1 \%$ & $5,808,884,000$ \\
\hline 리디북스 & $32,976,750$ & $0.1 \%$ & $231,000,000$ \\
\hline 합계 & - & - & $5,735,148,729$ \\
\hline
\end{tabular}

자료: 웹툰 사업체 실태조사 보고서(2020, 한국콘텐츠진흥원)

8) 만화산업분류체계 개편 및 분석연구(2020, 한국콘텐츠진흥원) 
웹툰 에이전시는 웹툰의 기획, 제작, 유통 각 과정을 지원하여 웹툰 콘텐츠의 품질을 높이고 비즈니스 경로를 확대하여 이익을 극대화시키는 역할을 수행하는 업체를 말한다. 초기의 에이전시는 주로 웹툰 플랫폼에 작품을 공급하는 유통의 역할만을 수행하며 단 순히 수수료의 일부를 작가에게서 배분받는 형태로 비즈니스를 전개하였다. 하지만 최근 에는 에이전시의 역할이 더 정교화되어 웹툰을 기획하고, 작가를 섭외할 뿐 아니라 제작 및 편집에까지 참여하고 작품 홍보까지 관여하는 등 모든 과정에 참여하고 있다. 에이전 시 중에는 스튜디오를 설립하여 웹툰의 저작권을 $100 \%$ 소유하는 경우도 늘어나고 있다. 한국콘텐츠진흥원에 따르면 2017년 90여 개에 불과하였던 에이전시의 수는 2018년 150 여 개, 2019년 200여 개로 폭발적으로 증가하고 있다. 여기에, 웹소설 업체들도 웹 툰 에이전시 부문으로 적극적으로 뛰어들면서 에이전시 시장의 규모가 급속히 확장되는 중이다.

〈표 2-4〉 국내 주요 웹툰 에이전시 현황

\begin{tabular}{|c|c|}
\hline 에이전시 명 & 대표작 \\
\hline 재담미디어 & 〈킹스메이커〉, 〈약한영웅〉 등 \\
\hline (주)와이랩YLAB & 〈스터디그룹〉, 〈하우스키퍼〉 등 \\
\hline 드림커뮤니케이션 & 〈황제의 딸로 태어났습니다〉 등 \\
\hline 디앤씨미디어 & 〈악역이 베푸는 미덕〉, 〈나 혼자만 레벨업〉 등 \\
\hline 투니드엔터테인먼트 & $\langle$ 〈이게 무슨 황비〉, 〈어쩔꼰대〉 등 \\
\hline JQ스튜디오 & 〈여름은 뜨겁다〉, 〈바다가 소년에게〉 등 \\
\hline 유주얼미디어 & 〈블러드 링크〉, 〈황비님의 비밀수업〉 등 \\
\hline 크릭앤엔터테인먼트 & 〈여명의 눈동자〉, 〈군바리와 고무신〉, 〈스트레서〉 등 \\
\hline 스토리숲 & 〈황비님? 황비님!〉, 〈프렌시아의 꽃〉 등 \\
\hline 키다리이앤티(키다리스튜디오) & $\langle$ 수상한 레시피〉, 〈W.O.W〉 등 \\
\hline 지티이엔티 & 〈잭슨의 관〉, 〈풍월주〉 등 \\
\hline (주)다온크리에이티브 & 〈황제의 외동딸〉, 〈이세계의 황비〉 등 \\
\hline 대원씨아이(주) & 〈흰사슴 잉그리드〉, 〈다정하게 쓰담쓰담〉 등 \\
\hline 팬덤콘텐츠팩토리 & 〈황자님께 입덕합니다〉 등 \\
\hline 서울미디어코믹스(서울문화사) & 〈내일은 이렇게 입어〉, 〈100억의 주인〉 등 \\
\hline
\end{tabular}

자료: 만화산업백서(2020, 한국콘텐츠진흥원) 


\section{2. 웹툰 및 웹툰산업의 특징}

\section{가. 세로 스크롤 방식과 컬러 구성}

웹툰의 특징을 꼬집어 말하기는 어렵지만, 다른 디지털 만화와 가장 큰 차별점은 세로 형태로 이루어져 디지털기기에 최적화된 세로 스크롤 연출 방식을 통해 가독성을 극대 화 한다는 점이다. 기존의 스캔 방식의 디지털 만화는 일반 출판형태를 모바일 폰에서 보려면 확대와 축소를 반복하며 보아야 한다는 불편함이 있다. 그에 비하여 웹툰의 세로 스크롤 형식은 에피소드 당 약 50에서 100여 컷 이상으로 구성된 만화를 편하게 세로로 넘기는 형태로 볼 수 있다.

세로 스크롤 방식은 기존의 방식 대비 다양한 극적 효과를 표현하기에 유리한 측면이 있다. 만화에서 이미지와 이미지 사이의 거리, 크기, 위치 등을 적극적으로 조절하여 크 리티컬 신을 만들어 내는 것이 매우 중요한 부분인데 웹툰에서는 이미지 부분에서 독자 의 스크롤 속도를 조정하는 '크리티컬 신(critical scene)'을 활용한 다양한 연출 방식이 시도되기도 한다. 이를 통하여 독자들이 캐릭터와 동일시 및 감정이입이 되도록 유도하 기도 하고 서스펜스를 창출하고 액션 표현을 극대화 하는 등의 표현 차이를 만든다.

[그림 2-2] 세로스크롤과 컬러를 통한 극적 효과9)

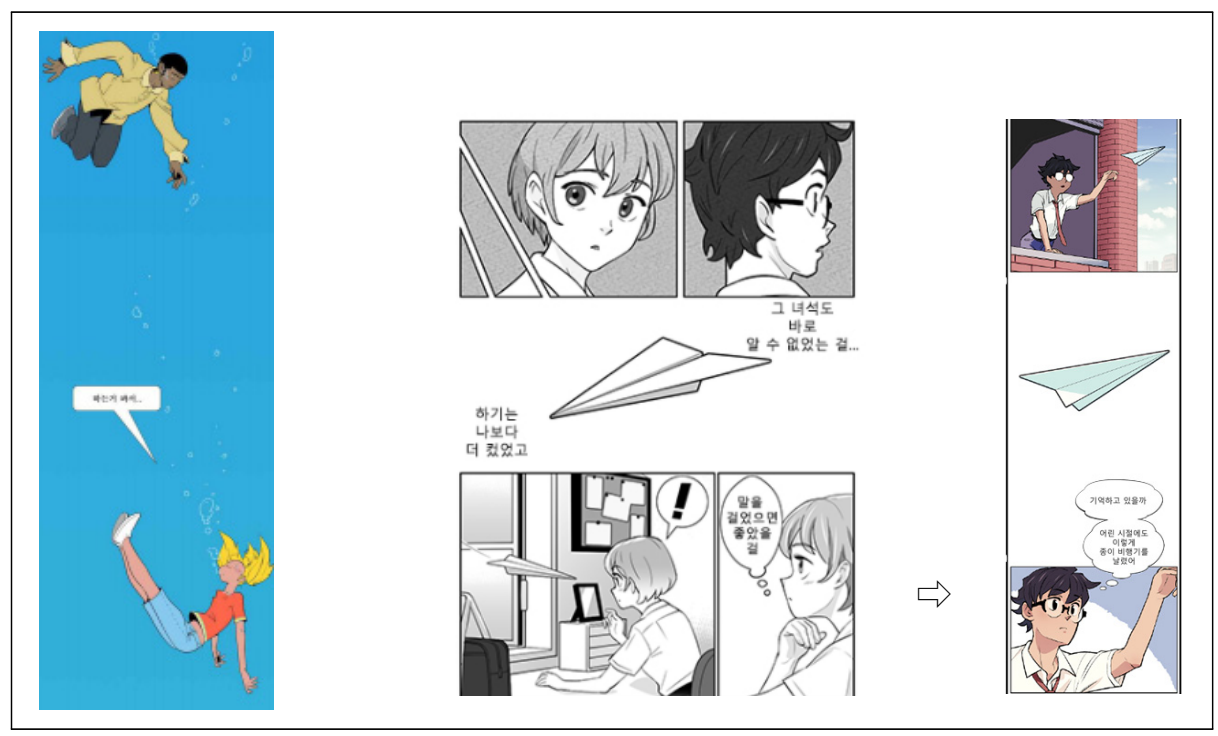

9) 강도하의 〈로맨스 킬러〉, 클립스튜디오: https://uww.clipstudio.net/drawing/archives/157017 
거의 대부분 컷이 컬러로 구성된다는 점 역시 웹툰의 특성이다. 일반 출판 만화는 인 쇄비의 한계로 톤이나 먹칠로 연출을 하지만 웹툰은 컬러로 구성해도 유통상에서 비용 이 높아지지 않아 다양한 색을 사용할 수 있다. 때문에 선명한 색을 활용할 수 있는 디지 털 기기의 디스플레이 환경에 맞도록 다양하고 생생한 색을 사용하는 것이 일반적이다.

\section{나. 빠른 연재 주기(신속한 제작 및 유통 기간)}

웹툰은 일반적으로 한 에피소드를 주 1편씩 보통 50 100여 컷 규모로 제작하여 플랫 폼에 바로 연재하는데, 이는 기존의 출판 만화보다 빠른 속도이다. 처음에는 이러한 빠 른 연재 주기를 표준화된 특성이라고 보기는 어려웠으나, 웹툰 플랫폼에 의한 빠른 유통 을 살릴 수 있는 빠른 생산이 이루어지면서 빠른 연재 주기가 이제는 웹툰의 강점으로 인식되고 있다. 속도가 빠르다는 점은 여러 가지 이점을 가져다주는데, 빠른 전개와 호 흡으로 인해 독자 이탈율을 낮출 수 있고, 꾸준한 연재로 인해 다수의 콘텐츠를 확보할 수 있게 되었다.

바른 연재 주기는 웹툰 제작 작업의 분업화 및 스튜디오화를 촉진시켰다. 기존의 만화 는 가내 수공업 형태에서도 가능하나, 웹툰의 빠른 연재 주기로 인해 짧은 기간 내에 고품질의 웹툰을 생산해 내기 위해 분업이 일반화되었다. 초기의 웹툰은 기획 및 작화에 비교적 시간이 덜 들어가는 일상, 개그 중심의 다소 가벼운 소재들이 주를 이루며 대표 적인 스넥컬쳐로 인식되었다. 하지만 시간이 흐르면서 작업 시간이 촉박한 웹툰 작가들 은 어시스턴트를 활용하여 채색 등 디자인 작업을 보완하게 되었고, 스토리와 그림의 업무를 분담하여 팀 단위로 작업을 진행하게 되었다. 시간이 지날수록 스튜디오 시스템 의 제작과 전문 에이전시 등 체계적이고 분업화된 시스템이 자리 잡게 되면서 1 주일 주 기에도 불구하고 내용이나 그림의 질(quality)이 우수한 웹툰이 연재되게 되었다.

\section{다. 댓글을 통한 소통}

웹툰은 댓글을 통한 패드백이 활성화되어 있으며 이를 통해 작가와 독자들이 소통하 고 독자들끼리도 소통하는 창구가 되고 있다. 댓글은 작가와 독자가 작품에 대해 의견을 주고받는 기능을 하지만 작품 내용과는 무관하게 작가와 독자의 친밀감을 높이는 소통 
의 창구 기능을 하고 있다. 최근에는 웹툰을 볼 때 작품만 보는 것이 아니라 그에 달린 댓글까지 읽어야 웹툰 한편을 다 보았다고 생각하는 공감의 문화가 형성될 정도로 댓글 의 기능이 커지고 있다. 작가 역시 댓글을 통하여 다양한 스토리를 전개할 수 있는 소재 를 얻기도 하고, 일종의 팬덤의 커뮤니티 역할을 하기 때문에 댓글이 웹툰 소비층을 두 텁고 넓게 형성하는데 기여하고 있다. 인기 있는 작품의 경우 독자들의 커뮤니케이션 활동이 더욱 활발하게 이루어지고 있다. 카페, 블로그, SNS 등을 통해 작가가 독자가 소통하기도 하고 창작자가 직접 유튜브 채널을 만들어 웹툰을 주제로 콘텐츠를 만들거 나 해석, 내용 예측 등을 하는 경우도 있다. 일례로 '신의탑' 2 부 20 화는 댓글이 101 만 개가 달리기도 하였다.

독자들과의 소통과 유대관계 구축은 작가 데뷔에도 영향을 주고 있다. 포털사이트들 은 독자와 작가의 유대관계를 더욱 강화하기 위해 '나도만화가, 도전만화(베스트도전)' 등의 리그 코너를 개설하고 정기적으로 공모전을 개최해 독자들의 참여(평가 및 도전)를 유도하고 있다. 독자들은 자신이 지지하던 만화가 ‘베스트'에 선정되어 정식으로 연재되 는 모습을 지켜보며 스스로 작가를 발굴하고 육성했다는 인식을 갖게 되고 이는 작품과 작가 대한 유대 강화로 연결된다.

\section{라. 신기술 융합이 활발}

웹툰은 기술과 만화 간의 결합을 통한 시너지 효과를 만들어 낸 대표적인 성공 시례이 다. 웹툰에는 기존의 출판 만화 대비 차별화된 새로운 가치와 기능을 제공하기 위해 인 터넷 및 모바일 기술이 적용했으며, 현재도 다양한 신기술 적용을 시도하는 중이다. 웹 툰은 모바일로 보는 경우가 많기 때문에 모바일 기기를 통한 신기술 적용이 용이하다. 또한 작가들과 독자들도 상대적으로 신기술 적용에 개방적 성향을 지녀 다양한 시도들 이 이루어진다.

웹툰에 적용할 수 있는 기술은 다양할 수 있지만 음향, 플래시 적용은 가장 손쉽게 적 용할 수 있는 기술이다. 네이버 웹툰이나 다음 웹툰에서는 음향이나 배경음악이 담긴 웹 툰을 지속적으로 시도하고 있으며 성우 더빙을 비롯해서 인물의 대사를 모바일 메신저처 럼 나열하는 서비스 등을 선보인 바 있다. 증강현실 기술 역시 적용이 용이하다. 2016년 연재된 단편시리즈 〈폰령〉에서는 등장인물이 한 명씩 목격하는 귀신 캐릭터가 AR을 통 
해 독자 바로 앞에 나타나는 효과를 연출하였다. AI 기술과의 융합도 시도된 바 있다. 2017년 연재된 하일권 작가의 〈마주쳤다〉에서는 독자가 스마트폰 카메라로 자신의 얼굴 을 찍으면 AI기반으로 독자를 닮은 주인공으로 등장시키는 방법이 활용된 바 있다.

[그림 2-3] AR 기술을 적용한 〈폰령〉10) (위), Al 기술을 적용한 〈마주쳤다〉 (아래) ${ }^{11)}$

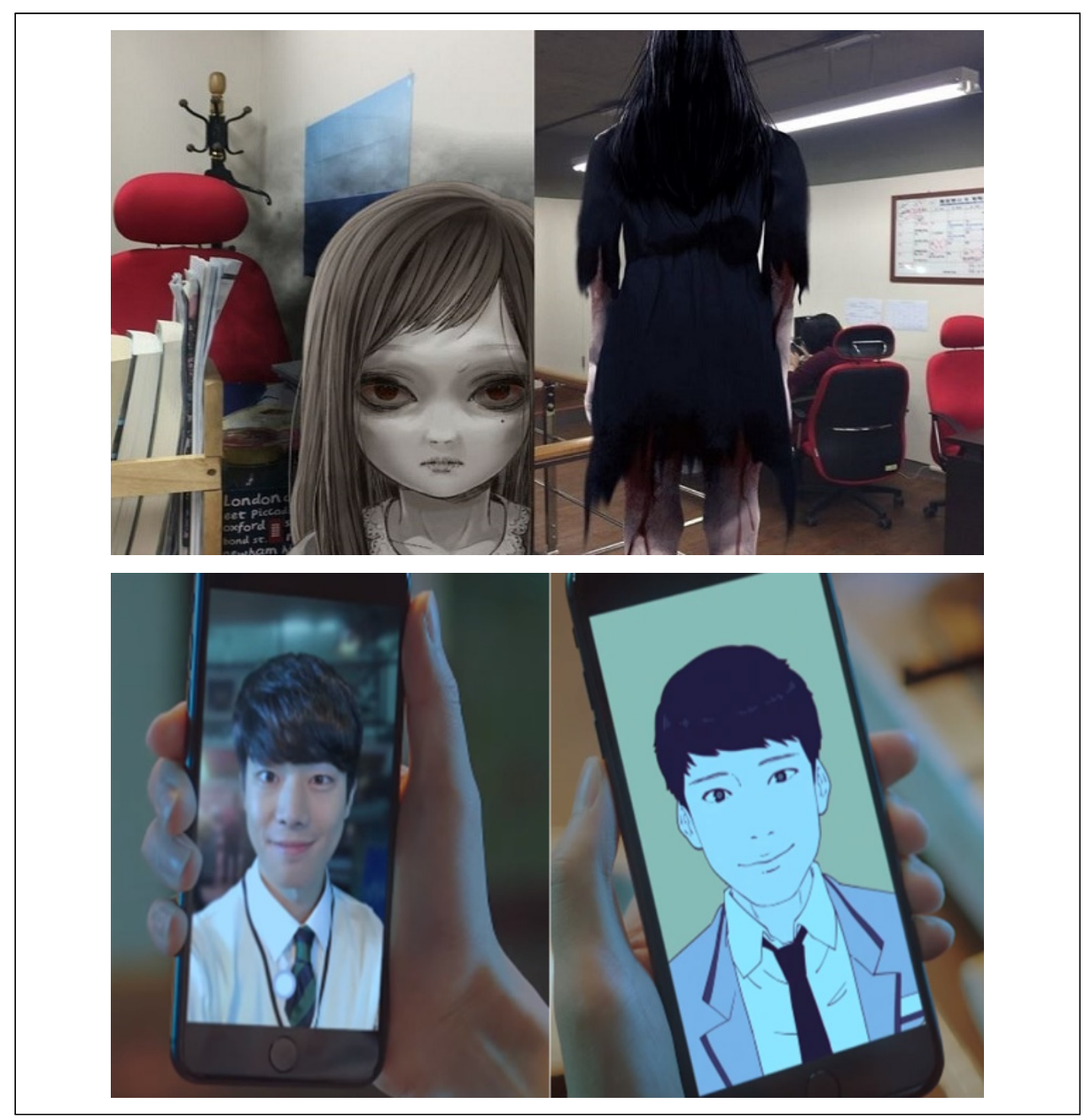

10) 시빅뉴스, 2016.10.26, "귀신이 내 방에 찾아왔다"...증강현실 기술 접목한 웹툰 출시 11) 동아일보, 2018.01.04, 윕툰에 내가 나왔으면 정말 좋겠네.*. 


\section{3. 웹툰산업의 발전과정}

\section{가. 국내 웹툰산업의 발전 과정(수명 주기)}

1) 도입기(2000년대): 포털을 중심으로 웹툰 시작

국내 웹툰산업의 발전과정은 다음과 같다. 먼저 주요 포털사이트들이 경쟁적으로 웹 코너(다음의 '만화속세상(2003년)', 네이버의 '네이버 웹툰(2004년)')를 만들어 정식으 로 작품의 연재를 시작하면서 오프라인 작가들이 출판만화를 떠나 웹툰 시장으로 유입 되기 시작하였다. 이 시기 포털사이트 야후, 파란, 엠파스, 네이트도 만화에 투자하면서 포털 중심의 웹툰시장이 형성되었다. 기존의 유명만화가의 문하생으로 시작하여 실력을 쌓고 데뷔하는 경로와 다른 공모전(베스트 도전) 등 웹툰을 통해 데뷔하는 신진 작가들 이 등장한 것도 이 시기이다. 이렇게 웹툰이 시작될 수 있었던 배경에는 초고속 인터넷 시대의 도래로 전송속도와 용량에 대한 부담이 줄었던 것이 영향이 컸다. 독자로부터 실시간 피드백을 받는 '세로스크롤 형식의 컬러, 장편이야기 웹툰' 의 연재가 시작되었 고 아이폰 출시와 함께 스마트폰을 비롯한 스마트기기들이 대중화됨과 동시에 모바일 기반의 웹툰 서비스가 시작된 것도 이 시기이다. 이후 작품성 있는 장편의 웹툰이 다수 등장하고〈위대한 캣츠비〉, 〈아파트〉, 〈바보〉, 〈이웃사람〉, 〈이끼〉, 〈은밀하게 위대하 게〉 등 웹툰을 원작으로 흥행에 성공한 영화, 드라마, 공연 등이 많아지면서 웹툰의 OSMU가 각광받기 시작하였다.

2) 성장기(2010년대): 웹툰 전문플랫폼의 등장과 유료화 정착

우후죽순 생겨났던 포털사이트 기반 웹툰은 네이버와 다음으로 포털 시장이 양분화 되면서 웹툰도 양대 포털에만 남게 된다. 이 시기에는 기존의 트래픽 기반의 무료 웹툰 에서 유료서비스 등 고정적으로 수익성을 담보할 수 있는 비즈니스 모델 개발이 시도되 는 등 변화하는 양상을 띤다. 대표적으로 2012년 다음 웹툰의 강풀 작가의 완결작부터 시범적으로 부분유료화를 시도하였고, 2012년에 등장한 웹툰 전문 플랫폼인 레진코믹 스는 성인 콘텐츠를 중심으로 한 유료화 모델을 2013년에 시도하여 성공적으로 시장에 안착하였다.

레진코믹스의 성공은 비즈니스 모델의 다양화를 촉발하였다. 이후 다양한 웹툰 전문 
플랫폼이 등장하여 유료 웹툰 시스템을 기반으로 정착(봄툰, 투믹스, 미스터블루 등)하게 되었다. 웹툰 전문 플랫폼의 등장은 웹툰 서비스의 고도화와 다양화를 이끌어내었는데, 카카오 페이지의 전신인 포도 트리는 2013년 웹툰 및 웹소설 전문 플랫폼으로 시작하여 2014년에 처음으로 '기다리면 무료' 유료화 모델을 제시하였다. 포도트리는 2015년 카 카오의 자회사로 편입되었으며 2018년에 카카오페이지로 정식명이 바뀌며 웹툰 전문 플랫폼에서 포털 계열로 편입되었다. 또한 2016년 다음 웹툰에서 연재될 회차를 유료로 선 감상할 수 있는 '미리보기' 유료서비스를 도입함으로써 3대 포털 웹툰 모두 미리보기 유료화가 적용되기도 하였다.

\section{나. 웹툰의 해외진출 발전 과정(수명 주기)}

1) 도입기(2010년대): 해외진출 시작

해외에서의 웹툰의 도입은 국내보다 10년 정도 늦었다. 2010년 이후 포털사에서 해 외의 법인 설립 등을 통해 해외진출을 시도하기 시작하였고 이때 등장한 웹툰 전문 플랫 폼에서도 일본, 미국, 중국, 유럽 등 만화 시장이 큰 국가들을 대상으로 해외진출을 시도 하기 시작하였다. 2010년 말 마일랜드는 중국 텐센트와 독점계약을 체결하였고 텐센트 의 사이트인 '동만'에 한국 웹툰 작품을 서비스하였는데 이것이 한국 웹툰 해외진출의 시초가 되었다. 2012년 타파스 미디어에서 운영하는 웹툰 형식의 플랫폼인 타파스틱이 북미에 최초로 진출하면서 웹툰 플랫폼의 해외시장을 개척하였고 2014년, $\mathrm{NHN}$ 엔터테 인먼트의 일본 자회사인 NHN PlayArt를 통해 일본 내 웹툰서비스로 코미코를 오픈하 여 성공함으로써 일본시장의 웹툰 기틀을 마련하였다. 다음 웹툰은 타파스미디어와의 제 휴로 이를 플랫폼으로 활용하여 소유하고 있던 작품들을 번역하여 해외진출을 시작하였 고, 네이버는 자사의 채팅 앱인 '라인(LINE)'을 자사의 유통망으로 활용한 '라인망가'로 일본에 진출을 시작하였다. 또한 웹툰 전문 플랫폼 레진코믹스는 2014년 중국의 U17과 큐큐닷컴 등에 연재 작품을 서비스 하며 해외진출을 시작하여 2015년 4월에 일본에, 2016년 1월에 미국에 진출을 하였다. 프랑스에는 유럽 최초 디지털만화 플렛폼인 '델리 툰'에 2016년 탑툰이 자사의 인기 웹툰 20여개를 서비스하며 진출을 시작하였다. 또한 2016년에는 일본 현지법인 카카오재팬을 통해 만든 일본의 웹툰 플랫폼 '픽코마'를 '기 다리면 무료'라는 수익모델과 함께 급성장하게 되었다. 태피툰(Tappytoon)은 한국 웹 
툰을 영어, 프랑스어, 독일어 등으로 번역하여 서비스하는 글로벌 웹툰 플랫폼으로 2016년 8월부터 서비스를 시작해 2020년 6월 기준 190여개 국가에 300만 명 이상의 독자를 확보12)하였다. 그 외에 탑툰은 대만, 일본, 중국에 진출하여 유의미한 실적을 거 두는 등 대규모의 포털업체에서부터 중소전문 웹툰업체에 이르기까지 동시다발적으로 해외진출이 적극적으로 이루어졌다.

\section{2) 여전히 도입기 혹은 성장기 초(2020년대): 앱시장 주도 및 수익성과 본격화}

2020년대 이후로는 본격적으로 웹툰의 해외진출이 활성화되어 가시적인 성과가 나타 나고 있으며 향후 매출액을 비롯해서 웹툰의 인지도가 확대되는 시기가 될 것으로 예상 된다. 네이버 웹툰은 2020년 구글 플레이 만화앱 분야 수익에서 103 개국 1 위를 기록하 였고, 월간 방문자 수(MAU)는 6,000만 명 이상으로, 월간 페이지 뷰는 105억 건 규모 로 성장-13)하였다. 카카오의 픽코마는 2020년 한 해 동안 4,100 억 원의 거래액을 기록 하였는데, 이는 전 세계 비게임 부문 앱 전체에서 3위에 해당하는 매출액14)이다. 타파스 는 월간이용자(MAU) 300만 명 이상, 8만 여종의 작품 및 80개의 오리지널 IP를 보유하 고 있으며, 2020 년 10 월 기준, 1 년 동안 5 배의 월 매출 상승을 기록15)하였다. 한편 리 디의 글로벌 웹툰 구독 서비스 만타(Manta)는 2020년 11월에 출시함과 동시에 구독모 델의 편익을 토대로 급성장하여 미국 구글 플레이스토어 만화 앱 부분 1 위를 차지16)하 였다. 태피툰도 독일, 호주, 마카오 구글 플레이에서 웹툰 매출 1 위를 차지하고 회원수 350 만 명, 월간활성이용자수(MAU)는 150 만 명을 기록하는 등 영어, 독어, 불어 등 프 리미엄 번역을 통해 경쟁력을 발휘하는 중이다. $\mathrm{NHN}$ 코미코는 영어권 국가(미국, 영국, 캐나다, 호주, 뉴질랜드)를 대상으로 포켓코믹스를 런칭하여 전세계 3,500만 누적 다운 로드를 기록 중17)이다. 2020년대 들어서 두드러진 점은 해외에서 본격적으로 수익성과 가 발생하기 시작했다는 것이다. 아직 다수의 지역에서는 무료로 제공되는 서비스가 많 아 노출대비 수익성이 높지는 않지만, 일본에서는 본격적으로 높은 수익이 창출되었다.

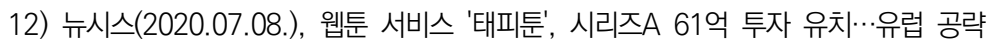

13) 뉴시스(2020.08.29.), 新한류 '웹툰' 작년 1조원 수출*-네이버·카카오 주도

14) 뉴데일리(2021.05.04.), 카카오 1분기 실적 주목... 네이버 아성 뛰어넘나

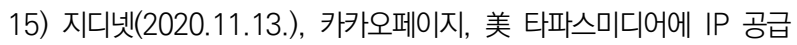

16) 앱애니 홈페이지(www.appannie.com)

17) 한국경제(2020.10.05.), 네이버와 글로벌 웹툰 1위 다투는 '태피툰' 
〈표 2-5〉 웹툰 플랫폼의 최근 해외진출 성과

\begin{tabular}{|c|c|c|}
\hline 플랫폼 & & 성과 \\
\hline \multirow{2}{*}{$\begin{array}{l}\text { 네이버 계열 } \\
\text { NAVER }\end{array}$} & TOON & $\begin{array}{l}\text { - 2019년 구글 플레이 만화 카테고리 } 103 \text { 개 국가 만화앱 분야 수익 } \\
\text { 전 세계 1위 기록 } \\
\text { - 월간 방문자 수(MAU)는 } 6,000 \text { 만 명 이상으로, 월간 페이지 뷰는 } \\
\text { 105억 건 규모 }\end{array}$ \\
\hline & $\begin{array}{l}\text { LINE } \\
\text { マンガ }\end{array}$ & $\begin{array}{l}\text { - 일본 디지털 만화 시장에서 점유율 } 38 \% \text { 로 } 1 \text { 위 차지 } \\
\text { - 슈에샤, 고단샤, 쇼가구칸 등 일본의 유명 출판사들과 파트너십을 맺 } \\
\text { 고 메신저 라인의 브랜드 파워를 토대로 성공 }\end{array}$ \\
\hline \multirow{3}{*}{$\begin{array}{l}\text { 카카오 계열 } \\
k a k a O\end{array}$} & & $\begin{array}{l}\text { - 월간이용자(MAU) 300만명 이상, 8만 여종의 작품 및 80개의 오리 } \\
\text { 지널 IP를 보유 } \\
\text { - 월 매출은 카카오페이지 IP공급 후 2020년 10월 기준 전년 동기대비 } \\
\text { 5배 상승했으며 IP공급 시점 전후로 약 } 30 \% \text { 매출 상승률 }\end{array}$ \\
\hline & 픽코마 & $\begin{array}{l}\text { - 2019년 4월 기준 이용자 수 380만 명을 기록 } \\
\text { - 픽코마 앱의 누적 다운로드 건수는 2,000만 건을 달성 } \\
\text { - 3년 연속 두 배 이상 성장해 2020년에 1,500억 원을 상회 }\end{array}$ \\
\hline & $\begin{array}{l}\text { neo } \\
\text { bazar }\end{array}$ & - 인도네시아의 웹툰, 웹소설 플랫폼 네오바자르를 인수 \\
\hline & \multicolumn{2}{|c|}{$\begin{array}{l}\text { - 2019년 11월 기준 전 세계 누적 다운로드 3,400만 건을 달성 } \\
\text { - 일본에서만 1,820만 건이 다운로드 }\end{array}$} \\
\hline & \multicolumn{2}{|c|}{$\begin{array}{l}\text { - 리디의 글로벌 웹툰 구독 서비스 만타(Manta)는 2020년 11월에 출시함과 동시에 구독모델 } \\
\text { 의 편익을 토대로 급성장 } \\
\text { - 미국 구글 플레이스토어 만화 앱 부분 1위(30만 이상 다운로드)를 차지 }\end{array}$} \\
\hline & \multicolumn{2}{|c|}{$\begin{array}{l}\text { - 독일, 호주, 마카오 구글 플레이에서 웹툰 매출 } 1 \text { 위를 차지 } \\
\text { - 회원수 } 350 \text { 만 명, 월간활성이용자수(MAU)는 } 150 \text { 만 명을 기록 } \\
\text { - 영어, 독어, 불어 등 프리미엄 번역을 통해 경쟁력을 발휘 }\end{array}$} \\
\hline 레진 코믹스 & \multicolumn{2}{|c|}{$\begin{array}{l}\text { - 미국과 일본 시장에 직접 진출해 영어로 } 219 \text { 작품, 일본어로 } 180 \text { 작품을 서비스 } \\
\text { - 해외 가입자가 } 585 \text { 만 명으로 미국 시장에서 2018년 } 105 \text { 억 원의 매출 기록, 일본에서는 } 37 \\
\text { 억 원으로 전년 대비 } 30 \% \text { 증가 } \\
\text { - 간접 진출한 중국 시장 실적까지 합하면 } 149 \text { 억 원으로 전년대비 } 52 \% \text { 성장 } \\
\text { - 프랑스 웹툰 플랫폼 기업 ‘델리툰’과 프랑스어와 한국어 웹툰 콘텐츠를 상호 번역 서비스하는 } \\
\text { 협약 체결 }\end{array}$} \\
\hline TOPTOON & \multicolumn{2}{|c|}{$\begin{array}{l}\text { - 중화권(대만 92편, 중국 330편), 일본 등 아시아 시장에 남성향 작품 서비스에 주력 } \\
\text { - 대만 유료 플랫폼 } 1 \text { 위를 기록하고 있으며 해외 가입자가 약 } 600 \text { 만 명에 도달 }\end{array}$} \\
\hline 투믹스 & \multicolumn{2}{|c|}{$\begin{array}{l}\text { - 2019년 해외 진출을 시작해 영어, 중국어, 스페인어, 이탈리아어, 포르투갈어, 독일어, 프랑 } \\
\text { 스어 서비스를 본격적으로 진행해 총 } 614 \text { 편을 서비스 }\end{array}$} \\
\hline
\end{tabular}


특히 카카오의 일본 진출 플랫폼인 픽코마는 2018년부터 괄목할만한 성장세를 보이 며 수익이 급증하기 시작했는데 2020년까지 3년 연속 2배 이상의 성장을 보였으며, 2020년에는 일본에서만 1,500 억 원 이상의 매출액을 기록18)하며 웹툰의 해외시장 수 익화를 본격적으로 진행하고 있다.

\section{다. 웹툰 해외진출에 있어서 현재의 시점: 아직 도입기에서 초성장기}

2021년 현재 상황은 2020년대의 초반에 해당하므로 국내 웹툰산업의 경우 성장기, 해외 웹툰산업의 진출면에 있어서는 아직도 도입기나 초성장기에 해당한다고 볼 수 있 다. 이렇듯 국내 웹툰산업과 해외 진출은 대체적으로 10 년의 시간차를 두고 있다. 국내 웹툰산업은 지속성장 후 향후 시간이 지나면 성숙기로 향하게 될 것이나 그 성장 정도에 따라 성장기가 더 오래 유지될 가능성도 높다. 그에 비해 해외 진출 측면에서 웹툰은 이제 막 글로벌 확장을 시작하는 도입기에서 성장기 초기국면에 위치해 있기 때문에 디 지털 만화시장 선점을 위한 적극적인 시장침투와 현지화가 필요한 시점이다.

[그림 2-4] 국내 및 해외에서의 웹툰산업의 수명주기 상 현재 위치

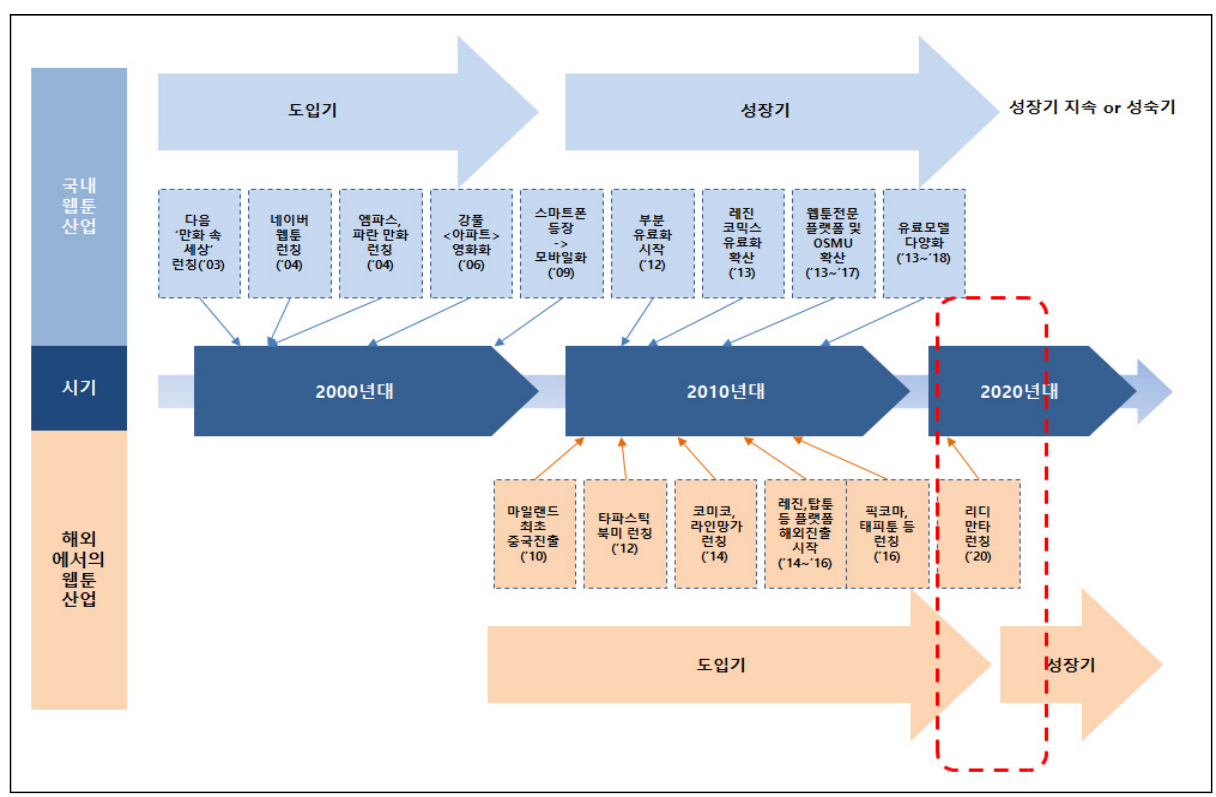

18) 매일경제(2020.11.09.), 카카오 픽코마, ㅂ 선전 덕에 전세계 만화앱 매출 1 위 


\section{제2절 웹툰산업 현황}

\section{1. 국내 웹툰산업 규모}

한국콘텐츠진흥원의 웹툰 사업체 실태조사에 따르면 국내의 웹툰 산업 규모는 2019 년 기준으로 6,400 억 원 규모로 전년(2018년 4,663억원) 대비 $37 \%$ 이상의 급성장이 이루어지고 있는 것으로 나타났다. 웹툰은 매년 30\% 이상의 성장을 보이며 콘텐츠업중 에서도 가장 가파른 성장세를 보이고 있다.

〈표 2-6〉 국내 웹툰산업 규모

(단위: 원)

\begin{tabular}{c|c|c|c}
\hline 구분 & 2017년 & 2018년 & 2019년 \\
\hline 플랫폼 & $242,206,987,049$ & $261,549,645,933$ & $387,411,632,641$ \\
\hline 에에전시 & $137,722,733,662$ & $204,793,140,000$ & $252,681,898,970$ \\
\hline 합계 & $379,929,720,711$ & $466,342,785,933$ & $640,093,531,611$ \\
\hline
\end{tabular}

자료: 2020 웹툰 사업체 실태조사, 한국콘텐츠진흥원(2020)

공급차원에서도 웹툰은 국내에서만 2003년에서 2019년까지 생산량 누적 1만 편을 달성하며 ‘한국 웹툰 1 만 편 시대’가 열리게 되었다. 웹툰 산업의 규모가 확대될수록 증 가하는 수요와 그에 맞는 공급의 증대로 인해 꾸준히 웹툰 수도 증가한 것이다. 웹툰 시장조사업체인 웹툰가이드에 따르면 2003년에 처음 제작된 웹툰은 37여 편에 불과했 지만, 2011년 들어 200여 편 넘게 생산되기 시작하였다. 포털사 뿐 아니라 다양한 윕툰 전문 플랫폼이 등장한 2015년부터는 년간 1,000 편 이상의 웹툰이 생산되어 현재까지 연 $1,000 ~ 1,500$ 여 편의 웹툰이 꾸준히 생산되고 있다. 
[그림 2-5] 연간 웹툰 생산량 및 누적량

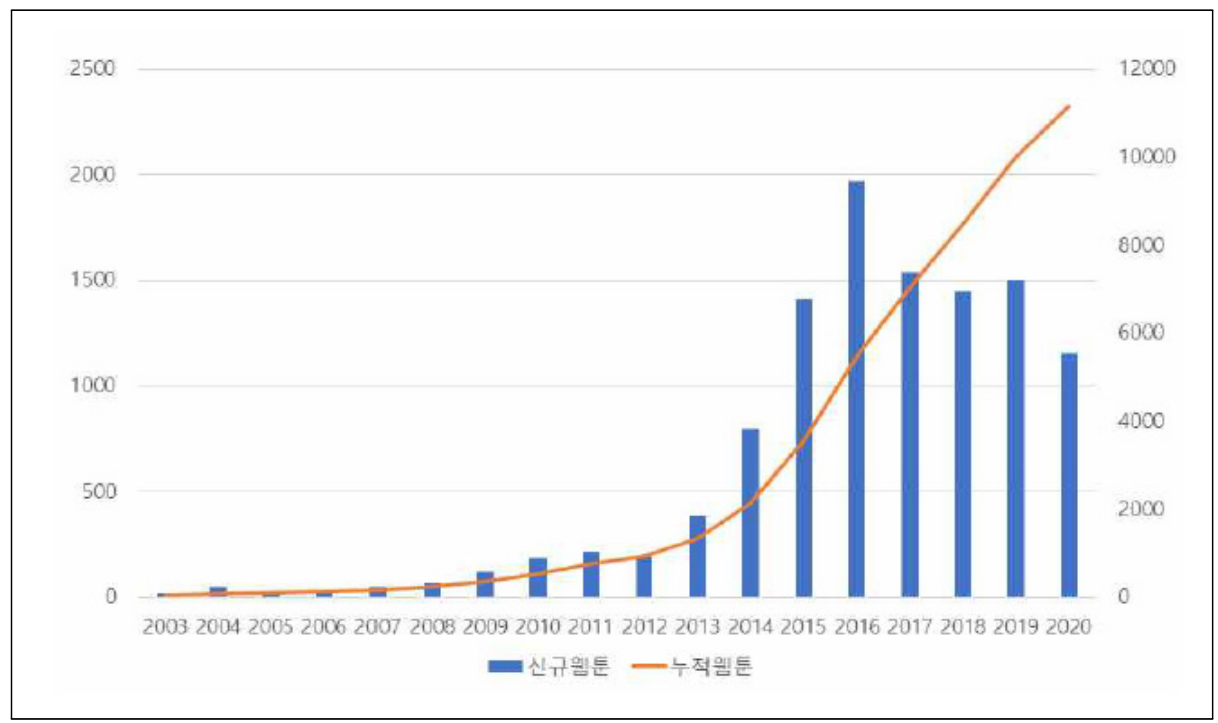

자료: 웹툰가이드 웹툰통계분석서비스 WAS

\section{2. 웹툰산업 주요 이슈 및 트렌드}

\section{가. 높아진 웹툰의 IP 가치}

글로벌 OTT를 중심으로 콘텐츠 IP 확보 경쟁이 치열해진 상황에서 웹툰은 핵심 IP 콘텐츠 자원으로 주목받고 있다. 글로벌 OTT인 디즈니플러스는 마블, $\mathrm{HBO} \mathrm{Max}$ 는 $\mathrm{DC}$ 코믹스, 넷플릭스는 밀러월드를 각각 자회사로 편입해 이들의 IP를 독점 콘텐츠로 제작 중에 있다. 이 중 넷플릭스는 『스위트홈』 등 웹툰을 원천 콘텐츠로 활용한 오리지 널 콘텐츠들을 다수 제작하였고, 글로벌 사업을 시작한 아이치이도 2021년 웹툰을 원천 콘텐츠로 활용한 작품인 『간 떨어지는 동거」를 오리지널 드라마로 공개 하였다.

모바일 인프라와 디지털 기기 보급의 확대로 SNS와 메시지 활용이 많아지고 있는 가 운데 웹툰은 이모티콘 활용에도 최적화된 콘텐츠이다. 이는 웹툰의 캐릭터를 큰 수정 없이 그대로 활용이 가능하여 OSMU에 용이하고, 웹툰을 활용한 이모티콘들은 초기에 는 독자들을 중심으로 구매가 일어나지만, 대화 상대방이 웹툰 독자가 아니더라도 알리 기에 용이하여 비독자로의 수요 확산가능성도 높다고 볼 수 있다.

게임에서도 웹툰의 캐릭터와 스토리를 활용한 게임이 제작되고 있다. 인기 있는 웹툰 
을 활용하여 게임을 제작하는 경우 원천 콘텐츠인 웹툰의 인지도와 완성도, 성공 요소들 을 기반으로 제작하여 실패 위험을 줄일 수 있는 등 유리한 측면이 있다. 뿐만 아니라 웹툰 개릭터는 문구용품이나 의류, 음식료 상품에도 활용되고 포장지나 광고 등에서도 적극 활용되고 있다.

〈표 2-7〉 웹툰의 IP 확장 사례

\begin{tabular}{|c|c|}
\hline IP확장 영역 & 사례 \\
\hline $\begin{array}{c}\text { OTा } \\
\text { (오리지널 영상콘텐츠) }\end{array}$ & $\begin{array}{c}\text { 넷플릭스: 〈킹덤〉, 〈스위트홈〉, 〈지금 우리 학교는〉, 〈승리호〉 등 } \\
\text { 아이치이:〈간 떨어지는 동거〉 등 }\end{array}$ \\
\hline 게임 & 〈덴마〉, 〈마음의 소리〉, 〈와라! 편의점〉, 〈삼국전투기〉, 〈신의 탑〉 등 \\
\hline 애니메이션 & 〈신의 탑〉,〈갓 오브 하이스쿨〉, 〈노블레스〉 등 \\
\hline 영화 & 〈부산행〉, 〈이끼〉, 〈신과 함께〉, 〈내부자들〉, 〈은밀하게 위대하게〉 등 \\
\hline 드라마 & $\begin{array}{c}\text { 〈타인은 지옥이다〉, 〈쌉니다 천리마트〉, 〈비질란테〉, 〈여신강림〉, 〈금수저〉, 〈내일〉, } \\
\text { 〈연의 편지〉, 〈피에는 피〉, 〈이태원 클라스〉, 〈미생〉 등 }\end{array}$ \\
\hline
\end{tabular}

$\mathrm{IP}$ 의 효과를 극대화하기 위해 독립적인 만화 콘텐츠 각 주인공들을 한 곳에 모아 세계 관으로 확장하는 세계관(Universe) 기획 전략이 웹툰에서도 시도되는 중이다. 디즈니의 자회사인 마블스튜디오는 마블 코믹스의 원작 만화를 바탕으로 영화 시리즈이자 영화 속 히어로 캐릭터들이 활동하는 세계관인 'MCU'를 구축하여 영화'어벤져스' 시리즈를 만들어 메가 히트를 친 바 있다. 어벤져스와 같이 네이버 웹툰도 ‘슈퍼스트링'이라는 세 계관 아래〈테러맨〉,〈부활남〉, 〈신석기녀〉, 〈신암행어사〉,〈버닝헬〉,〈하우스키퍼〉, 〈호러전파상〉 등의 작품을 제작하면서 세계관을 공고히 하고 모바일 게임을 시작으로 영상화로서 IP 확장을 모색을 시도하였다.

[그림 2-6] (좌)마블의 “MCU 세계관”과 (우)네이버웹툰 “Super String 세계관”

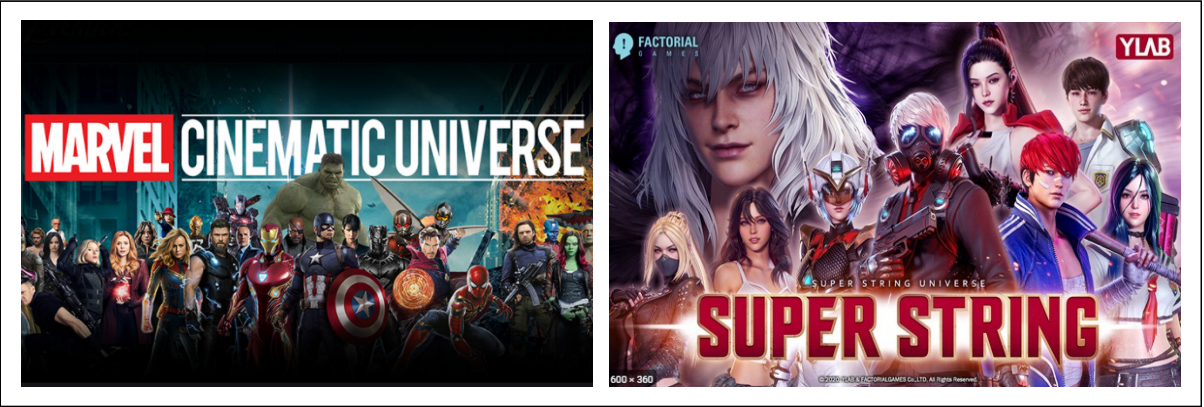

자료: 마블 홈페이지(https://www.marvel.com/), YLAB 홈페이지(http://www.ylabcomics.com/) 


\section{나. 웹툰 유통 다변화}

독립만화를 중심으로 소셜미디어(SNS), 크라우드 펀딩, 소규모 출판사, 오픈 플랫폼 등 대형 웹툰 플랫폼을 외 다양한 방식의 웹툰 유통방식들이 생겨나고 있다. 인스타툰은 대표적인 SNS인 인스타그램을 통해 장방형 10장의 이미지 형태로 구성된 만화형식으로 팔로워와 소통하며 팬덤을 형성하는 작가들이 등장하고 있다. 크라우드 펀딩을 통한 유 통방식도 생겨나고 있다. 소수자 서사 중심의 이야기를 중심으로 텀블벅 등의 크라우드 펀딩 플랫폼을 통해 모금되어 독립만화들이 배출되고 있다. 오픈 플랫폼에서도 웹툰이 유통되는데, $10 \%$ 내외의 낮은 수수료율로 작가 본인이 원하는 작품을 스스로 장작부터 연재, 홍보까지 담당하는 오픈 플랫폼 딜리헙과 포스타입이 시장에서 선전 중이다.

[그림 2-7] 인스타툰(좌)과 텀블벅의 웹툰 크라우드 펀딩(우)

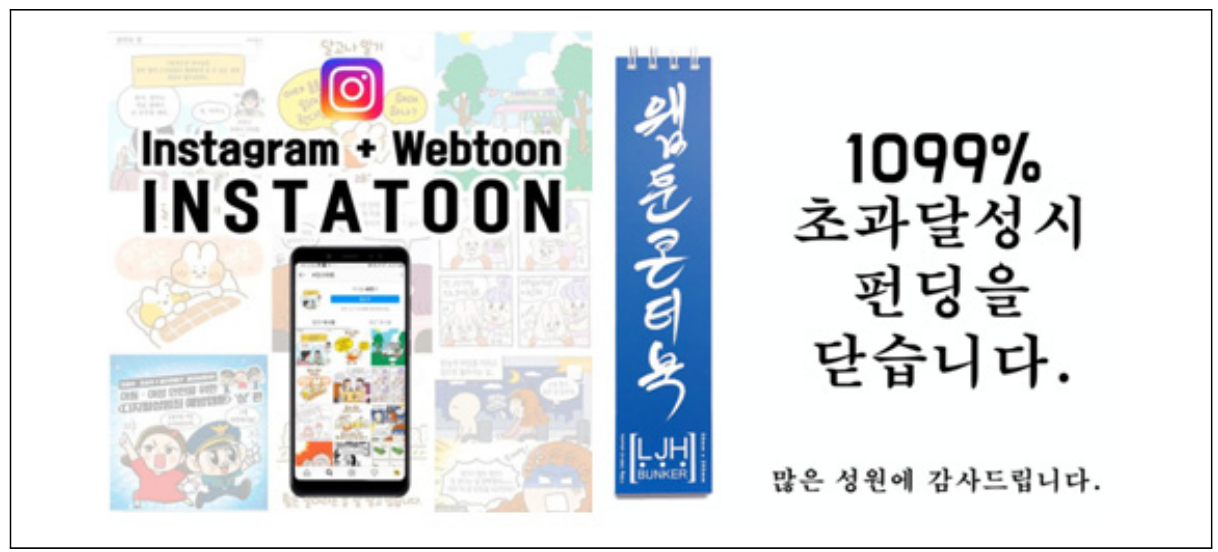

자료: 뉴스1, https://tumblbug.com/

\section{다. 여전한 불법 유통(저작권) 문제}

웹툰의 유료화가 시작한 순간부터 웹툰의 불법 유통은 함께 시작되었으며 현재까지도 가장 해결하기 어려운 난제로 자리하고 있다. 윕툰의 불법 유통업자들은 웹툰 콘텐츠가 유료로 공개된 공식 플랫폼에서 콘텐츠를 무단 복제하여 자신의 사이트에 공개하고, 해 당 페이지에 광고를 실어 불법적인 이득을 취한다. 가장 대표적인 웹툰 전문 불법 유통 사이트였던 “밤토끼’는 수년에 걸쳐 이와 같은 방식으로 수익을 취하다가가 2018년 5월 사이트가 폐쇄되고 운영자들은 검거되었다. 이에 업계에서는 불법유통이 일정 부분은 줄 
어들 것으로 기대했지만 밤토끼가 폐쇄되자마자 이를 대체하는 다른 유사 불법 유통사 이트들이 등장하였다. 그리고 웹툰 불법 사이트들의 페이지 수의 합은 2018년 3분기에 26.2억 뷰로 밤토끼가 폐쇄되기 전인 2018년 1분기의 26.8억 뷰의 수준으로 돌아갔으 며, 그 이후인 2018년 4분기부터는 오히려 증가하는 형태를 띠는 등 지속적으로 심각한 문제를 야기하고 있다. 특히 이들 불법 웹툰 유통 사이트들은 국내에서 사이트를 운영하 지만 서버는 국내가 미국에 두어 국내 법망을 피했으며, 성인물이나 불법 도박 사이트들 의 광고로 규모를 키웠다. 웹툰 분석서비스 업체 WAS에 따르면 이들 웹툰 불법 유통사 이트들의 페이지뷰 수는 2019년 2분기만 38억 2,000만 뷰로, 연간 피해액이 2조 원 이상인 것으로 추산된다.

[그림 2-8] 불법 웹툰 유통사이트의 페이지 뷰수 추이

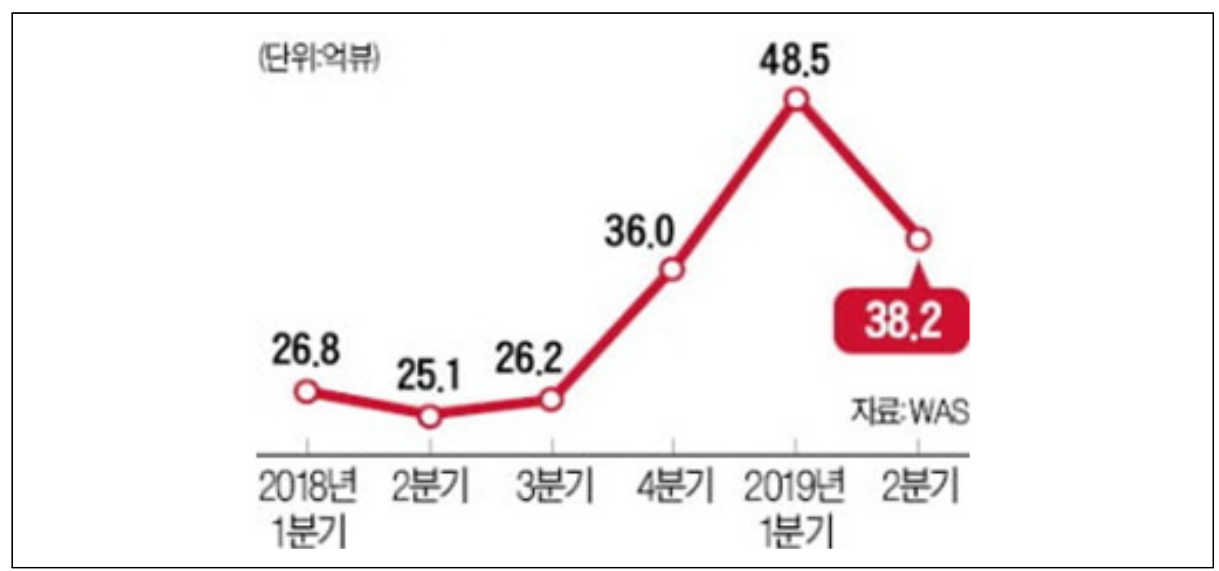

자료: WAS, 한국경제(2019)

\section{라. 웹소설 원작 웹툰 콘텐츠의 활성화/제작의 스튜디오화}

웹툰 제작에 대규모 자본이 투여되면서 에이전시가 점차 제작사의 성격을 띠기 시작 하고 되었다. 에이전시는 개별 작품의 저작권 '대행, 중계'에서 작품 '기획-개발' 단계로 나가며 웹툰 제작에 필요한 여러 인력들을 직접 고용하거나 자회사를 설립하는 방향으 로 전문화되고 있다. 이는 개인 작가들과 계약을 맺어 작품을 개발하는 기존 비즈니스 모델에 더해 내부 스튜디오를 운영하고, 내부 스튜디오 운영은 인력을 고용하기 때문에 법적으로 저작권을 제작사가 보유하는 것이 가능하다.

에이전시의 제작 참여 경향은 웹소설 원작 웹툰이 성공하면서 본격적으로 확산되었는 
데 카카오페이지의 노블 코믹스가 크게 성공하고, 뒤이어 네이버웹툰이 웹소설 원작 웹 툰에 뛰어들면서 에이전시들은 적극적으로 웹툰 제작에 참여하고 있다. 웹소설 원작 웹 툰 제작은 제작사를 중심으로 웹소설 IP를 확보하고 콘티 작가와 그림 작가를 영입하는 방식으로 이루어지는데, 웹소설 원작 웹툰은 2015년 카카오페이지가 노블코믹스라는 브랜드로 서비스하며 상업적으로 성과를 냈다. 웹소설 원작 웹툰이 런칭 초기 수익을 극대화하기 위해서는 웹소설 독자를 웹툰으로 유입하고 결제를 유도하기 위해 미리보기 형태로 많은 회차가 있어야 한다는 특성이 있다. 따라서 개인 작가보다는 대부분 자금을 보유한 제작사를 중심으로 개발을 진행해야 되며 이 과정에서 웹툰 제작 단계는 더욱 세분화, 전문화 된다.

[그림 2-9] 웹소설 기반 스튜디오 시스템으로 만들어진 웹툰 예시

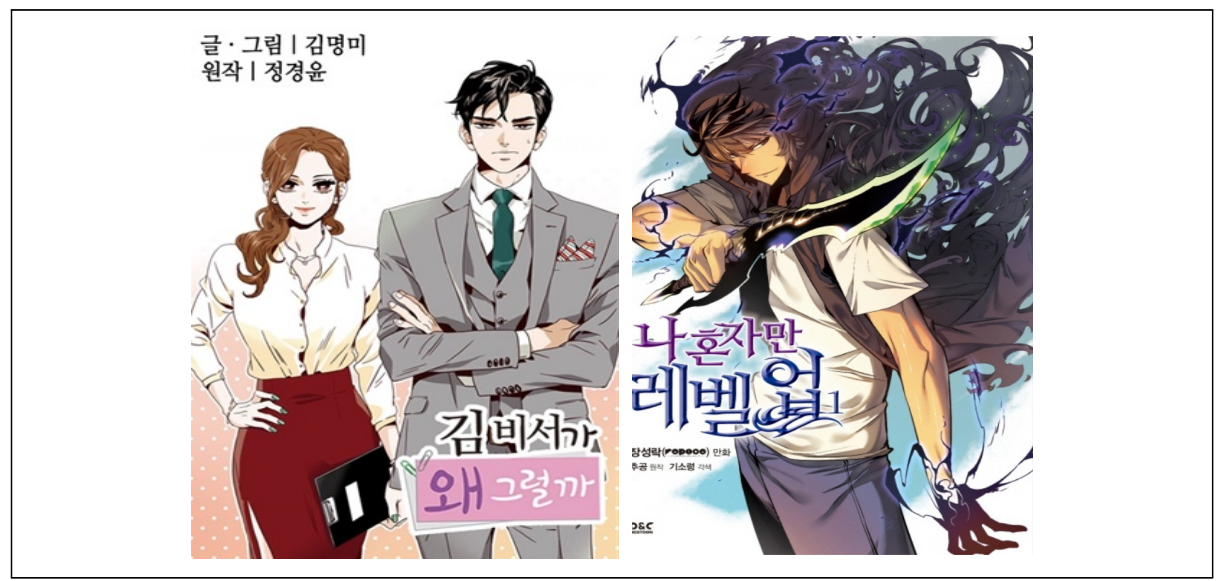

자료: 카카오페이지 홈페이지(https://page.kakao.com/)

최근에는 에이전시라는 용어와 제작사라는 용어가 혼재되어 사용될 정도로 적극적으 로 웹툰 IP를 보유하려 하고 이를 활용하여 제작에 나서고 있다. 인지도 있는 에이전시 는 대부분 기획·개발 직원을 채용하거나, 내부 스튜디오를 운영하는데 웹툰 IP의 기획 이후 오리지널 웹툰을 창작하거나 아니면 웹소설을 원작으로 하는 웹툰을 창작하는 식 으로 운영된다. 오리지널 웹툰은 스토리 작가나 작화 작가가 콘티를 만들지만, 웹소설 원작웹툰은 각색 작가가 콘티까지 담당하며, 작화 작가는 작화와 컬러링을 모두 진행하 기도 하지만, 대규모 자본이 투여되고 제작 퀼리티가 중시되면서 컬러 작업은 별도의 작가나 팀으로 분리되는 경우가 많아지며 전문화되고 세분화된다. 


\section{마. 현지화를 위한 창작시장 개척}

웹툰의 해외진출이 본격화되면서 현지화를 위한 노력도 계속되고 있다. 네이버는 한 국의 창작만화 게시판 '도전만화'를 글로벌 시장에 적용한 아마추어 창작공간플랫폼 'Canvas'를 글로벌 시장에서 운영하고 있다. 네이버는 해외 진출 초기부터 국가별 자생 적인 수급 체계를 고민하여, 웹툰을 홍보하고 각 국가 신인 작가 유입을 장려하고 있다. 최근 전세계 아마추어 창작자들 70 여만 명이 모이면서 전세계 대규모 창작 생태계를 형 성하고 있는데 'Canvas'의 미국 전체 작가 평균 연수익은 6천만 원, Top 10 작가평균 연수익은 5억원에 달하며 Canvas를 통해 웹툰 작가에 입문하기 위해 하루 1 천 개 이상 의 에피소드가 올라오고 있다.

현지 스타작가 발굴 시례도 있다. 북미 누적 조회수 2 억 5 천만 뷰, 글로벌 누적 조회 수 5억 6천만뷰 이상을 기록하고 있는 ‘로어올림푸스’의 작가 ‘레이첼스마이스(Rachel Smythe)'는 'Canvas'를 통해 네이버 웹툰이 발굴한 미국 현지 작가에 해당한다. 2018 년부터 네이버 글로벌 웹툰 플랫폼 라인웹툰에서 연재 중인 ‘로어올림푸스'는 그리스 신 화라는 서구적 세계관을 기반으로 하며, 프랑스어 및 스페인어로 번역되어 유럽이나 중 남미에서도 높은 인기를 구가하고 있다. 2019년 미국 만화계의 아카데미상으로 불리는 '아이즈너어워드'의 후보에 올랐으며, 미국의 유명 제작사인 짐헨슨컴퍼니(The Jim Henson Company)와 TV 애니메이션 제작을 계약하였다. 이처럼 자유로운 창작자의 데뷔시스템과 보상체계가 적용된 북미지역'Canvas'에서 연재되는 작품수는 연평균 $108 \%$ 씩 바르게 증가하는 중이다.

〈표 2-8〉 네이버 웹툰 미국/스페인 top 10에서의 현지작품 강세

\begin{tabular}{c|c|c|c|c|c}
\hline 국가 & 순위 & 제목 & 장르 & 작가 & 작가 국적 \\
\hline \multirow{7}{*}{} & 1 & Lore Olympus & 로맨스 & Rachel Smythe & 현지 \\
\cline { 2 - 6 } & 2 & Let's Play & 로맨스 & Mongie & 현지 \\
\cline { 2 - 6 } & 3 & 여신강림 & 드라마 & 야옹이 & 한국 \\
\cline { 2 - 6 } & 4 & SubZero & 로맨스 & Junepurrr & 현지 \\
\cline { 2 - 6 } & 5 & unOrdinary & 판타지 & uru-chan & 현지 \\
\cline { 2 - 6 } & 6 & Freaking Romance & 로맨스 & Snailords & 현지 \\
\hline & 7 & I Love Yoo & 로맨스 & Quimchee & 현지 \\
\cline { 2 - 6 } & 8 & Cursed Princess Club & 코미디 & LambCat & 현지 \\
\hline
\end{tabular}




\begin{tabular}{c|c|c|c|c|c}
\hline 국가 & 순위 & 제목 & 장르 & 작가 & 작가 국적 \\
\hline \multirow{7}{*}{} & 9 & Age Matters & 로맨스 & Enjelicious & 현지 \\
\cline { 2 - 6 } & 10 & Siren's Lament & 로맨스 & instantmiso & 현지 \\
\hline \multirow{5}{*}{ 스페인 } & 1 & 여신강림 & 드라마 & 야옹이 & 한국 \\
\cline { 2 - 6 } & 2 & Lore Olympus & 로맨스 & Rachel Smythe & 현지 \\
\cline { 2 - 6 } & 3 & Age Matters & 로맨스 & Enjelicious & 현지 \\
\cline { 2 - 7 } & 4 & 스위트홈 & 스릴러 & 김칸비/황영찬 & 한국 \\
\cline { 2 - 6 } & 5 & Freaking Romance & 로맨스 & Snailords & 현지 \\
\cline { 2 - 6 } & 7 & Mi secreto más íntimo & 드라마 & Hanza Art & 현지 \\
\cline { 2 - 6 } & 8 & El lamento de la sirena & 로맨스 & instantmiso & 현지 \\
\cline { 2 - 7 } & 9 & Consejos sentimentales del gran duque & 코미디 & unfins & 현지 \\
\cline { 2 - 6 } & 10 & infernal & 판타지 & Color_LES & 현지 \\
\hline
\end{tabular}

자료: 네이버 웹툰 영문(https://www.webtoons.com/en/), 스페인어(https://www.webtoons.com/ep/) 페이지 


\section{제3절 웹툰산업의 사업방식}

\section{1. 웹툰의 비즈니스적 가치와 유망성}

\section{가. 온라인·모바일로 전환된 콘텐츠 소비방식 변화}

대부분의 콘텐츠 산업들은 인터넷과 모바일의 시대를 거치면서 디지털 매체 환경에 맞추어 그 소비방식도 전환되고 있다. 온라인 기반 디지털 콘텐츠 소비가 일반화되면서 국경을 초월한 초대형 글로벌 플랫폼이 등장하고 네트워크 효과(network effect)를 토 대로 글로벌 콘텐츠와 소비자를 흡수하면서 해외진출의 주된 유통경로로 자리매김하게 됨에 따라 장르별 소비 형태도 변화하고 있다. 음악은 음반/공연에서 음원/온라인 공연, 게임은 콘솔에서 $\mathrm{PC} /$ 모바일 게임, 드라마는 방송국에서 $\mathrm{VOD} / \mathrm{OTT}$, 영화는 영화관에 서 $\mathrm{VOD} / \mathrm{OTT}$ 로 각각 사업영역을 확장하는 중이다. 이러한 방식은 언제 어디서나 콘텐 츠의 소비가 가능하며, 소비자 접점 역시 확대되는 방향으로의 변화이다.

〈표 2-9〉 콘텐츠 장르별 글로벌 주도 플랫폼

\begin{tabular}{c|c}
\hline 장르 & 주도 글로벌 플랫폼 \\
\hline 방송·영상 & 넷플릭스, 유튜브 \\
\hline 음악 & 스포티파이, 애플뮤직 \\
\hline 게임 & 스팀, 에픽게임즈 스토어 \\
\hline e북 & 아마존 킨들 \\
\hline
\end{tabular}

웹툰의 경우에도 기존의 디지털 스캔을 통한 기존 출판만화 형식의 포맷은 가독성이 매우 떨어진다는 점에서 모바일에 최적화된 웹툰의 형식은 익숙해지면 그 파급력이 매 우 높다. 글로벌 만화시장에서 디지털 만화가 차지하는 비중은 30\% 수준이며, 이 역시 전체 만화 시장의 절반을 차지하는 일본의 디지털화가 이뤄지면서 전환되고 있는 상황 이고 다른 국가들의 디지털 비중은 아직까지 매우 낮다. 문화체육관광부에 따르면 전 
세계 디지털만화 시장은 2019년에서 2023년까지 연평균 5.9\%로 성장해 33억달러(한 화 3.6조원) 규모를 형성할 것으로 추정되며 디지털만화가 전체 만화시장(디지털+인쇄) 에서 차지하는 비중은 2021년을 기점으로 최초로 $50 \%$ 돌파가 될 것으로 파악되고 있 다. 또한, 이미 정교하게 구성된 모바일 앱을 통해서 전 세계에서 접속, 결제, 열람 과정 이 간편하게 구성되어 있는 상황이다.

[그림 2-10] 글로벌 디지털 만화 시장 규모

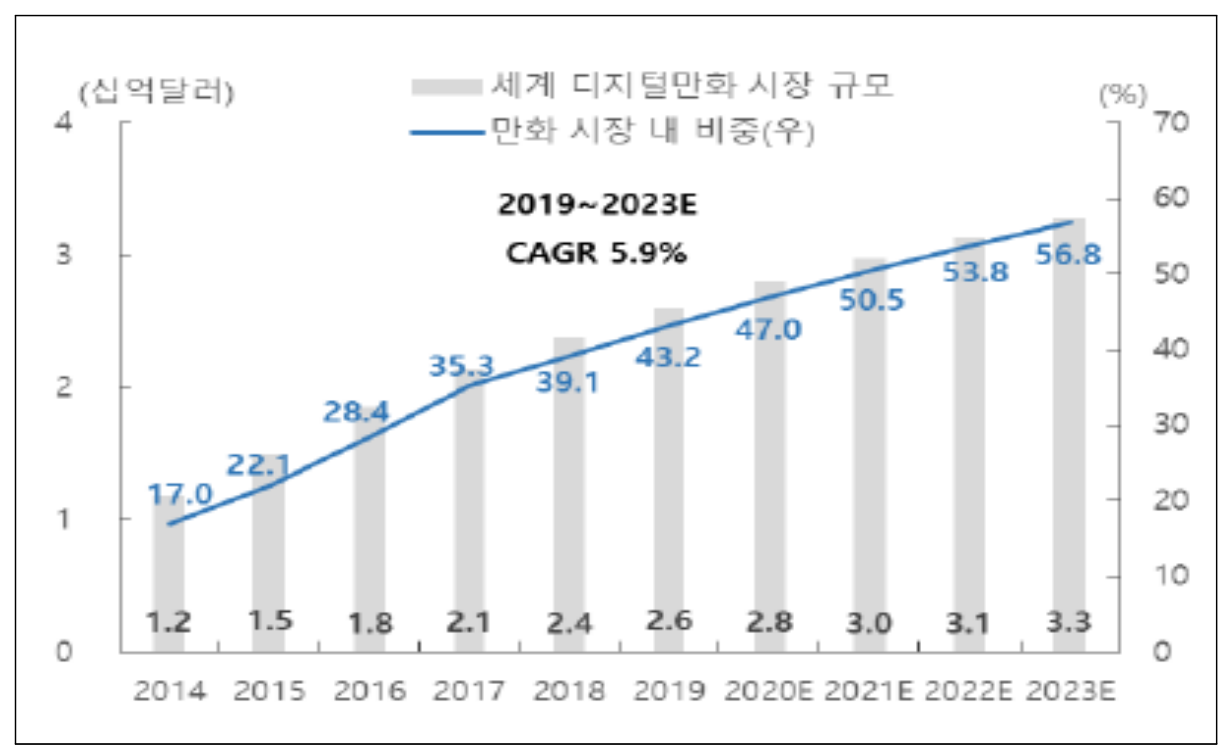

자료: 문화체육관광부(2020)

\section{나. $\mathrm{MZ}$ 세대가 선호하는 디지털 콘텐츠}

$\mathrm{MZ}$ 세대는 언제 어디서나 간편히 즐길 수 있는 스낵처럼 출퇴근의 이동시간이나 점심 시간 등 짧은 시간 안에 쉽게 즐길 수 있는 콘텐츠를 선호하는데, 웹툰, 웹 소설, 웹 드라 마 등 짧은 호흡의 콘텐츠들이 최근에 큰 인기를 끌고 있다. 긴 콘텐츠는 자투리 시간에 끝까지 보기 부담스럽고 누구나 손에 들려 있는 스마트폰을 활용한 모바일 최적화 플랫 폼을 통한 소비가 일반화되어 가고 있다. 특히 다른 세대에 비해 유독 MZ세대에 인기를 끌고 있는 솟폼 동영상 플랫폼인 틱톡의 인기도 이러한 성향을 반영한다.

장기적으로 $\mathrm{MZ}$ 세대가 웹툰에 충성도를 가지고 성장하여 구매력이 높은 층으로 성장 하게 될 때, 향후 유료서비스 이용자로 전환될 가능성은 높다. 웹툰은 이용 빈도수가 높 
은 대표적인 콘텐츠로 서비스 이탈률이 낮아 유료 이용률이 하락할 가능성은 제한적이 다. 특히 MZ세대는 모바일 트래픽 발생에 핵심계층일 뿐 아니라 향후 구매력이 계속 증가하며, 글로벌 웹툰 시장 성장의 핵심기반이 될 가능성이 높다.

[그림 2-11] 네이버 웹툰 국가별 구독자 연령 비중

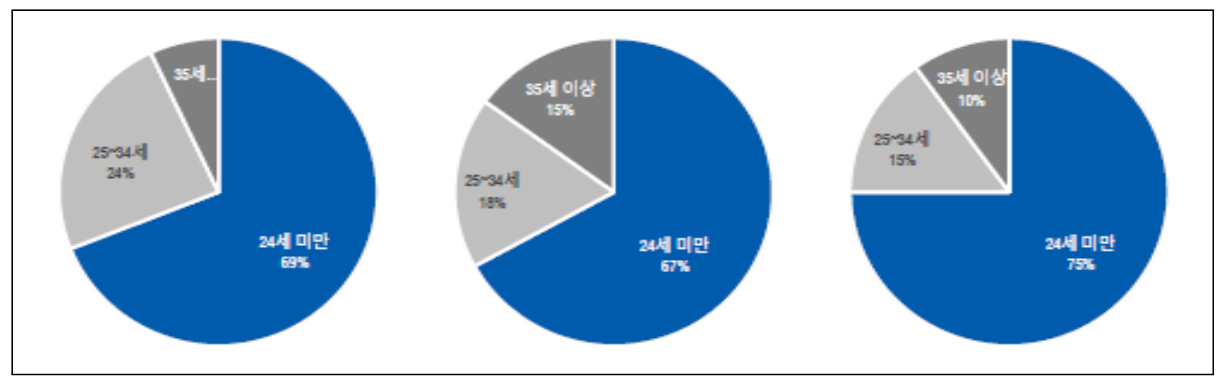

자료: 네이버

주: 왼쪽부터 미국, 멕시코, 프랑스

\section{다. 플랫폼 선점효과와 풍부한 제작 자원}

우리나라가 웹툰 종주국이라는 점은 향후 장점이 될 수 있다. 기존의 만화생산이 일본 과 미국의 만화 등 일부 국가들에 편중되어, 각국 현지인들에게 소구될 수 있는 현지 만화콘텐츠의 양은 절대적으로 부족하였다. 이에 비해 한국은 다양한 장르별로 만화 콘 텐츠가 풍부해 기존 만화시장과 별개의 새로운 시장 창출이 가능하다. 웹툰 종주국인 한국의 네이버, 카카오가 글로벌 웹툰시장의 생태계를 조성하고 시장을 선점하였는데 이 는 유튜브, 넷플릭스 초기와 같이 시장을 선점하는 효과를 불러올 수 있다. 웹툰 플랫폼 의 자생적 생태계는 유튜브의 지난 10 년과 유사하며 이용자 증가는 장기 지속될 가능성 높다. 유튜브의 경우에도 판매 수익을 분배한 것이 신규 크리에이터 유입을 불러왔고, 신규 크리에이터 유입은 콘텐츠 퀄리티를 상승시켰으며 높은 퀼리티의 콘텐츠는 다시 신규 유저를 유입시키는 선순환구조를 낳았다.

웹툰의 빠른 제작기간과 창작성은 타 국가에서 모방하기 어려운 경쟁력을 지녔다. 1 주일이라는 짧은 주기 동안 50 100컷 규모의 고품질 컬러 만화 콘텐츠를 생산해내기 위해서는 작가의 역량뿐 아니라 정교한 시스템이 필요하다. 우리나라에는 다양한 스튜디 오 및 에이전시가 존재하고 기획, 제작, 유통 과정이 발전된 웹툰 산업의 경쟁력을 짧은 시간 타국에서 쫒아오기 어려운 차별성을 지니고 있다. 


\section{라. 제작비 리스크가 상대적으로 낮은 비즈니스}

웹툰은 작가 원고료와 작업비용을 제외하면, 상대적으로 고정 비용이 적다는 점에서 제작비 리스크가 낮은 비즈니스이다. 출판만화 시대엔 인쇄·제본비용도 크게 차지했었지 만, 웹툰의 경우엔 그러한 비용도 사라졌다. 적은 제작비를 투입해 많은 IP들을 생산할 수 있어, 상상을 통해 무한하고 새로운 시도가 가능하다. 따라서 제작비가 상대적으로 매우 낮은 웹툰을 통해 작품성이 있는 이야기임을 검증한 뒤에 단일 제작비 리스크가 큰 드라마, 영화, 게임, 애니메이션, 뮤지컬 등으로 활용이 용이하다고 볼 수 있다.

\section{마. 원천콘텐츠(IP)로의 가치와 OSMU 용이성}

웹툰의 흥행으로 인해 대중성을 검증받은 콘텐츠 IP는 영화나 드라마와 같은 다른 장 르로 확장되었을 경우 흥행 가능성을 높게 평가받을 수 있다. 미국 시장의 1 2위 만화기 업인 마블과 DC코믹스는 출판만화를 통해 축적한 IP를 기반으로 라이선싱, 영화/드라 마 제작 등 OSMU 사업을 통해 부가가치를 창출한다.

웹툰은 기본 스토리와 플롯이 콘티의 형식으로 이미 나와 있는 콘텐츠라 영상화가 수 월하고 독자의 충성도가 높다. 웹기반 콘텐츠의 특성상 스토리가 신선하고 소재가 매우 다양한데, SF나 환타지물의 경우 세계관이 이미 생성되어 있는데다 특수효과 등 디지털 기술의 발달로 다양한 신규스토리 생성 및 영상화가 수월하다. 기존 미디어채널이 온라 인, 모바일로 확산되면서 채널 즉, 콘텐츠 수요자를 계속 늘리는데 비해 스토리를 생산 할 작가는 현실적으로 제한적이다.

최근 국내외 OTT 플랫폼 간 오리지널 콘텐츠 경쟁이 치열한 상황에서 웹툰은 이미 1 만 여개의 이야기를 가지고 있는 콘텐츠 IP 창고라고 볼 수 있다. 국내의 다양한 드라 마와 영화들이 웹툰 IP를 기반으로 영상화되 성공을 거두었다. 여기에 승리호, 스위트홈, 이태원 클래스 등 넷플릭스와 같은 글로벌 플랫폼을 통해서 전 세계적으로 웹툰 기반 영상 콘텐츠가 인기를 끌자 전 세계적인 주목과 수요가 몰리고 있다. 


\section{2. 웹툰산업의 비즈니스 모델}

웹툰 산업은 시장에 도입된 2003년 이래로 현재까지 꾸준히 진화했으며 그 발전과정 마다 비즈니스 모델도 정교하게 발전해왔다. 특히 초기 무료로만 콘텐츠를 제공했던 트 래픽 확보시기에서 2010년대 들어 광고 모델을 적용한 판매 및 광고 수익 창출모델이 개발되었으며, 2013년부터 해외진출이 시작되면서 글로벌 시장도 비즈니스 모델에 포 함되기도 하였다. 그리고 2010년대 중반 이후에는 웹툰을 원천으로 활용하여 부가적 비 즈니스를 창출하는 IP 활용범위 확대 모델이 본격화되었다. 이러한 비즈니스 모델의 등 장을 시기별로 펼쳐보면 [그림 2-12]과 같다.

[그림 2-12] 웹툰산업 비즈니스모델 발전 과정

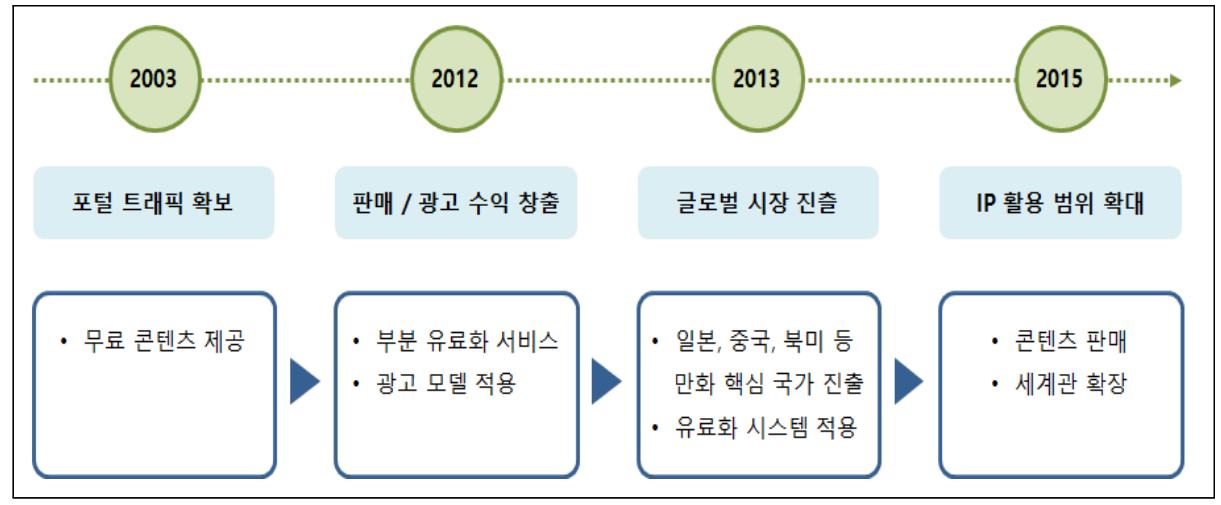

\section{가. 포털의 트래픽 확보를 위한 무료 콘텐츠}

\section{1) 서사웹툰 연재로 트래픽을 보한 '다음'}

2000년대 초반 대형 포털의 트래픽 확보 경쟁이 시작되면서 웹툰은 포털 유입을 위한 서비스 목적으로 활용되었다. 2003년 당시 포털 사이트 다음은 한메일 서비스를 시작하 며 야후코리아를 이기고 포털 1 위로 올라서게 된다. 이후 뉴스 섹션에 '만화 속 세상'이 라는 채널을 개설해 디지털 만화의 유료 서비스와는 별도로 웹툰을 제공했다. 회차마다 끊어지는 이야기로 연재되던 기존의 디지털 만화와는 달리. 강풀의 〈순정만화〉나 강도 하의 〈위대한 캣츠비〉등과 같은 드라마 형식의 서사웹툰이 폭발적인 인기를 끌게 되었 고 자연스럽게 트래픽 확보로 이어졌다. 특히 당시 강풀의 〈순정만화〉가 히트를 치게 
되면서 기존 디지털 만화와 같은 옴니버스 형식이 아닌 서사성을 가진 네러티브 형식의 장편 웹툰의 성공 가능성이 증명되었다.

또한 사용자들 간의 커뮤니티 성격이 강했던 다음은 '나도 만화가'라는 서비스를 만들 어 사용자들이 직접 유입할 수 있을뿐더러 신진 만화가들의 등용문이 되도록 했다.

다음은 정식 연재 작가들에게 원고료를 지급했고, 사용자들에게 무료로 웹툰을 제공 하는 대신 광고를 함께 노출하는 사업모델을 택했다. 이렇게 창출된 광고 수익까지 작가 들과 나눔으로써 웹툰의 비즈니스 모델을 확장하기 시작했다.

[그림 2-13] 포털 다음의 초기 웹툰서비스 ${ }^{19)}$

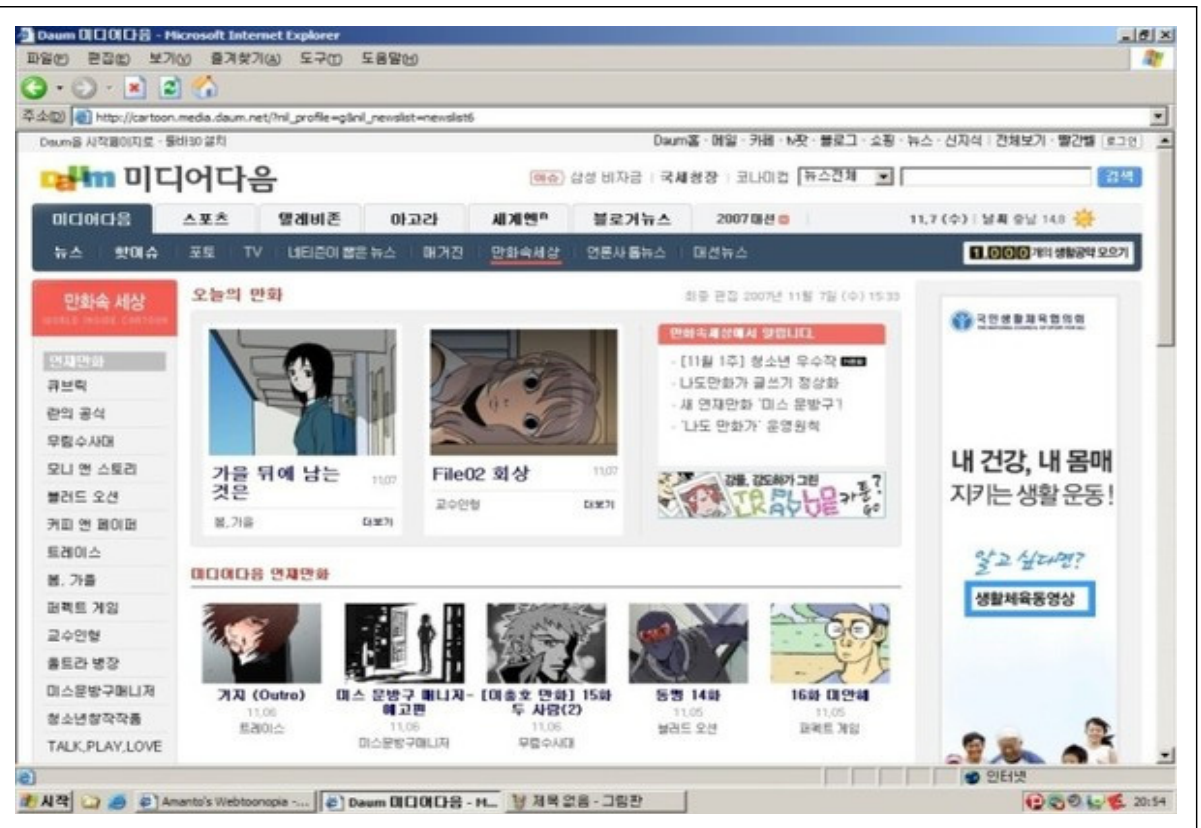

\section{2) 유머코드와 일상소재를 활용해 트래픽을 증가시킨 '네이버'}

2004년 지식인 서비스를 제공하며 포털 트래픽 1위를 달성하며 다음의 독주를 막은 네이버가 이를 기회로 삼아 만화 서비스 제공까지 확장하게 된다. 네이버는 다음과 달리 ‘만화’라는 통합 서비스 섹션에 웹툰을 제공했고, 일상 소재나 유머 코드를 가진 작품을 통해 이용자를 확보했다. 당시 다음에서 기성작가 연재와 긴 서사의 스토리 작품이 많았

19) 테크M, [같이봐영] 20년 역사 '다음웹툰' 아듀! 영광의 기록들(feat.카카오웹툰) (2021.08) 
던 상황에서 네이버는 신진작가, 유머를 바탕으로 한 옴니버스 작품, 기존에 접하지 못 했던 독특한 장르를 구성해 기존에 다음에서 보지 못했던 작품들을 디스플레이하기 시 작한다. 그 중 조석의 〈마음의 소리〉, 김규삼의 〈입시명문사립 정글고〉등이 흥행에 성공 하면서 2009년 다음과 네이버 웹툰의 월 평균 방문자 수는 400만 명과 800만 명을 기 록해 네이버 웹툰이 독점적 위치에 오르게 된다. 이후 〈치즈인더트랩〉, 〈가우스 전자〉, 〈신과함께〉 등 서사성을 담은 콘텐츠들까지 연달아 성공하며 네이버 웹툰의 독주가 시 작된다.

또한 네이버는 다음의 웹툰 서비스를 벤치마킹하여 요일별로 특정 작품을 연재하는 '요일제 시스템'을 적용해 매일 트래픽이 고르게 분배될 수 있는 전략을 구축했으며, 동시 에 '베스트 도전 만화' 서비스를 구축해 누구나 웹툰 작가가 될 수 있는 기회를 주는 대신 ‘승급제'라는 차별화 전략을 세워 정식 연재 작가가 될 수 있도록 단계를 체계화 했다.

이렇게 다음과 차별화된 전략으로 대량의 트래픽을 정기적으로 유발해낸 네이버 역시 광고 노출을 통해 수익을 올리는 사업 모델을 구축하게 되었다.

[그림 2-14] 포털 네이버의 초기 웹툰서비스20)

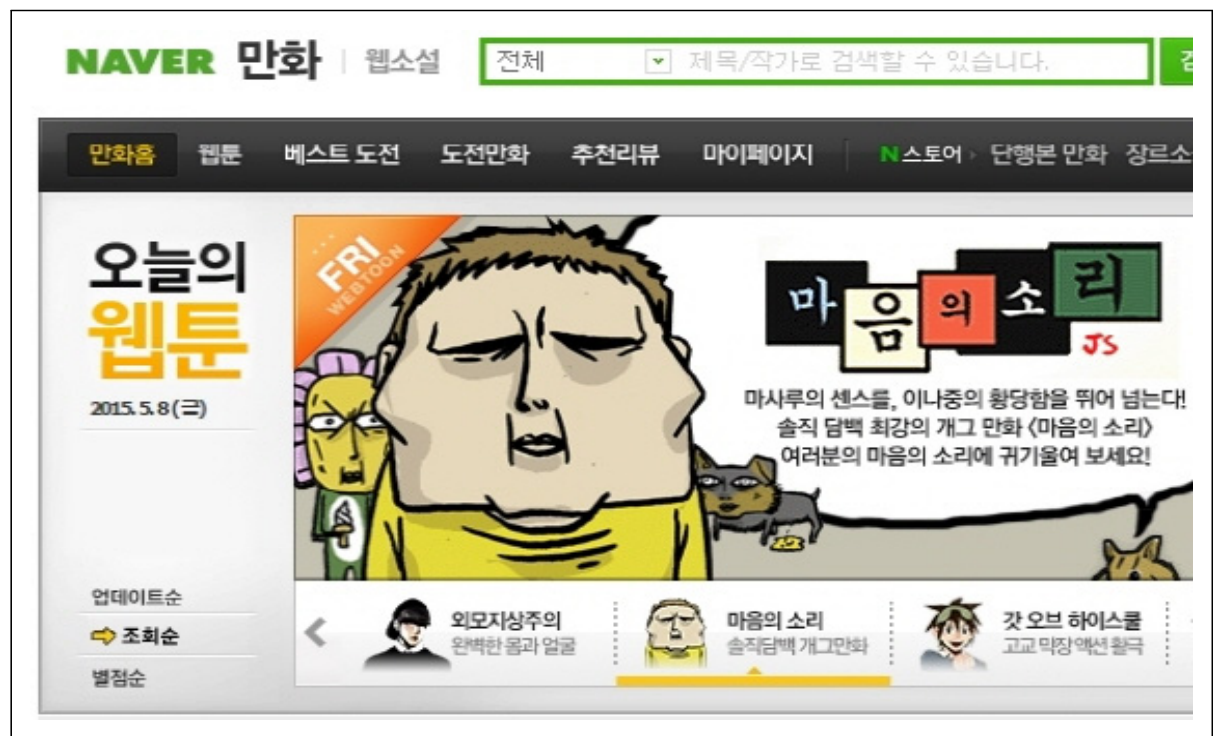

20) 미디어펜, 외모지상주의·연애혁명..네이버웹툰 성공비결은 '경쟁' (2015.05) 


\section{나. 부분 유료화와 광고를 통한 수익 창출}

\section{1) 유료 서비스 도입과 웹툰 전문 플랫폼의 등장}

웹툰 서비스의 가치가 상승되며 2012년 대형 포털을 중심으로 부분 유료화 시스템이 도입된다.

대표적인 웹툰 플랫폼 네이버 웹툰과 다음 웹툰은 연재 중인 작품의 미공개 회차를 미리 볼 수 있는 '미리보기'와 연재가 완결된 작품을 다시 볼 수 있는 '완결보기' 방식의 유료 서비스를 도입해 그 수입을 창작자와 나누는 비즈니스 방식을 택했다. 이러한 유료 서비스 도입에 대한 우려의 목소리도 있었으나, 유료보기 월 매출만 9억이 넘는 작품이 탄생하는 등 다양한 작품의 수익이 증가됨에 따라 웹툰 콘텐츠의 자생력이 상승되었다 는 것을 증명하게 되었다. 그 외에도 네이버 웹툰에서 제공한 〈송곳〉, 〈신과함께〉, 〈오렌 지 마말레이드〉, 〈치즈인더트랩> 등 10 편 내외의 작품들이 '유료 보기' 서비스를 통해 매출 1억 원 이상 달성하며 유료보기 서비스가 주요 수익 모델로 자리 잡기 시작한다.21)

무료 웹툰을 중심으로 제공하던 포털과는 달리. 작품 판매에 대한 수익으로 시스템 운영에 집중하는 유료 웹툰 플랫폼이 등장한다. 대표적인 유료 웹툰 플랫폼 레진코믹스 는 작품의 초반부를 무료로 감상하고, 이후 회차는 가상 코인을 구입해 구독하는 방식의 부분 유료화를 시도해, 특히 성인 중심의 독자층을 확보하며 유료 서비스 시장에 안착하 게 된다. 이러한 레진코믹스의 성공으로 신생 웹툰 플랫폼들이 빠르게 시장에 진입하며 유료 서비스를 더욱 고착화 시켰다.

'미리보기', '완결보기'와 같은 단순 유료 서비스 이후, 초반 회차만 무료로 공개하고 그 이후 회차는 유료화하는 '일부편 공개 후 무료', 유료 회차 이후 정해진 기간동안 기 다리면 1회차 씩 무료로 공개되는 '기다리면 무료', 완결된 유료 웹툰 중 하루마다 무료 로 1 회차 씩 공개하는 ' 24 시간마다 무료', 추천 작품을 감상하면 유료 웹툰을 볼 수 있는 캐시를 지급해주는 '감상하고 캐시', 2 일을 기다리면 1회를 무료로 볼 수 있는 '2일마다 1 회 무료, 유저 맞춤형 콘텐츠 및 이벤트 추천으로 일부 유료 작품을 무료로 제공해주 는 ‘너에게만 무료' 등 유료화 모델을 더욱 다양화해 운영하고 있다.

21) 머니투데이, 웹툰 하나로 한달 매출 9억원? ..."짭짤하네" (2016.02) 
〈표 2-10〉 웹툰의 유료화 모델

\begin{tabular}{|c|c|}
\hline 유료화명 & 내용 \\
\hline 일부편 공개 후 무료 & $\begin{array}{c}\text { 첫 편이나 5화까지의 콘텐츠를 무료로 공개하고 그 이후에 } \\
\text { 대해서는 유료화 }\end{array}$ \\
\hline 완결 후 유료 & 연재가 완결된 작품을 대상으로 유료화 \\
\hline 미리보기 유료 & $\begin{array}{c}\text { 공개된 연재분 이후의 } 5 \text { 편 정도의 연재분에 대해서 } \\
\text { 유료로 지불할 시 미리 볼 수 있도록 함 }\end{array}$ \\
\hline 기다리면 무료(미리보면 유료) & 유료 회차 이후 (1주일)기다리면 1회차씩 무료로 풀리는 유료화 모델 \\
\hline 24시간마다 무료 & $\begin{array}{c}\text { 완결된 일부 유료웹툰 일부에 하루마다 무료로 1회차씩 제공하는 } \\
\text { 유료화 모델 }\end{array}$ \\
\hline 너에게만 무료 & $\begin{array}{l}\text { 맞춤형 콘텐츠 및 이벤트 추천으로 고객 맞춤형으로 } \\
\text { 일부 유료 작품을 이벤트성으로 무료로 제공 }\end{array}$ \\
\hline
\end{tabular}

\section{2) 정교화된 광고 서비스}

웹툰의 유료 서비스가 도입되고 수익 모델이 구축됨과 동시에 웹툰 플랫폼들은 광고를 통한 새로운 수익 모델을 구축하게 된다. 스마트폰의 보급이 활발해지고 웹툰 플랫폼이 어플리케이션(app)화 됨에 따라 다양한 구좌에서 자연스럽게 광고를 노출할 수 있는 방 식들을 개발한다. 광고는 크게 두 가지 유형으로 구분할 수 있는데, 콘텐츠가 노출되는 인터페이스 지면을 활용하는 광고와 웹툰 콘텐츠 자체를 활용하는 광고로 나눌 수 있다.

웹툰의 지면을 활용한 가장 전통적이고 기본적인 광고는 막대모양의 광고를 삽입하는 ‘배너광고(디스플레이 광고)’이다. 웹툰 광고의 시초이자 가장 많이 판매되고 있는 광고 의 플랫폼은 당연 네이버웹툰이다. 네이버웹툰의 초기 배너광고는 콘텐츠를 다 감상한 후 가장 하단에 붙인 '빅배너' 유형이 일반적이었으나, 현재 모바일앱(mobile-app) 기 반과 모바일웹(mobile-web) 기반, 그리고 PC윕(PC-web)에 따라 광고 유형을 달리 한 다. 모바일앱 실행 시 메인 작품 리스트 화면 하단에 띠배너 형태로 화면에 고정되어 노출되는 '앱띠배너', 모바일웹 실행 시 홈 메뉴 및 요일 별작품 리스트 페이지 중단에 노출되는 '웹DA' 상품이 있으며, $\mathrm{PC}$ 에서 웹툰 이용 시 메인 영역과 정식 연재 작품 원 고 하단에 띠배너로 노출되어 마우스 오버 시 이미지 확대 또는 동영상이 확장되는 형태 의 '트리플플레이' 배너 광고가 있다. 이러한 배너 광고들은 작가와 작품에 관계없이 플 랫폼 지면 자체에 노출되는 광고이므로, 풀랫폼과 광고주 사이에서 직접적인 비즈니스로 발생되고 있다. 
[그림 2-15] 네이버 웹툰 배너 광고 집행 프로세스

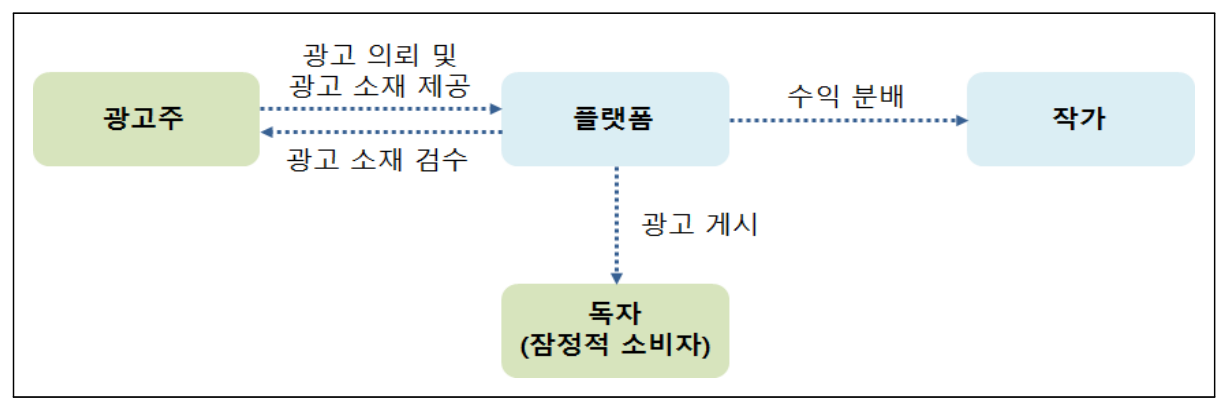

[그림 2-16] 네이버 웹툰의 배너 광고 상품22)

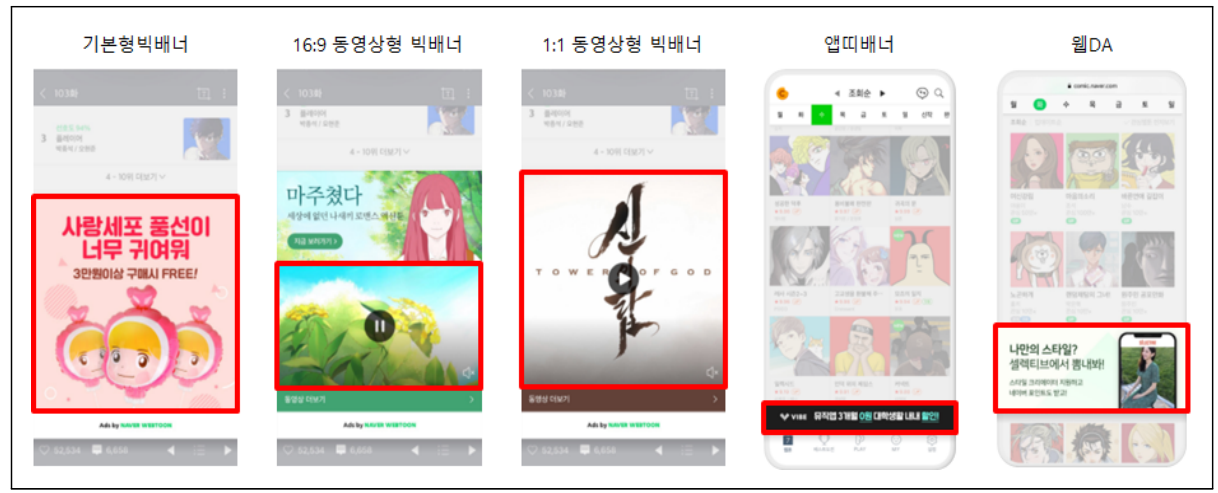

웹툰 콘텐츠 자체를 활용하는 광고 중 가장 대표적인 광고는 브랜드 웹툰이다. 브랜드 웹툰이란 웹툰의 재미요소를 활용하여 브랜드 스토리를 전달하는 광고로, 광고하고자 하 는 제품이나 소구하고자 하는 메시지를 웹툰 속에 스토리로 자연스럽게 노출하여 이용 자들로부터 거부감 없이 긍정적인 반응을 유도한다. 브랜드 웹툰의 시초라고 할 수 있는 한화케미칼의 〈연봉신〉은 주인공이 한화케미칼에 입사해 겪는 직장생활을 스토리로 풀 어내 높은 조회수와 화제성을 낳으며 시즌제로 연재되었고, 다음 해 신입사원 공채 지원 자가 1.5 배 이상 늘어나는 등의 브랜드 인지도를 높였다는 점에서 대표적인 성공사례라 고 할 수 있다. 또한 해태제과의 〈퍼스트 스위트〉도 남녀의 사랑 이야기를 해태제과의 제품들에 빗대어 자연스러운 스토리로 표현해 기업의 주가가 상승하기도 했다. 또한 현 재 주식시장에서 $\mathrm{MZ}$ 세대가 주요 고객으로 떠오르며 $\mathrm{MZ}$ 세대를 겨냥하는 마케팅 활동으 로 브랜드웹툰이 각광을 받고 있으며, 유진투자증권은 유명 작가 '자까'와 함께 손을 잡

22) 네이버 디스플레이 광고 내 ‘웹툰광고’ (https://displayad.naver.com/advertisement/webtoon) 
고 브랜드웹툰 〈신입일기〉를 연재하며 네이버 웹툰 전체에서 2위를 차지할 정도로 큰 인기를 얻고 있다.23) 이러한 브랜드웹툰은 광고주가 최초로 광고를 의뢰할 때 플랫폼에 게 별도에 매체비와 구좌비를 지급하고, 희망하는 창작자(웹툰 작가)를 선택한 뒤 에이 전시를 통해 원고 제작비를 지급하는 형태로 진행되어 '창작자 $\leftrightarrow$ 웹툰 광고주 $\leftrightarrow$ 매체자 $\leftrightarrow$ 창조적 사용자 $\leftrightarrow$ 사용자 광고주’라는 구조가 형성되어 운영되고 있다.

[그림 2-17] 네이버 브랜드 웹툰/PPL 집행 프로세스

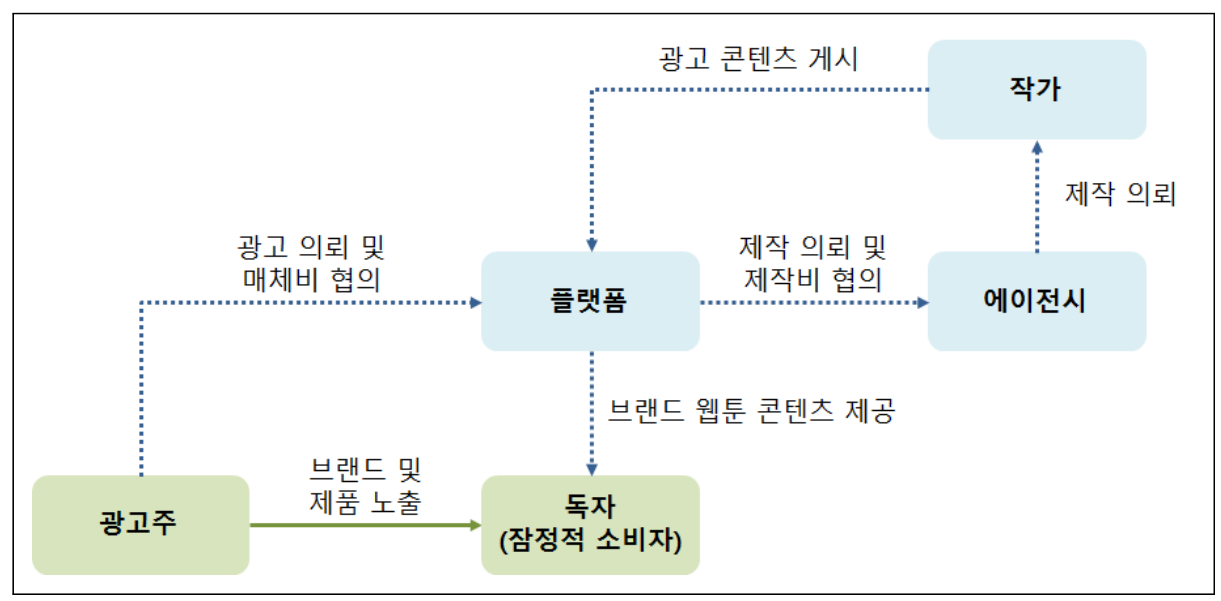

[그림 2-18] 네이버 웹툰 전체 2위까지 달성한 유진투자증권의 브랜드 웹툰24)

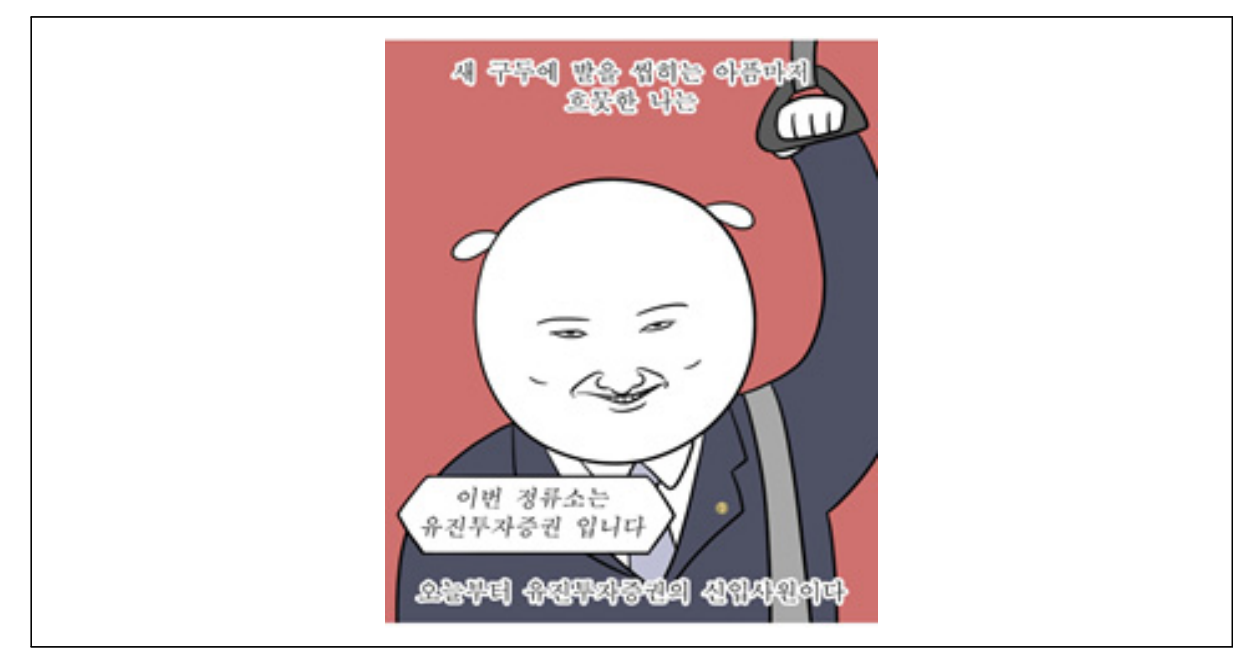

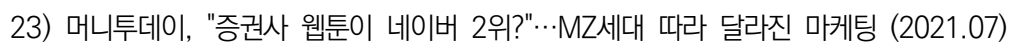

24) 뉴데일리, "MZ세대 잡아라" $\cdots$ 유진투자증권, 네이버웹툰 등판 (2021.06) 
이렇게 유료화 서비스가 점차 진화되고 웹툰 인터페이스 내 광고 지면이 더욱 다양화 되면서 웹툰을 통해 광고하고자 하는 기업들을 대상으로 플랫폼 내 가상화폐를 활용한 새로운 광고가 등장하기 시작한다. 대표적인 웹툰 플랫폼 네이버는 '쿠키’를 활용해 사 용자가 직접 충전하는 형태의 가상화폐로 사용되고 있으며, 다음 역시 '캐시'를 통해 가 상화폐를 운영 중이다. 각각의 플랫폼들은 광고하고자 하는 브랜드와 제품의 이미지를 배너광고 형식으로 노출하고 "알림 받기 하면 쿠키 3개 증정”, “팔로우 하면 쿠키 2개 증정”과 같이 광고주가 제안한 미션을 수행할 시 리워드 형식으로 가상화폐를 증정하는 광고를 집행하고 있다.

[그림 2-19] 네이버웹툰과 카카오웹툰의 가상화폐 리워드형 광고25)

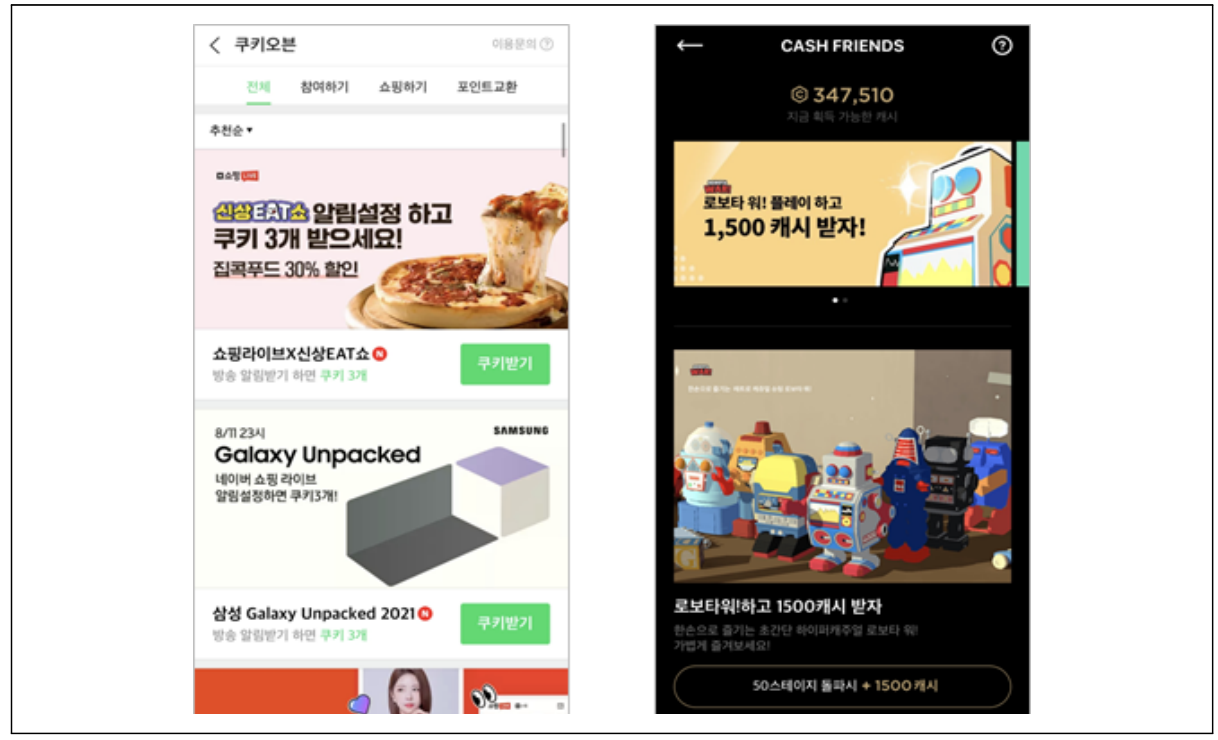

웹툰 광고 서비스 중 인터페이스 지면과 웹툰 콘텐츠 자체를 모두 활용하는 광고가 있다. 바로 PPL이다. PPL은 Product Placement의 약자로, 말 그대로 콘텐츠에 제품 을 배치한다는 것을 뜻하는데, 주로 방송 프로그램 등에 소품으로 등장시켜 홍보할 제품 이나 브랜드를 노출시키는 형태의 광고이다. 이러한 PPL은 웹툰 광고에도 적용되어 광 고하고자 하는 브랜드나 제품을 콘텐츠 내에 자연스럽게 배치시킨다. 웹툰 PPL에는 연 재 중인 작품의 스토리 안에 광고하고자 하는 제품을 자연스럽게 배치해 노출하는 '삽입

25) 네이버웹툰 App 내 ‘더보기-쿠키오븐’ 페이지와 카카오웹툰 App 내 'CASH FRIENDS' 페이지 
형 PPL'과 연재중인 작품 하단에 작가의 작화를 활용한 광고 소재를 노출하는 '이미지형 PPL'이 있다. 이러한 웹툰 PPL은 브랜드웹툰과 마찬가지로 광고주가 플랫폼에게 별도 에 매체비와 구좌비를 지급하고, 창작자(윕툰 작가)를 선택한 뒤 PPL 사용료를 지급하여 '창작자 $\leftrightarrow$ 웹툰 광고주 $\leftrightarrow$ 매체자 $\leftrightarrow$ 창조적 사용자 $\leftrightarrow$ 사용자 $\leftrightarrow$ 광고주’라는 구조로 운영된다.

[그림 2-20] 독자들에게 긍정적 호응을 얻은 굽네치킨의 조석 〈마음의 소리〉 PPL ${ }^{26)}$

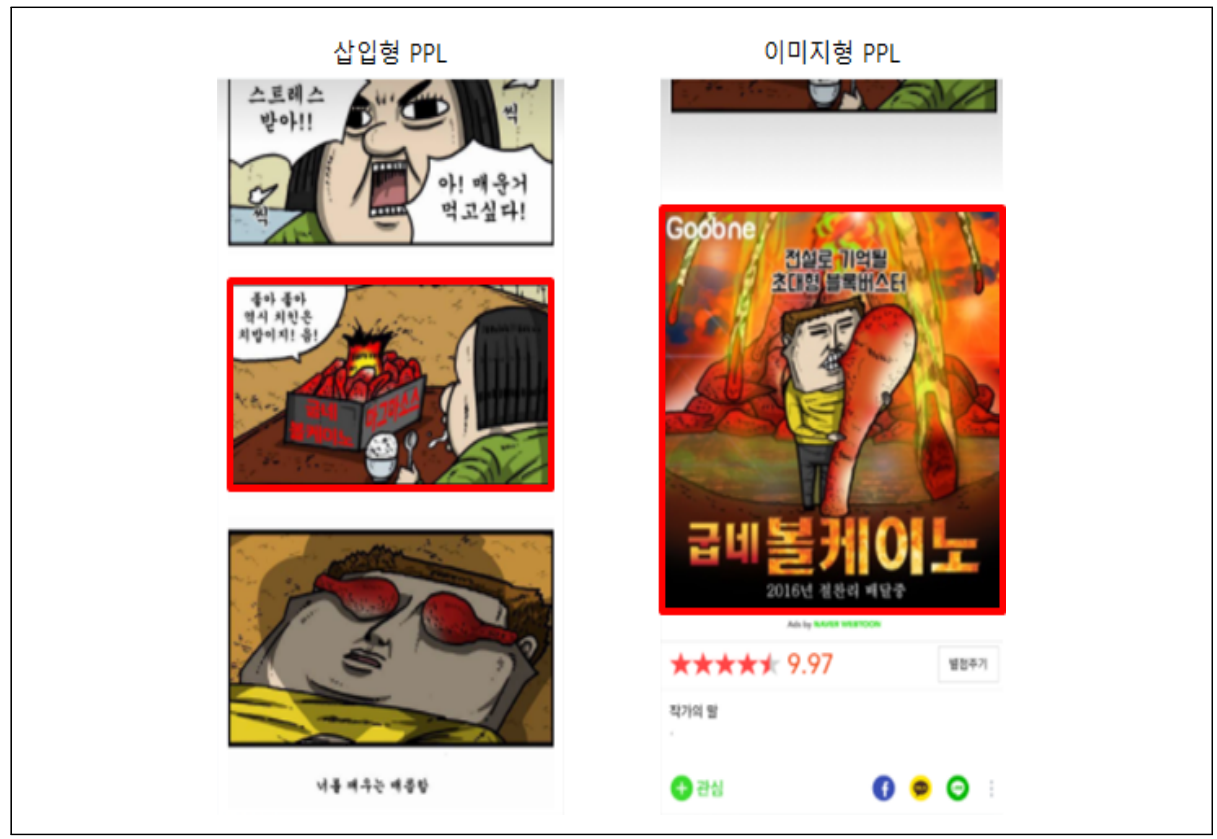

위와 같이 웹툰 플랫폼 내 광고를 통한 수익구조가 점점 더 고도화되면서 플랫폼들은 광고주와 플랫폼, 그리고 사용자들 모두가 만족하는 새롭고 흥미로운 방식의 광고 상품 을 계속해서 개발하는데 집중하고 있다.

\section{다. 글로벌 진출을 통한 서비스 영역의 확장}

1) 대형 포털의 해외 진출

국내 웹툰 산업의 수익구조가 구축되고 작품성을 인정받는 웹툰 IP들이 증가되면서 점차 해외로 비즈니스 영역을 넓히게 된다. 가장 먼저 해외 진출에 눈을 돌린 것은 네이

26) 네이버 디스플레이광고 내 '웹툰광고-PPL' (https://displayad.naver.com/advertisement/webtoon) 
버 웹툰이었다. 국내 웹툰 시장의 주도권을 잡고 있던 네이버는 2014년 '라인웹툰'을 런칭하고 일본과 대만, 미국, 태국에 진출, 2015년 인도네시아에 이어 2019년 유럽과 남미까지 진출한다.27) 이러한 네이버 웹툰이 글로벌 시장을 선점하면서 동남아 주요 국 가에서 네이버웹툰의 월간 이용자 수(MAU) 인도네시아 690만, 태국 350만, 대만 150 만을 달성하고 세 나라에서 사용자 1 위를 차지하기도 했다. 또한 북미 시장에서도 월간 이용자 수 1000 만 명을 달성하며 2 년간 평균 $71 \%$ 성장하는 등의 성과를 바탕으로 2020년 5월 한국의 네이버웹툰과 미국 웹툰엔터테인먼트, 일본 라인디지털프론티어로 나뉘어있던 기업들을 미국 웹툰엔터테인먼트로 통합해 글로벌 웹툰 시장으로서의 입지 를 단단히 했다.28)

네이버는 2014년 영어 콘텐츠를 시작으로, 2019년 스페인어와 프랑스어 등 다양한 언어로 번역해 서비스하고 있다. 이는 기존 한국 콘텐츠를 글로벌 시장에 맞는 언어로 번역하여 제공한 것이다. 현재 국내에서 흥행하고 있는 대표적인 웹툰 콘텐츠인 야옹이 작가의 〈여신강림〉의 번역본이 미국 현지에서 Top 3 를 기록하며 미국 시장에서도 한국 웹툰 콘텐츠의 위상이 점차 높아지고 있다.29)

또한 네이버는 한국에서 성공적인 반응을 얻은 '도전만화' 시스템을 북미 시장에 맞춘 '캔버스(Canvas)'를 구축해 도입했으며, 캔버스를 통해 그 작품수가 연평균 108\%씩 증 가하는 추세를 보여 아마추어 작가의 등용문 역할을 하고 있다.30) 이렇게 캔버스 시스템 을 통해 발굴된 대표적인 작가 레이첼 스마이스(Rachel Smythe)의〈러브 올림푸스 (Love Olympus)>가 북미 현지 시장에서 누적 조회 수 2억 5,000만 뷰, 글로벌 누적 조회 수 5억 6,000만 뷰를 기록하며 1위를 달성해 흥행에 성공하였고, 2020년 11월 국내 네이버웹툰에서도 정식 연재되기 시작하였다.31) 이렇듯 네이버는 글로벌 시장 확 장을 통해 수익성 개발은 물론, 국내외 작가들의 해외 진출 기회의 장을 더욱 확대시켜 활동의 영역을 넓히는 역할을 하고 있다.

네이버 웹툰과 마찬가지로 다음 웹툰 역시 글로벌 시장 진출을 본격화하였다. 다음은 북미 지역을 해외 시장 진출의 교두보로 삼아 타파스미디어와 전략적 제휴를 맺고 북미

27) 한경 비즈니스, 네이버 vs 카카오, 달아오르는 웹툰 전쟁 (2021. 06월호)

28) 뉴데일리경제, 네이버 vs 카카오... 글로벌 '웹툰' 시장 놓고 한판승부 (2021.06.14.)

29) 미래에셋대우 리서치센터, NAVER - 네이버웹툰, 2020년 글로벌 성장세 또 확인 (2020.02)

30) 한경 비즈니스, 네이버 웹툰, 미국 찍고 글로벌 공략 개시 (2020. 07월호)

31) 매일일보, 네이버웹툰, 북미 1위 웹툰 '로어 올림푸스' 19일 국내 첫 공개 (2020.08) 
최초의 웹툰 포털 업체인 타파스틱을 통해 5편의 웹툰을 정식으로 출시하게 하였다.32) 이어 중국의 대표 포털 사이트인 텐센트의 '큐큐닷컴'과 중국 최조의 만화 사이트 'U17 (요우치)', 중국 모바일 콘텐츠 플랫폼 '열독기지', 웹툰 어플리케이션 '미람만화 앱’ 등 중국을 대표하는 인터넷/모바일 콘텐츠 플랫폼 4곳에 웹툰 작품 40 여 개를 선보이며 중국 시장에 진출하였다.33)

다음은 카카오와의 합병에 따라 다음 웹툰을 카카오페이지에 동시 연재하며 시너지를 낼 수 있는 운영 방법을 선택한다. 2016년 다음카카오는 해외 진출을 위해 일본 시장을 선택하고, 일본 현지법인인 카카오 재팬을 통해 웹툰 서비스 '픽코마’를 시작한다. 웹툰의 유료화 서비스 중 하나인 '기다리면 무료' 서비스와 같은 한국 웹툰 플랫폼에서 사용된 비즈니스 모델을 카카오 재팬에 그대로 구현해 일본 시장에 성공적으로 안착했다. 또한 〈나 혼자만 레벨업〉, 〈이태원 클라쓰〉등 카카오페이지에 연재된 인기 웹툰들을 일본 현 지에 맞게 번역하여 제공해(〈이태원 클라쓰〉를 〈롯본기 클라쓰〉로 변역하는 등) 2016년 판매액 약 15억원을 시작으로 2017년 240억원, 2018년 620억원, 2019년 1,140억원, 2020년 4,146억원의 매출액을 기록하며 일본 시장에서 맹활약하고 있다.34)

\section{2) 웹툰 전문 플랫폼의 해외 진출}

2013년부터 서비스를 시작해 가장 먼저 유료 서비스를 성공적으로 안착시킨 웹툰 전 문 플랫폼 레진코믹스는 2015년 유료 비즈니스 모델을 그대로 도입해 일본과 미국 시장 에 진출한다. 레진코믹스는 대형 포털들의 해외 진출 방법과는 달리, 하나의 플랫폼에서 한국어, 일본어, 영어로 언어와 국가를 변경하면 해당 국가 서비스의 메인으로 이동하게 되는 단일 플랫폼을 이용해 글로벌 서비스를 제공하고 있다. 2015년 일본 후지 TV에서 방영된 인기 드라마 '메꽃, 평일 오후3시의 연인들' 을 웹툰으로 미디어트랜스하여 제작 해 한국와 일본 시장에서 연재35)하고, 2017년 북미 최대 애니메이션 축제인 '애니메엑 스포'에 참가해 현지에서 인기가 높았던 스릴러물 〈킬링스토킹〉과 뱀파이어 판타지물 〈블러드 뱅크〉의 작가들이 현지 팬들과 만나는 사인회도 성황리에 마무리되는 등36) 해

32) 연합뉴스, 네이버-다음, '웹툰' 글로벌 시장 진출 본격화 (2014.08)

33) iT매일, 다음 웹툰, 중국 3대 콘텐츠 플랫폼과 손잡고 본격 진출 (2015.04)

$34)$ 한국경제, 매출 0 원 $\rightarrow$ 하루 40 억 $\cdots$ 애니 본고장 日 '웹툰'으로 뜷은 카카오 (2021.07)

35) 아시아경제, 레진코믹스, 일본 드라마 '메꽃, 평일 오후3시의 연인들' 웹툰 제작 (2015.09)

36) 브릿지경제, 레진코믹스, 북미 최대 애니메이션 축제 ‘애니메 엑스포 2017’ 참가 (2017.07) 
외 시장에서 웹툰 플랫폼으로서의 입지를 넓혀갔다.

이후 2020년 월 평균 400만 명 이상의 이용자를 보유한 북미시장 영어권 최대 만화 플 랫폼 '아니메 플래닛(anime planet)' 과 파트너십을 맺고 해당 플랫폼에 최대 10회차 분량 의 영어 웹툰을 무료로 공개한 뒤 추가 회차는 레진 플랫폼을 이용하도록 해 신규 고객 확 보를 유도하고 있다. 또한 일본시장에서 아무타스가 운영하는 일본 최대 규모의 웹 만화 플랫폼인 '메챠코믹'과 '코믹 시모아', '렌타', '코미코', '픽코마' 등과 함께 파트너십을 맺 고 서비스 중인 웹툰을 재유통하고 있으며, 중화권 플랫폼인 '콰이칸, '빌리빌리'. 프랑스 웹툰 플랫폼 '델리툰'과 파트너십을 맺어 해외 시장 유통망을 확대해 나가고 있다.37)

남성 이용자를 주요 타겟으로 운영되고 있는 탑툰은 2015년 대만을 시작으로, 2017 년 일본에서 '탑망가(IOPMANGA)'라는 이름으로 서비스되고 있다. 탑툰은 국내 운영 전략과 동일하게 남성향 콘텐츠를 주로 서비스하며 대만에서 라인웹툰에 이어 2 위를 차 지해 2016년 말 300만 달러 이상의 매출을 달성하기도 했다.

그 외 코미코(NHN), 리디만타, 태피툰, 투믹스와 같은 윕툰 플랫폼들 모두 본격적으 로 해외 시장에 진출하고 있다.

\section{라. IP를 활용한 수익 모델의 확장}

1) 콘텐츠 $I P$ 의 확장

이용자들로부터 웹툰 콘텐츠의 흥행성과 작품성을 인정받으면서 웹툰 외 다양한 플랫 폼과 다양한 방법으로 콘텐츠의 확장이 이루어진다.

〈은밀하게 위대하게〉, 〈이끼〉, 〈이웃사람〉 등 작품성을 인정받은 웹툰을 중심으로 콘 텐츠의 원천 스토리를 소재로 한 영화나 드라마들이 등장하면서 웹툰 콘텐츠의 멀티 장 르화 현상이 나타난다. 네이버 웹툰의 대표 작품인 조석의 〈마음의 소리〉는 2016년 애 니맥스 채널의 애니메이션으로 방송되었을 뿐만 아니라 네오위즈의 캐주얼 게임으로도 서비스되었으며, $\mathrm{KBS} 2$ 드라마로도 방영된다. 이와 같이 하나의 컨텐츠 소스에서 시작된 2차 콘텐츠들이 3차, 4차 콘텐츠로 그 범위가 넓어지면서 웹툰의 OSMU가 각광받기 시작한다.

37) 아이뉴스24, 해외로 뻗는 '레진'...美·日 웹툰 유통채널 강화 (2020.11) 
[그림 2-21] 웹툰을 원작으로 제작된 영화 〈은밀하게 위대하게〉,〈이끼〉, 〈이웃사람〉38)
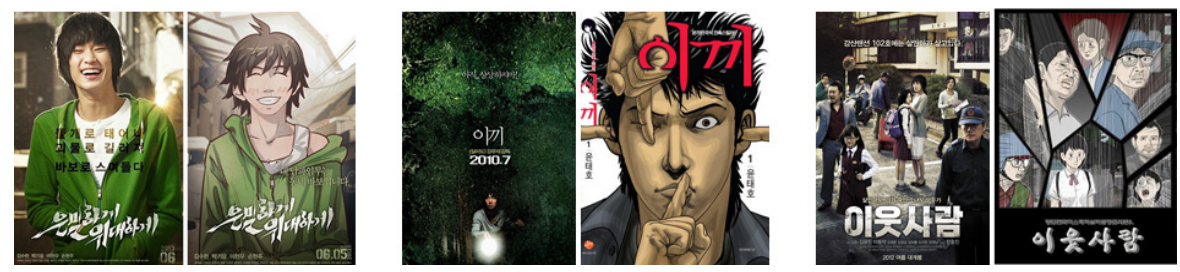

〈마음의 소리〉의 인기는 장르의 확장에서 그치지 않는다. '애봉이미스트', '조석 쿠 션', '부욱 수분크림'과 같은 작품 속 캐릭터와 이미지를 활용한 제품들이 출시되는 등 콘텐츠가 보유한 저작권과 상표권을 활용해 연계 상품의 출시로 이어진다. 이처럼 캐릭 터를 활용하는 등 웹툰 작품의 라이선싱을 활용해 머천다이징 사업을 확장하며 웹툰을 구독하고 있는 독자들은 물론, 구독하고 있지 않은 비독자들까지 캐릭터가 노출되며 수 요자가 확산되는 효과를 나타냈다.

[그림 2-22] 조석의 〈마음의 소리〉라이선싱을 활용해 출시한 제품39)

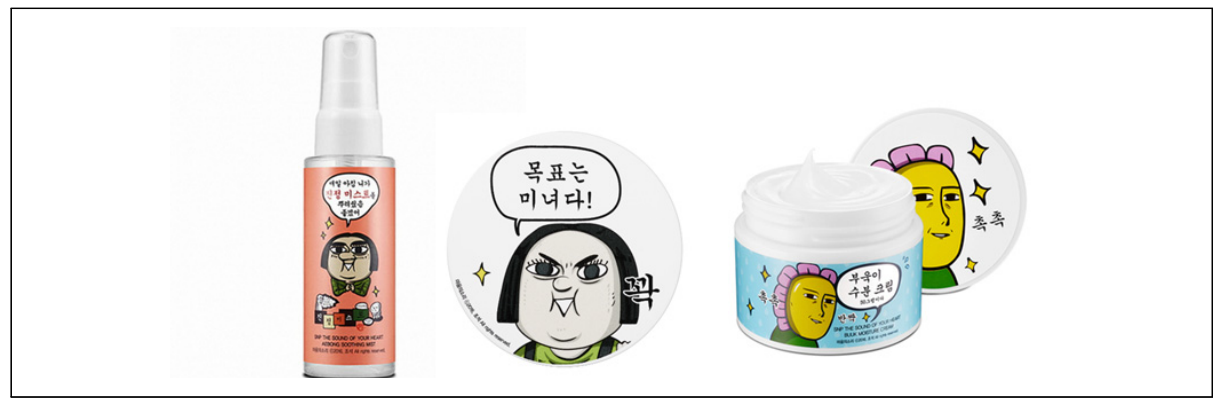

콘텐츠의 장르가 확장되고 머천다이징 사업이 확장되는 등 웹툰의 OSMU화가 활발해 짐에 따라 웹툰 플랫폼들은 그들이 보유하고 있는 다양한 원작 IP를 활용한 플랫폼 맞춤 형 콘텐츠를 확산하기 시작한다. 2018년 전자책과 만화 사업을 중심으로 하던 카카오페

38) 네이버 영화 홈페이지 중 영화 〈은밀하게 위대하게〉, 〈이끼〉, 〈이웃사람〉의 포스터

(https://movie.naver.com/movie/bi/mi/basic.naver?code=92575, https://movie.naver.com/movie/bi/mi/basic.naver? code $=52326$, https://movie.naver.com/movie/bi/mi/basic.naver?code=93090)

한겨레, '스릴러' 로 돌아온 극화 만화의 고수 (2008.02)

ZDNet Korea, '이웃사람' 비하인드 웹툰 공개 -관심집중 (2012.08)

39) 쿠팡, 마음의 소리 애봉이 진정 미스트 (https://www.coupang.com/vp/products/9522097) 
이지는 방송국 및 케이블 체널과 같은 영상 컨텐츠 업체들과 제휴헤 영상 플랫폼을 추가 함으로써 드라마 및 예능 다시보기 서비스를 시작하며 플랫폼에 새로운 변화를 주었다. 웹소설이 원작인 〈김비서가 왜 그럴까〉는 카카오 페이지에서 5천만 이상의 조회수를 기 록한 인기 콘텐츠였다. 이러한 웹소설 IP를 웹툰으로 재생산해 연재하였으며 역시 큰 인기를 끌게 되었고, $\mathrm{tvN}$ 과 협력해 드라마 방송 콘텐츠로써도 성공하게 된다. 이렇듯 웹툰 플랫폼들은 웹툰 콘텐츠뿐만 아니라 다양한 콘텐츠의 기반이 될 수 있는 원천 IP를 개발하는데 집중하게 되고, 그 원천 IP를 기반으로 다양한 플랫폼 별 특성에 맞도록 콘 텐츠를 재생산하며 비즈니스 영역을 확대해 나갔다.

[그림 2-23] 웹소설에서 웹툰, 드라마까지 장르가 확장된 〈김비서가 왜 그럴까〉40)

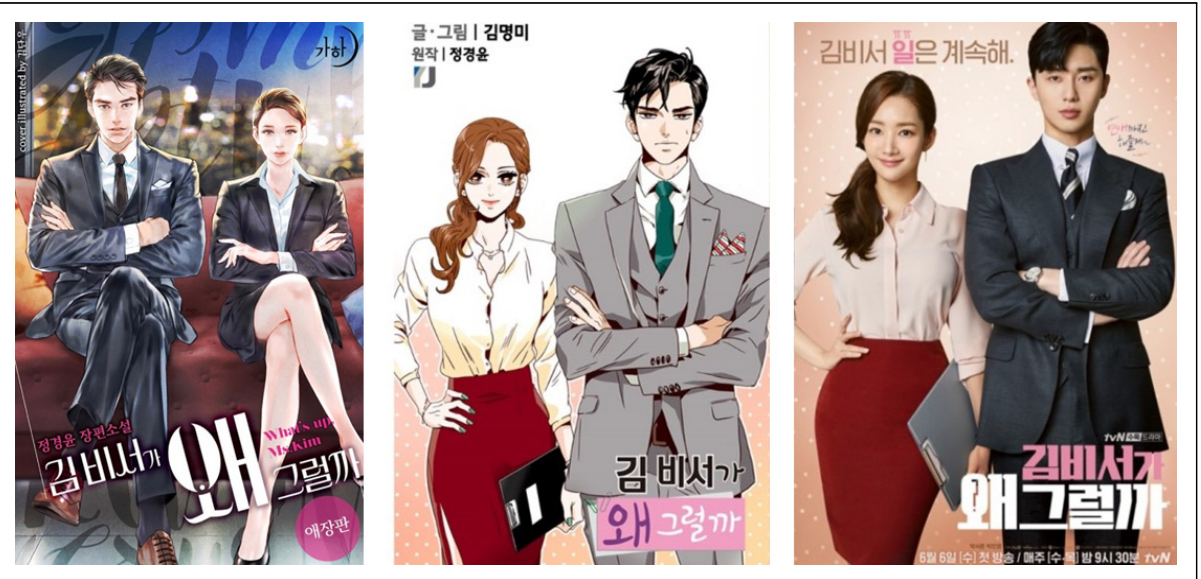

2) IP 세계관의 확장

이전까지만 해도 웹툰 비즈니스 산업에서 웹툰의 OSMU에 대해 논의했다면 지금은 웹툰 IP 확장에 포커스를 맞추고 있다. 웹툰 사업은 소비자들이 흥미로워 할 만한 재미 있는 이야기를 찾아 개발하고 소비자들에게 제공하는 스토리 엔터텐인먼트 사업이기 때 문이다.

대다수가 IP 확장을 OSMU의 범위가 넓어진 것이라고 생각하지만 두 의미는 그 전략 의 시작에서 명확한 차이점을 가지고 있다. OSMU(One Source Multi Use)는 말 그대 로 하나의 소스를 다양한 장르로 확장하는 개념이다. 반면 IP 확장은 기획 단계에서 플

40) 줌뉴스, "한국의 이야기를 수십조원 산업으로 키울 것" (2018.07) 
랫폼의 확장을 고려하고 사업을 전개한다는 것에 있어 기획의 시작이 다르다고 할 수 있다. 즉, OSMU는 하나의 콘텐츠가 성공하면 다양한 장르로 2 차 활용하는 포스트 플래 닝적 비즈니스 전개라면, IP는 이야기의 시작부터 확장 컨텐츠 유형들을 미리 고민하고 초기 단계부터 기획하는 프리 플래닝으로 운영된다. 또한 OSMU는 어떤 이야기를 어떤 사람들에게 할지 캐릭터와 스토리를 고민하는데 중점을 둔다면, IP는 어떤 세계관을 가 지고 어떤 세상과 관련된 이야기를 할지, 기초적인 세계관을 먼저 세팅하고 그 안에서 일어날 캐릭터들과 관련된 서사에 중점을 둔다.41)

이러한 측면에서 콘텐츠 플랫폼 사업자들은 스토리로 유저를 확보하기 위해 IP 세계 관을 확장하는데 중점을 두고 있다. IP 세계관의 확장은 두 가지의 방법으로 구분할 수 있다. 첫 번째는 기존에 있었던 성공한 IP를 기반으로 세계관을 확장하여 새로운 컨텐츠 를 지속적으로 생산하는 것이다. 콘텐츠 제작사 '플레이리스트'는 신규 콘텐츠 〈플렌즈〉 의 배경을 통해 자사에서 제작한 작품들을 하나로 잇는 세계관 '플리버스(Playlist + Universe)'를 공개했다. '플레이리스트'의 기존 작품 〈이런 꽃 같은 엔딩〉의 주인공과 〈연애플레이리스트〉의 주인공을 〈플렌즈〉에 등장시켜 주인공들 간의 인연을 맺게 한다. 이와 동시에 각 드라마의 배경과 캐릭터들을 하나의 지도로 정리해 SNS 등에 공개하며 세계관 구축 작업을 진행하고 있다. 이와 같은 방식은 이미 대중으로부터 작품성과 흥행 성을 인정받은 IP를 기반으로 해 소비자들의 몰입도를 높일 뿐만 아니라 컨텐츠가 성공 할 확률이 높다는 장점이 있다.

두 번째는 마블 스튜디오의 '마블 시네마틱 유니버스(MCU)'처럼 콘텐츠 기획 단계부 터 거대한 세계관을 구축하고 콘텐츠를 공개하는 것이다. 웹툰 제작사 와이랩은 인류의 멸망을 앞두고 각각 다른 차원에서 사는 주인공들이 위기에서 벗어나기 위해 맞서 싸우 는 ‘슈퍼스트링’이라는 세계관을 구축하고 〈부활남〉, 〈테러맨〉, 〈심연의 하늘〉, 〈신암행 어사〉, 〈신석기녀〉 등 16 개의 작품을 선보였다. 이러한 작품들은 공개한 시기가 서로 맞지 않음에도 불구하고 후발 작품의 주인공들이 이미 이전 작품에 등장하는 것으로 보 아 콘텐츠가 공개되기 전부터 스토리가 탄탄하게 계획되어 있다는 것을 알 수 있다. 이 어서 와이랩은 마블의 〈어벤져스〉처럼 각 웹툰의 주인공들을 한 작품에 함께 등장시키 는 IP 확장을 추진하고 있다.42)

41) 경기콘텐츠진흥원, 웹툰 산업의 오늘과 내일 - 2020 경기 웹툰컨퍼런스 中 OSMU와 IP확장의 차이는 무엇인가? (메리크리스마스 유정훈 대표, 2020) 
이처럼 IP 세계관의 확장은 동일한 배경 내에서 다양한 스토리를 창조하고 생산할 수 있다는 점에서 콘텐츠 IP 확장에 효과적이라고 할 수 있다.

[그림 2-24] 웹툰 제작사 와이랩이 구축한 IP 세계관 ‘슈퍼스트링’의 타임라인43)

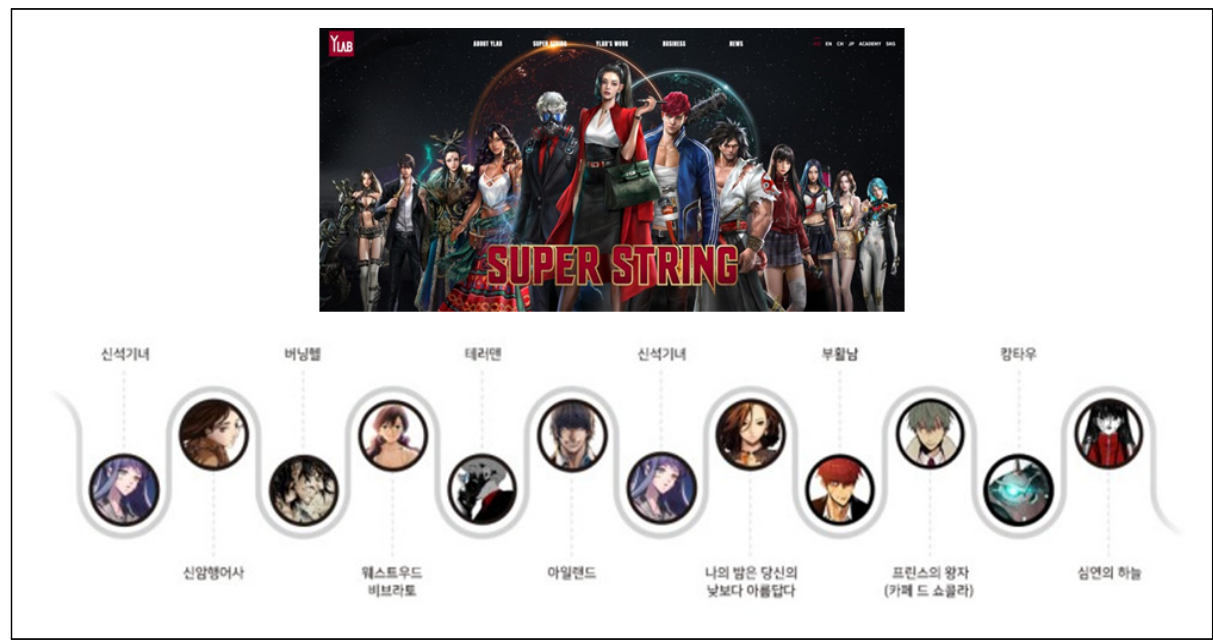

\section{3) 슈퍼 $I P$ 의 발굴}

플랫폼과 플랫폼을 연결시키는 컨텐츠의 조화, 스토리 IP를 기준으로 기존 가입자를 분석하고 새로운 스토리 IP를 통해 신규 가입자를 주기적으로 발굴한다는 등의 이유로 IP 확장의 중요성이 대두되면서 국내 주요 IT 기업을 중심으로 슈퍼 IP의 개념이 정의되 고 있다. 슈퍼 IP란 특정 콘텐츠의 배경에 구애받지 않고 어떤 형태로든 자유롭게 변형 가능한 IP로, 세계관이 탄탄하고 확장성 있는 IP를 의미한다.

다양한 콘텐츠 사업들이 있지만 특히 웹툰과 웹소설 플랫폼을 중심으로 슈퍼 IP를 인 큐베이팅하는 것은 타 콘텐츠의 포맷에 비해 소재나 장르, 제작비와 분량의 제한을 덜 받을 뿐만 아니라 다양한 스토리로 퍼블리싱이 가능하며, 창작자와 기획자 모두 연재 중에 실시간으로 피드백을 받으며 스토리를 개발할 수 있어 IP 확장에 특장점화된 사업 이라고 평가하기 때문이다.44)

42) 동아닷컴, 마블 유니버스처럼... 국내 국내 웹드라마-웹툰에도 '세계관 통합' 바람 (2021.07)

43) 웹툰 슈퍼스트링 홈페이지와 타임라인 (https://comic-superstring.naver.com/universe)

44) 경기콘텐츠진흥원, 웹툰 산업의 오늘과 내일 - 2020 경기 웹툰컨퍼런스 中 플랫폼 시대의 IP 기획과 확장 (카카오페이지 홍민영 부사장, 2020) 
대표적인 콘텐츠 플랫폼 키카오페이지는 원천 스토리 시장에 주목하며 가능성이 높은 웹툰과 웹소설을 중심으로 슈퍼 IP 전략을 강화하고 있다. 단순히 웹툰을 드라마나 영화 로 옮기는 OSMU식의 전개가 아닌 웹툰이 가지고 있는 스토리를 기반으로 세계관을 확 립, 이를 바탕으로 서로 다른 내용의 스토리를 연계하여 다양한 콘텐츠로 선보이는 전략 이다. 카카오 페이지는 이러한 전략을 기반으로 〈이태원 클라쓰〉와 〈스틸레인(강철비)〉, 〈승리호〉 등을 통해 슈퍼 IP 프로젝트를 진행하고 있다.45)

45) IT조선, 세계관으로 웹툰·영화·드라마 묶는 '슈페P' 전략 (2020.11) 


\section{제4절 소결}

이상의 웹툰 산업 현황의 내용을 정리하면서 얻을 수 있는 정책적 시사점은 웹툰산업 의 경쟁력과 한계점과 연결된다. 웹툰산업이 지니고 있는 경쟁력은 극대화할 수 있는 정책방안이 필요한 반면, 현재 웹툰의 한계점은 정책적으로 극복하여 산업의 고도화를 이끌 수 있어야 한다.

\section{1. 웹툰산업의 한계점}

\section{가. 아직 해외시장에서는 진출초기인 도입기}

앞서 살펴본 바와 같이 웹툰산업은 국내에서는 성장기에 다다랐지만 해외 시장에서는 아직 인지도와 도입기에서 성장기 초기 정도에 해당한다. 해외 웹툰산업은 국내 웹툰산 업에 비해 10 년 정도의 시간차이를 두고 있으나 국내 웹툰 기업들이 대거 해외로 진출하 고 있어 국내 기업들의 노하우가 빠르게 해외로 전파될 것으로 기대된다. 우리나라의 웹툰산업이 빠르게 성장할 수 있었던 배경에는 빠른 모바일 인터넷 환경도 한 몫을 했는 데, 해외 모바일 인터넷 환경도 빠르게 구축되고 있고, 향후 속도가 더 빨라질지언정 느 려질 리는 없기 때문에 국내 기업들이 비축한 노하우와 다양한 작품들은 향후 해외에서 웹툰 관련 사업을 영위할 때 유리한 점으로 작용할 가능성이 크다. 콘텐츠산업의 다양한 장르 중에서 웹툰과 같이 유리한 입지를 선점한 분야는 생각보다 많지 않다. 때문에 관 련된 지원 정책을 수립해 나갈 필요성이 제기된다.

\section{나. 부족한 산업적 면모}

웹툰산업의 수요와 공급은 지속적으로 확대될 것인데 비해 산업으로서의 면모를 갖출 
필요성은 있다. 우리나라에서 웹툰이 각광을 받고 있지만 산업으로서의 면모를 제대로 갖추었는지에 대해서는 고찰이 필요하다. 네이버, 카카오 등의 대형 플랫폼 기업 주도로 웹툰산업이 만들어져 온 측면이 있고, 이는 기업의 필요에 따라 만들어진 내용이 대부분 이다. 웹툰산업의 잠재력이 커지면서 다른 중소 규모 플랫폼, 에이전시, 작가 등이 웹툰 산업에 참여하여 다양한 사업들을 벌이고 있으나, 아직까지 이 분야에 대한 제대로 된 통계, 정보는 부족한 편이다. 제대로 된 산업이 되기 위해 부족한 부분이 무엇인지 살피 고 이것을 보완하기 위한 다양한 시각들이 웹툰 산업으로 들어와야 할 것이다.

\section{다. 불법유통 취약}

웹툰산업은 불법유통에 매우 취약하다. 웹툰 불법 유통사이트 '밤토끼' 의 시례에서 보듯 이 유력한 불법 웹툰 유통 사이트 하나만 있더라도 웹툰 산업의 매출에 큰 영향을 준다. 불법 유통 이슈는 국내만의 문제는 아니다. 물론 밤토끼의 시례는 해외에 서버를 둔 국내인 의 불법유통과 이를 이용한 국내인들의 행위가 대부분을 이루었던 시례이지만, 웹툰의 해 외 진출 본격화와 더불어, 이러한 문제를 방치할 경우 그 피해는 상당히 크게 파급될 수 있다. 불법유통 문제는 국내에서의 해당 기업, 작가들의 활동만으로 해결이 어렵다. 그래서 정부가 적극적으로 역할을 해야하고, 해외 정부 및 기관과도 공조체계를 마련해야 한다. 웹툰산업은 특히 우리 기업들이 선도하고 있는 분야이기 때문에 각별한 관심이 요구된다.

\section{2. 웹툰산업의 경쟁력}

\section{가. 새로운 디지털 콘텐츠로의 높은 가능성}

디지털 중심의 콘텐츠 소비 패턴을 고려했을 때 웹툰은 새로운 디지털 콘텐츠나 스낵 컬처로 각광을 받을 가능성이 높다. 웹툰이 오늘날 이렇게 각광을 받게 된 데이는 소비 자의 이용 패턴이 달라진 것에 따른 영향이 크다. 과거에는 일정 장소와 시간에 머물러 서 콘텐츠를 소비해야 했지만, 지금은 모바일로 콘텐츠를 소비하는 것이 매우 일반화되 었고, 그에 따른 짧은 형태의 콘텐츠 소비가 더 적합하다. 이러한 패턴은 콘텐츠의 길이 에도 영향을 주고 있다. 드라마나 영화의 플레이타임은 조금씩 짧아지는 추세이다. 웹툰 
은 언제든 보다가도 멈추고 일상을 이어갈 수 있다. 기존의 인쇄된 만화에 비해 핸드폰 으로 소비하기에도 더 적합하다. 웹툰의 캐릭터를 잘 활용하면 모바일에서 SNS등을 통 한 의사표현이 가능한 이모티콘 등으로 활용될 여지도 충분하다.

\section{나. IP로의 높은 비즈니스 가치}

웹툰은 IP산업으로서 높은 비즈니스 가치를 지닌다. 콘텐츠산업은 태생적으로 높은 리스크를 가지고 있다. 기획만으로 결과물의 좋은 성과를 정확히 예측하기가 어렵고 1 편 의 성공이 2 편의 성공을 보장하지도 않는다. 윕툰은 타 장르 대비 제작에 따른 리스크가 적으면서도 다른 장르의 콘텐츠로 변형시키는데 매우 유리한 형태를 가지고 있다. 웹툰 은 유통을 디지털화하여 플랫폼으로 하기 때문에 작가 원고료를 제외하면 커다란 비용 이 발생하지 않는다. 또한 웹툰의 화면 구성은 드라마나 영화 등 영상물을 제작할 때 그대로 활용될 수 있는 기획 콘티 역할을 해 준다. 이미 국내의 다양한 웹툰 IP들이 영상 으로 제작되어 다양한 성과를 거둔 바 있다. 웹툰이 어느 정도의 인지도를 얻게 되면 이를 기반으로 다른 영상물을 제작하여도 어느 정도의 흥행을 예상할 수 있다. 뿐만 아 니라, 웹툰 캐릭터를 활용한 캐릭터 완구산업에서의 활용도를 생각한다면 원천으로서의 웹툰산업의 가치는 매우 크다.

\section{다. 축적된 비즈니스 노하우}

국내 웹툰산업은 20년이 가까운 역사 속에서 다양한 비즈니스 경험을 습득할 수 있었 다. 초기에 무료를 통해 접근성을 높이다 미리보기 유료, 완결 후 유료, 기다리면 무료 (미리보면 유료)와 같은 다양한 유료화 정책을 통해 큰 거부감 없이 독자들이 유료모델 에 접근할 수 있도록 유도하였다. 이는 국내 뿐 아니라 해외에서도 시간차를 두고 같은 방식으로 적용하고 있기도 하다. 무료로 웹툰 콘텐츠를 접하다 점차 유료로 전환하여 수익성을 높이는 마케팅 노하우를 일본이나 유럽 등 해외에서도 시도하여 유의미한 성 과들이 나타나기 시작하고 있다. 게다가 아직은 절대적 규모가 작은 수준이지만 PPL, 브랜디드 웹툰 콘텐트, 광고 모델 등 이미 다양한 형태로 개발해 놓은 비즈니스 모델을 적용하여 글로벌 무대로 시장파이를 넓힐 수 있다. 
웹툰산업 해외진출 진흥 방안 연구

제3장

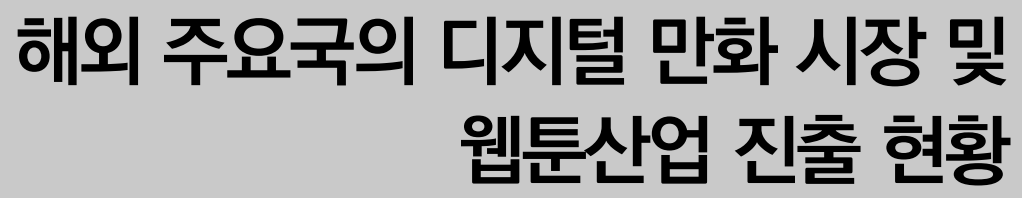





\section{제1절 일본 현황}

\section{1. 일본 디지털 만화 시장 현황}

\section{가. 일본의 디지털 만화 시장 현황 및 동향}

1) 일본 만화 및 디지털 만화 시장 규모

일본의 만화시장 규모는 인쇄 출판 시장이 매년 하락세를 기록하고 있는 반면 디지털 만화부문이 이를 상쇄하며 지속적인 성장세가 나타나고 있다. PWC에 따르면 전 세계에 서 가장 큰 만화 시장인 일본 만화시장의 규모는 2019년 기준 45억 6,900만 달러로 전년 대비 $14.3 \%$ 증가하면서 2017년 하락을 경험한 이래로 꾸준히 성장해 신기록을 기록하였다.

[그림 3-1] 일본 만화산업 규모

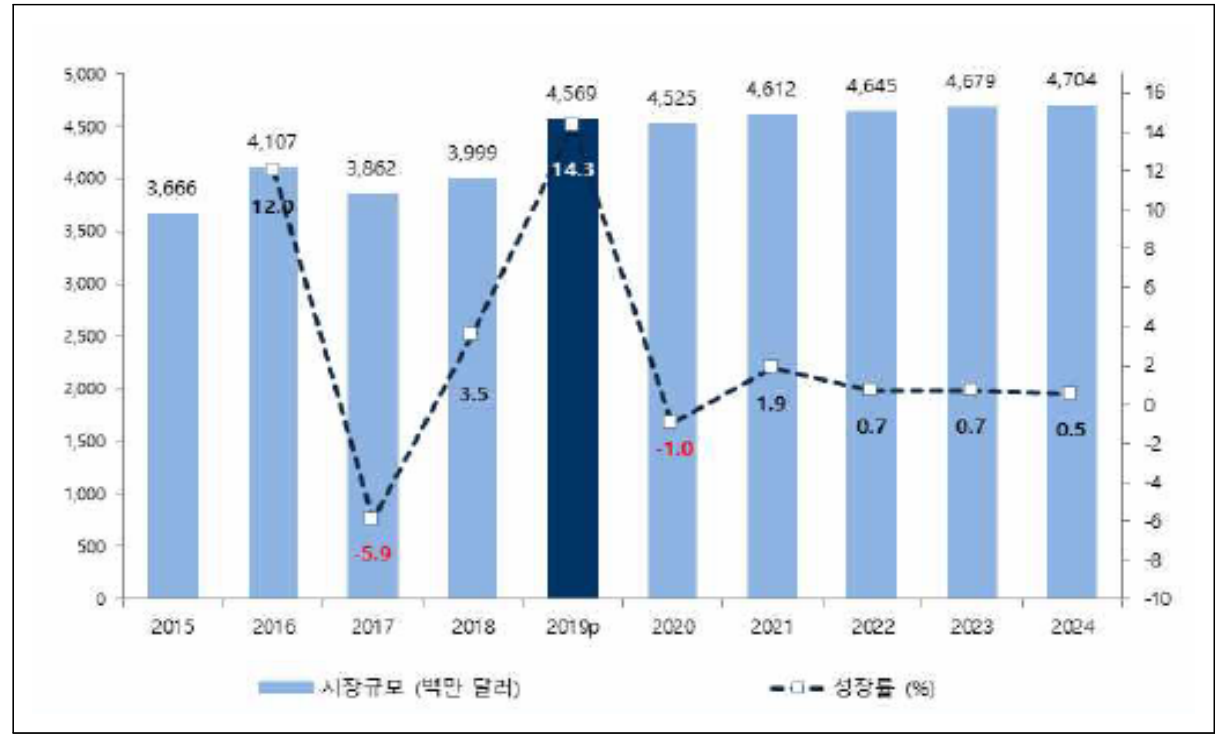

자료: 公縊社団法人全国出版協会, 出版月報, PwC(2020) 
구체적으로 일본만화 시장에서 디지털 만화의 비중은 2015년 26.3\%에 불과했지만, 2019년 들어 처음으로 인쇄만화를 상회하며 52.1\%를 기록하였다. 일본 디지털 만화 규 모는 2015년 9억 6,600만 달러에서 2019년 23억 7,800만 달러 규모로 4년 동안 $246 \%$ 의 급격한 성장을 이루었다. 반면 인쇄만화 같은 경우에는 2015 년 27 억 덜러 규 모에서 지속적으로 감소하여 2019년에는 21억 9,000만 달러를 기록하였다. 이와 같은 디지털 만화의 강세와 인쇄만화의 약세는 향후에도 계속되어 PwC에 따르면 2015년 $26.3 \%$ 였던 디지털 만화의 비율은 2024 년에는 $57 \%$ 이상을 차지할 것으로 예측된다.

[그림 3-2] 일본만화 시장에서 디지털 만화가 차지하는 비중 변화

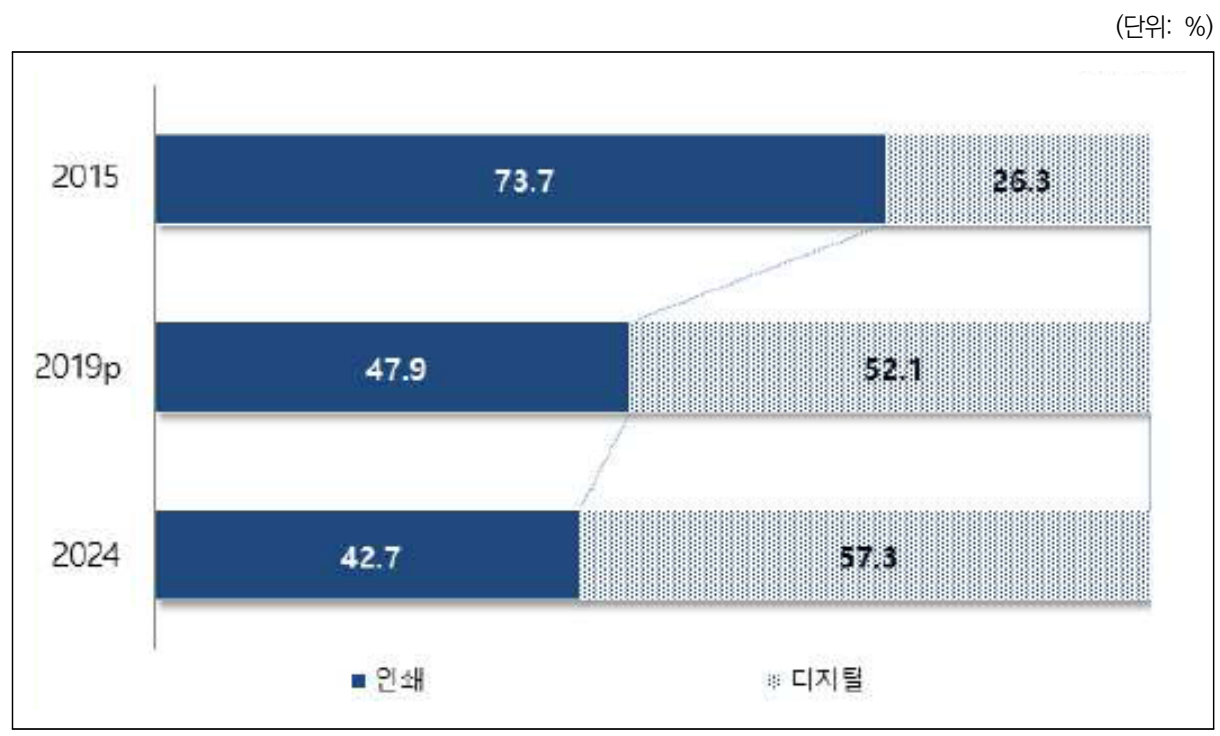

자료: 公益社団法人全国出版協会, 出版月報, PwC(2020)

\section{2) 일본 디지털 만화 경쟁 구조}

일본의 디지털 만화 시장의 주체는 인터넷·IT 기업, 만화 출판사, 게임사로 분류된다. 이들 중 가장 먼저 디지털 만화 시장에 뛰어든 주체는 인터넷·IT 기업들이다. 이들 중 카카오의 〈픽코마(ピッコマ)〉, 네이버 계열인 라인의〈라인망가(LINE マンガ)〉, NHN의 〈코미코(Comico)〉 등 한국에서 넘어온 웹툰 업체들은 일찍부터 일본 시장에 진출하여 선점효과를 거두었다. 이들은 한국의 웹툰 콘텐츠 뿐 아니라 현지의 일본 콘텐츠들을 다수 유통하면서 현지 시장의 독자층을 유입하였다. 또한 에피소드별로 구매하는 방식의 
비즈니스 모델을 소개하여 좋은 반응을 얻으면서 기존의 1권씩 구매하는 방식을 변화시 키는 영향을 미쳤다. 한편 일본의 인터넷·IT인 아마지아가 운영하고 있는 〈망가BANG!〉 또한 일본의 유명 출판사와 계약을 맺고 다양한 장르의 만화작품을 디지털 방식으로 제 공하고 있다.

인터넷·IT 기업들의 디지털 만화에서의 성장을 지켜본 일본 대형만화 출판사들도 디 지털 만화시장으로의 빠른 독자 유입에 위기의식을 느끼며 디지털 만화 서비스를 다양 하게 제공하기 시작하였다. 이들은 이미 자사가 보유하고 출판만화들의 높은 인지도 작 품들과 충성도 높은 독자층을 기반으로 공격적으로 디지털 유통을 시도하고 있다. 슈에 이샤, 코단샤, 쇼가쿠칸 등 대표적인 대형만화 출판사들이 다양한 디지털만화 서비스를 개발하여 제공 중이다. 사실 이들은 망가무라(漫画村)와 같은 불법 만화유통 사이트들의 성행으로 큰 피해를 입어왔기 때문에 디지털 만화 유통을 막아야만 하는 대상으로 여기 는 경향이 있었다. 하지만 디지털 만화가 스마트 기기의 앱 시장으로 진출하여 거부감 없이 독자들에게 이용되는 것을 목격하면서 침체되고 있는 출판만화 시장의 새로운 대 안으로 판단하게 되었다. 대부분의 출판사들이 제공하는 디지털 만화 서비스들은 스캔 중심의 출판 만화와 동일한 가로 읽기 방식을 도입하여 제작이나 유통에서 디지털화가 완전히 이루어지지는 못하고 있다. 다만, 웹툰의 유료 비즈니스 모델이 시장에서 안착하 게 되자 '기다리면 무료'와 같은 부분 유료화 정책을 도입하고 있다.

마지막으로 게임사들은 자사가 소유하고 있는 게임 캐릭터 등의 IP를 적극 활용하여 이들을 원천으로 만화 콘텐츠를 만들고 디지털 만화 서비스를 통해 제공하는 형식을 취 하고 있다. 스퀘어 에닉스는 〈망가UP!〉이라는 서비스를 통해 100 개 이상의 자사 인기 $\mathrm{IP}$ 를 활용한 콘텐츠들을 제공 중이며 사이게임즈도 〈사이코미〉를 통해 게임 팬덤을 활 용하여 독자들을 유입하고 있다. 
〈표 3-1〉 일본의 디지털 만화 사업자 현황

\begin{tabular}{|c|c|c|c|c|}
\hline 구분 & 기업 & 서비스명 & 주요 콘텐츠 & 수익화 전략 \\
\hline \multirow{4}{*}{$\begin{array}{l}\text { 인터넷 } \\
\text { /IT } \\
\text { 기업 }\end{array}$} & 라인 & $\begin{array}{c}\text { 라인망가 } \\
\text { (LINEマンガ) }\end{array}$ & $\begin{array}{l}\text { - 로맨스/소년/청년 만화 중심으로 오리지널 만화 및 } \\
\text { 선독점 작품 제공 } \\
\text { - 드라마화 또는 애니메이션화된 다양한 작품 } \\
\text { - 일본 인기 만화 잡지 만화도 라이선스 계약을 통해 } \\
\text { 제공 }\end{array}$ & $\begin{array}{l}\text { - '기다리면 무료', 작품 제한 없이 23시간마다 1화 } \\
\text { 대여권 충전 } \\
\text { - 친구에게 추천하거나 광고를 보면 충전 시간 단축 } \\
\text { 가능 }\end{array}$ \\
\hline & $\mathrm{NHN}$ & $\begin{array}{c}\text { 코미코 } \\
\text { (Comico) }\end{array}$ & $\begin{array}{l}\text { - 여성향 중심이나 개그, 호러, 액션 만화 및 소설 등 } \\
\text { 다양한 장르 작품도 제공 } \\
\text { - 오리지널 작품 및 매체화된 인기 작품 다수 보유 }\end{array}$ & $\begin{array}{l}\text { - 대부분의 콘텐츠 무료 제공, 유료 분량도 } 10 \text { 회까지 } \\
\text { 무료 제공 } \\
\text { - 최초 다운로드 시 포인트 지급 } \\
\text { - 광고 시청 시 추가 대여권 제공 }\end{array}$ \\
\hline & $\begin{array}{l}\text { 카카오 } \\
\text { 재팬 }\end{array}$ & $\begin{array}{c}\text { 픽코마 } \\
\text { (ピッコマ) }\end{array}$ & $\begin{array}{l}\text { - 연애, 판타지, 개그 만화, 라이트노벨 등 다양한 장 } \\
\text { 르 만화 제공, } 300 \text { 개 이상의 선독점 작품 제공 } \\
\text { - 이용자 취향에 따른 작품 추천 기능 제공 }\end{array}$ & $\begin{array}{l}\text { - '기다리면 무료', 작품 제한 없이 매일 } 1 \text { 화 대여권 } \\
\text { 충전 } \\
\text { - 연재 만화 업데이트 당일 결제 시 보너스 코인 지 } \\
\text { 급 등 각종 이벤트 통해 코인 지급 }\end{array}$ \\
\hline & 아마지아 & $\begin{array}{c}\text { 망가BANG! } \\
\text { (マンガBANG!) }\end{array}$ & $\begin{array}{l}\text { - 일본 유명 출판사의 인기 만화 및 다양한 장르의 오 } \\
\text { 리지널 만화 작품 제공 }\end{array}$ & $\begin{array}{l}-1 \text { - } \text { 일 8회분 무료 대여권 제공 } \\
\text { - 광고 시청을 통해 } 1 \text { 일 } 5 \text { 회까지 유료 연재분 무료 } \\
\quad \text { 열람 가능 } \\
\text { - 매주 1권씩 인기 작품 기간 한정 무료 열람권 제공 }\end{array}$ \\
\hline \multirow{10}{*}{$\begin{array}{l}\text { 만화 } \\
\text { 출판사 }\end{array}$} & \multirow{6}{*}{ 슈에이샤 } & $\begin{array}{c}\text { 소년점프+ } \\
\text { (少年ジャンプ+) }\end{array}$ & $\begin{array}{l}\text { - 출판 만화잡지 《주간 소년 점프》연재작 } \\
\text { - 소년점프 발매일 당일 출판 잡지보다 저렴한 가격으 } \\
\quad \text { 로 다운로드 가능 }\end{array}$ & $\begin{array}{l}\text { - 유명 작품 첫 3회 무료 열람 가능 } \\
\text { - 게임 참여 또는 추천 앱 다운로드시 보너스 코인 } \\
\quad \text { 지급 } \\
\text { - 특정 인기 만화 기간 한정 무료 열람 등 프로모션 } \\
\quad \text { 제공 }\end{array}$ \\
\hline & & $\begin{array}{l}\text { 망가Mee } \\
\text { (マンガMee) }\end{array}$ & $\begin{array}{l}\text { - 주로 순정만화를 취급 } \\
\text { - 오리지널 작품 보유 } \\
\text { - 매체화된 인기 작품, 최신 연재 작품 및 완결 명작 } \\
\quad \text { 만화 보유 }\end{array}$ & $\begin{array}{l}\text { - '기다리면 무료', 작품 제한 없이 23시간마다 1화 } \\
\text { 무료 } \\
\text { - 잡지 정기 구독 시 첫 달 무료 } \\
\text { - 첫 다운로드 시 500포인트 지급 }\end{array}$ \\
\hline & & $\begin{array}{l}\text { 점프 Book 스토어 } \\
\text { (ジャンプBOOK) }\end{array}$ & $\begin{array}{l}\text { - 《주간 소년 점프》, 《주간 영 점프》 등 인기 출판 잡 } \\
\text { 지 만화 연재작 }\end{array}$ & $\begin{array}{l}\text { - 유료 다운로드 방식, 종이책보다 저렴한 가격으로 } \\
\text { 콘텐츠 제공 }\end{array}$ \\
\hline & & $\begin{array}{c}\text { 제브락 } \\
\text { (ゼブラッ) }\end{array}$ & $\begin{array}{l}\text { - 로맨스, 소년/청소년 만화, 라이트 노벨 등 다양한 } \\
\text { 장르의 작품 제공 }\end{array}$ & $\begin{array}{l}\text { - '기다리면 무료', 작품 제한 없이 23시간마다 1화 } \\
\text { 무료 } \\
\text { - 잡지 만화 정기 구독 서비스 제공 }\end{array}$ \\
\hline & & $\begin{array}{c}\text { 영점프! } \\
\text { (ヤンジャン!) }\end{array}$ & $\begin{array}{l}\text { - 《주간 영점프》 등 인기 청년 만화 잡지의 연재작 중 } \\
\text { 심 } \\
\text { - 소년, 액션, 코미디, 호러 만화 등 다양한 장르 만화 } \\
\text { 제공 }\end{array}$ & $\begin{array}{l}\text { - 《기다리면 무료》, 작품 제한 없이23시간마다 1화 } \\
\text { 무료 } \\
\text { - 주간 영점프 최신호 다운로드 시 매주 작품 1편 무 } \\
\text { 료 열람 가능 } \\
\text { - 광고 시청, 이벤트 완수 시 보너스 골드 지급 }\end{array}$ \\
\hline & & $\begin{array}{l}\text { 코믹리보마가 } \\
\text { (コミック } \\
\text { りぼマガ) } \\
\end{array}$ & $\begin{array}{l}\text { - 주로 연애, 순정 만화를 취급하고 있으며, 오리지널 } \\
\text { 작품 중심 }\end{array}$ & $\begin{array}{l}\text { - 부분 유료, 전 작품 1화 열람 가능 } \\
\text { - 특정 작품 전권 무료 열람 가능 }\end{array}$ \\
\hline & \multirow[t]{2}{*}{ 코단샤 } & $\begin{array}{l}\text { 마가포케 } \\
\text { (マガポケ) }\end{array}$ & $\begin{array}{l}\text { - 《주간 소년 매거진》등 인기 출판 잡지 만화 및 오리 } \\
\text { 지널 작품 제공 }\end{array}$ & $\begin{array}{l}\text { - 매일 유료 연재 분량의 1화를 열람할 수 있는 열람 } \\
\text { 권 제공 } \\
\text { - 이벤트 통해 일정 시간 무료로 작품을 볼 수 있는 } \\
\quad \text { 열람권 증정 } \\
\text { - 《주간소년 매거진》 정기 구독 서비스 제공 }\end{array}$ \\
\hline & & $\begin{array}{l}\text { 파루시 } \\
\text { (パルシィ) }\end{array}$ & $\begin{array}{l}\text { - 연애, 일상 만화 등 여성향 만화 취급 } \\
\text { - 기존 코단샤 인기 출판 잡지 만화 및 오리지널 작품 } \\
\text { 제공 }\end{array}$ & $\begin{array}{l}\text { - 최초 다운로드 시 30회분 보너스 티켓 지급, 앱 로 } \\
\text { 그인 횟수 및 작품 열람 횟수 등의 활동 내역에 따 } \\
\text { 른 보상에에일) 지급과 같은 프로모션 제공 }\end{array}$ \\
\hline & \multirow[t]{2}{*}{ 쇼가쿠칸 } & $\begin{array}{c}\text { 망가원 } \\
\text { (マンガワン) }\end{array}$ & $\begin{array}{l}\text { - 쇼가쿠Zks 잡지 만화 및 웹 만화 } \\
\text { 플랫폼 '우라선데이(裏サンデー)' } \\
\text { 연재 작품 } \\
\text { - 여성향, 남성향, 성인 등 세분화된 } \\
\text { 키테고리 및 다양한 장르의 작품 보유 }\end{array}$ & $\begin{array}{l}\text { - 1일 8회의 무료 열람권 증정 } \\
\text { - 최초 다운로드 시 이회의 무료 열람권 증정 } \\
\text { - 잡지 연재 인기 작품을 일정 기간 전권 무료 열람 } \\
\text { 가능한 '한번에 읽기(イッキ読み)' 서비스 제공 } \\
\text { - 광고 시청 시 만화 열람에 필요한 ‘SP 라이프’ 지 } \\
\text { 급 }\end{array}$ \\
\hline & & 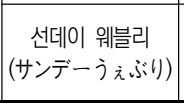 & $\begin{array}{l}\text { - 《주간 소년 선데이》 등 쇼가쿠간의 잡지 연재 만화 } \\
\text { 제공 } \\
\text { - 인기 연재 만화 및 절판된 만화 다운로드 소장 가능 }\end{array}$ & $\begin{array}{l}\text { '- 최초 다운로드 시 } 1000 \text { 포인트 지급, 정기 구독 시 } \\
\text { 매월 } 3 \text { 일 추가 포인트 지급 등 프로모션 제공 } \\
\text { - 동영상 시청 및 프로필 등록 시 포인트 지급 }\end{array}$ \\
\hline
\end{tabular}




\begin{tabular}{|c|c|c|c|c|}
\hline 구분 & 기업 & 서비스명 & 주요 콘텐츠 & 수익화 전략 \\
\hline \multirow[t]{2}{*}{$\begin{array}{l}\text { 게 } \\
\text { 임 } \\
\text { 사 }\end{array}$} & $\begin{array}{l}\text { 스퀘어 } \\
\text { 에닉스 }\end{array}$ & $\begin{array}{c}\text { 망가UP! } \\
\text { (マンガUP!) }\end{array}$ & $\begin{array}{l}\text { - } 100 \text { 개 아상의 스퀘어 에늑스 인기 작품 및 오리지 } \\
\text { 널 작품 제공 } \\
\text { - 배틀 만화나ㄱㅗㅗㅍㅗ 만화 등 다양한 장르의 만화 확보 } \\
\text { - 이용자 취항베 따은 인기 만화 추천 기능 제공 }\end{array}$ & 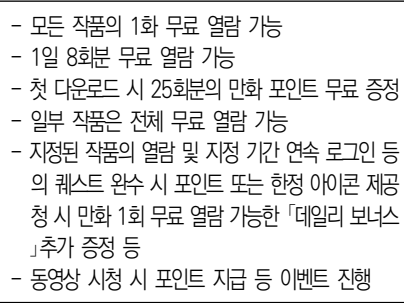 \\
\hline & $\begin{array}{l}\text { 사이 } \\
\text { 게임즈 }\end{array}$ & $\begin{array}{c}\text { 사이코미 } \\
\text { (Cygames) }\end{array}$ & $\begin{array}{l}\text { - 소년 만회를 중심으로 연애, 개그, 일상, 모험, 호러, } \\
\text { 라이트노벨 등 다양한 장르의 작뭄 제공 } \\
\text { - 사이게임즈 IP 활용 오리지널 만화, 오디오 콘텐츠 } \\
\text { 등 제공 }\end{array}$ & $\begin{array}{l}\text { - ‘기다리면 무료', 작품 제한 없이 22시간마다 1화 } \\
\text { 무료 } \\
\text { - 이벤트 참여 시 보너스 코인 지급 등 프로모션 제 } \\
\text { 공 }\end{array}$ \\
\hline
\end{tabular}

자료: 2020 만화산업백서

\section{나. 일본 디지털 만화 주요 동향}

\section{1) 코로나 19로 인해 높아진 만화 수요, 반면 줄어든 공급}

일본에서는 사회적 거리 두기 여파로 '집콕 시간(おうち時間)' 등 비대면 문화가 확산 됨에 따라 만화의 디지털화가 가속화될 것이며 제작 환경 역시 획기적으로 바뀔 것으로 예상된다. 일본에서는 코로나 19 의 여파가 장기화되고 또 다시 감염자가 급증하면서 외 출 자제가 요구되는 가운데 실내에서 가볍게 즐길 수 있는 만화를 읽는 사람들이 증가하 고 있다. 일본 전국출판협회 출판과학연구소(公益社団法人 全国出版協会 · 出版科学研究 所)의 조사에따르면, 2020년 3월 도서 및 잡지 매출은 전년 동월 대비 5.6\% 감소했지 만, 만화는 약 $19 \%$ 증가하였다.

코로나 19 가 만화의 수요를 증가시킨 반면 만화 작가들의 작업을 어렵게 만들어 제작 지연이나 휴재 등 공급 역시 감소시키는 현상이 나타나고 있다. 슈에이샤(集英社)가 발행 하는 주간 만화 잡지 〈주간 소년 점프(週刊少年ジャンプ)〉는 2020 년 4 월 편집부원의 코로나 19 감염이 의심되자 작업을 중단하고 판매를 연기하였다. 쇼가쿠칸(小学館)이 발 행하는 남성용 만화 잡지〈빅코믹(ビッグコミック)〉에서도 일본 만화계의 거장 사이토 타카오(斎藤隆夫)의 신작 발표가 연기되고, 아다치 미츠루(あだち充)의〈MIX〉가 휴재되 었다. 이처럼 일본 내 많은 만화 제작 현장은 여전히 수작업 중심, 즉 '아날로그' 방식으 로 이루어지고 있어 좁은 공간에서 만화가와 여러 명의 어시스턴트가 함께 일하는 환경 에 놓여있다. 베테랑 작가의 휴재가 눈에 띄는 것은 사회적 거리를 확보하기 어렵고, 감 염 위험이 큰 작업 환경과 연관이 있는 것으로 보인다. 
이러한 상황은 만화의 공급이 꾸준하고 다양한 콘텐츠를 축적하고 있는 디지털 만화 플랫폼으로의 유입이 발생하는 기회로 작용하기도 한다. 이용자들이 집에서 보내는 시간 이 증가해 만화에 대한 수요는 증가했는데 기존 만화가 휴재하게 되자 다수의 만화 이용 자들은 디지털 만화를 새롭게 시도하게 되어 온라인 소비로 유입되는 결과로 이어지고 있다.

\section{2) 대표적 불법 만화 유통 사이트의 폐쇄와 정식 유통 서비스로의 이동}

일본에서도 불법복제는 커다란 문제이다. 2016년에 등장하여 일본의 출판사 만화 들 을 온라인 상에서 불법 복제 및 유통을 했었던 〈망가무라〉는 웹툰 불법 유통 사이트들과 마찬가지로 서버를 해외에 두고 광고수익을 챙기는 방식으로 수익을 취했다. 특히 콘텐 츠가 무료인데다 로그인 절차가 필요 없이 만화뿐 아니라 잡지, 소설 등을 편하게 이용 할 수 있어 입소문을 통해 이용자가 급격히 증가하였다. 2018년 기준으로 월간 이용뷰 수 가 9,000만 명이 넘고 일본 전체 웹사이트 접근 순위에서도 30 위권 내에 들 정도로 그 영향도가 매우 높았다. 인쇄만화에만 익숙했던 일본 만화 이용자들은 그 과정에서 온라인상으로 만화를 소비하게 되며 온라인 이용에 익숙해지는 결과도 나타났다.

망가무라가 폐쇄되자 온라인에 익숙해진 만화 이용자들은 다른 대체제를 찾게 되었는 데 이 시기에 많은 관련 사업자들이 디지털 만화 서비스의 정식 연재를 진행하여 큰 효 과를 거두게 되었는데, 디지털 만화를 정식으로 서비스하는 기업이 증가하고, TV 광고 등 적극적인 마케팅을 전개하였다.

\section{3) 만화의 스낵 컬처화와 디지털 전환}

일본에서는 전통적으로 만화 작가에 대한 장인정신과 존경심이 높은 반면 스낵 컬처 에 대해 거부감이 있었다. 때문에 초기 일본에 한국 웹툰이 진출했을 때 웹툰의 빠른 호흡 주기와 일상 장르 중심의 가벼운 소재에 대해 거부감이 있어 일본에서 성공하기 어렵다는 평가가 지배적이었다. 하지만 MZ세대를 중심으로 모바일이 콘텐츠 소비의 주 된 통로가 되고 짧은 길이의 가벼운 소재를 선호하면서 전혀 다른 이용행태로 변화되기 시작하였다. 젊은 층을 중심으로 단행본 1 권을 열독하는 것보다 출퇴근이나 이동 중에 가볍게 만화를 소비하는 경향성이 확대되었다. 앱을 통한 만화소비는 기존 출판 만화의 
소비 비중이 적었던 10 대에서 30대의 여성층을 새롭게 유입시켰다. 여기에 기존의 인쇄 만화도 점차 디지털 만화로 소비하는 방식이 더 많아 지면서 작가 데뷔도 온라인 유통 플랫폼을 통해서 이뤄지는 경우가 발생하고 있다.

인쇄만화보다 디지털 만화의 소비가 향후에도 더 증가할 것으로 예상되기 때문에 웹 툰은 향후 더 큰 기회를 얻을 것으로 기대된다. 여기에 짧은 주기에 제작할 수 있는 노하 우가 생기고 스튜디오 시스템과 같은 기반이 마련됨에 따라 웹툰 콘텐츠의 질적 수준이 향상되어 짧은 호흡에도 깊이 있는 내용의 웹툰이 제작되어 큰 호응을 얻고 있다.

\section{2. 웹툰산업의 일본 진출 현황}

\section{가. 웹툰산업의 일본 디지털 만화 앱시장 주도}

일본 현지법인 카카오재팬을 통해 2016년 4월부터 시작한 웹툰 플랫폼 '픽코마'는 가장 매출이 높고 인기있는 앱으로 자리매김하고 있다. 매일경제(2021)에 따르면 픽코 마는 2020년 한 해 동안 4,100 억 원의 거래액을 기록하며 전년 대비 $188 \%$ 급성장을 하였다. 또한 시장조사업체 앱애니에 따르면, 2020년 7월 기준으로 일본의 애플 앱스토 어와 구글 플레이스토어 모두에서 비게임 부문 전체 앱 수익순위 1 위를 차지하기도 하였 다. 픽코마는 130 여개 일본 출판사와 협력하며 다수의 일본 콘텐츠들을 서비스하고 있 등록된 콘텐츠만 무려 2만여 작품이 넘는다. 주목할 점은 이 2 만여 콘텐츠 중에서 한국 의 작품수는 전체 작품 수에서 $2 \%$ 미만을 차지하고 있지만 전체 매출 비중에서는 절반 이상을 차지하고 있다. 즉, 픽코마의 매출 절반가량은 웹툰에서 발생하며, 나머지는 일 본의 단행본 만화를 스캔한 디지털 코믹스에서 발생하고 있다. 게다가 국내 시장에서의 성공적을 기반으로 일본에 그대로 서비스한 '기다리면 무료'라는 부분 유료화 모델은 현 지에서 좋은 반응을 일으키며 수익성 확장에 큰 기여를 했다.

2013년부터 일본진출을 시작한 '라인 망가'는 이미 일본에서 지배적인 메신저 서비스 인 '라인'이라는 인프라를 적극 활용하여 독자들을 유입시켰다. 시장조사업체 앱애니에 따르면 2021년 3월 기준 일본의 구글 플레이스토어와 애플 앱스토어에서 비(非)게임 부 문 앱 매출 순위에서 픽코마에 이어 2위를 차지하였고 2020년 8월에는 라인망가 앱의 누적 다운로드 수가 3천만 건을 달성하였다. 2018년 5월에는 웹툰사업을 전담하는 자 
회사 '라인 디지털프론티어'를 출범시켜 일본 내 웹툰 사업을 확장하였는데 라인망가의 2018년 기준 매출액은 218억엔(약 2,377억원)으로 2천억 원을 상회한다.

[그림 3-3] 일본 비게임 부문 앱 매출 순위(1위 픽코마, 2위 라인망가)

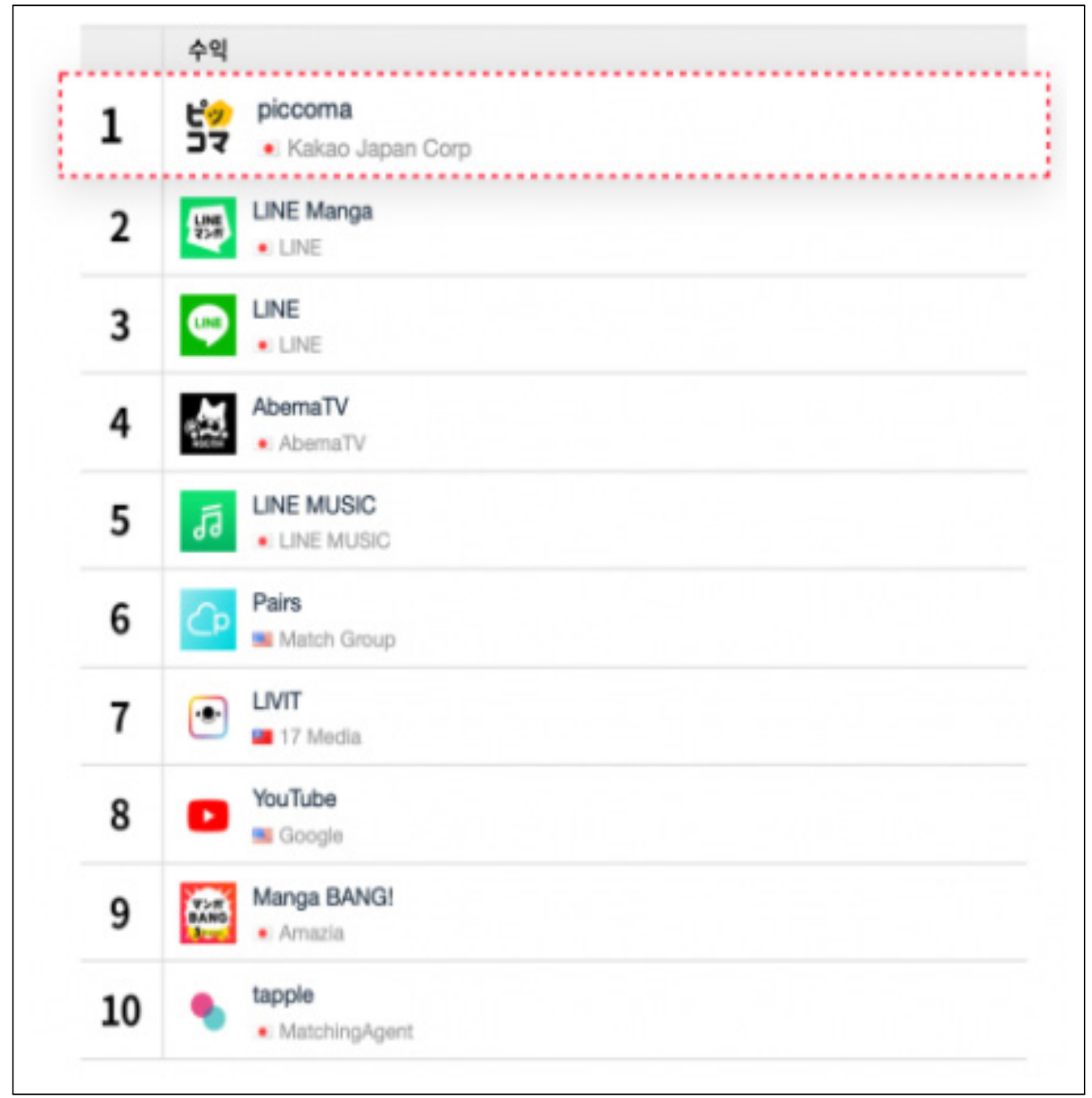

자료: 앱애니(mww.appannie.com)

코미코는 2014년에 일본에 진출하여 만 3년 만인 2017년에 일본 내 만화 앱 순위 1 위를 달성하였다. 코미코는 $\mathrm{NHN}$ 의 일본 자회사인 $\mathrm{NHN}$ PlayArt에서 운영하고 있는 웹툰 유통 서비스로, 한국뿐 아니라 일본의 작가들의 창작 웹툰도 적극적으로 게재하면 서 일본시장 내 입지를 확대하고 있다. 그 외에 레진코믹스는 2015년 4월에, 탑툰은 2015년 5월 일본 시장에 진출하여 국내에서 이미 성공한 콘텐츠들을 중심으로 서비스 를 진행하고 있다. 


\section{나. 메가 히트 만화콘텐츠 창출}

디엔씨미디어에서 기획·제작하여 현재 픽코마, 타파스 등 카카오 플랫폼들에서 연재되 고 있는 〈나 혼자만 레벨업〉은 일본에서만 100 억 원 이상의 수익을 창출하고 전체 300 억 이상의 수익을 거두었다. 〈나 혼자만 레벨업〉은 일본, 중국, 미국, 유럽 등 각국 만화 플랫폼에서 1 위를 차지하고 있으며 일본 카카오재팬 만화 플랫폼인 픽코마에서는 하루 최대 100만 명이 열람하였다. 또한 미국 코믹스 사이트 온망가에서도 일본 유명 만화 ‘원피스'를 제치고 월간 조회수 1 위를 차지하였다. 웹툰을 묶은 단행본 역시도 일본, 브 라질, 독일 등에서 높은 인기를 얻고 있는데, 일본에서 1 4권 누적 판매 부수가 20만 부 이상을 기록했고, 브라질과 독일에서는 1 권 출시 첫 주에 아마존 만화책 부문에서 판매 1 위를 달성 46$)$ 하였다.

46) 한국경제(2020.05.19.), 카카오페이지 ㅂ거래액 20억 돌파 신기록-‘템빨’ 등 100억(매출) 웹툰 속속 $\cdots$ 이 젠 해외로 


\section{제2절 미국 현황}

\section{1. 미국 디지털 만화 시장 현황}

\section{가. 미국의 디지털 만화 시장 현황 및 동향}

1) 미국 만화 및 디지털 만화 시장 규모

PWC에 따르면, 전 세계 2위 시장인 미국 만화 시장은 2019년 기준으로 11억 6,000 만 달러를 기록하며 2017년 이후로 지속적으로 성장세를 이어왔다. 특히 히어로물 중심 으로 영화한 작품들이 전 세계적으로 크게 인기를 끌게 되면서 젊은층의 독자들의 유입 이 두드러지게 나타났다.

[그림 3-4] 미국 만화산업 규모

(단위: 백만달러, \%)

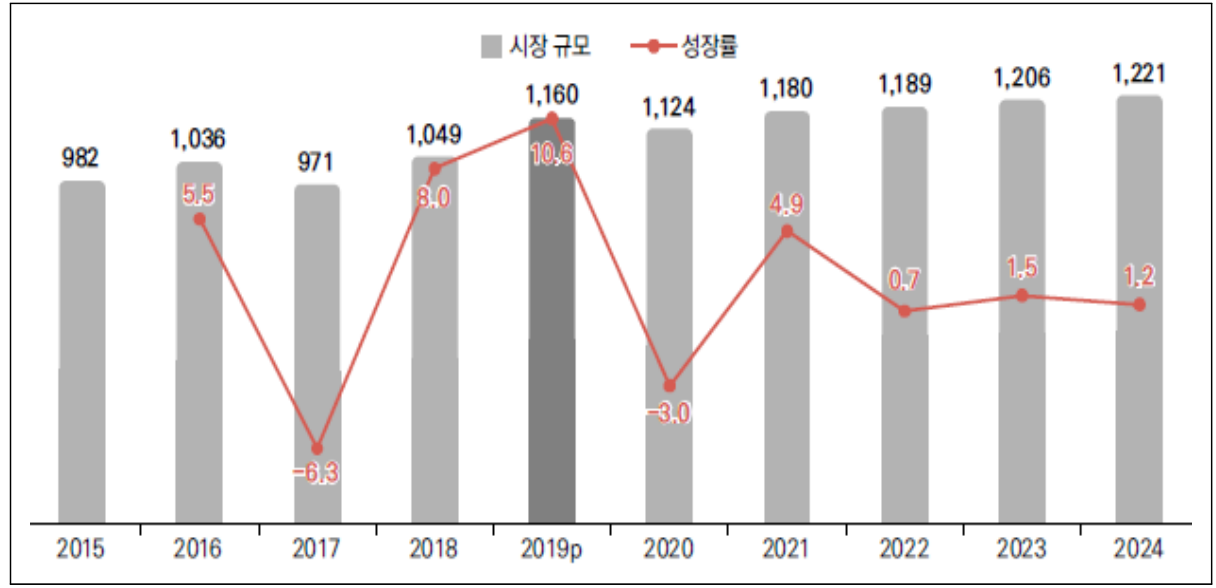

자료: ICV2(2020), SNE(2020), PwC(2020)

미국 시장의 가장 큰 특징은 아직도 절대적으로 인쇄만화의 비중이 절대적으로 높고 디지털 만화의 비중은 매우 조금씩 늘고 있다는 점이다. 미국의 디지털 만화 비중은 
8.8\%를 차지하던 2015년 때보다도 오히려 줄어 2019년 기준 7.4\%를 차지하고 있다. 이는 2010년대 중반에 공격적으로 미국에서 서비스를 진행했던 디지털 만화 플랫폼들 이 생각보다 시장에서 고전했기 때문으로 분석된다.

[그림 3-5] 미국만화 시장에서 디지털 만화가 차지하는 비중 변화

(단위: \%)

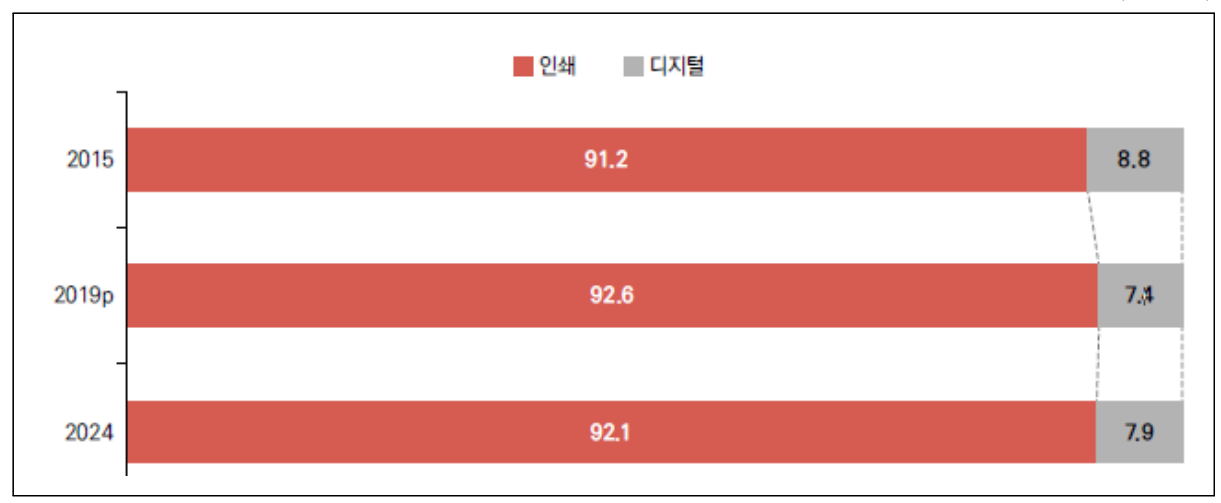

자료: ICv2, Comichron

\section{2) 미국 디지털 만화 경쟁 구조}

2000년대 들어서 그래픽 노블의 대표적인 출판사인 마블 코믹스와 DC 코믹스의 히 어로물들이 영화화를 통해 전세계적 인기를 누리면서 만화가 대중화 되었고, 이후 미국 만화 시장의 성장을 주도하고 있다. 특히 마블의 히어로물들을 영화로 옮긴 세계관인 $\mathrm{MCU}($ Marvel Cinematic Universe)가 엄청난 성공을 거두면서 기존에 장년층을 중심 으로 향유되던 만화가 젊은 층으로 확산되는 큰 계기를 만들었다.

미국 만화는 크게 세 가지로 구분 된다. 먼저 그래픽 노블은 양장본의 형식으로 고품 질의 컬러로 인쇄되는 형식이며, 페이퍼백은 이슈별로 얇은 소책자로 유통되는 형식의 만화이다. 마지막으로 디지털 코믹은 온라인으로 유통되는 디지털 만화를 의미한다. 만 화 원작 히어로물 영상의 흥행과 인기는 자연스럽게 원천 콘텐츠인 마블 코믹스와 DC 코믹스의 만화로 자본이 몰리게 하였고 이에 따라 페이퍼백 형식의 이용은 줄어들고 고 품질의 양장본 형태인 그래픽 노블의 공급과 소비가 폭발적으로 늘게 되었다. 그리고 이러한 만화의 대중화는 만화책의 유통을 매니아층이 찾는 만화 전문 소매점에서 일반 인들도 쉽게 구매할 수 있는 슈퍼마켓, 편의점, 일반서점 등으로 유통 접점을 확장하며 
그래픽 노블의 영향력을 강화하였다.

미국은 다른 국가와는 차별화되는 특이한 시장 구조를 지니는데 전체 출판 만화시장 의 $80 \%$ 이상을 마블 코믹스, DC 코믹스 두 만화 출판업체가 양분하고 있는 것이다. 시장조사업체 Statista에 따르면 2019년 기준 전체 미국 출판만화 판매 부수 중 $46.76 \%$ 를 마블 코믹스가 차지하고 있는 것으로 나타났다. DC 코믹스의 판매 부수 시장 점유율도 기준 $27.58 \%$ 로 두 업체가 출판만화는 물론 전체 미국 만화시장을 이끌고 있 다.

[그림 3-6] 미국 만화 시장의 출판사별 시장 점유율

(단위: \%)

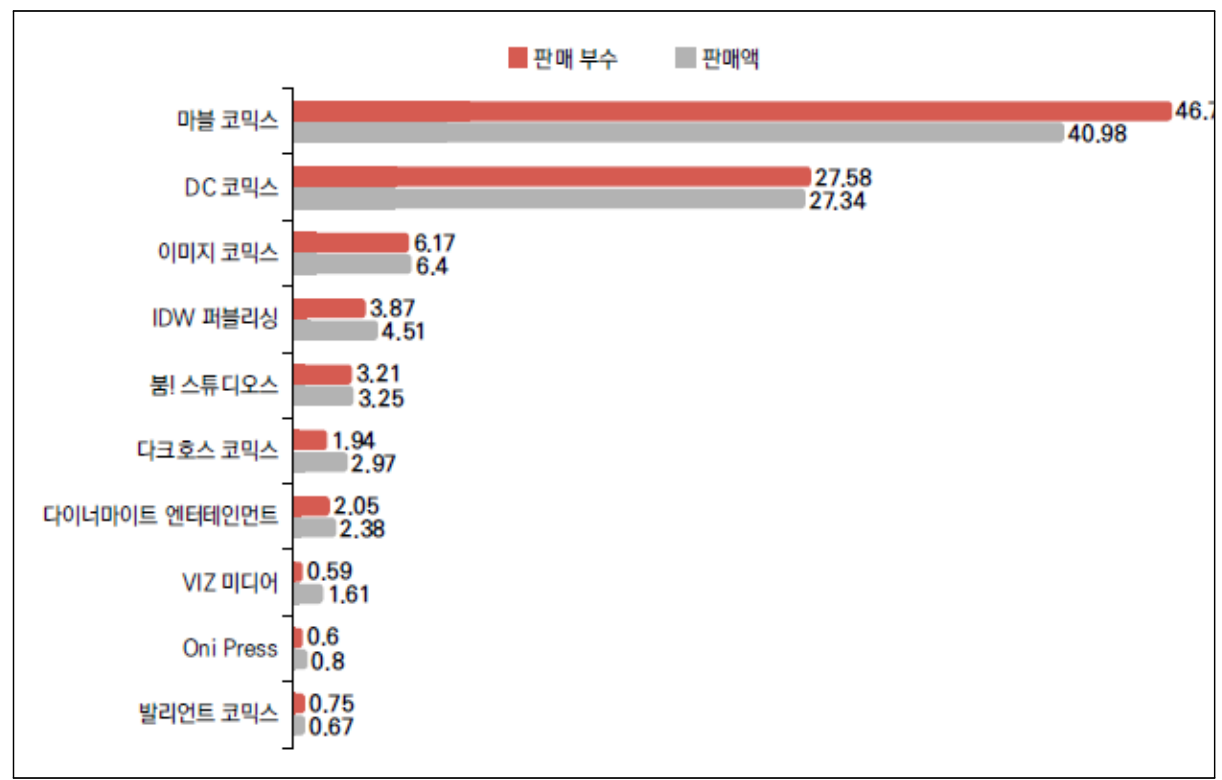

자료: Statista

\section{나. 미국 디지털 만화 주요 동향}

1) 코로나19발 오프라인 유통 붕괴와 온라인화 움직임

코로나19발 글로벌 팬데믹의 영향은 미국의 출판만화 유통에 직격탄을 날렸다. 마블 코믹스와 DC 코믹스는 물론 미국 오프라인 만화의 공급과 유통을 거의 독점하고 있는 다이아몬드 코믹스(Diamond Comics)가 만화 유통을 중단하게 된 사례가 발생했기 때 문이다. 코로나 19 발 팬데믹의 영향으로 만화책을 취급하는 소매 업체의 매출이 급락한 
데에서 비롯되었다.

이러한 상황이 중요한 이유는 마블 코믹스나 DC 코믹스 등 주요 출판사들이 온라인 유통에 눈을 돌리게 되었다는 것이다. 사실 미국에서는 2010년대 중만 코믹솔로지 등을 중심으로 디지털 유통의 시도를 공격적으로 진행된 바가 있었지만 큰 성공을 거두지 못 하면서 디지털 만화가 자리를 잡지 못했었다. 그러나 이번 코로나 19발 디지털화 촉진은 만화산업도 피해가기 어렵게 만든 것이다. 대표적으로 마블코믹스와 DC코믹스 모두 디 지털 퍼스트 전략을 각각 발표하며 히어로물들을 중심으로 디지털화를 적극 시도하고 있다.

\section{2) 스튜디오 시스템으로 인한 고용 불안정과 저작권 문제}

북미 만화가들은 프로젝트별 단기 고용 계약과 자신이 만든 작품에 대한 저작권을 포 기해야 하는 상황으로 인해 예술가로서 정체성이 크게 위협을 받고 있다. 더불어 프리랜 서로 일하는 용역 채용으로 만기적 고용 불안에 시달리는 프레카리아트 노동자로 대우 받고 있다. 현재 역량 있는 작가들이 디지털 만화 시장으로 유입되어 활동할 수 있도록 하기 위해서는 현 스튜디오 시스템의 단점을 보완하고 작가로서 창의성을 발휘할 수 있 는 고용 시스템과 수익 배분을 세우는 것이 필요하다. 기존의 인쇄 출판 만화의 시스템 에서는 만화가는 예술가가 아닌 기술자로 여겨지며, 단기 작업으로 고용이 끝나는 형태 로 인해 온전한 만화-예술가의 정체성과 수익이 보장받지 못하고 있다. 이에 반해 디지 털 유통 및 판매는 소비자가 직접 취향대로 작품을 선택하고 웹상에서 콘텐츠를 접근하 여 읽는 방식을 갖기 때문에 창작자들이 큰 관심을 보이고 있다. 즉, 디지털 만화는 대형 출판사와의 계약이 필요 없고 작가의 자유가 보장되며 슈퍼 히어로 장르 등 기존에 편중 된 미국 만화 장르가 아닌 다양한 장르의 만화의 시도가 가능하다는 유입요인이 나타나 고 있는 것이다.

\section{3) 아직까지 주도권을 갖는 디지털 플랫폼 부재}

출판시장의 $80 \%$ 를 차지하는 마블과 DC, 디스커버리 배급사의 독점 체제뿐 아니라, 디지털 만화시장도 역시 ‘빅 투’를 중심으로 한 준독과점 형태가 유지되고 있었다. 스리 벤트(Thrillbent)나 메이드파이어(Madefire)와 같은 신생 디지털 코믹스 플랫폼이 기존 
과 다른 대안 모델을 도입하며 '모션 코믹스’나 'VR, AR 코믹스'와 같은 색다른 스토리 텔링을 선보이며 경쟁했지만, 2012년에 출시한 메이드파이어는 올해 서비스를 중단했 다.47) 미국의 만화산업은 거대 출판사를 중심으로 기존의 출판만화시장에 타격을 주거 나 대체하지 않는 선에서 디지털 만화시장이 형성되어 있다고 할 수 있다. 즉 미국 코믹 스 만화의 주요 소비자층은 여전히 출판 만화를 선호하는 기존의 중장년층의 남성들이 며, 메인 출판사의 주요 관심이자 타겟 역시 이들에게 맞춰있다.

\section{2. 웹툰산업의 미국 진출 현황}

\section{가. 국내 웹툰 플랫폼의 미국 앱(app) 시장에서의 선전}

2014년부터 네이버 웹툰은 미국 시장 진출을 시작하여 유의미한 성과를 창출하고 있 다. 시장조사 기관인 앱애니에 따르면 네이버 웹툰은 2021년 8월 기준 구글 플레이스토 어 만화앱 부문에서 수익 1위를 기록했으며, 2019년 말부터 월간 순 방문자(MAU)는 1000 만 명 이상을 발생시키고 있다. 네이버 웹툰 영어 서비스에서는 약 240 개의 오리지 널 콘텐츠가 등록되어 있는데, 미국 현지 창작자 콘텐츠가 150 여 개를 차지하고 나머지 90 여 개는 한국 웹툰 콘텐츠로 구성되어 있다. 네이버에 따르면 네이버 웹툰 영어 서비 스 주요 이용자들 중 과반 이상이 16 24세 사이의 연령대 인 것으로 나타났다.

네이버 외에도 만타, 타파스, 태피툰, 포켓코믹스 등 앱 다운로드와 수익에서 한국 웹 툰 플랫폼들이 상위권을 휩쓸고 있다.눈에 띄는 점은 카카오에서 인수한 타파스, $\mathrm{NHN}$ 이 운영하고 있는 포켓코믹스 외에도 만타, 태피툰 등 한국의 중소 플랫폼들 역시 상위 권을 기록하며 선전 중이라는 것이다.

47) (참고) https://techcrunch.com/2021/04/29/madefire-shuts-down.html 
[그림 3-7] 구글 플레이스토어 만화 부문 인기 및 수익 차트(2021년 8월 18일 기준)

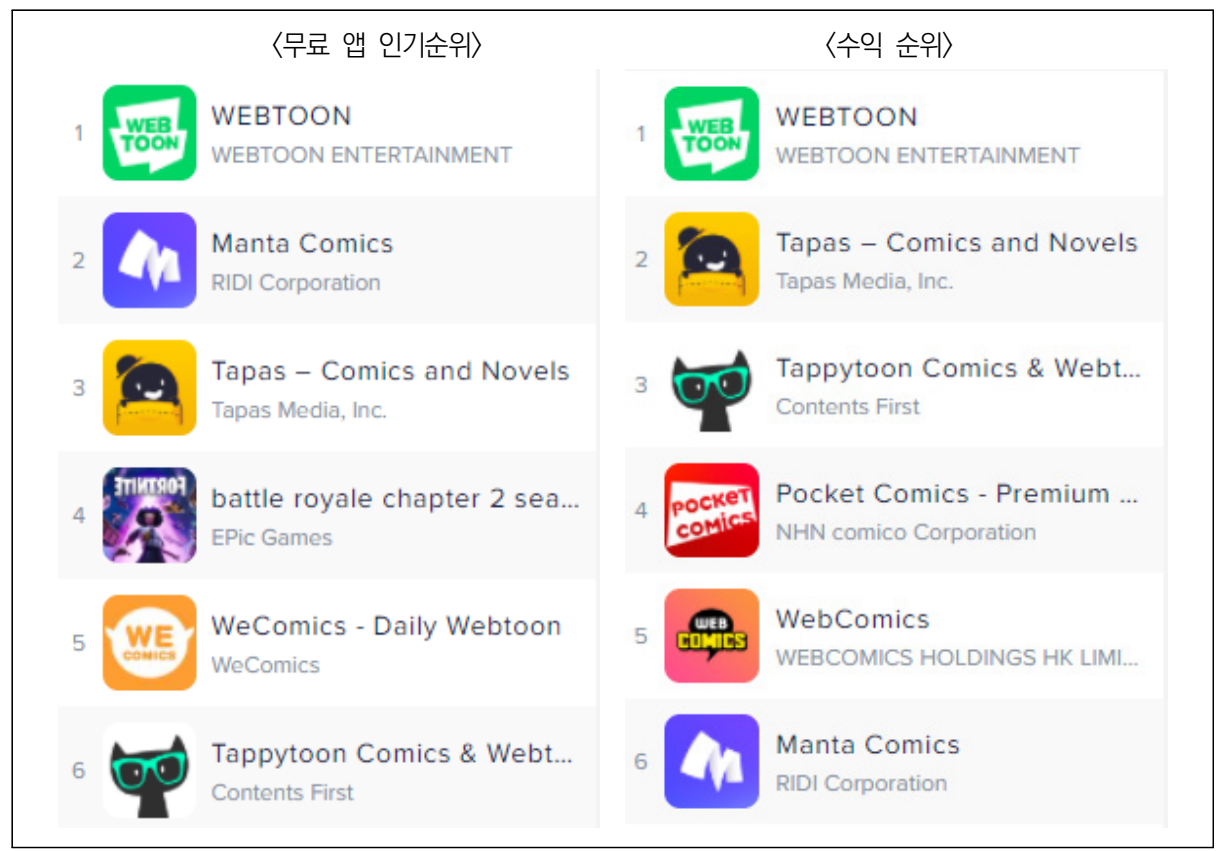

자료: 앱애니(https://mww.appannie.com/)

월 정액 $\mathrm{e}$ 북 서비스인 리디북스의 성공으로 유명한 콘텐츠 기업 리디는 월구독 방식 을 웹툰에 적용한 월구독 웹툰 플랫폼 '만타(manta)'를 출시하였다. 만타는 2020년 11 월에 미국에 진출하였으며, 진출 4개월 만인 2021년 3월 구글플레이 만화 부문에서 인 기 무료 앱 순위 1 위를 차지하는 등 시장에 안착하였다.

태피툰 역시 2016년 한국의 스타트업 기업인 콘텐츠퍼스트가 내 놓은 웹툰 플랫폼이 며 DNC 미디어, 키다리스튜디오, 학산문화사 등 유명 한국 웹툰 제작사들과 계약을 맺 어 $100 \%$ 한국 웹툰 콘텐츠로만으로 구성하였다. 이들 직원 중 무려 $25 \%$ 정도가 번역 검수의 일을 담당하고 있으며, 의성어·의태어의 번역하는 인원이 별도로 있을 정도로 고 급 번역에 힘을 쓰고 있다. 이들 콘텐츠 중 대다수는 한국 제작사들과 독점 수출 계약을 맺고 해외진출이 진행되고 있다. 


\section{나. 현지화를 위한 적극적인 M\&A 및 구조변경}

국내의 네이버와 카카오는 미국 현지의 웹툰과 웹소설 업체들을 인수하며 공격적인 현지화를 시도할 것으로 예측된다. 네이버는 월 이용자 수가 9400만명에 달하는 미국의 웹소설 1 위 플랫폼 '왓패드’를 인수하였다. 왓패드가 보유한 창작자 수는 570 만 명, 10 억 개의 IP를 활용하여 현지에 최적화된 웹툰 제작에 나설 것으로 예상된다. 네이버는 보도를 통하여 이미 한국에서 검증된 사업 모델인 부분 유료, 광고, IP 비즈니스로 이어 지는 'PPS 프로그램(Page Profit Share Program)'을 적용하여 작가에 원고료 외 수입 을 제공할 예정임을 알렸다.

카카오엔터테인먼트도 2020 년 미국의 최초 웹툰 플랫폼인 타파스의 지분 $100 \%$ 를 확 보하며 미국시장 진출을 본격화하였다. 또한 2016년 미국 뉴욕에 설립된 웹소설 플랫폼 인 '레디쉬’를 인수하여 집단 창작 시스템을 바탕으로 한 자체 제작 콘텐츠 '래디쉬 오리 지널'을 활용한 IP사업을 확장할 계획이다.

한편 네이버 웹툰은 본사를 글로벌 사업 확장에 용이한 미국의 웹툰엔터테인먼트에 두고 공격적인 미국시장 진출을 예고하고 있다. 네이버는 2020년 5월 한국(네이버웹 툰)·미국(웹툰엔터테인먼트)· 일본(라인디지털프론티어)로 나뉘어있던 기업들을 미국 웹 툰엔터테인먼트에 통합다. 이는 거점을 미국으로 옮겨 국내외 웹툰 IP 기반 수익사업에 적극적으로 나서고자 하는 방향성이 드러나는 부분이다. 국내에서도 웹툰 원천을 활용해 영화, 드라마, 게임, 애니메이션 등의 타 장르 콘텐츠 제작에 활용하여 성과를 창출했던 것처럼 웹툰을 해외에서도 콘텐츠 시장의 핵심적인 원천 자원으로 투자하여 장기적인 성장을 계획하고 있다. 
[그림 3-8] 네이버 웹툰 사업 지배구조도(단위: \%)

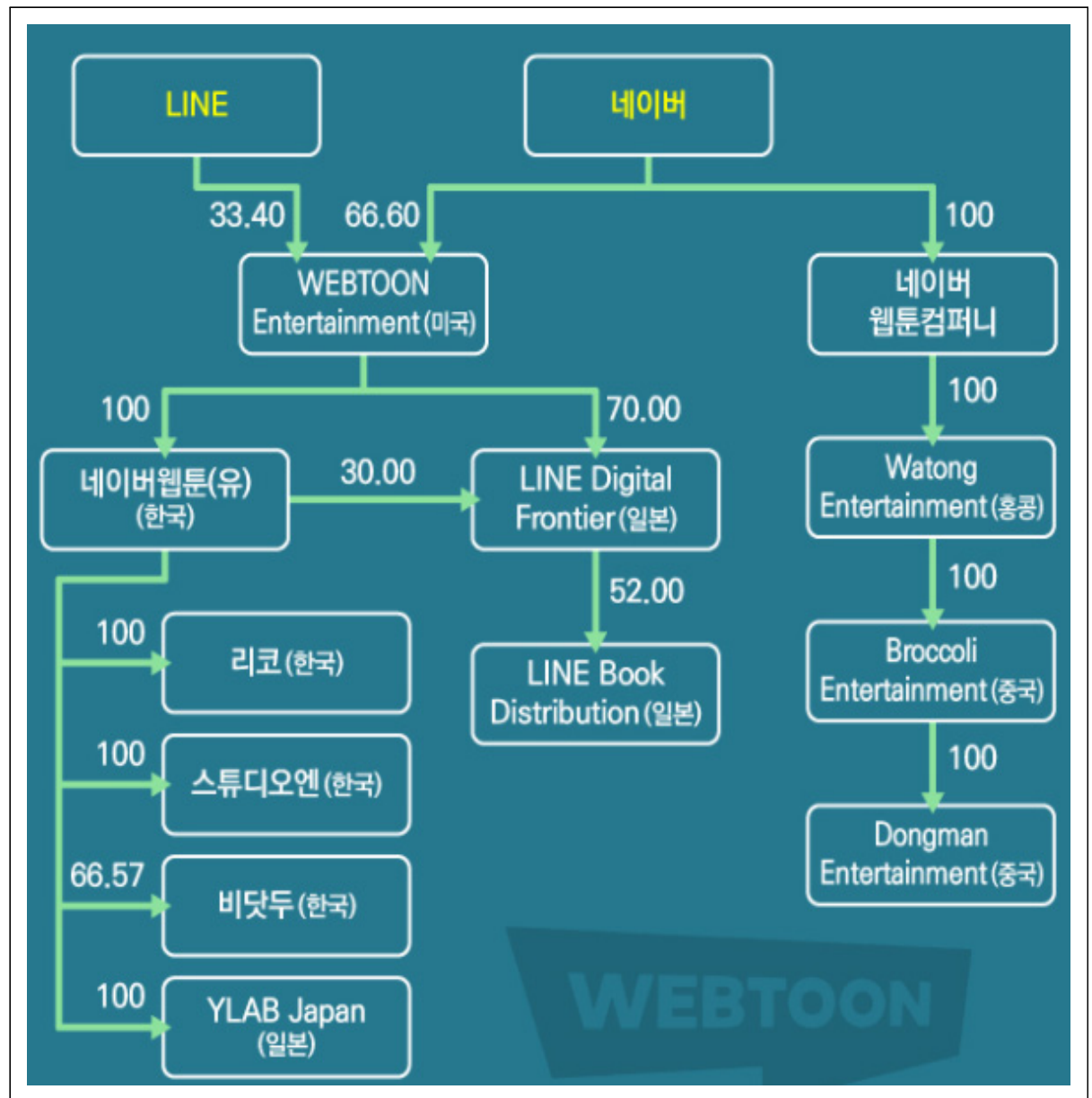

자료: Business watch, K-웹툰, 시작은 미약했다, 2021.08.07. 


\section{제3절 유럽 현황}

\section{1. 유럽 디지털 만화 시장 현황}

\section{가. 유럽의 디지털 만화 시장 현황}

PWC에 따르면, 영국의 만화 산업은 1960 년대와 70 년대에 영국 만화산업은 황금기 를 누렸으나 이후로는 수축과 정체를 반복하는 중이다. 영국의 만화시장 크기는 2019년 기준 2억 2,500만 달러로 2017년 이후 지속적으로 하락세를 유지하고 있다. 이는 출판 산업 자체가 겪고 있는 지속적인 불황의 여파가 출판만화에 미쳤기 때문이며, 슈퍼히어 로를 내세우는 미국 만화작품의 수입으로 인해 경쟁 구도에서 뒤처지고 있기 때문이다.

[그림 3-9] 영국 만화시장 규모 및 성장률

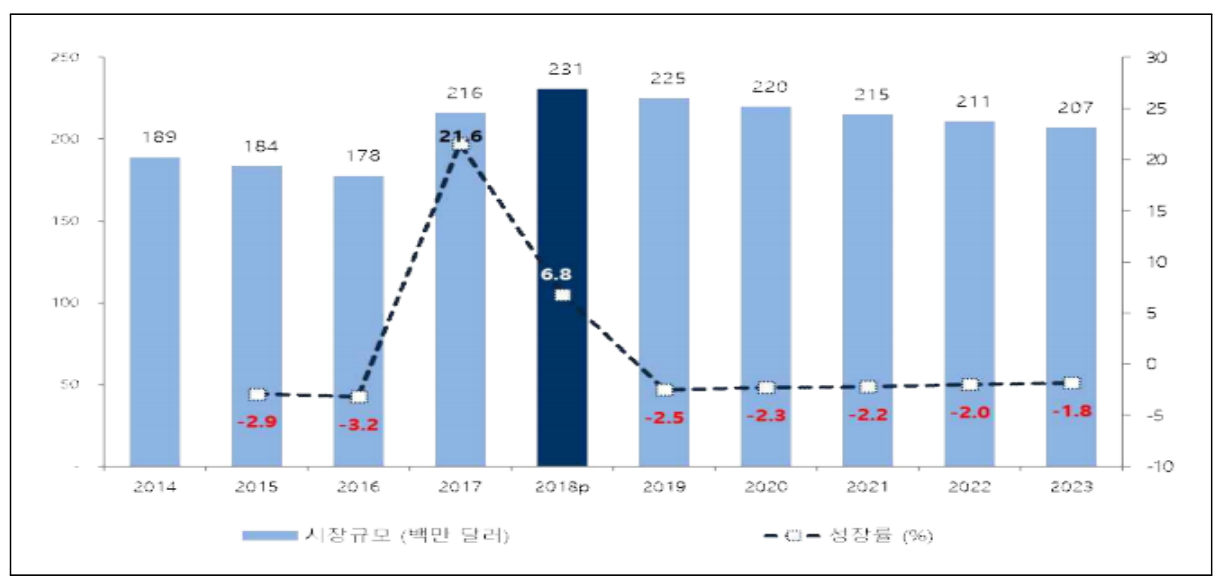

자료: 2019 해외 콘텐츠시장 분석(한국콘텐츠진흥원, 2019)

프랑스에서 만화(BD: Bande dessinee)는 소위 9번째 예술로 불리는 등 그 위상이 높으며 세계 만화시장 규모 4위를 차지하고 있다. 독일 조사기관 GFK에 따르면, 2016 년부터 2020년까지 꾸준히 성장세를 보여주고 있으며 매출액은 이 기간 동안 $6 \%$ 증가 
한 5억 9,100만 유로를 기록하였다. 특이한 점은 2020년엔 특히 일본 만화의 성장세가 두드러졌는데, 2019년에 비해 $18 \%$ 성장했으며, 프랑스 만화 시장의 무려 42\%가 일본 만화가 점유하고 있었다.

영국, 프랑스, 독일 등 유럽에서는 아직 디지털 만화보다는 출판만화의 소비가 아직 많지만 디지털 규모는 잠재력이 높다. 세계 디지털만화 시장에서 유럽의 비중은 2013년 $22.9 \%$ 에서 2017 년 25.6\%로 2.7\% 성장했고, 2022년에는 26.6\%로 3.9\%의 추가 성장 이 예상되는 등 향후 지속적으로 확대될 것이라 전망된다. 유럽 디지털만화 시장의 규모 와 성장률은 급격히 증가해왔으며 2013 년 1억 1,700만 달러였다가 2015년 1억 7,600 만 달러, 2017년 2억 3,300 만 달러로 4년 동안 2배 성장하였다.

[그림 3-10] 유럽 디지털 만화 시장 규모 및 전망

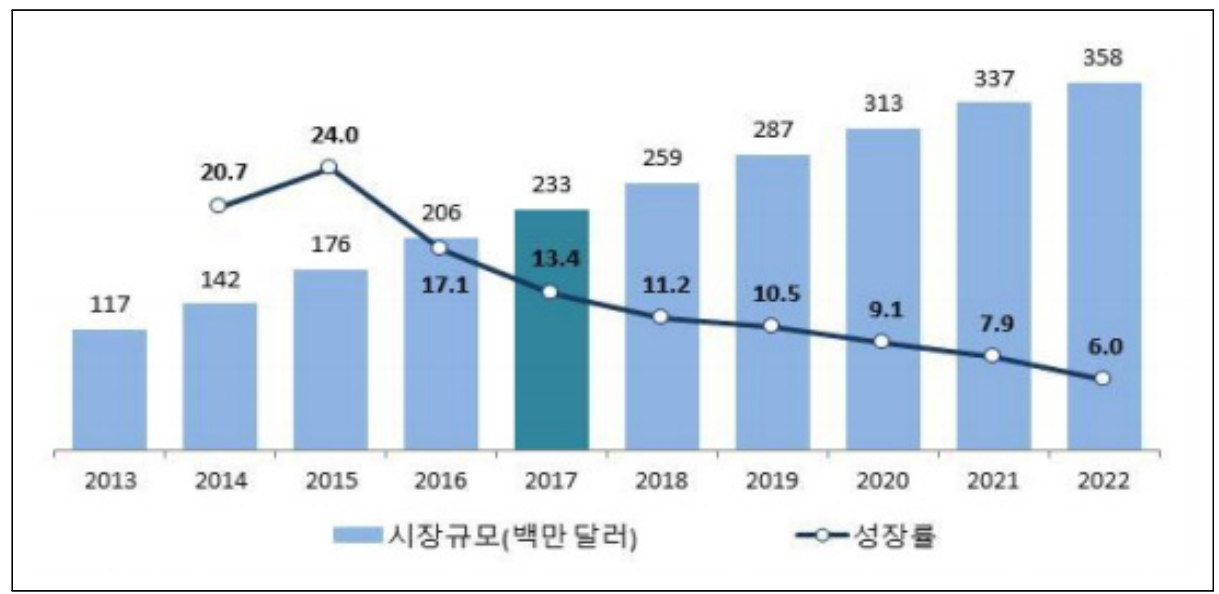

자료: 2019 해외 콘텐츠시장 분석(한국콘텐츠진흥원, 2019)

\section{나. 유럽 디지털 만화 경쟁 구조 및 주요 동향}

유럽에서도 2010년부터 디지털만화 플랫폼이 등장하였으며 유럽 출판사들끼리 연합 한 디지털 플랫폼도 등장하였다. 유럽 최초의 디지털만화 플랫폼은 2010년에 시작된 프 랑스의 '이즈네오'이며 현재 2 만 종 이상의 만화, 코믹스, 망가, 그래픽노블을 서비스하 고 있다. 유럽 13개 만화책 출판사들이 2015 년 공동 설립한 ‘유럽코믹스'는 디지털만 화 플랫폼으로, 1 천종이 넘는 유럽 만화 작품을 문학유산으로 인식하고 영어로 번역해 해외에 소개하는 것을 목적으로 운영되고 있다. 유럽코믹스의 파트너 출판사들은 영국의 
시네북(Cinebook), 프랑스의 다르고(Dargaud)와 메디아툰 라이센싱(Mediatoon Licensing) 그리고 엘립스아님 프로덕션(Ellipsanime Productions), 이탈리아의 바오 퍼블리싱(BAO Publishing)과 투누에(Tunué), 스페인의 디북스(Dibbuks) 등 8 개국 13 개에 달한다.

[그림 3-11] 유럽 디지털 만화 시장 규모 및 전망

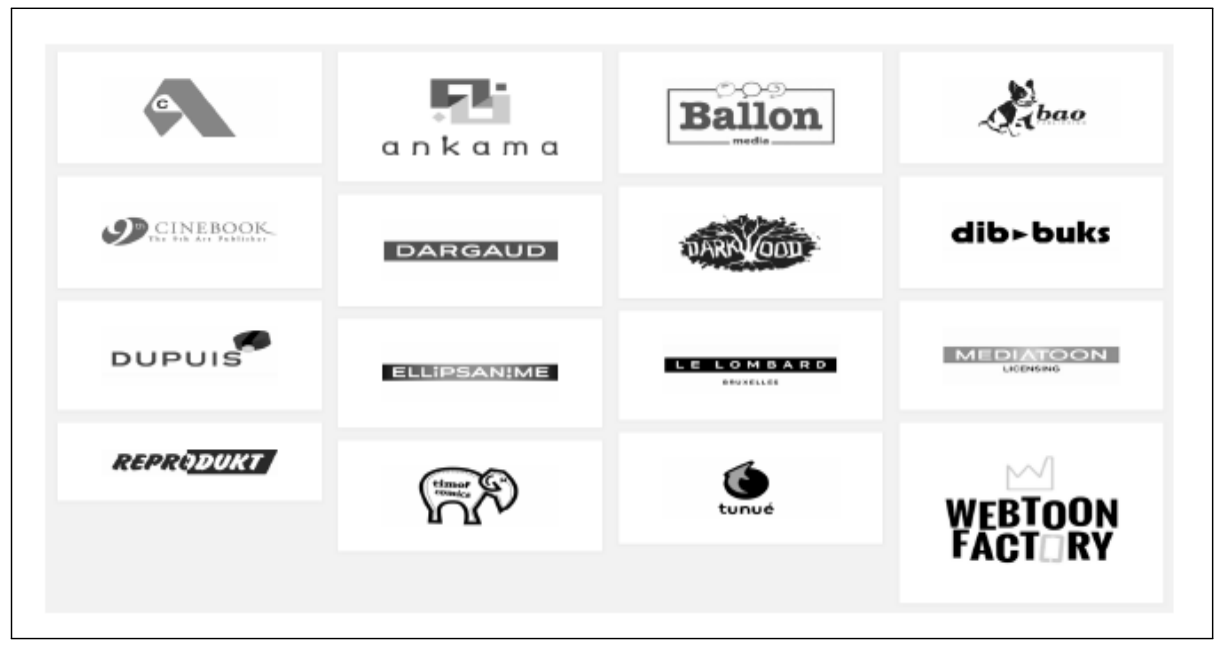

미국 아마존에서 운영하는 디지털 만화 플랫폼 코믹솔로지(ComiXology)는 2013 '코믹솔로지 유럽(ComiXology Europe)' 서비스를 시작해서 현재 영어판과 불어판으 로 운영되고 있으며, 프랑스 만화전문 출판사 델쿠르(Delcourt)와의 콘텐츠 제휴를 시 작으로 유럽코믹스 등 여러 만화 판권 소유자들의 작품을 폭넓게 서비스 하고 있다.

영국에서는 출판만화의 약세에 대응하기 위해 만화 출판사들은 경쟁적으로 디지털화 를 시도하고 있는데 1938년에 창간해 80년 넘게 명맥을 유지해온 영국 최장수 만화잡 지 '더 비노(The Beano')는 2017 년부터 게임, 퀴즈, 영상을 함께 서비스하는 종합적인 콘텐츠 포털사이트를 개설함으로써 디지털화를 시도하고 있다. 또한 SF 만화 전문잡지 '투사우전드 에이디(2000 AD)'는 리벨리온 2015년 디지털저작권(DRM)을 제거한 모바 일 전용 앱을 발표해 $\mathrm{PDF}$ 파일로 다운로드 받을 수 있도록 서비스 방침을 바꾸었다. 그 외에 만화잡지 '코만도(Commando)'는 2010 년에 발간한 제 4,342호부터 디지털 만화 서비스인 코믹솔로지를 통해 온라인 서비스를 시행하고 있다. 


\section{2. 웹툰의 유럽 진출 현황}

\section{가. 현지에서도 웹툰 플랫폼 발생}

프랑스에서는 한국 사업자들이 진출한 웹툰 플랫폼 외에도 한국의 웹툰 형식을 그대 로 적용한 자체 플랫폼을 개발하여 서비스하고 있다. 2017년에 시작한 프랑스 웹툰 플 랫폼 ‘웹툰팩토리’는 프랑스의 유명 출판사 Dupuis가 유럽 만화작가를 위주로 구성한 웹툰 플랫폼으로 그림체와 스토리의 현지화를 통해 프랑스식 웹툰으로 제작하여 서비스 한다. 2011년에 프랑스에서 시작한 프랑스 웹툰 플랫폼 델리툰은 한국의 작품을 프랑스 현지에 알리는 첨병역할을 했으며 2021년에는 한국의 웹툰사인 키다리스튜디오에 인수 되었다. 프랑스 내 윕툰 저변 확대를 위해 제 1 회 윕툰 공모전을 개최하기도 하였고, 최 근인 2021년 프랑스 출판사 Delcourt가 시작한 웹툰 서비스 베리툰도 '나 혼자만 레벨 업'과 같은 한국의 유명 작품을 들여와 프랑스의 웹툰을 적극적으로 확산시키고 있다.

〈표 3-2〉프랑스 웹툰 플랫폼 현황

\begin{tabular}{|c|c|c|c|c|c|}
\hline 구분 & $\begin{array}{c}\text { Delitoon } \\
\text { 델리툰 } \\
\text { delit@on }\end{array}$ & $\begin{array}{c}\text { Webtoon Factory } \\
\text { 웹툰팩토리 } \\
\text { WEBTOON } \\
\text { FABTDRY }\end{array}$ & $\begin{array}{c}\text { Verytoon } \\
\text { 베리툰 } \\
\text { VVVErjjonon }\end{array}$ & $\begin{array}{l}\text { Webtoon Line } \\
\text { 웹툰 라인 } \\
\text { wEB } \\
\text { Toow }\end{array}$ & $\begin{array}{c}\text { Izneo } \\
\text { 이즈네오 } \\
\text { izneo }\end{array}$ \\
\hline 론칭 연도 & $\begin{array}{c}2011 \\
2016 \text { (어플) }\end{array}$ & $\begin{array}{c}2017 \\
2019 \text { (어플) }\end{array}$ & 2021 & 2019 & 2010 \\
\hline $\begin{array}{l}\text { 대표자/ } \\
\text { 관리업체 }\end{array}$ & $\begin{array}{c}\text { Didier Borg } \\
\text { 키다리 스튜디오 } \\
\text { (한국, 2021년 지분 } \\
\text { 인수) }\end{array}$ & $\begin{array}{c}\text { Dupuis } \\
\text { (프랑스 출판사) }\end{array}$ & $\begin{array}{c}\text { Delcourt } \\
\text { (프랑스 출판사) }\end{array}$ & 네이버 라인 & $\begin{array}{c}\text { Fnac/Darty } \\
\text { 도서/가전 판매 전문 업 } \\
\text { 체 }\end{array}$ \\
\hline 콘텐츠 & 한/중/일 작가 위주 & 유럽 작가 위주 & 한국 작가 & 네이버 웹툰 & $\begin{array}{l}\text { 웹툰과 전자책 } \\
\text { (일본 만화 포함) }\end{array}$ \\
\hline $\begin{array}{c}\text { 현재 플랫 } \\
\text { 폼 내 가장 } \\
\text { 인기있는 } \\
\text { 작품 }\end{array}$ & $\begin{array}{c}\text { 빌과 그림자 } \\
\text { (한국) }\end{array}$ & $\begin{array}{c}\text { My Demon } \\
\text { Secretary(인도네시 } \\
\text { 아) } \\
\text { Imaginary Dave } \\
\text { (프랑스) }\end{array}$ & $\begin{array}{c}\text { 나 혼자만 레벨업 } \\
\text { (한국) }\end{array}$ & $\begin{array}{l}\text { 여신강림 } \\
\text { (한국) }\end{array}$ & $\begin{array}{c}\text { 진격의 거인 } \\
\text { (일본, 전체 콘텐츠 기 } \\
\text { 준) } \\
\text { 머글의 법칙 } \\
\text { (한국, 웹툰 기준) }\end{array}$ \\
\hline
\end{tabular}

자료: 유럽주요국의 만화 및 디지털만화 시장 현황(한국콘텐츠진흥원, 2021) 


\section{나. 망가(일본만화)를 좋아하는 젊은 층을 중심으로 소비가 확산}

웹툰은 그림체 등 유럽에서는 일본 만화와 유사하게 느껴지고 있어서 일본 만화나 애 니메이션 독자를 빠르게 유입하고 있다. KOTRA 프랑스 자체 설문조사 결과48)에 따르 면 한국 웹툰을 보고있는 구독자 중에 $44 \%$ 가 일본 애니메이션을 즐겨본다고 답했고 $42 \%$ 는 일본 만화(Manga)의 팬이라 답하였다. 반면 프랑스 출판 만화인 $\mathrm{BD}$ (방드 데시 네(bande dessinée)의 팬이라고 응답한 독자는 $25 \%$ 에 불과하였다. 일반적으로 유럽에 서는 유럽 만화를 코믹스(comics), 일본만화를 망가(manga), 미국만화 그래픽노블 (graphic novel)로 3가지 장르로 나눠서 지칭하는데 이 중 웹툰은 일본만화와 독자층이 유사한 편이다.

유럽에서도 웹툰의 주요 독자층은 디지털 기기와 친숙한 젊은 세대에 속한다. 한국과 마찬가지로 스마트폰에 익숙한 MZ세대가 웹툰을 선호하고 있으며 특히 와이파이가 대 중교통과 대중시설에 확대되면서 젊은 세대를 중심으로 출퇴근이나 이동 중에 이용하는 콘텐츠로 성장 중이다.

\section{다. 여전히 인지도 부족}

웹툰의 현지 성장률은 매우 높지만 아직까지 인지도가 부족하며 마이너한 영역에 속 한다. KOTRA 설문조사에서 웹툰을 아느냐는 질문에 대해 $66 \%$ 나 웹툰에 대해 모른다 고 답변했고 겨우 웹툰을 본 적 있는 답변자는 $16 \%$ 에 불과하였다. 한편, 웹툰을 본 경험 이 있는 답변자를 대상으로 얼마나 보는지에 대한 물음을 했을 때, $21 \%$ 가 매일 보는 이용자였고, 일주일에 4 6회는 19\%, 일주일에 1 3회는 21\%를 차지하는 등 한번 독자 로 유입되면 충성도가 높은 독자가 되는 모습을 보였다.

48) 프랑스, 웹툰 시장에 주목하다, KOTRA(2021), KOTRA 파리 무역관이 프랑스인 537명을 대상으로 설문조사 
[그림 3-12] 성별과 나이에 따른 웹툰 구독과 인식(프랑스)

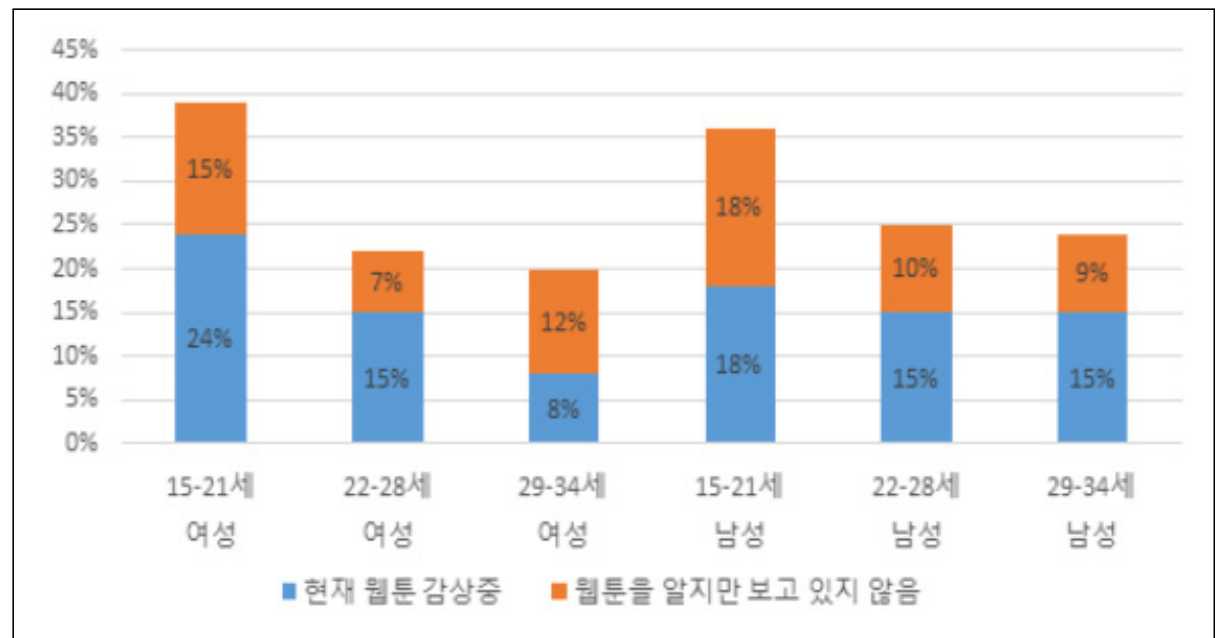

자료: KOTRA 파리 무역관 자체 조사(2021) 


\section{제4절 동남아시아 현황}

\section{1. 동남아시아 디지털 만화 시장 현황}

\section{가. 동남아시아의 디지털 만화 시장 현황 및 동향}

1) 동남아시아 만화 및 디지털 만화 시장 규모

동남아시아는 소득이 증가하면서 콘텐츠에 대한 수요가 늘어 만화산업의 시장규모가 꾸준히 증가하고 있다. PWC에 따르면 태국 만화시장은 전년 대비 7.9\% 성장하여 2019 년 기준으로 4,500만 달러 규모를 형성하였다. 또한 인도네시아 만화시장 규모는 전년 대비 $5.7 \%$ 증가하여 2018년 기준으로 850만 달러 수준인 것으로 나타났다.

\section{[그림 3-13] 인도네시아 만화시장 규모 및 성장률}

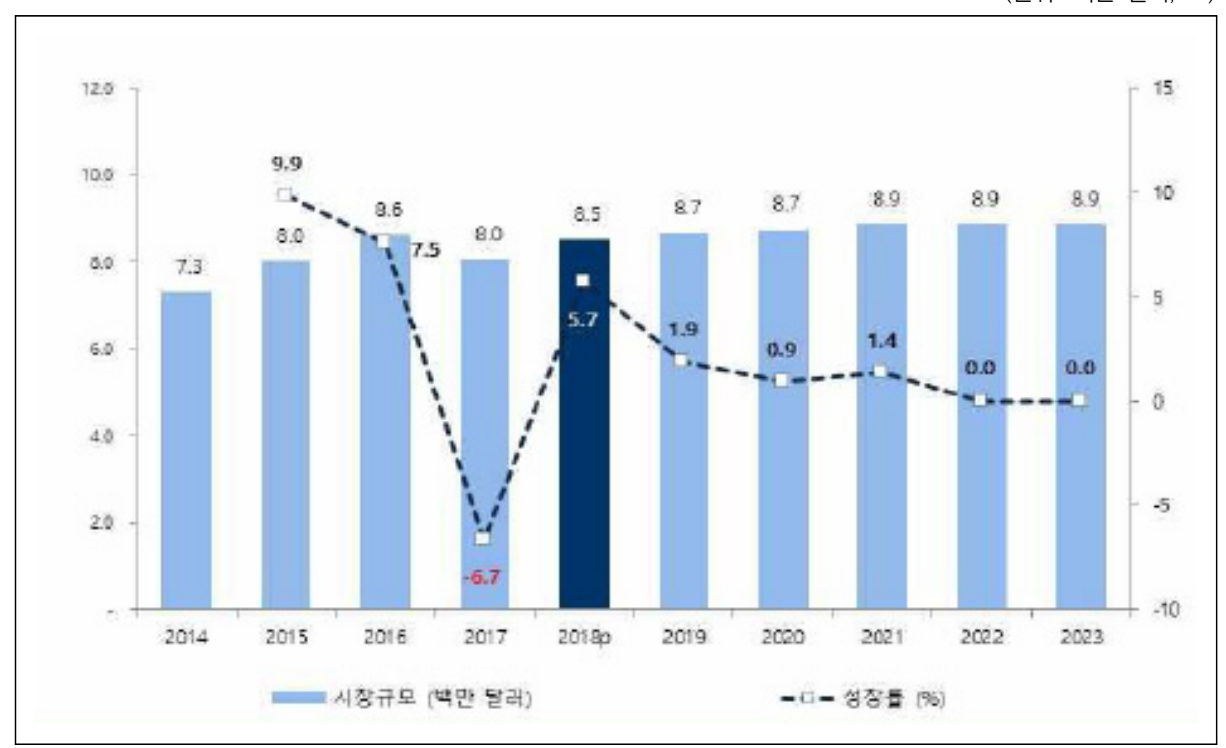

자료: 2019 해외 콘텐츠시장 분석(한국콘텐츠진흥원, 2019) 


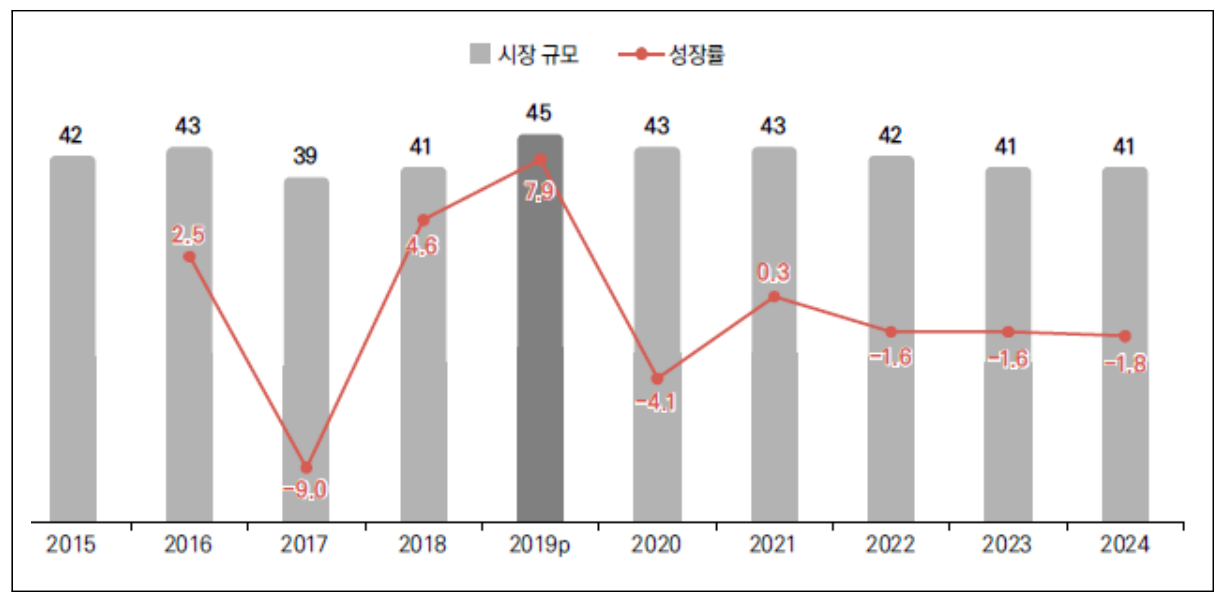

자료: 2019 해외 콘텐츠시장 분석(한국콘텐츠진흥원, 2019)

동남아시아는 1990 년대 본격적으로 일본의 만화 및 애니메이션이 들어오면서 그 수 요가 확산되었으며 일본 만화의 영향을 많이 받은 편이다. 한류 등을 통해 드라마에서는 한국콘텐츠가 인기가 많지만 만화에서는 일본 만화가 큰 인기를 끌고 있다. 실제로 일본 설문조사 업체 리코리스에 따르면, 2017년 인도네시아인을 대상으로 한 설문조사에서 $76.45 \%$ 가 일본 만화와 애니메이션에 관심이 있다고 응답하는 등 관심도가 매우 높다. 물론 웹툰을 중심으로 한국 만화의 인기도 높은 성장세를 보이고 있지만 기본적으로 일본만화를 좋아하는 층이 한국만화로 유입되는 경우가 많다.

\section{나. 동남아시아 디지털 만화 경쟁 구조 및 주요 동향}

동남아시아의 디지털 만화 시장은 웹툰이 주된 유통 경로로 자리 잡았으며, 이에 따라 한국 웹툰 플랫폼들이 시장을 선도하고 있다. 라인웹툰과 카카오페이지, 코미코와 같은 동남아시아에 진출한 한국 웹툰 플랫폼들은 동남아시아 대부분 국가에서 최상위권을 차 지하고 있다.

웹툰의 인기가 높아지자 동남아시아 각 국가에서도 현지의 웹툰 플랫폼들이 나타나며 디지털 만화시장의 성장을 견인하고 있다. 인도네시아 현지에서 '찌아요 코믹스', '레온 코믹스' 등 현지 플랫폼들이 현지 만화작가 발굴하면서 꾸준히 성장 중이다. 한편 태국 
에서는 현지 e북 기업인 ‘욱비'가 서비스하고 있는 ‘위코믹스'가 큰 인기를 끌고 있는데, 시장조사업체 앱애니에 따르면 2020년 10월을 기준으로 현지의 구글 플레이 스토어 만 화 앱 부문 다운로드 수 1 위, 수익 순위 15 위를 차지한 것으로 나타났다. 위코믹스는 현지 콘텐츠와 함께 한국과 중국 등 다수의 해외 콘텐츠 공급업체와 협력을 통해 콘텐츠 를 확보하여 현지 콘텐츠 뿐 아니라 다양한 국가의 콘텐츠를 제공 중이다.

〈표 3-3〉 인도네시아 및 태국 현지 웹툰 플랫폼

\begin{tabular}{|c|c|c|c|}
\hline 플랫폼 명 & 국가 & 특징 & 런칭일 \\
\hline $\begin{array}{l}\text { 찌아요 } \\
\text { (Ciayo) }\end{array}$ & 인도네시아 & $\begin{array}{c}\text { 처음부터 웹으로 개발한 } \\
\text { 앱으로 } \\
\text { 자체적으로 현지작가 발굴 }\end{array}$ & 2016.12 \\
\hline $\begin{array}{c}\text { 레온 } \\
\text { (Re:On) }\end{array}$ & 인도네시아 & $\begin{array}{l}\text { 지역만화가 포럼에서 시작 } \\
\text { 인쇄버전 현지만화를 } \\
\text { 스캔한 스캔만화도 제공 } \\
\text { 모바일 버전 미지원 }\end{array}$ & 2013.07 \\
\hline $\begin{array}{c}\text { 바짜꼬믹 } \\
\text { (BacaKomik) }\end{array}$ & 인도네시아 & $\begin{array}{c}\text { 가장 최근에 } \\
\text { 출시한 인도네시아 } \\
\text { 웹툰 플랫폼 }\end{array}$ & 2020.04 \\
\hline $\begin{array}{c}\text { 위코믹스 } \\
\text { (Wecomics) }\end{array}$ & 태국 & $\begin{array}{c}\text { e북기업 욱비의 자회사 } \\
\text { 태국만화 중심이지만 } \\
\text { 제휴를 통해 한국, 중국, 일본 } \\
\text { 만화 제공 }\end{array}$ & \\
\hline
\end{tabular}

자료: 베트남 만화산업, 한국콘텐츠진흥원(2020). 인도네시아 만화 콘텐츠 동향, 한국콘텐츠진흥원(2020) 종합

동남아시아는 국가마다 선호하는 웹툰의 장르와 취향에 차이가 있다. 태국은 '여신강 림', '어느 날 공주가 되버렸다', '재혼 황후' 등 여성향 로맨스 작품이 상위 순위의 대부 분을 차지하고 있으며, $\mathrm{BL}$ 물의 인기도 높은데 비해 인도네시아는 드라마, 로맨스 장르의 인기가 높은 편이다. 


\section{2. 웹툰산업의 동남아시아 진출 현황}

\section{가. 국내 웹툰 플랫폼이 디지털 만화 시장을 선도}

동남아시아의 디지털 만화 시장은 한국에서 진출한 웹툰 플랫폼들이 우위를 차지하고 있다. 인도네시아에서는 국내의 라인웹툰, 카카오페이지, 토리코믹스, 코미코가 가장 많 이 이용한 디지털 만화 서비스에서 1 위에서 4 위를 차지하고 있다. 특히 라인 웹툰은 태 국에서 가장 많이 이용하고 있는 메신저 '라인'의 인프라를 활용하여 현지 시장을 공략 하였다. 로맨스나 액션 장르 등 10 대에서 20대 초반의 연령을 대상으로 소년·소녀 만화 가 인기를 끌고 있다. 또, 현지 공모전 등을 현지 작가를 발굴하고 있는데 이를 통해서 디지털 만화의 표준을 웹툰 인식하게 하는데 성공하였다.

〈표 3-4〉 인도네시아 디지털 만화 서비스 이용 순위

\begin{tabular}{|c|c|c|c|c|c|}
\hline 순번 & 업체 로고 & 서비스명 & 득징 & $\begin{array}{l}\text { 인도네시아 } \\
\text { 출시일 }\end{array}$ & 국가 \\
\hline 1 & & $\begin{array}{c}\text { 라인 웹툰 } \\
\text { (LINE Webtoon) }\end{array}$ & $\begin{array}{c}\text { 웹툰 서비스를 현지 시장에 소개 } \\
\text { 현지 작가 발굴 프로그램 운영 } \\
\text { AOS 매출 순위 } 1 \text { 위 }\end{array}$ & 2014.07 & 한국 \\
\hline 2 & & $\begin{array}{l}\text { 카카오페이지 } \\
\text { (Kakaopage) }\end{array}$ & $\begin{array}{c}\text { 네오바자르 인수를 통한 현지 } \\
\text { 진출. 로맨스 장르 득화 } \\
\text { AOS 매출 순위 } 6 \text { 위 }\end{array}$ & 2018.03 & 한국 \\
\hline 3 & & $\begin{array}{l}\text { 토리코믹스 } \\
\text { (Toryworks) }\end{array}$ & $\begin{array}{c}\text { 번역 작가로 직접 참여하는 웹둔 } \\
\text { 플랫폼 } \\
\text { 글로벌 누적 } 1,000 \text { 만 다운로드 }\end{array}$ & 2017.06 & 한국 \\
\hline 4 & comico & $\begin{array}{c}\text { 코미코 } \\
\text { (Comico) }\end{array}$ & $\begin{array}{c}\mathrm{NHN} \text { 엔터에서 출시한 만화 } \\
\text { 플랫폼으로 일본 출판 만화 및 } \\
\mathrm{Re}: \mathrm{On} \text { 의 현지 출판 작품들을 } \\
\text { 공급받아 제공 }\end{array}$ & 2017.06 & 한국 \\
\hline 5 & $\begin{array}{l}\text { MANGA } \\
\text { TOON }\end{array}$ & $\begin{array}{c}\text { 망가툰 } \\
\text { (Mangatoon) }\end{array}$ & $\begin{array}{c}\text { 중국계 웹둔으로 인도네시아어 } \\
\text { 제공 } \\
\text { AOS 전체 매출 순위 } 72 \text { 위, } \\
\text { 웝툰 순위 } 4 \text { 위 }\end{array}$ & 2018.07 & 중국 \\
\hline
\end{tabular}

자료: 한국콘텐츠진흥원 인도네시아 비즈니스센터 자체조사, 2020년 7월 
〈표 3-5〉 태국에 진출한 주요 웹툰 플랫폼

\begin{tabular}{|c|c|c|c|c|}
\hline 서비스명 & 운영 업체 & 주요 콘텐츠 & 성과 & 주요 전략 \\
\hline $\begin{array}{c}\text { 웹툰 } \\
\text { (Webtoon) }\end{array}$ & 라인 & $\begin{array}{l}\text { - 네이버웹툰에서 제공하고 } \\
\text { 있는 한국 웹툰 및 태국 웹툰 } \\
\text { - 로맨스, 액션 등 소년·소녀 } \\
\text { 및 학생 대상 만화 } \\
\text { - 인기 한국 웹툰의 경우 연 } \\
\text { 재 속도가 한국과 거의 차 } \\
\text { 이가 없음 }\end{array}$ & \begin{tabular}{|l} 
- 구글 플레이스토어 만화 부 \\
문 수익 순위 1 위, 다운로 \\
드 수 2 위 \\
- 2019 년 11 월 기준 태국에 \\
서만 1,680 만 명 이상 이 \\
용자 수 달성
\end{tabular} & \begin{tabular}{|l} 
- 메신저 '라인' 기반 \\
- '기다리면 무료' 전략 \\
- 현지 웹툰 작가 발굴을 위 \\
한 공모전 매년 개최
\end{tabular} \\
\hline $\begin{array}{c}\text { 코미코 } \\
\text { (comico) }\end{array}$ & $\begin{array}{l}\mathrm{NHN} \\
\text { 엔터테 } \\
\text { 인먼트 }\end{array}$ & \begin{tabular}{|l} 
- 네이버웹툰, 카카오스토리 \\
등 한국 웹툰 및 일본 웹툰 \\
중심 \\
- 곤텐츠의 $15 \%$ 는 태국 웹툰 \\
- BL과 로맨스 중심이나 개 \\
그, 호러. 액션 만화 등도 \\
제공
\end{tabular} & \begin{tabular}{|l|} 
\\
- 구글 플레이스토어 만화 부 \\
문 다운로드 수 4 위, 수익 \\
순위 12 위
\end{tabular} & $\begin{array}{l}\text { - 태국 현지 웹툰 작가 협업 } \\
\text { 확대 } \\
\text { - 온·오프라인 만화 대회 및 } \\
\text { 세미나 } \\
\text { - '기다리면 무료' 전략 } \\
\text { - 포인트 룰렛, 할인 행사 등 } \\
\text { 프로모션 진행 } \\
\text { - 다운로드 후 오프라인 읽기 } \\
\quad \text { 기능 제공 }\end{array}$ \\
\hline
\end{tabular}

\section{나. 현지 작가 발굴}

동남아시아에서는 공모전이나 현지 작가 발굴 프로그램을 통해 현지 웹툰 작가들을 발굴하고 있다. 사실 현지의 만화 작가 지망생들은 출판시장을 통해서 데뷔할 기회를 잡기 매우 어려운 구조를 가지고 있었다. 따라서 네이버 웹툰의 CANVAS와 같은 온라 인 공모전은 이들에게 또 다른 기회가 되었으며 현지 만화가들의 성공 사례가 등장하면 서 현지 산업계에 영향을 미치고 있다. 예를 들어 태국의 '더텀(theterm)', ‘론리캣 (Lonely Cat)', '버터스위트(Butter Sweet)'는 네이버웹툰의 'canvas' 프로그램을 통해 태국에서 발굴되어 나타난 성공시례이다. '웹툰'이 만화 작가가되는 등용문의 역할을 하 게 된 것이다. 또한 경쟁 플랫폼사들도 현지에서 공모전을 개최하는 등 CANVAS의 성 공 사례를 벤치마킹하고 있다. 


\section{제5절 소결}

본 장에서는 일본, 미국, 유럽, 동남아시아 등 해외 주요국 및 주요지역의 디지털 만화 시장 현황을 살펴보면서, 웹툰산업이 해당 시장에 침투 및 진출할 수 있는 기회점을 찾 고 동시에 위협이 될 수 있는 지점들을 검토하고자 하였다. 그 결과 다음과 같은 해외진 출 기회점들과 위협점들을 도출할 수 있었다.

\section{1. 해외 현지시장의 기회점}

\section{가. 코로나19로 인한 만화의 디지털 전환요구 증대}

코로나19의 발생으로 인해 전 세계적으로 만화의 디지털 전환 요구가 높아졌고 그에 따라 웹툰의 성장 잠재력은 더욱 높아지게 되었다. 대부분의 해외 만화시장은 아직도 인쇄 출판 중심의 시장으로, 소비 및 유통도 출판물 중심이다. 전자책이 활성화되면서 디지털만화로의 전환도 이루어지고는 있었으나 그 비중이 낮았고 인쇄물을 그대로 스캔 하여 디지털화 해 놓는 수준의 만화가 많아서 모바일에서 이용하기에는 불편함이 따르 는 방식이 주를 이루었다. 코로나19로 인해 기존의 유통구조가 파괴되자 디지털 만화가 강세를 이루었고, 그러한 디지털 만화보다 더 모바일에 최적화된 방식인 웹툰이 인기를 끌고 있다. 코로나19로 인해 많은 산업이 타격을 입었지만 웹툰의 경우에는 오히려 기회 로 작용한 측면이 있다. 이는 비대면 소비가 일상화되면서 디지털 방식으로 만화를 소비 하는 것이 일상화되고 있는 측면이 있고, 웹툰이 디지털만화보다 진화된 방식이고, 연재 속도와 내용 면에서도 강점을 지녔기 때문이다. 


\section{나. 중소 플랫폼의 해외진출 기회}

현재 해외시장에서의 웹툰산업은 메이저 웹툰 플랫폼이 아니더라도 해외 수익성과를 내는 사례들이 다수 있었다. 국내 웹툰산업은 사실상 네이버, 카카오 등의 양대 플랫폼 이 주도하고 있다고 해도 과언이 아니며 해외에서도 메이저 플랫폼 기업들이 주요한 역 할을 해 온 것은 마찬가지이다. 다만, 몇몇 중소플랫폼은 해외 시장에서 괄목할만한 성 과를 내고 있어, 이러한 성과가 지속된다면 향후 기업이 성장하고 웹툰산업의 생태계가 보다 다양해 질 가능성이 있다. 정책 측면에서 플랫폼 지원은 아직까지 적극적으로 이루 어지지 못하고 있는 영역이지만, 중소 규모 플랫폼 기업들의 해외진출이 본격화되고 있 음에 따라 이러한 영역의 정책적 관심은 필요한 것으로 보인다.

\section{2. 해외 현지시장 진출에서의 위협점}

\section{가. 낮은 인지도}

웹툰의 잠재력은 높으나 해외에서의 인지도는 아직까지는 낮은 편이다. 최근 들어 웹 툰의 해외 시장 성과에 대한 보도들이 늘어나고 있으나 해외에서의 인지도는 생각보다 는 낮은 편이다. 해외에서는 디지털 만화라는 것이 있었고, 만화가 아닌 대다수의 콘텐 츠들은 세로 스크롤 방식을 취하고 있다. 때문에 웹툰이라는 형식이 한국의 것이라던가 새롭고 혁신적이라는 인식은 생각보다 적은 편이다. 그러나 제작 프로세스 측면에서 볼 때 세로 스크롤 방식은 해외에서 쉽게 따라할 수 있는 형식이 아니다. 만화는 글자 크기, 그림 간 간격 등 여러 가지 요소들이 다 의미를 갖기 때문에 웹툰에서의 배열은 기존의 해외 작가들이 익숙한 방식이 아니다. 또한 올컬러에 빠른 연재 주기 또한 국내의 웹툰 스튜디오화에 따른 고도화의 산물이기에 따라하기에는 어렵다. 이는 겉으로 드라나지 않 는 부분이고 웹툰을 이용하는 고객들에게는 기존의 콘텐츠 이용방식과 부합되는 방식이 라 좋지만, 웹툰을 한국만의 독창적인 것으로 삼고 이를 활용하기에는 불리한 측면이 존재한다. 


\section{나. 현지화 요구}

만화는 지역마다 특색이 다르기에 시장마다 다른 접근법이 필요하다. 최근까지는 국 내에서 성공을 거둔 웹툰IP를 해외에서 유통하면서 성과를 얻고 있지만, 향후에는 현지 의 작가 발굴, 스토리 발굴, 번역, 해외 공동 제작 등의 요소가 중요해 질 수 있다. 이는 국내 시장이 협소하기 때문에 이러한 소비자를 만족시키기 위한 웹툰의 장르가 아직까 지 협소하다는 측면과도 관련된 사항이다. 해외 진출을 원활하게 하기 위해서는 해당 국가의 문화코드나 금기사항 등에 대해 숙지하는 일도 향후에는 중요해질 요소이다. 해 외의 스토리를 발굴하는 작업은 이미 대형 플랫폼사들에 의해 이루어지고 있다. 공동제 작 역시 일부 이루어지고 있는 사항이지만, 해외에서 통할 해외의 스토리를 웹툰으로 제작하는 것에 대해서는 아직까지 경험이 필요할 것으로 보인다. 또한 해외 이용자들의 성향이나 반응 등을 실시간으로 파악하는데 따른 수요도 높아질 것이며 이에 따른 지원 도 필요해질 수 있다. 

웹툰산업 해외진출 진흥 방안 연구

제4장

만화 선도국의 고도화 사례 분석 



\section{제1절 사례분석 개요}

\section{1. 사례분석의 의의}

우리나라 웹툰산업은 다소 독특한 발전 과정을 거치면서 빠르게 발전하였다. 2003년 다음웹툰 과 2004년 네이버웹툰 등 플랫폼이 주도하는 웹툰이 등장하기 이전까지 국내 에서 만화 영역은 산업이라기보다 예술 영역에 더 가까있던 것으로 보인다. 해외 진출 역시 동일한 형태로 이루어졌다. 2010년대부터 윕툰산업의 해외 진출이 모색되었는데 이 역시 대형 플랫폼 주도로 이루어졌다. 2003년도의 다음웹툰의 등장 이후 7년 만에 해외 진출을 시작하였으니 이것 역시 상당히 급진적인 변화이다. 이처럼 우리나라에서는 이미 대부분의 사람들이 웹툰이라는 단어를 특정 플랫폼과 연관지어 연상할 정도이므로 웹툰산업 발전의 히스토리가 당연한 것이지만, 해외에서 볼 때 한국의 웹툰산업은 없던 산업을 새로 만든 것처럼 보이기도 한다.

그러나 여전히 웹툰산업의 해외진출은 도입기 내지 성장기 정도에 불과하다. 해외에 서의 비즈니스 환경은 국내와는 상당히 다르기도 하다. 글로벌 플랫폼과의 경쟁에 대비 해야 하고 새로운 해외 소비자의 성향 파악 등 다양한 과제들이 산적해 있다. 때문에 정책의 역할은 산업의 급격한 발전 이면에 미처 대비하지 못한 부분이 무엇인지 종합적 으로 파악하고, 향후 산업의 고도화 방향을 예측하여 이에 따른 지원을 추진해 나가야 한다.

이를 위해서는 비록 우리나라의 웹툰산업과 발전 과정이 다르지만 산업의 고도화와 해외 진출을 상당히 오랜 기간 이루어져 온 만화선도국의 산업 고도화 과정, 그리고 글 로벌화 전략 등을 함께 고찰해 볼 필요가 있다. 또한 이러한 국가들은 우리나라 웹툰산 업의 주요 경쟁국이면서, 주요 소비시장이기도 하기에 참고할 점이 많을 것이다. 


\section{2. 사례분석의 목적과 대상}

세계적으로 만화산업의 선도국가로 거론되는 것은 일본, 그리고 미국이다. 물론 유럽 국가들에서도 만화 분야가 상당히 발달되어있으나 산업으로서 고도화 과정을 거쳤다고 보기 보다는 예술로서 역사와 전통을 가진다고 볼 수 있다. 일본의 경우 글로벌 만화산 업 규모 1 위의 국가로 이미 1940년대에 망가의 특성으로 대변되는 독특한 표현방식을 제시하였는데 이는 오늘날 세계적인 표준으로 자리매김 하였다. 미국의 경우 글로벌 만 화산업 규모 2 위의 국가이면서, 일찍부터 대량생산을 위한 시스템을 확립했던 경우이다. 그래픽노블이라 불리는 독특한 방식의 만화는 오늘날 IP화를 통한 다양한 영화, 애니메 이션, 게임 등으로 활용되고 있다.

\section{3. 사례분석의 방법과 내용}

시례분석의 방법은 현지 자료 분석 및 현지 사정을 잘 아는 전문가의 협력으로 이루어 졌다. 주요 내용은 해당 국가 만화산업의 고도화 과정, 제작 시스템 및 구조, 유통 시스 템 및 구조, 해외진출 관점에서의 시사점 등으로 구성하여 시사점을 도출하였다.

〈표 4-1〉 고도화 사례분석 개요

\begin{tabular}{c|l}
\hline 구분 & \multicolumn{1}{c}{ 내용 } \\
\hline 목적 & $\begin{array}{l}\text { 만화선도국의 만화산업 고도화 과정과 글로벌적 성공 사례를 분석하여 한국 웹툰 산업의 } \\
\text { 고도화 방향성 모색 }\end{array}$ \\
\hline 분석대상 & 일본 만화산업(글로벌 만화산업 규모 1위), 미국 만화산업(글로벌 만화산업 규모 2위) \\
\hline \multirow{2}{*}{ 방법 } & $\begin{array}{l}\text { 현지 자료 분석 } \\
- \text { 현지 사정을 잘 아는 전문가 인터뷰, 작성 }\end{array}$ \\
\hline \multirow{3}{*}{ 내용 } & - 고도화 과정 확인 \\
& - 제작 시스템 및 구조 파악 \\
& - 유통 시스템 및 구조 파악 \\
& - 해외진출 관점에서의 시사점 \\
\hline
\end{tabular}




\section{제2절 일본 만화산업의 고도화 모델}

\section{1. 고도화 과정}

\section{가. 1946년 1958년: 만화 문법의 확립}

일본만화가 세계적으로 인기를 얻게 된 이유를 크게 두 가지로 정리하면 폭넓은 독자 층의 존재, 그리고 다양하고 풍부한 작품을 들 수 있다. 일본 만화는 출판 만화와 만화 전문 잡지를 기반으로 성장했으며 특유의 연출 기법이 일찍부터 확립되었다. 제한된 지 면 위에서 이야기를 빠르고 쉽게 그리고 재미있게 전달하기 위한 최적의 방법을 찾아낸 것이 일본 만화가 세계의 독자들에게 읽히고 있는 이유이다.

일본 만화의 독특한 스타일, 즉 인물의 표현, 효과선을 활용한 움직임의 연출, 의성어 와 의태어의 시각적 표현, 시공간의 묘사, 칸 나누기 등 특유의 연출 기법을 고도화한 것은 테즈카 오사무(手塚治虫, 1928 1989)이다. 많은 작가가 그에게 영향을 받았다. 테 즈카 오사무는 영화 화면을 지면으로 옮긴 듯한 표현 이른바 영화적 연출을 만화에 도입 했다. 카메라를 통해 피사체를 바라보는 구도와 시점으로 인물과 배경을 묘사했고 클로 즈업, 줌 아웃 등 영화적 기법을 적절하게 배치해 화면을 보다 다채롭게 꾸몄다. 아카홍

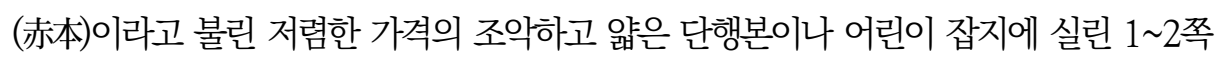
정도의 짧은 옴니버스 만화가 주류였던 시대에 테즈카 오사무의 작품은 혁명이었다. 테 즈카 오사무의 첫 단행본 『신 보물섬(新寶島)』(1947)은 당시 아카홍보다 3배 정도의 분 량에 하드커버로 출판되었고 짜임새 있는 연출과 서사로 큰 인기를 얻었다. 테즈카 오사 무의 등장 이후 어린이 잡지에서 만화의 비율이 늘어났다. 단편이나 옴니버스 만화 중심 에서 점차 장편 연재만화가 늘어나면서 만화는 어린이 잡지의 중심이 된다. 현대 일본 만화의 분기점은 테즈카 오사무이다. 


\section{나. 1959년 1964년: 주간 만화 잡지의 등장}

전쟁 후 사회가 안정을 되찾으면서 어린이 잡지가 복간되거나 창간되었고 이들 잡지 에 연재되는 만화의 분량이 점차 증가한다. 그리고 1959년 『주간 소년 매거진과 『주간 소년 선데이가 창간된다. 이들 잡지가 창간되면서 주간 만화 전문 잡지의 시대가 시작 된다. 주요 출판사는 발행하고 있던 월간 소년, 소녀 잡지를 만화 전문 잡지로 개편했고 1963년 소녀만화 잡지인 『주간 소녀 프렌드』와『주간 마거릿』(두 잡지 모두 현재는 격 주지)이 창간되며 주요 독자층인 10대 어린이를 대상으로 하는 잡지들의 주간지 체제가 확립된다.

아카홍류의 만화 단행본은 소규모 출판사에서 출판되었다. 그러나 대형 출판사에서 어린이 독자를 겨냥한 만화 전문 잡지를 만들면서 만화 출판이 전체 출판시장에서 차지 하는 중요성도 뚜렷해진다. 도로와 철도 교통의 발달로 전국적인 유통망이 구축되었고 대형 출판사의 자금력이 바탕이 된 잡지가 만화뿐 아니라 전체 출판 시장에서 큰 부분을 차지하게 된 것이다.

그리고 이 시기 일본 만화의 발전에 한 가지 중요한 역할을 한 것이 바로 '극화(劇画)'이 다. 극화는 일본 만화가 작품의 다양성과 예술성을 확보하고 성인으로 독자층을 확대하는 계기가 되었다. 이는 일본 만화 시장이 어린이 만화에 편중해 팽창한 것이 아님을 보여준 다. 극화는 1959년 다츠미 요시히로(䣅큼, 1935 2014)가 극화 공방을 만들고 자신의 작품에 어린이용 '만화'와 차별화해 '극화’라는 용어를 만들어 사용하면서 시작되 었다. 다츠미 요시히로는 만화의 영화적 표현을 한 단계 높인 실험적 연출과 묘사를 시도 했다. 다츠미 요시히로와 함께 일련의 작가들은 사회를 날카롭게 풍자하거나 강한 메시지 를 가지고 있는 작품을 창작했고 이러한 작품의 독자층은 어린이가 아니라 성인이었다.

1964 년에는 만화 잡지 『가로(ガロ)』가 창간되어 실험적이고 개성 있는 작가주의적 작품들이 연재되었고 재능있는 신인의 발굴에도 큰 역할을 했다. 이후 ${ }^{\circledR} \mathrm{COM}$ 이 창간되 면서 두 잡지 모두 전공투 세대의 대학생들에게 높은 인기를 얻었다. 이처럼 만화 독자 의 연령이 상향되고 어른들이 보고 즐길 수 있는 만화가 많아지자 만화를 비평의 대상으 로 보기 시작한다. 그리고 만화가 어린이의 오락거리가 아닌 출판물이자 독서의 대상이 될 수 있다는 인식의 전환도 일어나게 된다. 일본 만화산업의 발전은 만화에 대한 인식 의 변화와 폭넓은 독자층을 바탕으로 한다. 


\section{다. 1965 1974: 단행본 체제의 확립}

이 무렵 만화 단행본의 양이 증가하면서 신간 만화를 따로 모은 서가를 설치하는 서점 이 많아진다. 만화책을 서점에서 자연스럽게 구매하고 소비하는 문화가 정착된 것이다. 그리고 1967년 『주간 소년 점프』(이하『소년 점프』)가 창간된다. 점차 만화 잡지의 중요 성이 강화되고 있던 시점이다. 1966년 『주간 소년 매거진 이 발행 부수 100 만 부를 돌 파했고 1970년에는 150 만 부까지 그 양이 증가한다. 『주간 소년 매거진』, 『주간 소년 선데이』, 『주간 소년 챔피언』, 『주간 소년 킹』, 『소년 점프』등 주요 소년만화 잡지는 서로 경쟁하면서 만화시장을 확장하는 역할을 했다. 잡지들 사이의 경쟁이 심화 되었지 만, 어느 한 잡지가 사라지는 것이 아니라 모든 소년만화 잡지의 발행 부수가 전반적으 로 증가한다. 발행 부수가 증가한 첫 번째 요인은 독자층의 확대, 두 번째는 편집부의 역할 변화로 볼 수 있다. 독자층이 확대된 것은 꾸준히 다양한 스펙트럼의 작품이 창작 되고 그러한 만화를 손쉽게 접할 수 있는 환경이 조성된 데에 있다. 그리고 잡지 편집부 의 역할 변화를 가장 명확하게 보여주는 것이 『소년 점프』에 의한 편집 체제의 혁신이 다. 실력 있는 편집자를 육성하고 신인 작가를 발굴하는 편집부의 역할이 확대되고 강화 되었다. 체계적이고 전략적으로 잡지를 만들고 독자의 요구를 작품과 잡지에 반영하면서 독자가 원하는 작품이 다량으로 생산되었다. 만화는 작가 혼자만의 힘으로는 만들 수 없는 것이다.

\section{라. 1975년 1984년: 만화시장의 다양성 강화}

잡지와 단행본 출판 체제가 완성된 이후 만화 시장의 다양성이 강화된다. 1975년 시 작된 만화 동인지 판매전인 '코믹 마켓’ 은 상업 출판 이외의 새로운 만화 시장의 가능성 을 보여주었다. 만화의 창작과 소비, 유통이 프로 작가와 전문 출판사의 상업적 영역뿐 아니라 아마추어 독자들에게까지 열린 것이다. '코믹 마켓'은 독자들이 자발적으로 만든 행사로 기업이나 국가의 후원 없이 동호회의 참가회비와 행사 카탈로그 판매수익으로 운영되며 '코믹 마켓 준비회'가 주최한다. 1975년 개최된 첫 코믹 마켓은 32개 동호회 와 700명이 참가한 소규모 행사였지만 1986년 참가자 수는 3만5천 명으로 1990년에는 25 만 명으로 늘어난다. 2000년 이후 참가자 수는 50만 명 이상으로 증가해 세계 최대규 모의 만화 이벤트가 되었다. 매년 여름과 겨울 두 차례 3일간 개최되었고 2019년부터는 
개최일이 4일로 늘어나면서 참가자 수가 역대 최대인 73 만 명을 기록했다. 그러나 코로 나19로 인해 2020년 이후 행사는 중지된 상태이다. 만화 동호회에서 만든 동인지를 판 매하는 행사이지만, 이는 스스로 만화를 창작하고 다른 독자들과 교류하며 만화를 매우 적극적으로 향유하는 계층이 존재한다는 것을 증명했다. '코믹 마켓'과 유사한 동인지 판매행사는 다양한 규모로 일본 각지에서 열리고 있다. '코믹 마켓'의 경제적 효과도 적 지 않다. 언론에서는 '코믹 마켓'의 경제효과를 100억 엔 이상으로 추산한다. '코믹 마켓 준비회' 가 공개한 설문 자료에 의하면 ‘코믹 마켓’ 참가자의 연령은 20 대가 $45 \%, 30$ 대 가 $30 \%$ 이고 이벤트 회장에서 동인지와 관련 상품을 구매하는 데 사용하는 금액은 만엔 이상 3만엔 미만이라는 응답이 가장 많았다. 만화와 만화 문화를 적극적으로 즐기는 독 자의 존재는 일본의 만화산업이 지속성을 가지고 발전할 수 있는 요인의 하나이다.

\section{마. 1985년 1994년: 만화 시장의 성장}

이 시기는 만화와 애니메이션, 게임 등 서브컬쳐에 대한 국민의 관심이 높아진 시기이 다. '코믹 마켓'의 참가자가 1986년 3만 5천 명에서 불과 4년 만인 1990년 25만 명으로 증가한 것에서 볼 수 있듯 20 30대 독자를 중심으로 만화를 즐기는 문화가 매우 자연스 럽게 퍼져있었다. 이러한 사회적 변화를 반영하듯 만화 잡지의 판매량도 대폭 증가한다. 『소년 점프』의 발행 부수가 1985년 400만 부를 돌파했고 1988년에는 500만 부를 돌파 한다. 그리고 1992년에는 잡지 역사상 최고 발행 부수인 653만 부를 기록한다. 만화의 판매량 증가로 만화가 일본의 출판시장 전체에서 차지하는 비율도 높아진다. 만화 잡지와 단행본을 합해 전체 출판시장에서 차지하는 비율이 1991 년 이후 $35 \%$ 이상으로 높아졌 다. 출판시장의 3 분의 1 을 만화가 차지하게 된 것이다. 버블경제의 붕괴로 1993 년 무렵 부터 경제침체가 심화한다. 잡지의 광고 수입이 줄어들면서 각 출판사의 만화에 대한 의 존도가 높아진다. 만화 잡지를 발행하지 않던 출판사들은 기존 대형 출판사가 발행하지 않는 장르의 만화 잡지를 창간한다. 게임계 만화 잡지가 창간되었고 주로 동인지로 유통 되던 $\mathrm{BL}$ (Boys' Love, 남성 동성애를 다룬 장르)을 전문으로 하는 상업잡지가 창간된다. 시장이 포화 상태에 이른 후 장르를 다양화해 새로운 시장을 개척한 것이다. 


\section{바. 1995년 이후: 시장의 정점과 쇠퇴}

출판과학연구소의 통계에 따르면 1995 년 만화 판매 추정액은 잡지 3,357억 엔 단행 본 2,507 억 엔으로 총 5,864 억 엔을 기록했다. 만화 판매액은 1995 년을 정점으로 서서 히 줄었다가 2014년 이후 반등을 시작한다. 출산율의 저하로 만화의 주 소비층인 10대 인구가 서서히 줄어든 것도 만화 시장의 축소와 연관이 있다. 그러나 2014년 디지털 코 믹스의 판매량이 의미 있는 숫자를 보여주면서 전체 만화 판매액이 증가한 것이다. 1995 년을 정점으로 지속적으로 감소하던 만화 판매액은 2020년 1995 년의 기록을 깨 고 최고액을 기록한다. 2020년 만화 판매액이 큰 폭으로 상승한 것은 코로나19의 여파 로 활동에 제약이 생기면서 실내나 집에서 보내는 시간이 길어지고 만화의 소비량이 늘 어났기 때문으로 보인다. 출판과학연구소는 2020년 만화 판매액을 단행본 2,079억 엔, 잡지 627억 엔. 디지털 코믹스 3,420억 엔으로 추산한다. 일본의 디지털 코믹스는 한국 과 같은 웹툰 플랫폼뿐 아니라 기존의 종이 출판 만화를 디지털화해 서비스하거나 현재 발행 중인 잡지를 종이 출판과 동시에 형태만 디지털화해 발매하는 경우도 포함한다. 웹툰 플랫폼의 시장 점유율은 아직 높지 않다. 만화 판매량의 지속적인 감소가 멈춘 원 인은 디지털 코믹스 판매량의 증가에 있다. 디지털 코믹스가 기존 시장을 나눠 가진 것 이 아니라 새로운 수요를 창출한 것이다.

\section{2. 제작 시스템 및 구조}

일본에서 가장 인기 있는 만화 잡지는 「원피스」, 「귀멸의 칼날」 등이 연재된 『소년 점프』이다. 『소년 점프』는 1968 년 창간되었는데 주요 소년만화 잡지인 『주간 소년 매거 진』과 『주간 소년 선데이』보다 10 년 가까이 늦은 출발이었다. 『소년 점프』는 후발주자 임에도 경쟁에서 우위를 차지했고 오랫동안 최고 인기 잡지의 자리를 지키고 있다. 『소 녀 점프』의 편집방침과 전략은 일본의 만화 출판에서도 성공 사례로 꼽히고 있다. 일본 만화 제작의 중심은 잡지에 있다. 그리고 그 잡지에 연재된 만화는 단행본으로 출판되어 다시 한번 더 독자들을 찾는다. 일본의 잡지 제작 시스템 일부는 한국의 웹툰 플랫폼에 도 적용 가능한 사례가 될 것이다. 
[그림 4-1] 일본 만화 시장 구조와 규모

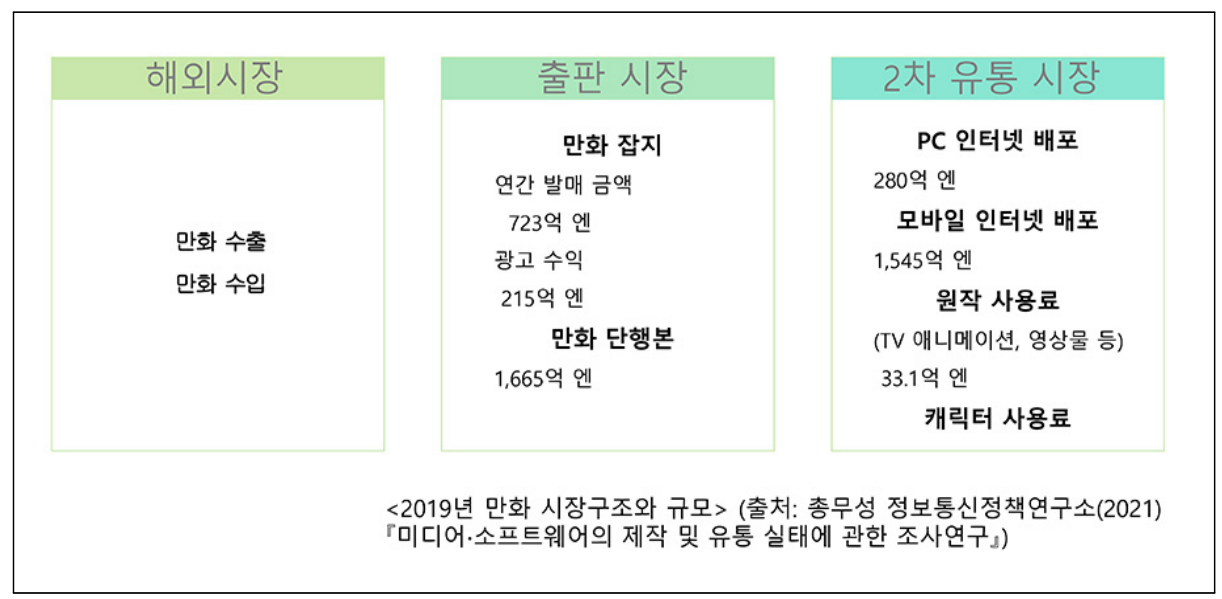

\section{가. 철저한 만화 중심의 잡지 편집}

『소년 점프』가 창간된 1968 년의 만화 잡지는 전체 분량의 4분의 1 정도를 기사나 소설과 같은 읽을거리가 차지하고 있었다. 『소년 점프』는 과감하게 지면 전체를 만화로 채우는 편집을 시도한다. 만화를 읽는 것은 어린이 독자들이지만 그 만화책을 사는 것은 어른들이었던 당시로써는 매우 파격적인 잡지 구성이었다. 만화 잡지를 표방한다고 해도 기사와 문학에 최소한의 지면을 할애하고 있었던 것은 어린이를 대상으로 하는 교양 잡 지의 전통 때문이다. 그러나『소년 점프』는 철저하게 만화에 집중한다. 창간 이후 다양 한 파격을 시도했고 이러한 시도는 현재 일본 만화 잡지의 편집과 제작 시스템의 기본이 되어 지금까지 이어오고 있다.

\section{나. 미디어 믹스의 적극적인 시도}

일본의 인기 만화, 특히 소년 잡지에 연재된 작품은 애니메이션으로 제작되는 비율이 매우 높다. 잡지에 연재된 작품이 단행본으로 출판되고 TV 애니메이션으로 제작되며 때 로는 드라마나 영화로 만들어지고 게임으로 제작되기도 한다. 일본에서는 1960년대부 터 현재까지 만화 원작을 활용한 TV 애니메이션과 드라마 제작이 활발하게 진행되고 있다. 이는 수익을 극대화한다는 측면에서 출판사와 창작자 모두에게 매우 긍정적이다. 연재가 진행 중인 작품이 TV 애니메이션이나 드라마로 소개되면 자연스러운 광고 효과 
로 원작 만화의 판매량이 증가한다. 특히 『소년 점프』는 창간 초기부터 TV 애니메이션 사업에 적극적이었다. 연재만화의 TV 애니메이션화는 광고 효과와 함께 캐릭터 상품의 개발로 확대되기 쉽고 이러한 2차 저작의 저작권료는 작가에게 큰 수익이 된다. 단행본 인세나 미디어 믹스를 통해 얻는 저작권 수익은 작품 연재 시 발생하는 원고료 수익과 비교할 수 없이 크다. 따라서 미디어 믹스에 적극적인 출판사는 작가들이 선호하는 연재 처가 된다. 일본의 영화 흥행 역대 1 위는 ${ }^{『}$ 소년 점프』에 연재된 만화 「귀멸의 칼날」을 원작으로 한 극장판 애니메이션 〈귀멸의 칼날 - 무한열차 편〉이다. 2 위는 지브리의 〈센 과 치히로의 행방불명〉이다. 3위가 영화 〈타이타닉>이고 4위는 디즈니의 애니메이션 〈겨울 왕국〉이다. 이밖에도 5위 〈너의 이름은. 7 위 〈모노노케 히메〉, 8위 〈하울의 움 직이는 성〉, 12 위〈벼랑 위의 포뇨〉, 13 위 〈날씨의 아이〉 등 극장용으로 제작된 애니메 이션이 상위권에 올라있다. 애니메이션을 나이와 관계없이 누구나 자연스럽게 관람하는 문화가 없으면 나오기 힘든 흥행성적이다. 좋은 흥행성적을 거둔 애니메이션이 많고 흥 행 랭킹에는 만화를 원작으로 제작된 실사 영화도 적지 않다. 이들 실사 영화는 대부분 먼저 TV 드라마로 제작된 후에 극장판이 제작된다. 만화를 원작으로 매우 폭넓은 미디 어 믹스가 시도되고 원작이 인기 있는 작품이면 많은 경우 흥행에 실패하지는 않는다. 만화만으로는 얻을 수 없는 국민적인 인기와 화제성은 미디어 믹스를 통해 얻어지고 애 니메이션이나 영화의 인기는 다시 원작 만화에 관한 관심으로 이어진다.

\section{다. 적극적인 신인 발굴과 전속 작가 제도}

『소년 점프』는 후발주자로 기존 인기 작가의 영입이 쉽지 않았다. 『소년 점프』편집부 에서 신인 작가 발굴에 더 큰 관심을 두게 된 이유이다. 『소년 점프』는 소년만화 잡지 최초로 신인 만화상을 신설하고 공모전을 실시했다. 파격적인 금액의 상금으로 큰 반향 을 불러일으키기도 했다. 그리고 이렇게 실시한 공모전에서 선발된 신인 작가들의 작품 을 독자들에게 선보일 수 있는 지면도 만들었다. 『소년 점프』는 정기적으로 발매되는 잡지 이외에 신인 작가들의 작품을 게재한『점프 GIGA』라는 제목의 증간호를 계간으로 발행하고 있다. 증간호는 신인 공모전에 입상한 작품과 신인 작가의 작품을 중심으로 구성된다. 증간호에서 좋은 반응을 얻은 작가는 ${ }^{\circledR}$ 소년 점프』에서 정식 연재의 기회를 얻게 된다. 공모전 입상이 곧 프로 데뷔의 의미는 아니다. 
편집부를 직접 찾아온 작가 지망생의 작품 중에서 눈에 띄는 작품을 선별해 내는 것도 편집자의 역할이다. 『소년 점프』의 경우 하루 평균 20 명 정도가 편집부를 찾아오고 1 층 로비에 이들과 편집자가 만나는 부스가 따로 설치되어있다. 이들 중에 선별된 만화가 지 망생이 정식 연재 전에 활동하는 무대가 증간호이다. 편집부는 기성 작가를 스카우트하는 것보다 아직 알려지지 않은 좋은 신인을 발굴하는 것에 집중한다. 『소년 점프』를 통해 데뷔한 신인이 전속으로 점프에서만 작품을 연재하는 규칙은 지금까지 이어오고 있다.

일본의 만화 편집자는 약 2,000 명 정도로 추산된다. 편집자 한 명이 담당하는 만화가 는 정식으로 작품을 연재하고 있는 작가는 1 2명, 연재를 준비하고 있는 작가가 5명 정도, 그리고 만화가 지망생 20 명 정도이다. ${ }^{\circledR}$ 소년 점프』의 편집부는 편집장 1 명, 부편 집장 3 명, 편집자 17 명 그리고 만화 앱 서비스인 '점프 플러스'의 편집장 1 명, 부편집장 1 명, 편집자 7 명, 총 30 명으로 구성되어 있다. 편집자는 연재 중인 작가의 작품을 관리 하고 작품 창작을 위해 협력하기도 하지만, 작가 지망생을 훈련 시키는 것도 매우 중요 한 업무의 하나이다. 일정 기간의 훈련을 통해 실패 부담을 줄이는 동시에 작가의 능력 을 미리 테스트하는 것이다. 독자 수 만큼이나 많은 작가 지망생이 존재하는 일본에서 프로 작가로서 살아남기 위한 경쟁은 정식 연재 전에 이미 시작된다.

\section{라. 편집자 육성}

신인 발굴과 함께 일본의 제작 시스템에서 중요시하는 것이 편집자의 육성이다. 편집 부에 신입으로 입사한 후 선배 편집자들로부터 여러 훈련을 거치며 체계적으로 단계를 밟아 올라간다. 인기 작품이 탄생하기까지 작가는 물론 편집자의 역할도 매우 중요하다. 작가가 안정적으로 작품을 창작할 수 있도록 다양한 지원을 해야 하는 것은 물론 창작 과정에서도 중요한 역할을 한다. 작품을 위한 자료 조사와 사전 조사에서부터 작품의 방향성에 대해 적극적으로 의견을 내거나 아이디어를 제공하는 등 편집자가 창작에 많 은 영향을 줄 수 있는 시스템이다. 재능 있는 작가도 중요하지만, 그 재능을 창작에 집중 하게 하고 능력 이상으로 재능을 펼칠 수 있도록 돕는 것이 바로 편집자의 역할이다. 편집자가 신인을 발굴해 육성하고 작가와 함께 성장하는 것이 일본 만화 제작 시스템의 특징이자 강점이라고 할 수 있다. 작가의 능력에만 의존해서는 좋은 작품이 지속적으로 나오기 힘들고 작품의 재미가 유지되기도 어렵다. 


\section{마. 독자의견의 분석과 반영}

일본 만화 잡지 대부분은 독자들의 설문을 취합하고 실제 편집에 반영하고 있다. 잡지 에 애독자 엽서를 첨부하는 전통적인 방식을 활용했고 최근 애플리케이션을 기반으로 발행되는 잡지는 더욱 간단한 방법으로 애독자 설문을 시행한다. 『소년 점프』의 경우 독자 인기투표를 집계해 작품 구성에 반영하는 이른바 '앙케트 지상주의'로 유명하다. 이에 대한 비판도 있으나 독자들의 요구와 관심사, 최신 유행이 빠르게 작품에 반영되는 장점이 있다. 매주 10,000 통 정도의 엽서를 받고 이중 무작위로 1,000 통 정도를 선별해 분석한다. 인기투표 분석을 통해 지속적으로 인기 하위권에 포함되는 작품은 독자들의 의견을 반영해 스토리를 변경하기도 한다. 그러나 작품의 인기가 오르지 않는 경우 10 주 정도의 기간을 주고 작품을 마무리 짓도록 하고 연재 종료에 이른다. 일본의 만화계는 독자의 의견이 적극적으로 반영되는 무한 경쟁의 무대이기도 하다. 재미있는 만화가 살 아남는 구조이다. 다수의 의견으로 선택된 인기 만화는 보편적인 재미와 대중적인 선호 도를 확보한 경우가 많다. 일본 만화가 일본 국내뿐 아니라 해외에서도 많은 독자에게 읽히는 비결은 이렇게 대중적 취향을 작품의 창작에 직접 반영하는 제작 과정에 있다.

\section{3. 유통 시스템 및 구조}

[그림 4-2] 일본 서적 유통 시스템

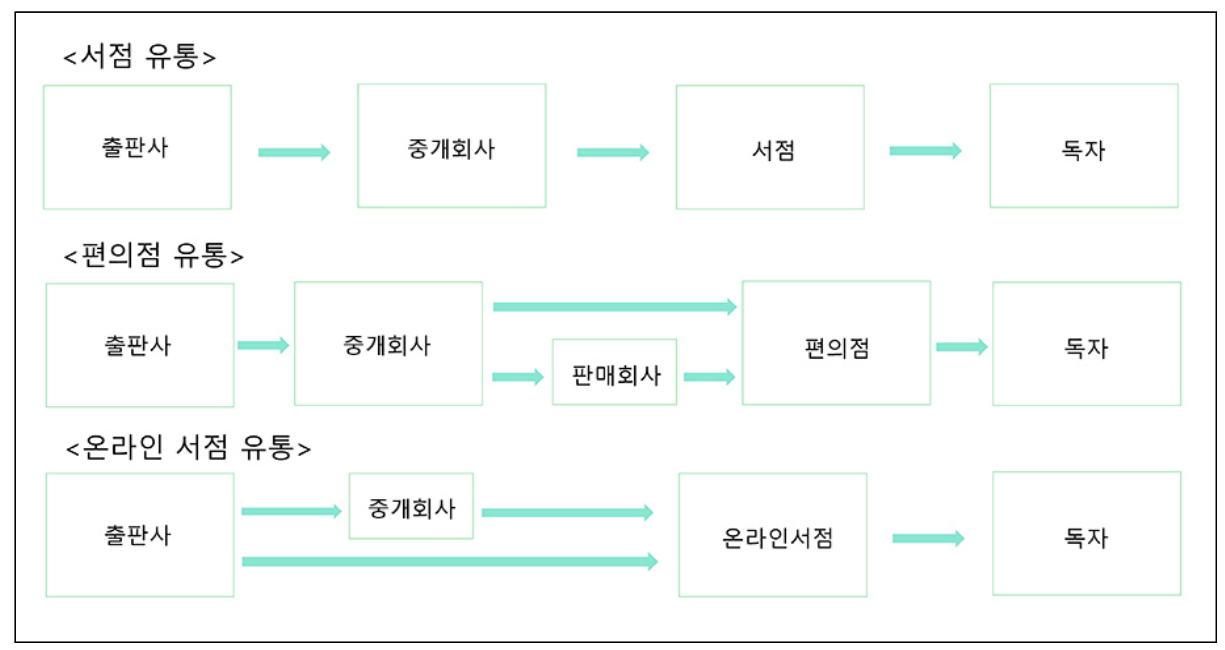




\section{가. 일본 출판 유통의 특징}

일본 출판 유통의 특징은 우선 위탁판매제도에 의해 신간 서적이 유통된다는 점, 두 번째 '재판(再版)제도'로 정가판매가 일반적이라는 점, 세 번째는 토리츠기(取次)라고 불 리는 서적 중개회사가 유통의 중심 역할을 하고 있다는 점이다. 일본에는 2020년 기준 3,102 개의 출판사와 11,024 개의 서점이 있다. 이들 출판사와 서점을 연결하는 것이 소 수의 중개회사이다. 위탁판매제도는 출판사와 중개회사(토리츠기) 그리고 서점의 삼자 계약에 기반해 정해진 기간 내에 팔고 남은 재고를 서점이 반품할 수 있도록 하는 출판 물 판매 방법이다. 위탁제도의 장점으로 서점은 재고에 대한 부담 없이 서적을 매입할 수 있고 다양한 출판물을 적극적으로 진열할 수 있다는 점이 있다. 그리고 출판사는 많 은 서점에 책을 진열하고 선전할 수 있다는 장점이 있다. 그러나 한편으로 반품의 증가 가 출판사에 부담을 준다는 지적도 있다. 출판업계의 불황도 오랫동안 이어지고 있어 출판업계는 위탁판매제도를 이용하면서도 책임판매제의 도입과 서점으로부터의 발주 후 배본(配本)으로의 전환 등을 추진하고 있다.

재판(再版)제도의 정식 명칭은 '재판매가격 유지제도'로 출판사가 서적, 잡지의 정가 를 정하고 서점에서 정가로 판매하도록 하는 제도로 출판사와 중개회사(토리츠기), 중개 회사(토리츠기)와 서점 사이에 계약이 이루어진다. 독점금지법에서는 재판매가격의 구속 을 금하고 있지만, 출판물에 관해서는 법의 개정으로 예외적용이 인정되었다. 독자는 전 국 어디에서든 같은 가격으로 서적을 구매할 수 있지만, 규제 완화와 자유로운 경쟁의 관점에서 이 제도에 대해 재고해야 한다는 공정거래위원회의 의견이 있어 제도의 유지 와 운용방법에 관한 논의가 이루어지고 있다.

일본에서는 연간 8 만 종 정도의 신간 서적이 발행되고 있고 잡지는 2,700 종 이상이 간행되고 있으며 출판 유통은 다품종 소량생산방식을 취하고 있다. 이 중 만화 단행본은 2019 년 기준 신간 12,805 종, 잡지는 194 종으로 집계된다. 일본 출판의 특징으로 잡지 의 종류가 매우 다양하고 발행되는 양도 많다는 점을 들 수 있다. 다양한 잡지 출판이 잡지유통과 서적유통을 결합해 서적의 단가를 낮췄다는 분석도 있다. 일본 이외의 국가 는 서적과 잡지유통이 별개의 경로를 갖는 경우가 많다. 그러나 일본은 발행 부수가 적 고 판매 기간이 긴 서적 유통을 정기적으로 대량 발행되는 잡지유통과 결합해 유통 단가 를 낮춘 결과 서적 가격이 저렴해질 수 있었다는 것이다. 


\section{나. 일본의 만화 유통 시스템 사례}

\section{1) 편의점 유통}

일본에서 만화 유통의 한 축을 담당하는 것이 편의점이다. 전체 만화의 $65 \%$ 정도가 서점에서 유통되고 있으며 20\%가 편의점, 기타 유통 채널이 $15 \%$ 로 추산된다. 2021년 1 월 일본의 편의점 수는 약 5 만7천 개 정도이다. 2020년 집계된 전국의 서점 수가 11,024 개인 것과 비교하면 다섯 배가 넘는 숫자이다. 편의점에서 잡지를 취급하는 것은 일반적이다. 만화 잡지의 경우 주로 남성 독자를 대상으로 하는 잡지가 편의점에서 유통 된다. 그리고 편의점 유통을 목적으로 제작되는 단행본 레이블이 별도로 존재한다. 1999 년 쇼가쿠칸에서 편의점에 유통할 목적으로 단행본 레이블을 만들었고 이후 고단샤, 슈에 이샤를 포함해 만화를 발행하는 대부분의 출판사가 편의점에 만화 단행본을 유통하고 있 다. 무엇보다 편의점에서 판매되는 만화 단행본은 저렴한 가격을 특징으로 한다. 편의점 의 주력 상품인 도시락 등 다른 상품과 함께 구입해도 크게 부담이 되지 않는 염가판으로 제작된다. 서점에서 판매되는 단행본과 달리 제작단가를 낮추기 위해 페이퍼백으로 제작 되고 저렴한 종이를 사용하며 일반적인 만화 단행본과 달리 책 커버가 없는 형태로 제작 된다. 사이즈는 $\mathrm{B} 6$ 를 기본으로 $\mathrm{A} 5$ 에서 문고판으로 나오는 경우도 있다. 현재 연재 중인 작품이 아니라 과거 만화 잡지에 연재되었던 작품을 출간한다. 편의점의 만화 단행본은 신작 위주로 진열되는 서점과 다른 상품을 취급하며 저렴한 가격을 특징으로 한다.

\section{2) 신고서점(新古書店)}

비교적 최근 출판된 책이지만 중고 책 즉, 신고본(新古本)을 취급하는 신고서점에서 유통되는 만화의 양도 적지 않다. 전국 규모의 체인점으로 운영되는 Book off가 대표적 인 신고서점이다. 이들 신고서점의 주력 상품은 만화책이고 문고판 서적, $\mathrm{CD}, \mathrm{DVD}$, 게 임 소표트웨어도 함께 취급한다. 희소한 중고 서적보다는 대중적인 인기를 얻은 만화책 과 대량 출판되는 문고판 서적을 주로 취급한다. 신간의 경우 정가와 크게 차이가 나지 않지만 발행되고 시간이 흐른 단행본은 100 엔의 균일가에 판매되기도 한다. 신간은 고 객들로부터 매입해 재판매 하기때문에 신고서점에서 유통되는 신간은 매우 적다. 신고서 점의 경우 대형 점포가 많고 유동인구가 많은 곳에 주로 위치한다. 점포 수가 가장 많은 Book off의 경우 2020년 기준 전국에 801개의 점포가 있다. Book off의 주요 주주 
중에 고단샤와 슈에이샤, 쇼가쿠칸 등 출판 3사가 포함되어 각각 $4.05 \%$ 의 지분을 가지 고 있다는 점도 흥미롭다.

\section{3) 다양한 판형의 단행본}

일본 만화 출판의 특징 중 하나는 같은 작품을 다양한 형태의 책으로 출판한다는 것이 다. 잡지에 연재 중인 작품이 처음 단행본으로 만들어질 때는 보통 신서판(新書制, 106 $\mathrm{mm} \times 173 \mathrm{~mm}$ )으로 발행된다. 이후 책 크기를 좀 더 확대한 애장판(A5, B5)으로 나오는 경 우도 있고, 작품에 따라서는 문고판(AG)이 있는 경우도 있다. 편의점에서 유통되는 염가 판은 보통 B6 사이즈와 A5 사이즈로 제작된다. 단행본의 발매 주기는 주간 잡지에 연재 되는 경우 3 개월에 한 권 정도, 1 년에 3 4권의 단행본이 출간되고 월간지 연재의 경우 6 개월에 한 권, 1 년에 두 권 정도가 발행된다.

만화 단행본이 본격적으로 제작, 판매되기 시작한 것은 1960 년대 후반부터이다. 1966년 코다마프레스사에서 '코다마다이아몬드 코믹스'를 발매했다. 이전까지 만화를 어린이용으로 취급하던 편견이 조금씩 사라지고 극화를 중심으로 성인층으로 독자가 확 대되던 시기였다. 만화를 단행본으로 소비할 수 있는 구매력을 가진 연령대의 독자들이 대두된 것이다. 단행본의 가능성이 증명되자 주요 출판사에서 잡지에 연재되는 작품을 단행본으로 출간하기 시작한다. 1967년 고단샤는 '고단샤 코믹스'를 발행했는데 고단샤 의 인기 소년만화 잡지인 『주간 소년 매거진』에 연재된 작품을 전문으로 하는 레이블로 기획되었다. 잡지에 연재된 인기 만화를 묶은 단행본 출판이 본격적으로 시작된 것이다. 고단샤 코믹스가 성공할 수 있었던 이유는 단행본의 유통 방법을 변경한 데에 있다. 그 이전까지 만화 단행본은 서적으로 분류되어 유통되었다. 서적을 취급할 수 있는 서점에 서만 만화 단행본이 유통되었으나 고단샤 코믹스는 서적이 아닌 잡지로 유통 채널을 선 택한다. 고단샤 코믹스가 잡지와 같은 루트로 유통되면서 기존의 서점 유통에 더해 단행 본을 취급하지 않는 잡지 가판대나 매점, 소규모 잡지 전문 서점 등에도 만화를 유통할 수 있었고 발행 부수가 비약적으로 늘어난다. 정기적으로 정해진 날짜나 요일에 유통해 야 하는 잡지와 함께 단행본을 유통할 경우 그 비용 절감효과가 있어 만화 단행본은 출 판 산업에서 잡지의 일부로 유통되는 시스템이 정착했다. 일본의 만화 잡지는 독자의 성별과 연령(어린이, 소년/소녀, 청년, 성인 등), 발행주기(주간, 격주, 월간, 격월간, 계 
간) 등으로 세분되어 있고, 호러, 판타지, 추리 등 특정 장르의 작품만을 다루는 잡지까 지 매우 폭넓고 다양하게 만들어지고 있다. 그에 더해 하나의 작품이 여러 가지 단행본 형태로 중복해서 만들어진다. 독자들의 선택지가 매우 넓을 뿐 아니라 특정 작품이나 작가의 팬이라면 같은 작품을 중복해서 구매하게 된다.

\section{4. 해외진출 관점에서의 시사점}

\section{가. 열려있지만 견고한 벽}

일본의 만화시장은 여러 가지 특수성을 고려해야 한다. 전 세계 어느 지역의 만화시장 보다 거대하며 매우 탄탄한 독자층과 제작·유통 시스템을 갖추고 있다. 만화가를 꿈꾸는 만화가 지망생도 많고 공모전 입상 등을 통해 작품 연재를 준비하고 있는 미래의 만화가 도 많다. 독자의 나이, 성별, 작품의 주제 등으로 촘촘히 세분화한 200종 가까운 만화 잡지의 수가 말해주듯 일본만화는 폭넓은 독자층과 다채로운 작품을 기반으로 구축되어 있다. 외국의 문화콘텐츠를 소비하고 즐기는 것에 대한 규제나 심리적 저항도 적다. 재 미있고 새로운 작품을 찾는 독자들이 있는 열린 시장이지만, 오랫동안 구축된 만화시장 과 제작 시스템은 오히려 일본 진출에 장애물로 작용할 수 있다. 일본 독자들은 일본식 만화 문법에 매우 익숙하며 혁신이나 새로운 변화를 부담스러워하는 사회적 분위기도 있다. 일본 특유의 기술과 체제가 고도로 발달하면서 오히려 역동성을 상실하고 새로운 흐름을 외면한 채 고립되는 시례를 대중음악이나 영화, 드라마 등의 문화 분야에서도 볼 수 있다. 특히 일본의 독자들은 외국만화에 큰 관심을 두지 않는 것이 현실이다. 해외 작품이 번역되어 소개되는 양도 극히 적다. DC와 마블 출판사에서 발행한 미국 만화와 프랑스 만화, 한국 만화 등 외국만화의 번역판 단행본은 연간 200권을 넘지 않는다. 일 본 만화시장의 규모를 생각하면 매우 적은 숫자이다. 단순히 작품을 번역해서 소개하는 것만으로는 일본 만화시장의 견고한 벽을 넘기 어렵다.

\section{나. 한국만화의 일본 진출 사례}

2001년 한국의 만화출판사 대명종은 일본에 타이거 북스 라는 현지 법인을 만들고 
김동화의 〈기생 이야기〉, 원수연의 〈풀 하우스〉, 김혜린의 〈비천무〉, 한승원의 〈그대의 연인〉, 양영순의 〈누들 누드〉, 박희정의 〈호텔 아프리카〉, 박산하의 〈울트라 붐붐〉, 허영 만의 〈세일즈 맨〉 등 8 작품을 번역, 출판했다. 작품 전권을 순차적으로 발행할 예정이 었지만 판매 부진으로 결국 예정대로 발행되지 못했다. 다양한 장르와 시기의 작품으로 일본 시장 진출 가능성을 타진하기 위한 기획이었지만 일본 독자의 취향이나 시장 분석 과 홍보 전략도 부족했고 번역의 질도 높지 않았다. 결과는 실패였다.

실패 사례만 있는 것은 아니다. 의미 있는 성과를 보여준 사례도 있다. 박소희의 〈궁〉 이 2012년 출간되었고 작가의 사인회가 열리기도 했다. 드라마 〈궁〉이 인기리에 방영된 결과이다. 윤태호의 〈미생〉은 2017년 문화청 미디어 예술제 만화부문 우수상을 받았다. 일본의 주요 만화상 시상식에서 한국 만화가 상을 받은 첫 시례이다. 〈미생〉을 원작으로 한 동명의 드라마가 일본에서 방영되었고 2016년에는 후지 TV에서 리메이크되는 등 좋은 평가를 받았다. 작품의 서사가 일본 독자들도 충분히 공감할 수 있는 내용이었고 무엇보다 작품 자체의 완성도가 높았다. 이들 작품이 독자들의 관심을 받은 배경에는 원작 드라마의 인기가 있다. 드라마나 애니메이션이 방영되면 원작 만화의 판매량이 증 가하는 효과가 있다. 일본에는 만화를 원작으로 하는 TV 드라마가 상당히 많다. 한국 만화에 대한 정보가 부족한 현실에서 드라마로 인기를 얻은 작품의 원작에 관한 관심은 자연스러운 것이다. 지상파 TV 드라마뿐 아니라 넷플릭스를 통해 방영되는 한국 드라마 에 대한 관심이 높아지고 있고 웹툰을 원작으로 제작된 드라마가 인기를 얻는 사례도 늘고 있어 드라마 원작 만화와 웹툰에 대한 관심은 자연스러운 것이다.

일본에 진출한 한국기업의 웹툰 플랫폼에 연재되는 한국 웹툰에 대해 고단샤의 국제 저작권 관리부의 관계자는 고단샤의 만화 포털사이트인 '고단샤 코믹 플러스'의 기사에 서 “일본 만화의 퀼리티가 높아서 절대 질 리 없다」고 하는 사람도 있지만, 디지털에 한해서는 확신할 수 없” 으며 “실제로 아시아에서 어느 정도 성공을 거두고 있다"고 평가 한다. 그리고 웹툰이 동남아시아뿐 아니라 북미지역 등에도 진출하고 있으며 이에 대해 안이하게 생각하다가는 어느 순간 한국의 웹툰이 일본 이외의 전 세계를 석권할 수도 있다고 말한다. 그리고 일본 이외의 국가의 독자가 웹툰의 새로운 만화 문법-컬러, 세로 스크롤-을 당연한 것으로 받아들이게 되고 흑백의 페이지 만화인 일본 만화 자체를 이질 적인 것으로 느끼게 되는 상황을 우려한다. 일본의 일부 전문가는 K-POP과 한류 드라 마의 글로벌 지향적인 전략의 연장선에서 웹툰을 바라보고 있다. 


\section{제3절 미국 만화산업의 고도화 모델}

\section{1. 고도화 과정}

\section{가. 미국 만화산업의 시기별 구분}

미국 만화산업은 1934년 이스턴 컬러(Estern Color) 출판사가 페이머스 퍼니스 (Famous Funnies) 1호 잡지를 출간하면서 시작했다.49) 물론 당시 코믹북(Comic book) 은 신문에 이미 연재된 코믹 스트립스(Comic strips)중 매월 엄선하여 재발행한 묶음집의 형태였다. 그러나 이후 슈퍼맨의 대성공처럼50) 신문에 볼 수 없던 새로운 스토리가 실리면 서 인쇄 만화시장은 하나의 산업으로서 자리매김한다. 이후 거의 한 세기에 걸쳐 발전해온 미국 만화산업은 여러 번의 변화를 거듭하며 부정적인 전망에도 불구하고 여전히 견고한 시장을 형성하고 있다. 북미 만화시장은 2019년 전년 대비 $10.6 \%$ 증가한 이후 지속적으로 성장하며 2020년에는 전년 대비 $6 \%$ 증가한 12 억 8,000만 달러를 기록했다.51) 이는 인쇄 출판뿐 아니라 캐릭터 관련 라이선스 수입(옷, 음식, 완구류, 테마 파크 등), 그리고 마블 코믹스(Marvel Comics, 이하 마블)와 DC 코믹스(DC Comics, 이하 DC)의 IP로 제작한 슈퍼히어로 영화처럼 다른 산업과의 연계를 통해 변화에 성공했기 때문이다. 1930년대 신 문 가판대에서 1센트에 팔리던 만화 잡지 시장이 현재 미국 엔터테인먼트 산업의 확고한 자리를 차지하기까지의 미국 출판 만화 산업의 고도화 과정을 살펴본다.

49) 코믹 스트립(Comic Strip)은 신문을 통해 연재하는 한 칸 내지 한 줄 분량의 짧은 만화를 말한다. 코믹 스트립은 미국 만화가 시작된 출발점이자 만화가 출판되는 전통적 방식 중 하나로 간주할 수 있다. 그러나 출판사를 통해 매주 혹은 매달 발행하는 형식의 생산과 유통 시스템이 갖 갖추어지고 만화가 산업화한 시점은 1930년대로 볼 수 있다.

50) 슈퍼맨 시리즈는 1938년 6월 액션 코믹스(Action Comics \#1)에 처음 소개되었다. 슈퍼맨 캐릭터를 창시한 조 슈스터(Joe Shuster)와 제리 시걸(Jerry Siegel)은 "복면을 하지 않고 무시무시한 힘을 지닌 몸에 착 달라붙는 운동복을 입은 주인공'을 만들어 신문 연재만화를 기획했지만, 거절 받아 잡지라는 새로 운 지면으로 연재처를 변경했다.

51) Publishersweekly, 2020 North American Comics Sales Grow to $\$ 1.28$ Billion(2021.6.30.) 
〈표 4-2〉미국 만화산업의 고도화 단계52)

\begin{tabular}{|c|c|c|c|c|}
\hline \multirow{2}{*}{ 구분 } & \multirow{2}{*}{ 제1시기 } & \multicolumn{2}{|c|}{ 제2시기 } & \multirow{2}{*}{ 제3시기 } \\
\hline & & 제2.1시기 & 제2.2.시기 & \\
\hline 시기 & 1930년대 현재 & 1970년대 현재 & 1990년대-현재 & 1990년대 현재 \\
\hline 시장형태 & $\begin{array}{l}\text { 배급사를 통한 중개 거래 } \\
\text { (traditional distribution) }\end{array}$ & $\begin{array}{c}\text { 직거래 } \\
\text { (direct distrubtion) }\end{array}$ & $\begin{array}{c}\text { 직거래 } \\
\text { (direct distrubtion) }\end{array}$ & $\begin{array}{c}\text { 구독 서비스 } \\
\text { (subscription- } \\
\text { based service) }\end{array}$ \\
\hline 출간방식 & $\begin{array}{c}\text { 작은 잡지형태의 연재물 } \\
\text { (이슈, 호) }\end{array}$ & 연재물, 책(TPB) & 그래픽 노블 & 웹코믹스 \\
\hline 유통채널 & $\begin{array}{c}\text { 신문가판대, 작은 상점, } \\
\text { 약국 }\end{array}$ & 만화전문점 & 일반 서점 & 인터넷 \\
\hline 소비자 & 누구나 & 수집가, 팬 & 누구나 & MZ세대, 여성 소비자 \\
\hline
\end{tabular}

[그림 4-3] 2016 2020년 미국 만화 유통 채널별 시장 점유율 변화 추이53)

(단위: \%)

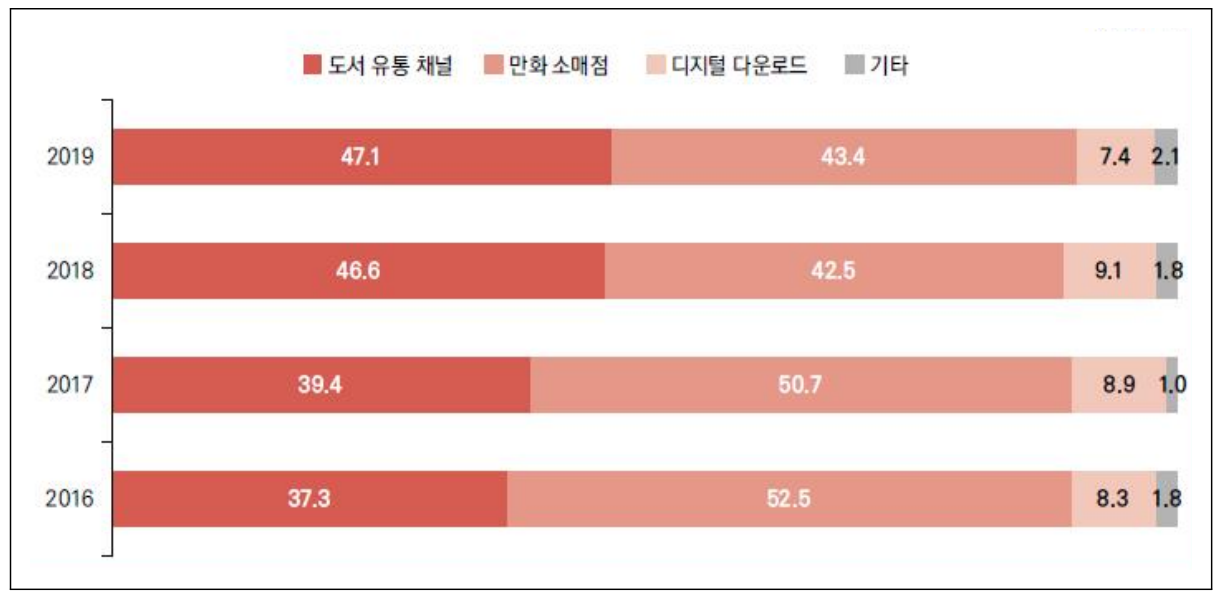

출처: ICv2. Comichron

미국 만화산업은 세 가지 주요한 전환점을 거쳐서 발전했다. 시기별 변화를 통해 새롭 게 만들어진 시장 구조는 기존의 시장과 함께 공존하며 현 만화 출판계를 지탱하고 있다. 제1시기는 1930 년 만화 출판업이 시작된 이후 출판사-도매상-소매상으로 이어지는 전 통적인 유통 방식을 통해 형성되었다. 신문 가판대, 작은 상점(mom and pop's tore),

52) David Palmer, "The Evolution of The American Comic Book Industry: Are We Entering the Third Wave?," Advances in Business Research, 1(1), 2010, pp. 232-239와 한국콘텐츠진흥원에 서 발간한 『2020년 만화 산업백서」를 참조하여 재구성함.

53) 도서유통채널(50.4\%), 만화전문점(34.4\%), 디지털 다운로드(12.5\%), 기타(2.7\%)-2020년 첨가 
약국 등 북미 전역 어디에서나 살 수 있었던 코믹북은 반품 문제라는 고질적인 산업 모 순으로 70년대 이후 급속하게 쇠퇴한다. 이후 만화전문점을 통한 직거래(direction distribution)를 특징으로 하는 제2시기가 시작된다. 마니아층을 대상으로 매주 혹은 매 달 간격으로 코믹북을 제공하는 만화전문점 유통망은 2017년까지 가장 많은 시장을 점 유한 유통 채널이다. 그러나 현재는 만화에 대한 일반 소비자의 관심이 확대되면서 만화 전문점 보다 대형 마트나 대형 서점과 같은 일반 도서 판매 채널을 통한 매출이 더 높아 졌다(한국콘텐츠진흥원. 2020). 제 3 시기는 정보기술 시대 웹 환경의 대중화로 인해 웹 코믹스가 시작된 시점으로 구분된다. 1985년 출판만화를 스캔해서 인터넷에 올리는 시 도가 처음 시작된 이후 웹만화 시장은 꾸준히 성장했고, 2020년 1,600만 달러(12.5\%) 를 차지하며 만화산업 구조에 변화를 일으키고 있다.

보는 바와 같이 각 시기는 만화라는 문화상품이 소비자에게 전달되는 유통 시스템과 긴밀한 관계를 맺으며 구획된다. 그러나 이러한 변화는 단순히 시장의 개입뿐 아니라, 만화에 대한 사회 인식, 여가의 증가로 인한 미디어 산업의 발달, 기술의 발전 등 다양한 사회·문화적 원인이 간섭하면서 이루어진 것이다. 즉, 미국 만화산업은 시기별 가장 높 은 수익을 낼 수 있는 수익 구조, 유통 채널, 그리고 이에 맞춰 생산 시스템을 다각화하 면서 분업화·고도화되었다.

\section{나. 제 1 시기- 유통의 합리화: 낮은 가격-대량 판매}

1930 년대 기존의 잡지 간행물을 취급하던 동네 소매상들은 코믹북이라는 새로운 출 판물을 처음 수급받았을 때 당황했다. 당시 유행했던 소형책자(Big Little Books)보다는 컸지만,54) 기존의 펄프잡지보다는 작았던 판형의 코믹북을 어느 곳에 진열해야 할지 난 감했기 때문이다. 그러나 1930년대 후반 32페이지 내외의 중철 컬러 인쇄 방식의 코믹 북 형식이 익숙해지고 이를 찾는 소비자들의 요구가 증가하자 만화유통이 체계화되기 시작한다. 출판사는 만화 원고의 판형을 그대로 인쇄소에 맡겨 찍은 후 배급업자에게 전달하고 배급업자는 자신의 고객인 전국의 도매상에게 상품을 수송했다. 도매상은 신문 가판대를 비롯해 식품점, 약국, 문방구, 동네 구멍가게, 버스나 기차역 상점까지 매 블록

54) 1930년대 1960년때까지 발행되었던 빅 리틀 북스(Big Llttle Books)는 200 400쪽에 달하는 작고 두꺼운 소형의 책으로 당시 인기 있던 라디오 프로그램, 만화, 동화, 소설, 영화에 관련된 내용을 담고 있다. 대략 가로 $9 \mathrm{~cm}$, 세로 $11 \mathrm{~cm}$ 의 크기의 판형에 왼쪽에는 텍스트가 오른쪽에는 흑백의 일러스트가 그려져 있다. 
마다 있었던 소매상에게 구석구석 만화책을 공급했다. 출판사, 인쇄소, 배급사, 도매상, 소매상으로 이어지는 체계화된 유통의 확립은 1970 년까지 지속됐고, 이를 통해 코믹북 은 미국과 캐나다 전역의 가장 외진 곳까지 판매가 될 수 있었다. 이러한 유통의 단일한 흐름이 가능했던 이유는 출판사 대부분이 배급사의 역할까지 담당했기 때문이다.55)

그러나 이러한 체계에 기능적 문제가 발생한다. 첫째, 도매상의 '끼워팔기(tie-in sales)'다. 이들은 소매상에게 가장 인기 있는 잡지였던 TV 가이드를 공급받고 싶으면, 덜 팔리는 혹은 ‘도덕적으로 문제가 있는' 일부 코믹북, 성인 잡지, 스캔들 잡지를 함께 살 것을 강요했다. 둘째, 1960 년대 슈퍼마켓이 북미에 전역 들어서면서 작은 상점들은 사라지고 있었다. 즉, 만화 시장의 주요 수입원인 소매상이 큰 타격을 입은 것이다. 여기 에 동네 상점을 대체한 슈퍼마켓은 코믹북 취급을 꺼렸는데 이는 전체 수입과 비교하면 코믹북 판매로 벌어들이는 수익이 미비했으며, 또한 매장에서 만화책을 읽느라 다른 손 님의 출입을 막는 것이 싫었기 때문이다.

그러나 이보다 더 큰 산업적 모순은 고질적 반품 관행이었다. 알다시피 코믹북은 1달 러도 채 안 되는 저가 상품으로 적은 이윤을 만회할 다량 판매가 필수적이다. 그러나 이러한 박리다매(薄利多賣) 전략은 오히려 부정적으로 작동했다. 소매상은 한정된 진열 장 공간을 만화책 대신 더 나은 수입원인 다른 간행물을 진열하고자 배송된 만화책은 풀어보지 않았으며, 도매상 역시 만화책을 지역 소매상으로 운송하는 비용이 더 든다는 판단이래 창고에 쌍아둔 채, 출판사에 거짓으로 판매량을 보고했다. 그리고 팔리지 않은 책을 파기한다는 조약을 어긴 채 중고상에 싼값에 팔았다.

제 1 시기의 만화산업은 낮은 가격, 적은 이윤의 코믹북을 대량으로 판매하는 전략을 추구했고, 유통의 체계화를 통해 전국적으로 만화를 보급하면서 초기에 성공을 거두었 다. 그러나 적은 이윤에도 판매를 지속했던 전통적인 소매상들이 사라지자 코믹북은 상 품으로서 가치가 절감되었으며, 잘못된 반품 관행으로 인해 출판사는 온전한 가격으로 만화책을 팔 기회를 잃어 전반적인 만화시장은 축소되었다.

55) 1954 년 가장 활발하게 코믹북을 취급했던 13 개의 대형 배급사 중 마블, DC를 포함해서 최소 7 개의 배급 사가 만화 출판업을 하였다. 


\section{다. 제 2 시기- 유통의 다각화: 만화전문점와 일반 서점}

\section{1) 직거래와 만화전문점}

만화전문점(Comic book specialty shop)을 통한 직거래 유통은 1973년 필 슬링 (Phil Seuling)에 의해 처음 시작되었다. 본인이 만화 팬이자 수입가였던 그는 이들만을 위한 만화전문점을 차렸고, 출판사가 일반 서점을 통해 직접 책을 판매하는 것처럼 배급 사나 도매상이라는 중개인을 거치지 않고 출판사로부터 직접 책을 공급받아 팔기를 원 했다. 대신 기존의 반품 관련 조약을 없애고 기존의 전통적 판매망보다 싼 값으로 공급 받기를 원했다. 그의 제안을 받아들인 만화 출판사는 만화전문점과의 직거래를 통해 정 확한 판매량을 조사할 수 있고 이에 따라 물량의 수급을 상황에 맞게 조절할 수 있다는 이점을 발견했다. 그러나 초기 만화전문점은 출판사에게 전통적인 유통 채널을 보완한 제2의 유통 채널로 받아들여졌다. 북미의 가장 큰 출판사인 마블과 DC가 2001년까지도 소매상을 통한 전통적 판매 방식을 유지한 이유는 소비자가 길거리 어디에든지 만화책 을 보고 접할 수 있다는 시장 내 '가시성'을 잃고 싶지 않았기 때문이다.56)

1980 년 마블과 DC는 만화전문점 수익을 높이기 위해 이들만을 위한 판매전략을 수 립해 큰 성공을 거둔다. 즉 만화전문점에서만 구매 가능한 책 시리즈를 만들어 판매하는 것이다. 직거래로만 취급된 시리즈에서 광고를 빼고 페이지 수를 늘리고 높은 질의 종이 로 제작하였다. 그리고 가격을 올림과 동시에 도시에 사는 비교적 고소득층에 속하는 소비자를 겨냥했다. 이러한 판매전략이 성공했다는 사실은 이때부터 만화를 둘러싼 인지 적 가치가 변화했음을 보여준다. 기존에 코믹북은 식료품점에서 장을 보다, 혹은 신문 가판대에서 신문을 보다가 심심풀이로 사보는 값싼 소비재에 해당했다. 그러나 매달 간 행되는 만화책을 구매하려고 일부러 만화전문점을 방문하고, 더불어 투기적으로 구매 및 소장한다는 것은 만화책이란 정당한 가격을 지급하고 소장하고 싶은 독특한 문화상품으 로서 받아들여졌다는 의미다.

그러나 투기적으로 만화를 사들이는 사람들과 이들을 겨냥한 출판사의 과도한 물량

56) 21세기로 들어서면서 전통적인 코믹북 유통 시스템은 완전히 사양된다. 2001년 5월 마블은 CMAA(Comics Magazine Association of America)를 탈퇴하면서 신문 가판대에서 팔리던 만화책 판매를 거의 포기했는데, 이는 전통적인 유통방식의 판매수익이 전체 수익의 $10 \%$ 도 차지하지 않았기 때문이다. 또한 만화를 사는 소비자들이 그래픽 노블 형태에 점차 익숙해지면서 32페이지의 얇은 팸플릿 형태의 만화를 어색하게 여기기 시작했다는 점에서도 그러하다. 
공세로 인해 만화시장은 일시적인 비정상적 호경기와 불경기를 반복했다. 일례로 1986 년 ‘흑백의 호황과 불황(The Black-and-White Boom and Bust)'이라는 사건이 대표 적이다. 닌자 거북(Teenage Mutant Ninja Turtles \#1)시리즈 초판이 흑백으로 출판되 자 투자가들은 이 시리즈가 나중에 큰 수익을 낼 것을 예상하고 사재기했다. 이를 눈여 겨본 사업자들은 만화사업이 돈이 될 것이라고 노리고 갑작스럽게 수백 개의 신흥 출판 사들이 생겨났으며, 모두 흑백으로 만화책을 찍기 시작했다. 이에 만화 시장은 일시적으 로 붐이 일어나지만, 1 년도 채 지나지 않아 결국 우후죽순 생겨났던 출판사, 만화전문점 은 파산을 맞는다. 투기시장이 주도하는 불안정성으로 인해 1988년 유통구조가 재조정 되고, 1994 년까지 직거래 시장은 두 개의 거대 배급사와 몇 개의 군소 배급사들로 나누 어진다. 두 개의 거대 배급사는 오늘날 준독점 위치를 차지하고 있는 다이아몬드 만화 배급사(Diamond Comic Distributor)와 위스콘신에 지부를 둔 캐피탈 시티 배급사 (Capital City Distributor)다. 반품조약이 없는 직거래유통을 유지하기 위해 이들은 매 달마다 만화전문점을 비롯해 전통적 소매상에게 앞으로 발간예정인 코믹북의 리스트를 모아둔 카탈로그(다아이몬드는 Previews, 캐피탈은 Advance Comics)를 보냈다. 여기 에는 3 개월 이내에 출시될 코믹북뿐 아니라, 수집용 카드, $\mathrm{SF}$ 소설, 롤 플레이 게임 등 다양한 아이템들이 수록되어 있었다. 이를 통해 출판사는 선주문을 받고 물량을 조절하 며 만화책 수급을 조절할 수 있었다.

만화책을 비롯해 다양한 취향의 수집품과 관련 상품을 취급했던 만화전문점은 1980년 대 말 전국적으로 2500 개로 증가했으며, 1993년에는 9400개를 넘는 숫자로 엄청난 양 적 성장을 이륐다. 그러나 여전히 투기적 성향을 겨냥하는 세일즈는 계속되었으며, 작은 중소 업체가 1년 안에 문을 닫는 일이 반복되면서 만화시장은 독과점체제로 확립되었다.

\section{2) 그래픽 노블과 일반 서점}

그래픽 노블(Graphic novel)은 두 가지 이유로 시작되었다. 첫째, 매달 발행되는 코 믹북 간행물에 더해 부가적 수입을 창출하고자 이미 출간된 6 8개의 이슈를 하나로 묶 어 일반서적(trade paperback, TPB)형태로 재출간한 판매전략에서 나왔다. 둘째, 10 대 때 만화를 읽던 소비자가 나이가 들고 경제적 위치가 높아지면서 성인으로서 즐길 수 있는 컨텐츠를 요구했다. 또한 만화 소비가 합법한 취미생활이자 만화가 예술적 가치 
를 지닌 작품으로 받아들여지길 원했다. 따라서 성숙해진 달라진 취향의 독자를 만족시 킬 새로운 포맷, 내용, 예술 가치를 시도하던 제 2 시기는 '그래픽 노블'이라는 새로운 형 태의 만화 창작을 이끌었고, 질이 낮은 페이퍼백 대신 양장본 방식의 만화책을 제작하고 일반 서점을 통해 유통되었다. 30페이지가량의 얇은 팸플릿 형태의 코믹북이 아닌 하드 커버나 양장식의 그래픽 노블의 탄생은 만화전문점이 익숙하지 않던 많은 일반 독자들 에게 만화를 접하게 해준 중요한 계기를 만들었다.

1992년 대안 만화를 이끌던 만화가 아트 슈필그먼(Art Spiegelman)은 마우스 (Maus)로 미국 만화사 최초로 퓰리처상을 타게 된다. 이로 인하여 그래픽 노블은 코믹 북하면 떠오르던 슈퍼히어로물에서 벗어나 만화만이 갖은 시각언어의 특성과 예술성을 널리 알리게 된다. 또한 주요 일간지의 문화 섹션에 평론이 실림으로 만화에 대한 인식 을 변화시키는 데 일조했다(권경민, 2013). 원래 성인 독자를 만족시킬 영업 전략의 일 환으로 선보인 그래픽 노블은 점차 하나의 장르로 자리를 잡게 되었고, 지금은 일반 서 점과 공공도서관에 '그래픽 노블'이라는 섹션이 별도로 배치되어 있다.

지금도 존재하는 제 2 시기의 만화산업 구조는 누구나 쉽게 접근 가능한 대량 유통의 체제에서 만화 전문가, 마니아, 팬, 수집가, 투자가 등 일군의 소비자층을 타켓으로 한 틈새시장을 공략했던 시기다. 이러한 만화전문 시장은 투기적 성향을 갖고 있긴 했으나 지난 50여 년간 미국 만화산업을 이끈 주력이었다. 이를 두고 이성민은 '긱(geek) 문화' 이자 '긱의 경제’라고 칭했는데, 이는 만화의 식견을 지닌 팬들을 중심으로 독자들의 취 향에 민감하게 반응하고 특정 마니아를 생산하는 취향의 경제라는 뜻이다(이성민, 2017). 그러나 이와 동시에 만화산업은 만화를 향유할 독자층 자체를 확대하기 위하여 끊임없이 노력했다. 직거래를 통해 게토화되었던 만화시장을 다각화하고 기존의 정형화 된 히어로물에 창의적이고 예술적 시도가 행해지면서 히어로물 역시 독특한 스타일로 발전하게 된다.57) 이로써 만화의 내용뿐 아니라 형식까지도 실험하며 그래픽 노블과 같 은 새로운 장르를 만들며 활로를 모색한 것이다.

57) 일례로 DC 코믹스가 1980년대 후반에 발간한 그래픽 노블인 〈배트맨: 다크나잇 리턴즈>와 〈와치맨〉은 히어로물의 한 획을 긋는 작품으로 이후 출판된 DC의 세계관과 히어로 캐릭터에 큰 영향을 주었다. 〈브이 포 벤데타〉, 〈프로 헬〉의 엘런 무어, 〈샌드 맨〉의 닐 게이먼 등은 기존의 미국 만화에서 볼 수 없었던 심리묘사와 기발한 연출로 '만화라는 매체를 재정의했다'라는 극찬을 들으며 이후 히어로 만화를 새로운 국면으로 이끌었다는 평가를 받았다. 


\section{라. 제3시기- 디지털 유통: 출판시장의 보완 및 새로운 소비자 유입}

미국의 웹코믹스(webcomics)는 1985년 에릭 밀리킨(Eric Millikin)이 자신의 개인 컴퓨터 서버를 통해 무료로 작품(Witches and Stitches)을 독자에게 배포하면서 시작 되었다. 이후 1995 년부터 본격적으로 시작된 웹코믹 시장은 전통적 만화형식과 유통에 실험적 도전을 시도하며 조금씩 성장했고, 1997년에는 빅팬더(Big Panda)라는 초기 웹 만화 전문 서버가 운용되어 800 여 명의 아마추어 웹 만화가에게 개인 작품을 올린 사이 버 공간을 제공했다(이성민, 2007). 2000년에 킨스팟(Keenspot)이라는 유료 콘텐츠 웹 만화 포털이 등장했고, 광고 기반 수익모델을 도입했으나 큰 성공을 거두지 못했다. 이 는 대형 출판사들의 투자가 제한적이었기 때문이다. 물론 출판사에게 웹코믹스는 새로운 수입원이자 실험적 만화를 시도하는 신세대 작가들을 포섭할 통로로 여겨졌다. 그러나 기존의 안정적인 출판시장에서 벗어나 예측 불가능한 새로운 비즈니스 모델로의 이동은 위험부담이 크다고 판단됐다. 이를 보여주는 단적인 예가 2007년에 마블이 시작한 웹기 반의 무제한 구독 서비스(Marvel Digital Comics unlimited)다. 월간/연간 소정의 이 용권 결제로 기존 마블 만화를 무제한 볼 수 있는 이 서비스는 오직 기존 만화에 대한 접근 뿐, 새롭게 출간될 이슈에 관해서는 6 개월이 지나야 웹으로 볼 수 있게 제한했다. 즉, 미국의 디지털 만화는 기존의 출판시장을 잠식하는 전략이 아니라, 오히려 인쇄 만 화의 판매를 보완하는 유통 창구로서 여겨졌다고 볼 수 있다.

2003년 iTunes 시장이 열리고 단일 플랫폼을 통해 음악, 서적, 영화, 게임 등과 같은 미디어 컨텐츠가 유통 및 소비되는 상황이 벌어지자, 2007년 만화를 위한 iTunes를 표방 한 코믹솔리지(comiXoogy)가 만들어진다. 코믹솔로지는 기존 만화의 스캔본 파일을 다 운받아 소장하는 형식이 아니라, 아이폰이나 아이패드에서 앱을 사용해 그 안에서 컨텐츠 를 결제하고 볼 수 있는 웹서비스를 제공했다. 또한 가이디드 뷰 기술(Guided View Technology)를 도입하여58) 한국 웹툰의 세로스크롤링과 다른 방식의 '만화 읽기'를 도 입했다. 또한 클라우드 기반의 디지털 저작권 관리 모델로서 독자가 계정을 만들고 로그인 하여 콘텐츠에 접근하는 방식이기 때문에 웹사이트에서 $\mathrm{pdf}$ 를 다운받거나 이북 파일을

58) 가이디드 뷰는 작은 화면의 아이폰이나 아이패드 스크린에서도 인쇄형식의 만화를 볼 수 있도록 해주는 뷰잉 기술로서, 한국 웹툰처럼 스크린에 맞도록 칸을 떼어 세로로 정렬하는 형식이 아니라, 페이지 만화 포맷을 그대로 유지한 채, 각 칸마다 초점이 자동적으로 이동하면서 독자를 가이드하는 보기 형태를 제공한다. 이는 독자가 기존의 페이지 만화를 눈으로 따라 읽어가는 형태와 흡사한 독서 뷰잉 기술이라고 할 수 있다. 
소유하지 못한다. 마블, DC 같은 대형 출판사뿐 아니라 중소 출판사를 비롯해 일본 망가 작품까지 다양한 콘텐츠를 제공하고 있으며, 유저들이 만화를 쉽게 찾을 수 있도록 하는 전략을 세웠다. 코믹솔로지는 2014년 4월 애플 앱스토어에 높은 순위를 기록하며 아마존 에 인수되었고, 이후 미국 내 주요 디지털 만화 유통 플랫폼으로 자리 잡았다.

기존의 각 이슈별 접근권을 사는 방식의 iTune 비즈니스 모델이 사양 되고, 월정액권 을 구입하여 일정 기간 거의 무제한의 작품에 접근할 수 있도록 하는 구독 서비스 (susbscrption-based service)로 바뀌었다. 아마존이 유저가 읽은 페이지별 수익을 측 정하는 방식의 킨들 언리미티브 구독 서비스(Kindle Unlimited subscription servie) 를 제공한 것처럼, 디지털 만화 역시 자유이용권 방식이 선호되고 있다.

물론 현 디지털 만화는 미국 만화 시장 전체의 $10 \%$ 대를 차지하며, 출판만화 시장을 보조하는 부스터 역할로 여겨져왔다. 그러나 일부 마니아층에 국한되어 있는 만화전문점 이 아닌 신규 소비자를 유입할 가장 역동적인 유통 채널이 되고 있다. 이는 중장년층 남성 팬덤이 주류를 이루는 배타적인 만화점에서 벗어나 다양한 만화를 즐기고자 하는 여성 중심의 새로운 독자층, 소장에 가치를 두기보다 디지털로 만화를 즐기는 것에 익숙 한 젊은 세대를 유입할 수 있기 때문이다. 특히 코로나19로 인해 2020년 마블, DC는 온라인, 비대면 판매가 가능한 디지털 출판 방식을 강화하거나 새로운 유통업체와 계약 을 체결했다는 점에서 드러난다(한국콘텐츠 진흥원, 2020).

\section{2. 제작 시스템 및 구조}

\section{가. 스튜디오}

전통적으로 미국의 만화 생산은 1 인 작가 체제가 아닌 다수의 작업자가 공동으로 창작하 는 협력체제에 의존해왔다. 이는 미국의 영화, 애니메이션과 같은 여타 미디어 산업과 비슷 한 생산방식이다. 즉, 1 인 작가(author)가 만드는 예술 만화나 대안 만화(Alternative comics)가 아닌 상업적으로 대량 판매를 위해 제작하는 만화는 대부분 '스튜디오(Studio, 혹은 shop)' 혹은 속칭 작업장(Sweatshop)이라고 불리는 방식으로 제작된다.

전통적으로 코믹북은 한 달에 한 번 새로운 이슈가 나온다. 그러나 2008년 이후 DC 는 매 3 주마다 마블은 매달 2번(double-shipping) 새로운 이슈를 발간하는 예도 잦아 
졌다. 이처럼 생산 주기가 짧아지고 경쟁이 심화할수록 만화 생산에서 가장 중요한 것은 '속도'와 '협력'이다. 따라서 미국의 거대 출판사인 마블과 DC는 가장 효율적인 생산 라 인을 만들기 위해 일을 분업화하고 팀별 혹은 프로젝트별로 묶어 동시에 여러 작업이 진행될 수 있도록 작업팀을 운영한다.

〈표 4-3〉 제작과정의 분업화

\begin{tabular}{c|c|c|c}
\hline 단계 & 제작명 & 내용 & 담당자 \\
\hline 1단계 & 편집회의 & $\begin{array}{c}\text { 편집자와 글작가가 작품에 대한 아이디어를 } \\
\text { 나누고 발전시키는 과정 }\end{array}$ & $\begin{array}{c}\text { 편집자(Editor), } \\
\text { 글작가(Writer) }\end{array}$ \\
\hline 2단계 & 플롯 짜기 & $\begin{array}{c}\text { 의논된 아이디어에 맞춰 스트립트를 작성하고 } \\
\text { 플롯의 얼개 만들기 }\end{array}$ & 글작가(Writer) \\
\hline 3단계 & 얼개그림 작성 & $\begin{array}{c}\text { 스크립트에 맞추어 각 페이지마다 칸을 나누고 } \\
\text { 칸마다 그림, 말풍선 배치하여 얼개그림 작성 }\end{array}$ & 펜슬러(Penciller) \\
\hline 4단계 & 잉크칠하기 & 얼개그림의 연필 선을 따라 잉크칠하기 & 잉커(Inker) \\
\hline 5단계 & 레터링 & 대사나 나레이션 넣기 & 레터러(Letterer) \\
\hline 6단계 & 컬러링 & 색깔을 입혀 그림 완성하기 & 컬러리스트(Colorist) \\
\hline 7단계 & 선-인쇄 & 수정작업 및 보완 & \\
\hline 8단계 & 인쇄 & 책형대로 인쇄 & \\
\hline
\end{tabular}

\section{1) 일의 분업화}

보통 새로운 시리즈를 발전시키고 아이디어를 고민하는 1 단계 편집회의는 6 개월의 시간이 소요되지만, 어떻게 시리즈를 끌고 갈지 의논이 끝난 이후에는 한 권(이슈)의 책 이 제작되는 데 대략 6 주의 시간이 걸린다. 이때 작가는 2 주 동안 스크립트를 쓰고 나머 지 4주간 그림이 완성된다.

[그림 4-4] 미국 만화 제작 과정59)

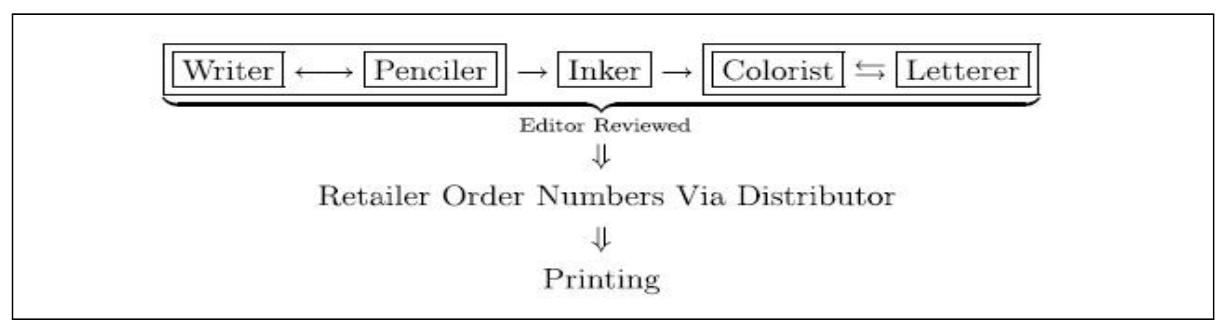

59) Jerry Hionis, YoungHa Ki(2019), The economics of the modern American comic book market, Journal of Cultural Economics, 43, pp 548. 


\section{2) 담당 역할}

(1) 편집자

편집자는 프로젝트를 진행할 적합한 만화작가들을 모아 하나의 팀을 구성하고, 팀원 들간의 원활한 소통이 될 수 있게 창구 기능을 한다. 단계마다 결과물을 체크하며, 작품 이 완결되기까지 모든 과정을 총괄한다. 편집자는 스토리 제안, 작품의 질 관리, 마감일 준수 등 예술적인 감각과 더불어 행정 능력까지 갖추어야 하며, 무엇보다 출판사와 만화 작가 사이의 이익 관계를 조율하는 자로 중요한 임무를 맞는다. 현재 DC나 마블에서는 편집자의 중요성이 훨씬 더 커지고 있는데, 이는 '세계관'을 공유하는 스토리가 많아지 고, 여러 캐릭터가 다른 작품에 출현하는 '크로스-오버'가 자주 연출되기 때문이다.

(2) 글작가

작품 제작과정에 있어서 가장 중요한 위치와 높은 자율성, 그리고 가장 큰 수입을 받 는 글작가는 기존의 캐릭터를 맡아 스토리를 이어가거나, 혹은 새로운 이야기를 쓰는 일을 한다. 글작가는 한 시리즈 전체 플롯을 결정하고, 플롯을 각 이슈에 맞게 나누어, 매화마다 스크립트와 요약본을 작성한다. 이들의 작업방식은 두 가지로 나뉘는데, 마블 메소드(Marvel Method)를 선택할 경우, 가장 기본적인 스토리 라인만 잡은 후 펜슬러 와 의논하며 각 페이지의 칸구성과 대사를 결정한다. 그러나 이보다 더 일반적인 방식은 영화 대본과 비슷하게 각 이슈마다 자세한 스토리 설명과 함께 칸의 모양과 인물 묘사까 지 세부적으로 지시하는 경우도 많다. 때로는 간략한 스케치 형식의 썸네일을 그려 넣는 경우도 있다.

(3) 펜슬러

펜슬러는 보통 아티스트(artist)로 불린다. 만화의 ‘비주얼 스토리텔링(visual storytelling)'을 담당한다고 해도 과언이 아닌 펜슬러는 스토리가 독자에게 더 효과적으 로 전달될 수 있도록 전체적인 '그림'작품을 만들어내는 자다. 최근에는 종이가 아닌 디 지털을 이용해 작업하는 경우가 점점 더 많아지고 있다.

(4) 잉커

컬러리스트, 레터러와 함께 테크니션(technical worker)으로 불리는 잉커는 스토리 
에 전혀 관여하지 않고 특정 예술 기술을 발휘하여 작품을 완성한다. 잉커는 펜, 붓, 잉 크를 사용하여 펜슬러가 그린 선위를 따라가며(트레이싱 기술) 선에 깊이, 명암, 질감을 주어 작품 전체에 움직임, 생동감, 무게감을 더하는 만화가다.

\section{(5) 컬러리스트}

만화 생산에 디지털 작업이 만연해지면서 잉커의 역할은 축소되는 반면, 컬러리스트 의 역할 폭과 중요성은 점차 커지고 있다. 디지털 툴이 제공하는 붓과 색깔, 이펙트는 빠르면서도 더 넓은 영역의 표현이 가능하기 때문에 컬러리스트는 예술적 시도와 창작 의 자유를 갖게 된다.

(6) 레터러

만화 공정에서 가장 낮게 인지되는 레터러는 말풍선 대화, 자막, 사운드 특수효과를 담당하는 자다. 만화에서 글자는 단순히 이야기 전달이 아닌, 하나의 시각적 표현으로 간주하기 때문에, 캘리그래피적 효과를 담당하는 테크니션이라고 볼 수 있다.

\section{나. 스튜디오 시스템의 고도화}

1) 불펜(Bullpen)

현 스튜디오 시스템의 전신이라 불리는 불펜은 1937년 만화가 윌 아이즈너(Will Eisner)가 처음 시도했으며 1980년대 초까지 유지되었다. 불펜은 테일러리즘 (Taylorism)에 입각해 만화 제작을 마치 공장의 생산 라인처럼 업무를 철저히 배분하고, 엄격한 순서에 따라 만화를 작업하는 방식을 말한다. 이를 위해 편집자와 예술가는 뉴욕 이나 로스앤젤레스와 같은 대도시에 있는 출판사와 가까운 곳에 함께 모여 일했다. '툭 트인 넓은 사무실'이라는 뜻의 불펜은 이러한 협업의 작업구조를 지칭하는 말이다.

그러나 정교한 작업 배분은 '창작'으로서 만화가 갖는 기본 가치를 해치기도 했다. 편 집자는 각 과정을 마친 결과물을 매 순간 살피고 결정하는 절대적 권한을 갖고 있었기 때문에, 특정 캐릭터의 향방과 스토리를 이끄는 선임 작가(writer-in-chief)와도 같았 다. 따라서 이미 결정된 스크립트는 이후 작업하는 작가에 의해 변경되거나 창의적인 아이디어를 제안하는 등의 수정을 할 수 없었다. 따라서 불펜을 통한 결과물은 하나의 창작품으로서 경직성을 보였다. 


\section{2) 마블 메소드(Marvel Method)}

'마블 불펜(Marvel Bullpen)'이라고도 불리는 마블 메소드는 불펜보다는 좀 더 유연 한 창작방식을 갖고 있다. 이를 창시한 마블의 스탠 리(Stan Lee)는 모든 대사, 장면, 상황이 적혀진 완전한 스크립트를 작성하지 않고, 그림작가(보통 펜슬러)를 먼저 만나 어떠한 방향으로 가면 좋을지 대략 아이디어를 나눈 후, 계속 의논하며 얼개그림을 완성 해나가는 방법이다. 따라서 글작가는 각 페이지의 그림이 완성된 이후에야 말풍선의 대 사를 쓰기도 했다. 당시만 해도 만화 작업은 '글을 기초로 한 작화' 였다고도 볼 수 있다. 그러나 마블 메소드는 기존의 과정을 뒤집는 시도, 글과 그림이 서로 협업하여 최상의 결과물이 나올 수 있도록 하는 생산과정이었다.

이로 인하여 마블은 큰 성공을 거두었지만, 이후 저작권 분쟁의 원인이 되었다. 앞서 설명한 바와 같이 글작가가 초기 아이디어를 생각해 낸 이후, 이를 시각적으로 표현하고 스토리를 다듬어가는 전 과정은 글작가와 그림작가의 창의적 협업을 통해 이루어지기 때문에 누구의 아이디어였는지 판가름하기가 불가능하다. 그러나 마블의 경우에는 글작 가(스탠 리)가 그림작가(잭 커비(Jack Kirby)와 스티브 디코(Steve Ditko)보다 작품에 대한 지분과 명예가 훨씬 더 많이 주어졌다.

\section{3) 프리렌서 모델(free-agent model)}

90년대 중반 이후 통신기술의 발달은 출판사의 작업구조와 방식에 크게 영향을 끼쳤 다. 출판사는 제작비를 줄이기 위해 사내 상주하는 정직원을 줄이고 프리랜서 만화가를 프로젝트별로 고용하는 것을 선호했다. 특히 대형 출판사들은 최대한 마케팅에 집중하 고, 만화 작업은 고도화된 전문가들 집단과 네트워크를 통해 단기 고용 계약 (Work-for-Hire)을 맺는 방식으로 일했다. 이러한 생산 모델은 기존 불펜처럼 만화가 들이 함께 모여 일할 장소가 필요 없으며, 만화가 역시도 출퇴근하지 않고 자신의 집이 나 가까운 작업장에서 일할 수 있는 이점이 있었다. 그리고 한 출판사가 아닌 여러 출판 사와 프로젝트별 작업을 동시에 수행할 수 있었다.

이는 고도로 분업화된 작업 플로우(flow)가 오랜 기간을 거쳐 만화산업 내에 자리를 잡았기에 가능할 일이었으며, 동시에 전화를 비롯하여 이메일이나 화상통화 등 값싼 통 신기술로 인해 거리에 구애받지 않고도 충분한 협업이 가능해졌기 때문이다. 또한 저작 
권에 대한 법적인 절차 역시 여러 판례를 통해 안정화되었기에 프리랜서 계약이 산업 내에 통용될 수 있었다. 현재 출판사는 수익성을 최고로 높이고 더 넓은 풀의 고용 네트 워크를 확보하기 위해 자국을 넘어 해외의 만화가도 적극적으로 고용하고 있다. 예를 들어, 편집자는 뉴욕 본사에서 일하지만, 펜슬러와 잉커는 스페인에서, 컬러리스트는 하 와이에서, 그리고 다시 뉴욕 편집자의 모든 승인이 떨어진 후 앨라배마에서 인쇄하여 완제본을 만든다. 이 모델은 지역과 장소에 구분 없이 실력 있는 만화가를 고용할 수 있다는 장점이 있지만, 갑작스런 작화 스타일의 변화나 스토리의 파격을 꺼리는 단점이 있다. 이는 세부 스케줄에 따라 엄격히 데드라인을 맞추지 않으면 매달 나와야 하는 책 생산에 차질이 생기기 때문에 새로운 시도보다는 정확한 마감을 지키는 것이 더 중요하 며, 이미 확보된 독자를 유지하기 위해 ‘위험하다’ 고 여겨지는 파격 설정은 잘 받아들여 지지 않기 때문이다.

또한 프리랜서 모델은 만화가에게 여러 가지 이점과 동시에 불안감을 가져왔다. 정규 직이 아닌 단기 노동자-예술가로서 페이지당 혹은 프로젝트별로 수입을 받기 때문이다. 따라서 만화가는 고용불안을 해결하기 위해 끊임없이 구직 시장에 자신을 알리고, 생계 를 위해 수 개의 프로젝트를 동시에 작업하는 시례가 다반사다. 또한 작업하는 작품에 대한 어떤 저작권 수익도 가질 수 없을 뿐 아니라, 갑작스럽게 프로젝트가 결렬되는 경 우가 생기는 등 장기적인 수입원을 찾기가 쉽지 않다. 더불어 편집자를 제외하고는 프로 젝트가 끝날 때까지 함께 투입되었던 다른 작가들을 만날 기회가 자주 없다. 따라서 심 리적으로 고립되어 있을 경우가 많으며, 협업임에도 불구하고 ‘함께’ 일한다는 기존의 불펜-스튜디오 개념은 사라졌다고 볼 수 있다.

\section{다. 1 인 작업}

마블과 DC와 같은 대형 출판사가 주력하는 슈퍼히어로 만화는 프로젝트별 전문가가 하나의 팀을 이뤄 철저한 분업화와 세부 일정에 따라 작업하는 스튜디오 시스템을 주로 사용한다. 그러나 매달 주기별 발행해야 하는 시리즈물이 아닌 자전 만화, 대안 만화, 실험 만화와 같은 그래픽 노블은 작가의 자율도가 높고, 대부분 오랜 기간 공들여 작업 하기 때문에 개인 스튜디오에서 1인 창작이나 2 3명의 공동창작으로 이루어진다.

마블과 DC로 대변되는 '빅 투(Big Two)'와 경쟁하는 중소 출판사는 이와 다른 생산 
시스템과 고용형태를 통해 마켓 쉐어를 점유하려고 노력한다. 다크 호스 코믹스(Dark Horse Comics), 이미지 코믹스(Image), IDW, BOOM! Studios와 같은 출판사들은 만화가들에게 더 많은 창작의 자유를 주며, 콘텐츠의 소유권 역시 출판사와 작가가 함께 나누는 라이센스 계약을 맺고 있다. 이를 통해 작가는 예술가로서 정체성을 확립하고 자신만의 스타일의 작품을 생산할 여건을 갖는다. 출판사 역시 작가와 리스크를 나누고 기존과 다른 새로운 작품을 시장에 내놓는 모험을 감행할 수 있다.

디지털 만화 시장 역시 기존의 스튜디오 시스템과 다른 작업 환경과 수익계약을 만들 수 있다. 현재 디지털 코믹스는 작품을 다운받아 파일을 소유하는 형식이 아니라, 웹에 서 콘텐츠를 읽고 접근하는 '무제한 서비스'를 제공하기 때문에, 출판시장과 달리 작가 에게 라인센스를 줄 가능성이 크다. 또한 메이저 출판사가 독점하는 만화전문샵과 달리 유저가 직접 찾고 선택하는 디지털 유통망을 통해 만화작가는 대중에게 자신의 이름을 직접 알릴 기회를 얻을 수 있다.

\section{3. 유통 시스템 및 구조}

\section{가. 유통 구조}

미국 만화시장은 크게 4가지 유통 채널로 나뉜다. 먼저 꾸준히 성장하여 2018년 이후 가장 많은 비율을 차지한 일반 서점방식, 둘째 반품 없는 직접유통을 통해 팬 중심으로 형성된 만화전문점 방식, 셋째 웹코믹스를 다운/구독하여 읽는 디지털 판매방식, 그리고 마지막으로 고전적인 유통 방식인 신문 가판대, 소매점, 약국 등의 전문 소매점 방식이다.

현 미국 출판만화의 유통은 ‘모래시계 구조(hourglass structure)'로 설명할 수 있다. 이 모델은 많은 수의 콘텐츠 제작자와 개인 아티스트에 비해 적은 수의 매우 집중화된 다국적 기업의 유통사가 거대한 소비자층의 접근을 제한하는 형태를 말한다. 이 구조는 1997년 마블이 경제적으로 위기에 처해 자신이 소유했던 배급사 히어로스 월드(Heroes World)를 포기하고 다이아몬드 배급사가 도매 유통의 독점적 위치를 차지하면서 만들 어졌다. 그러나 근 30년간 다이아몬드 배급사를 중심으로 안착된 출판유통 구조가 코로 나19와 함께 변화를 겪고 있다. 만화전문점 유통이 아닌 일반 도서 판매 채널을 통한 매출이 점점 늘어나는 현상과 더불어 코로나 19 로 이동 제한과 자택 격리 등 외부 활동인 
강제적으로 중단되면서 미국 만화책 배급이 6주간 전면 중단되는 사태까지 일어났기 때 문이다. 이는 만화 총판으로 북미 전역의 출판사와 만화 전문점과 소매상의 중간유통을 맡아온 독점 체제에 근본적인 변화를 암시할 수 있다.

미국 만화산업의 또 다른 특색은 디지털 만화시장이 기존 출판만화 시장을 경쟁하거 나 잠식하기보다는 서로를 보완, 확장하는 형태로 발전해왔다는 점이다. 이는 오랫동안 만화전문점을 중심으로 형성된 탄탄한 마니아층이 출판만화를 물리적으로 구매, 소장하 는 소비행태를 유지하고 있기 때문이다. 더불어, 거대 출판사들이 디지털 매체로 콘텐츠 를 향유하는 데 익숙한 신세대 소비자층을 유입하고자 기존의 유통망을 유지한 채 새로 운 비즈니스 모델을 실험하고 있다고 볼 수 있다.

\section{가. 일반 서점}

15년 전만 해도 피너츠(Peanuts)와 같이 신문 코믹스트립을 묶어서 판매하는 책이나 잡지 가판대를 통해 이미 인기를 검증받은 몇몇 작품을 제외하고는 일반 서점은 거의 코믹북을 취급하지 않았다. 그러나 2000년대 이후 히어로 만화가 TV 애니메이션이나 할리우드 영화(2000년 엑스맨, 2002년 스파이더맨)로 제작돼 큰 인기를 얻게 되면서 그 원작인 만화에 대한 소비자들의 관심이 높아지기 시작했다. 이에 마블과 DC는 30 40년대 연령층에게는 향수를 자극하는 상품이자, 어린 소비자에게는 캐릭터를 노출 하고자 슈퍼히어로 컬렉션을 제작해 일반 서점에 유통했다. 여기에 70년대 언더그라운 드 만화의 전통을 간직한 자전적 만화의 스토리텔링을 고수한 작가들은 시장성과 예술 성을 지닌 그래픽 노블을 선보였다. 이후 현재까지 그래픽 노블은 작가-주도적 생산방식 을 사용하는 독립 출판사를 통해 생산되고 있다. 대표적인 독립 출판사는 판타그래픽스 (Fantagraphics), 드러운 앤 콰터리(Drawn \& Quarterly), 탑 쉘프(Top Shelf)가 있 다. 가장 먼저 '빅 투'에 반기를 든 판타그래픽스는 1993년 크리스 웨어(Chris Ware)가 출간한 '지미 코리건: 세상에서 가장 똑똑한 아이(Jimmy Corrigan, The Smartest Kid on Earth)'로 모든 만화상을 석권하며 명성을 쌍았다. 판타그래픽스는 상업적 제약 에 벗어나 작가의 창의력을 독려하는 작업 환경을 고수하며 질과 양적인 면에서 독립 출판시장을 이끌고 있다.

2010년 들어서 마블 시네마틱 유니버스(MCU) 세계관을 담은 히어로 영화들이 전 세 
계적으로 붐을 일으키며 일반 서점을 통한 그래픽 노블의 판매가 지속해서 증가하고 있 다. 즉 만화의 IP를 활용한 인접 콘텐츠 산업의 증가에 따른 그래픽 노블의 선전이다. 더불어 만화에 대한 인식이 개선되면서 아동과 청소년들을 중심으로 한 아동용 그래픽 노블의 판매도 증가했다. NPD 북스캔의 분석에 따르면 2021년 상반기 미국 인쇄 출판 도서 시장은 $2 \%$ 선의 성장을 예상하는데, 주요 원동력으로 그래픽 노블과 청소년 소설 (young adult fiction)을 뽑았다.60)

\section{나. 만화 전문점}

미디어 산업의 디지털화에도 불구하고 물리적인 책 형태의 출판물을 사고파는 만화 전문점은 하락세가 아닌 완만하지만 꾸준한 곡선을 이루며 성장해왔다. 이는 단순한 규 모의 경제로 해석되기보다 오랫동안 취향을 중심으로 형성된 독특한 북미의 만화 소비 문화 때문이다. 매달 코믹북이 나오길 기다렸다가 사고 모으는 관행은 전통적인 긱 (geek) 문화형 만화 향유가 여전히 굳건함을 보여준다. 일례로 2012년 기념비작인 워킹 데드(Walking Dead)의 100 번째 이슈가 발간되었을 때 13 개의 다른 표지로 각각 발매 되었으며, 99번째 이슈 판매량의 4배에 달하는 38만 부 이상이 팔렸다. 이렇게 같은 이 슈를 다른 커버로 만들어 파는 행위는 90년대부터 계속된 '듀얼커버(dual cover)' 판매 전략으로, 같은 내용이라도 커버가 다르면 재구매하려는 소비자의 수집가 심리와 인쇄 출판 만화에 대한 애착이 없다면 불가능한 일이다.

또한 만화전문점은 코믹북 뿐 아니라 관련 상품을 함께 묶어 판매하여 차별적 수익을 올린다. 일례로 매월 긱들을 위한 여러 관련 상품을 하나의 상자에 담아 구독자에게 제 공하는 루트 크레이트(Loot Crate)는 이 안에는 코믹북뿐 아니라 관련 피규어, 소설책, 티셔츠 등을 함께 넣어 판매한다. 루트 크레이트는 2014년 마블의 Rocket Racoon \#1 에 관련된 루트 박스를 제공했고 판매수익을 최고로 올렸다. 이러한 관련 상품의 존재는 출판 자체의 추가 수익을 올려줄 뿐만 아니라, 역으로 작품 자체의 인지도 역시 올려주 며 선순환 경제를 만든다(이성민, 2017)

그러나 기존의 중장년 남성 중심으로 형성된 만화전문점 시장은 점차 일반 대중을 폭 넓게 만날 수 있는 대중적 채널에 이동하고 있으며, 오프라인 매장 운영 대신 온라인

60) Publishers Weekly, Print Book Sales Could Grow by 2\% This year-Or by 8\%(2021.7.26.) 
주문이 및 우편 배송 등으로 운영 방식이 변경되고 있다. 이러한 만화책 유통업계의 지 형변화는 코로나19로 인한 더욱 가속화될 전망이다.

\section{라. 디지털 유통}

현재 ‘미국 최대의 디지털 코믹스 소매점’이라고 불리는 코믹솔로지는 특정 출판 브랜 드와 연결된 브랜드 독점형 서비스가 아닌 디지털 포맷의 만화를 유통하고 출판하는 디 지털 코믹스 플랫폼이다. 따라서 출판만화 시장의 다이아몬드 배급사와 같은 독점적 지 위를 갖지 않는다. 마블과 DC 코믹스가 자신들이 출판한 거의 모든 코믹스를 온라인으 로 제공하는 웹사이트와 모바일 어플리케이션을 갖고 있으며, 월 정액제나 무제한 구독 서비스를 제공하고 있다.61) 이외에 제3의 출판사인 다크호스 코믹스나 이미지 코믹스도 온라인 디지털 만화 스토어를 게시해서 서비스하고 있다.

디지털 만화가 유통되면서 출판사가 가장 많은 우려한 부분은 불법복제에 대한 위협 이다. 불법 복제 콘텐츠가 만화 시장 전반의 매출 감소를 가져왔다는 추측과 논쟁으로 여타 디지털 미디어 산업과 달리 만화는 기술진보를 통해 산업이 발전하는 혁신적인 단 계로 과감하게 이행하지 못했다. 또한 출판사는 디지털 판매로 인하여 물리적인 책 판매 가 타격을 입을지 모른다는 만화전문점의 불만과 우려를 걱정한다. 다크호스 코믹스가 책 출판을 동일 날짜에 더 싼 가격으로 디지털로 출판하겠다는 소문이 퍼지자 만화전문 점은 보이코트를 통해 출판사를 압박한 일도 있었다. 따라서 출판 유통 네트워크와 좋은 관계를 유지해야 해야 하는 메인 출판사들은 여전히 안정적인 수익을 보장하는 출판 비 즈니스 모델을 유지하고, 이를 확장, 보완하는 방식의 디지털 코믹스를 판매하고 있다. 먼저는 디지털 만화 콘텐츠를 새롭게 제작하지 않고, 기존의 작품의 연계성을 유지하며 프로모션의 일환으로 디지털 판매망을 이용한다. 또한 기존의 단기 고용 협약에 의해 제작한 콘텐츠에 관해 어떠한 저작권도 소유하지 못했던 작가들에게 디지털 판매에 기 초한 판매량에 따른 저작권비를 소정 지불하는 인센티브를 허용했다. 이는 실력 있는 만화가들과 지속적인 고용 관계를 유지하고, 경쟁사로 가지 않도록 잡아두기 위함이다.

그러나 점차 디지털 유통이 산업적으로 확장되면서 같은 날 같은 가격으로 작품을 출

61) 현재 코믹솔로지는 월 6 달러, 마블은 월 10달러, 년 70달러, DC는 월 8달러, 년 75달러에 무제한 서비스 를 제공하고 있다. 
판과 디지털로 동시에 출시하는 모델이 받아들여졌다. 만화를 어떠한 형식으로 읽고 소 비할지는 독자가 선택하도록 맡긴 것이다. 또한 불법복제에 관해서도 코믹솔로지가 만든 디지털 권리 관리(Digital rights management) 소프트웨어의 사용하도록 방법을 간구 했으며, 이것 역시 출판사 혹은 창작자의 선택에 따라 자유롭게 이용하도록 했다. 현재 이미지 코믹스는 DRM-free를 선언했고, 마블과 DC는 유지하고 있다.

만화전문점의 숫자가 줄어들고, 일반 서점의 유통이나 온라인 디지털 시장이 확대된 지금, 디지털 유통의 확장성을 확신한 출판사들은 온라인을 통한 판매 확보에 열을 올리 고 있다. DC는 디지털 퍼스트 전략(Digital-First Policy)를 세워 출판만화보다 디지털 코믹스를 먼저 출시할 작품 라인을 늘렸다. DC와 마찬가지로 마블 역시 오직 디지털로 만 출판하는 작품 리스트를 발표했다. 그러나 코로나19이후 직거래 시장이 힘들어지면 서 오직 온라인으로만 출시하겠다고 발표했던 작품을 몇 달 지나지 않아 다시 프린트로 제작하겠다고 변경했다. 이는 인쇄 출판 만화의 점유율을 빼앗기지 않으려는 출판사의 노력이자, 디지털 시장은 만화산업의 부가적 수입이자 출판 만화를 위협해서는 안된다는 인식이 작동하고 있음을 보여준다.

\section{4. 해외진출 관점에서의 시사점}

\section{가. 장르의 다양성 추구}

미국 만화산업은 주간 혹은 월별로 연재되는 코믹북 생산 스케줄에 맞추기 위해 콘텐 츠 제작을 고도로 분업화하고 협업이 가장 효율적으로 이루어질 수 있는 스튜디오 시스 템을 발달시켰다. 만화가 하나의 문화 산업으로 자리를 잡기 위해 필연적으로 등장한 이러한 대량생산체제는 웹툰이 산업화가 된 최근 한국에서도 비슷하게 나타나고 있다. 한국의 출판 만화시장은 전통적으로 만화가 1 인 창작체제에 가깝다. 물론 유명 만화가가 개인 화실에 몇 명의 문하생을 둔 도제식 작업장을 운영하기는 했지만, 스토리부터 그림 까지 자신의 이름을 걸고 만화를 출판해왔다. 그러나 웹툰이 등장하여 일주일에 1 번 혹 은 2 번으로 연재주기가 빨라지고 흑백이 아닌 올 칼라 만화가 일반화되면서 분업화가 불가피하게 된 상황이다. 또한 양질의 콘텐츠를 수급받기 위해서 네이버와 카카오페이지 는 자사 내 스튜디오를 설립하거나 역량 있는 외부 스튜디오와 협업 관계를 맺고 있다. 
즉, 한국 만화산업의 고도화, 분업화가 이미 시작되었다고 볼 수 있다.

물론 미국 출판만화 시장은 슈퍼맨의 탄생 이후 수백 개의 맨류와 (마법)사류를 출시 하면서 인접 미디어 산업과의 연계를 통해 거대한 IP왕국을 만들어냈다. 그러나 단계별 고도화되는 과정에서 보았듯이 이러한 고도의 분업화는 만화라는 예술 창작에 있어 획 일성을 가져온다. 즉, ‘속도'와 '효율’에 집중한 스튜디오 시스템은 수직적 체계와 경직 된 권한이라는 취약점으로 인해 히어로물이라는 장르의 고착, 상업화의 심화, 다양성을 회피 등이 문제점을 안고 있었다. 그러나 똑같은 플롯과 설정의 반복으로 한계를 보였던 히어로물이 새로운 활로를 찾고 변화할 수 있었던 이유는 고착된 장르를 파괴하고자 한 예술가적 실험정신이 있었기 때문에 가능했다. 이는 창작가로서 역량 있는 영국 작가들 이 마블이나 DC의 미국 작가와 협업하면서 이루어지기도 했고, 70년대 언더그라운드 만화(underground comics) 혹은 대안 만화(alternative comics)를 통해 예술가의 맥 을 유지했던 작가들의 창작을 통해서 일어나기도 했다. 결국 그래픽 노블로 대변되는 장르의 다양화는 자칫 침체할 수 있었던 미국 만화시장에 일반 서점이라는 새로운 유통 활로를 개척하는 견인차 구실을 했다.

따라서 산업이 고도화될수록 장르의 다양성이 추구될 필요가 있다. 즉 다양한 독자의 취향을 만족하게 할 수 있고 작가로서 예술적 자율도가 주어지는 1 인 창작이나 독립 만 화 출판도 함께 공존해야 한다. 따라서 현 미국 출판시장이 긱들의 경제에서 일반 대중 으로 소비자를 확대하면서 만화라는 문화콘텐츠의 시장을 키워나가고 있듯이, 한국의 웹 툰 산업 역시 고도화될수록 이로 인해 필연적으로 수반되는 획일성을 보완할 다양성의 만화를 전략적으로 지원하고 생산할 필요가 있다.

\section{나. 저작권에 대한 공정한 법제도 마련}

초기 스튜디오 시스템은 저작권에 대한 법적 분쟁을 가져왔고 아직도 진행 중이다. 창작이라는 하나의 예술 작업을 공장처럼 분업화해놓았을 때 이에 협업한 작가간의 창 작물 권리에 대한 정확한 수익 분배가 애매해진다. 이에 미국은 1976년 저작권법 (Copyright Act)을 만들어 기본적인 틀을 확립한 이후 지금까지도 여러 차례 수정을 통해 저작권에 대한 세부사항을 보완하고 있다. 저작권 관련 법은 출판만화 시장이 안정 적인 고용과 수익 분배에 대한 공정성을 얻기 위한 필수적인 사회 제도이자 안전장치다. 
이는 대형 출판사가 작가들과 프로젝트별 단기 고용 계약을 맺고 다양한 저작권 활동을 할 수 있는 기반이 되어 왔다.

특히 물리적으로 책을 사고파는 형식이 아니라, 디지털로 작품을 서비스하는 웹툰 산 업은 출판시장과 다른 수익 구조를 갖는다. 따라서 미국에서 역량 있는 작가들이 디지털 시장에 안정적으로 유입되기 위해서는 새로운 고용 체제와 댜각화된 수익 배분에 맞는 법률 제도가 요구된다. 


\section{제4절 소결}

본 장의 시례분석을 통해 일본, 미국 등 만화산업 고도화를 이룬 선도국의 그 진화 과정과 세부 요인들을 살펴보았다. 그 결과, 제작과 유통 측면에서 다음과 같은 정책적 시사점을 파악할 수 있었다.

\section{1. 제작 측면에서의 고도화 요인}

\section{가. 폭넓은 시장층과 다양한 작품}

웹툰산업이 고도화되고 발전될수록 독자층의 범위와 폭은 넓어지고 이들이 추구하는 취향 역시 다양화된다. 만화산업 선도국인 일본은 독자의 나이, 성별, 작품의 주제 등으 로 촘촘히 세분화한 200종이 넘는 만화 잡지가 구성되어 있었다. 그만큼 폭넓은 독자층 과 다채로운 작품이 구축되어 있다는 것이다. 오랜 기간 동안 만화산업이 커가면서 다양 한 수요자층을 유입시킬 수 있는 틈새시장들이 개발되고 다양한 수요가 충족되면서 수 요와 공급이 지속적으로 늘어나는 선순환 체계가 형성되었다. 미국 역시 스튜디오화의 획일화를 극복하는 과정에서 다양한 세계관과 장르들이 형성되었다. 스튜디오화 과정에 서 대량생산 작품을 중심으로 문법에 맞는 획일화된 작품의 생산이 이루어지다 작가가 직접 아이디어와 극을 이끌게 되는 마블 메소드 방식으로의 변화가 이루어지면서 다양 한 장르와 창작세계를 나타나게 되었다. 이는 비해 우리나라는 플랫폼 주도로 빠르게 성장한 측면이 있어 제공할 수 있는 장르의 다양성이 제한적이며 윕툰의 장르가 로맨틱 판타지 장르에 치중되면서 덩치가 커지고 있는 웹툰산업에 의미하는 바가 크다. 


\section{나. 편집부(editor)의 역할 정교화}

웹툰의 기획력 강화를 위한 체계적인 전략이 필요하다. 일본 만화제작 시스템의 가장 큰 특징 중 하나는 전문 편집자가 체계적으로 양성되어 작품의 질을 높이는데 크게 기여 한다는 점이다. 일본에서 히트를 친 대부분의 작품들은 결과물이 만들어지는 과정에서 작가는 물론 편집자가 주요한 역할을 하고 있다. 편집자의 역할은 작품을 위한 자료 조 사와 사전 조사뿐 아니라 작품의 전체적인 방향성에 관한 사항까지 적극적으로 관여할 정도의 전문성을 지닌 인력이다. 이러한 편집자는 신입으로 입사할 때부터 선배 편집자 들에게 여러 가지 훈련을 거치며 체계적으로 단계를 밟아 성장한다. 한편, 미국의 편집 부는 일본과는 조금 다른 역할을 하고 있다. 일본의 편집부가 기획이나 지원 등 주변부 에서 중심의 역할을 보조하기 위한 역할을 한다면, 미국의 편집자는 전체 프로젝트를 총괄하고 관리하는 감독의 역할을 수행한다. 편집자는 프로젝트를 진행에 적합한 만화작 가들을 모아 하나의 팀을 구성하고, 팀원들 간의 원활한 소통이 될 수 있게 창구 기능을 한다. 따라서 스토리 제안, 작품의 질 관리, 마감일 준수 등 예술적인 감각과 더불어 행 정 능력까지 갖추어야 한다. 이와 같이 일본과 미국의 편집부 모델은 서로 다르지만 작 품의 질을 높이는데 시스템적으로 기여한다는 점에서 각자의 장점을 우리나라 웹툰산업 에 접목할 필요성이 있다.

\section{2. 유통 측면에서의 고도화 요인}

\section{가. 글로벌 이벤트 적극 활용}

웹툰 홍보를 위한 글로벌 마켓 등 이벤트를 확대해 나갈 필요가 있다. 일본에서는 이 미 1970년대 중반부터 만화의 창작과 소비, 유통이 프로 작가와 전문 출판사의 상업적 영역뿐 아니라 아마추어 독자들이 모여 산업과 소비를 활성화하는 코믹 마켓이 열렸다. 이는 초기에 만화 동인지 판매전으로 시작했지만 40년이 넘게 그 명맥이 유자발전되면 서 참가자 수는 50만 명 이상으로 증가해 세계 최대 규모의 만화 이벤트가 되었다. 국내 뿐 아니라 앙굴렘 만화축제 등 주요 국제 만화행사에는 일본 망가가 절반에 가까운 점유 율을 보인다. 미국의 경우에도 코미콘 등 주요 만화관련 마켓과 이벤트에 DC와 마블 
등의 주요업체가 적극적으로 참여하여 전 세계 거래처와 소비자 확대를 위한 수단으로 활용되고 있다. 이처럼 긴 역사를 가진 일본 및 미국 만화산업에 비해 우리나라 웹툰에 대한 인지도는 아직까지 낮은 편이다. 향후 웹툰에 대한 인지도를 더욱 높이고 웹툰 형 식에 대한 표준화를 지원하기 위하여 글로벌 마켓 지원을 확대하여야 한다.

\section{나. 미디어 믹스, IP 확장의 발전}

만화선도국의 가장 큰 특징 중에 하나는 정교한 미디어 믹스전략을 활용하고 있었다 는 것이다. 일본과 미국 모두 만화 콘텐츠를 만화산업 내에서만 국한하는 것이 아니라 $\mathrm{IP}$ 를 활용하여 애니메이션, 방송, 영화 등 타 장르로의 적극적으로 확장을 시도하여 부 가가치를 극대화하는 것이 일반화되어 있다. 일본은 기획단계에서부터 TV애니메이션과 드라마 제작을 염두하고 제작이 진행되기도 했으며, 일본 영화의 역대 흥행작 순위의 1 위에서 5 위까지가 애니메이션일 정도로 미디어 믹스전략이 발전되어 있다. 미국 역시 도 $\mathrm{MCU}($ Marvel Cinematic Universe)와 같이 마블과 DC를 중심으로 만화 IP를 활용 한 영화와 드라마가 크게 성공하고 있으며 전 세계적 흥행과 영향력을 발휘하고 있다. 일본과 미국 모두 만화 콘텐츠를 만화 산업 내에서만 국한하는 것이 아니라 IP를 활용하 여 애니메이션, 방송, 영화 등 타 장르로의 적극적으로 확장을 시도하여 부가가치를 극 대화하는 것이 일반화되어 있다. 일본은 기획단계에서부터 TV애니메이션과 드라마 제 작을 염두하고 제작이 진행되기도 했으며, 일본 영화의 역대 흥행작 순위의 1 위에서 5 위 까지가 애니메이션일 정도로 미디어 믹스전략이 발전되어 있다. 미국 역시도 $\mathrm{MCU}($ Marvel Cinematic Universe)와 같이 마블과 DC를 중심으로 만화 IP를 활용한 영화와 드라마가 크게 성공하고 있으며 전 세계적 흥행과 영향력을 발휘하고 있다. 
웹툰산업 해외진출 진흥 방안 연구

제5장

\section{웹툰산업 해외진출 정책 분석 및 전문가 인터뷰}





\section{제1절 웹툰산업 해외진출 정책 분석}

\section{1. 상위 계획 분석}

\section{가. 만화산업 발전 계획(2019)}

문화체육관광부는 2019년 10월 17일, 한국 만화산업의 글로벌 수준 발전을 위한 방 편으로 2023년까지의 〈만화산업 발전 계획〉을 수립하여 발표하였다. 만화분야 전문가 및 정책담당자로 구성된 민관 협의체 운영과 170 명의 만화분야 관계자 설문조사를 통해 의견을 수렴한 이 계획에서는 '꿈이 커가는 한국만화, 새로운 한류의 중심'이라는 비전 이래 산업 경쟁력 강화, 신시장 확대 및 수요 창출, 공정환경 조성 및 제도 개선 등 3 가 지의 정책 방향을 제안하였다.

이 중 웹툰 해외진출 정책과 관련된 전략 방향은 두 번째 전략방향인 신시장 확대 및 수요 창출이다. 만화를 '신한류 콘텐츠로 도약'시키기 위해 2018년에 0.4억 달러 수준 이었던 수출액을 2023년까지 1억 달러로 끌어올리는 것을 목표로 설정하였다. 또한 이 를 구체화시키기 위해〈표 5-1〉과 같이 추진전략과 추진과제들을 각각 마련하였다.

〈표 5-1〉 신시장 확대 및 수요 창출을 위한 세부 전략 방안(만화산업 발전 계획, 2019)

\section{추 진 과 제 추진 일정 \begin{tabular}{l|l|l|l|l|}
\hline 19 & 20 & $' 21$ & $' 22$ & $' 23$ \\
\hline
\end{tabular}}

\section{[전략 2] 신시장 확대 및 수요 창출}

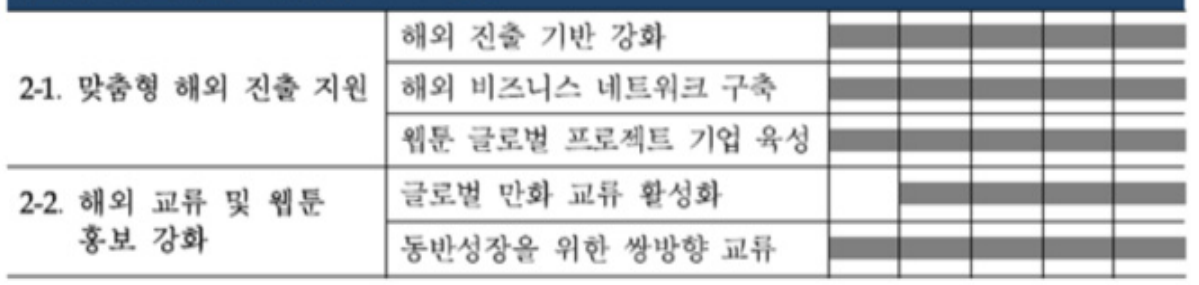


신시장 확대 및 수요창출을 위해서 구체적으로 정부에서는 맞춤형 해외 진출을 지원 하고 해외 교류 및 웹툰 홍보를 강화하는 추진 전략을 수립하였다. 먼저, 맞춤형 해외 진출의 일환으로 해외진출 상담센터를 통해 지역별 만화시장에 관한 심층 정보와 트렌 드를 분석한 자료를 제공하고 해외진출을 시도하는 사업자를 대상으로 번역을 강화하는 등 해외진출 기반을 강화하고자 하였다. 또, 해외 프로모션이나 글로벌 비즈매칭과 같이 해외 비즈니스 네트워크를 구축하는 것은 물론 해외 플랫폼 구축이나 마케팅 지원과 같 은 수출 역량 강화를 지원하는 세부방안들을 추진한다.

한편, 해외 교류와 웹툰 홍보를 강화화는 전략을 구체화하기 위해서 글로벌 만화 교류 를 활성화하고 동반 성장을 위한 쌍방향 교류 기회를 확대하는 전략과제도 동시에 발표 하였다. 글로벌 만화 교류를 활성화하기 위해 국내에서 웹툰 포럼이나 시상, IP 마켓, 작가 교류회 기능을 가진 규모 있는 글로벌 이벤트 개최를 추진하고 글로벌 네트워크를 구축하고자 한다. 또, 해외 현지에 웹툰 전파를 위한 해외 웹툰 창작체험관이나 작가 교 류프로그램을 진행하여 해외 현지에서의 홍보와 협업을 강화할 방침이다.

\section{2. 주요기관 웹툰산업 해외지원 사업 현황}

\section{가. 한국콘텐츠진흥원}

1) 만화 IP 해외 피칭 지원

웹툰 IP를 보유하고 있는 플랫폼 및 에이전시를 대상으로 조사한 〈2020 웹툰 사업체 실태조사 보고서>에 따르면, 해외 비즈니스를 위해 '해외 바이어/유통사와의 네트워크 구축’이 59.5\%로 가장 필요하다고 나타났으며, ‘해외시장 조사 및 시장 정보'가 $47.6 \%$, '통역 및 번역 지원'이 35.7\%, ‘해외 마케팅 전문 인력 양성 및 지원'이 23.8\%순으로 조사되었다. 이를 바탕으로 현재는 한국 만화 IP의 해외 진출 계획이 있는 개인 및 법인 을 대상으로 해외마켓 참가, B2B 중심의 피칭, $1: 1$ 비즈니스 상담 등 해외 바이어들과의 네트워크 구축을 목적으로 해외 수출 지원사업의 범위를 확대하여 진행하고 있다.

해외 피칭 지원 사업은 한국만화 IP를 보유하고 있는 개인 및 법인에게 해외 제작사와 투자사, 바이어들에게 해외 진출에 대해 논의하며 웹툰 콘텐츠 투자 유치 및 공동제작, 
판매 등 투자의 장을 마련해주는 사업으로, 중국의 베이징, 일본의 도쿄, 프랑스 파리, 미국 LA 총 4 개국에 행사 별 10 개사 내외로 지원하며 통번역 지원은 물론, 피칭 자료 및 홍보영상 제작과 현지 시장 정보를 파악할 수 있는 트렌드 교육까지 지원한다. 또한 피칭 이후 비즈니스 계약 체결 시 관련 법률 자문 등 사후 지원까지 이루어진다.

실제로〈K-Story \& Webtoon in Japan〉, 〈K-Story \& Comics in China〉, 〈K-Story·Comics \& Characters in America〉과 같이 일본과 중국, 미국 시장 등 웹툰 콘텐츠 경쟁력이 높은 국가들을 타겟으로 한국과 해당 국가의 웹툰 IP 공동 포럼, 멘토링 프로그램 등 국내 스토리 및 만화 콘텐츠의 해외 피칭, 비즈매칭 프로그램을 해마다 운영 중이며, 해외진출 가능성이 높은 스토리 IP를 보유한 사업자들이 꾸준히 지원하고 있다.

[그림 5-1] 2018년 일본에서 진행된 K-Story \& Webtoon in Japan에서 일본 현지 바이어와 상담하고 있는 국내 관계자들62)

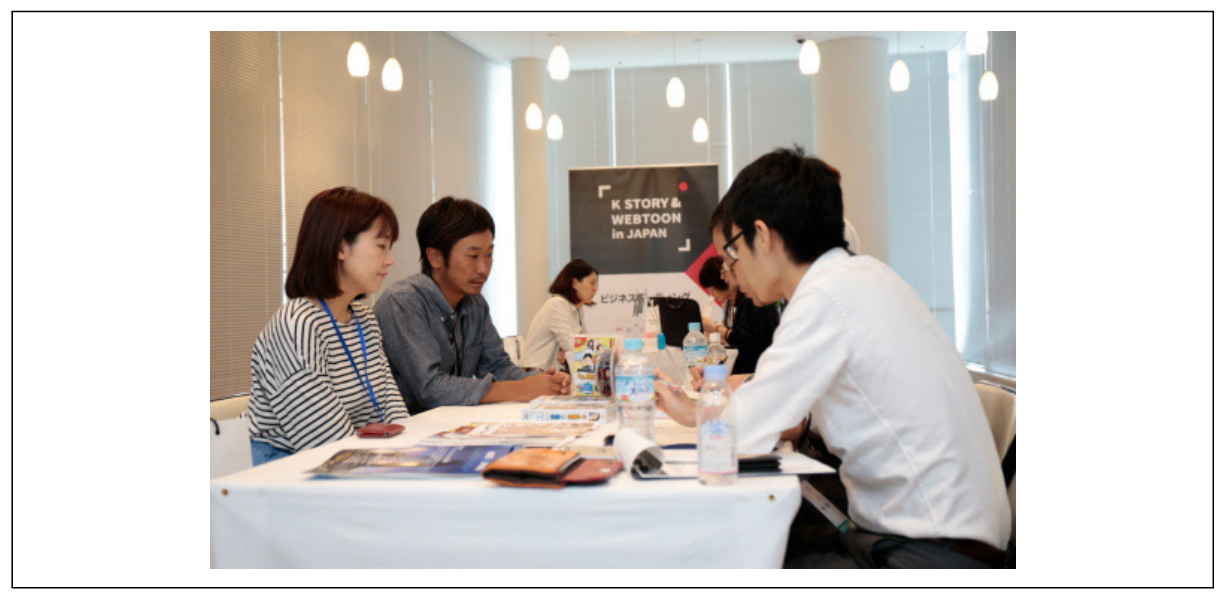

또한 2020년부터 한국콘텐츠진흥원은 한국무역협회과 함께〈KOCCA-KITA 공동 $\mathrm{K}$-콘텐츠 화상 수출상담회>를 개최해 한국 콘텐츠와 관련 제작사, 유통사 등 해외진출 을 원하는 업체를 대상으로 수출상담회를 진행하고 있다. 만화산업을 포함해 게임, 캐릭 터, 실감콘텐츠 등 다양한 장르의 해외 수출을 지원하는 이 사업은 온라인 화상 상담회 참가 및 화상 상담장을 제공하고 있으며, 비즈니스 미팅을 위한 통역 지원은 물론, 사전 비즈매칭 및 바이어 정보 제공, 사후관리까지 지원하고 있다.

62) 디지털타임스, 국내 우수 스토리·웹툰 일본진출 (2018.06) 


\section{2) 기업 자율형 만화 해외 프로모션 지원}

한국콘텐츠진흥원은 위와 같이 해외 바이어들과의 네트워크 구축을 목적으로 만화 해 외 피칭 지원과 동시에 해외 프로모션도 지원하고 있다. 특히 해외 프로모션 지원 사업 은 한국 만화 콘텐츠의 해외 진출을 촉진하기 위해 진출하고자 하는 국가의 맞춤형 프로 모션을 지원한다. 본 지원 사업은 만화의 해외 진출을 위한 자율형 지원 사업으로, 웹툰 을 포함한 한국 만화 IP의 해외 진출 계획을 가지고 있는 사업자를 대상으로 진행되며 구체적으로 해외 마켓 참가부터 쇼케이스, 프로모션 개최 등 수출 활동 지원과 해외 행 사 개최 비용 등 전반적인 제반 비용을 지원하고 있다.

2019년 총 6개 내외 프로젝트 당 최대 지원금 총 4,500만 원 지원을 시작으로 2021 년 현재 최대 8 개사 내외 프로젝트 당 최대 지원금 5,000 만 원으로 그 지원 규모가 점차 확대되고 있다.

[그림 5-2] 2018년 중국 제 25회 베이징국제도서전에서 진행된 만화·웹툰 작가 시연회63)

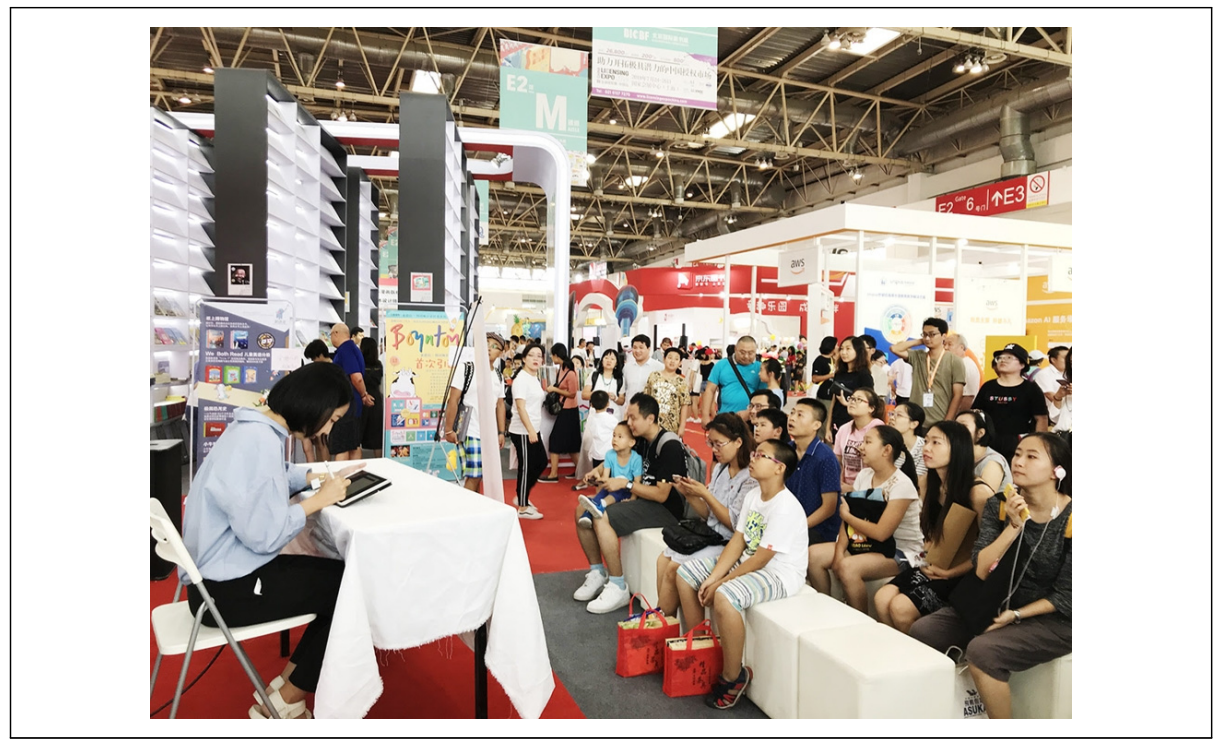

만화 해외 프로모션 지원 사업 중 하나인 해외마켓 참가 지원은 2021년 현재 북미 또는 유럽 등 콘텐츠 성숙시장의 마켓을 중심으로 10 개사 내외를 선정하여 지원한다. 이러한 해외마켓 참가를 통해 비즈니스 미팅을 위한 장소 제공과 더불어 각 사가 보유하

63) 데일리굿뉴스, 한국 만화·웹툰 중국 사로잡아 (2018.08) 
고 있는 콘텐츠 IP를 홍보할 수 있도록 전시 지원, 통역 지원, 이벤트 개최 등 한국 만화 $\mathrm{IP}$ 의 해외 진출을 위해 온오프라인 채널을 모두 활용하여 행사를 개최하고 있다.

\section{3) 만화 해외 플랫폼 구축 및 운영 지원}

한국콘텐츠진흥원에서는 웹툰 콘텐츠의 해외 진출을 견인할 플랫폼의 중요성을 강조 하며 한국 만화의 해외 진출을 이끌어갈 플랫폼 기업 발굴하고 육성함으로써 글로벌 만 화 시장 선점을 목표로 만화 해외 플랫폼 구축 민 운영 지원 사업을 실시하고 있다. 주된 지원 내용은 5 개 내외 과제를 선정해 3억 원 규모로 해외 플랫폼 구축 운영비, 마케팅비, 콘텐츠 수급비 등 재정적 지원이 주를 이루고 있으며, 인도네시아, 베트남, 태국 등 진출 하고자 하는 해외 시장에 만화 플랫폼을 신규로 구축할 계획이 있거나 운영 중인 대한민 국 법인 사업자를 중심으로 지원하고 있다. 또한 선정된 업체마다 KOTRA 해외 진출 토탈 패키지를 추가로 지원하며 KOTRA를 통해 해외사업비 사전 검토 및 집행과 관련 한 전반적인 관리를 받게 된다. 현재 만화 해외 플랫폼 구축 지원 사업은 2019년 3월 8일 이후 해외 현지 서비스가 상용화된 플랫폼도 대상자로 포함해 신규 구축으로 지원이 가능하다.

\section{4) 만화 해외마켓 한국공동관 참가 지원}

본 사업은 북미 또는 유럽 등 콘텐츠 성숙시장에서 열리는 해외의 주요 마켓에 한국공 동관을 열어 해외마켓 참가를 통해 해외 수출을 촉진하고자 하는 사업이다. 세부적으로 는 해외 마켓 한국공동관 내 수출상담회 및 콘텐츠 전시, 이벤트 지원을 비롯해서 주요 작품의 피칭과 비즈매칭까지 지원하고 있다. 또한 만화시장 이야기산업 활성화나 신흥시 장개척지원 사업 등 한국콘텐츠진흥원에서 진행하고 있는 연관성이 높은 사업들과도 연 계하여 행사를 운영하고 있기도 하다. 해당 시장에서 한국만화 IP를 보유하고 있는 사업 자나 창작자를 대상으로 지원을하고 있으며 행사별로 10 개사 내외를 선발하여 8 억 규모 의 예산을 활용하고 있다. 


\section{나. 한국만화영상진흥원}

\section{1) 수출작품 번역 지원}

한국만화영상진흥원은 다양한 해외 진출 지원 사업 중 수출작품 번역 지원 사업을 중점적 으로 운영하고 있다. 본 지원 사업은 우수한 만화 IP의 해외 수출 활성화를 위해 번역 및 과제 당 850만 원 1천만 원 내외로 재제작 비용을 지원하고 있으며, 출판사, 에이전시, 윕툰 플랫 폼, 만화작가 등 한국만화 수출을 계획하고 있는 사업자를 대상으로 운영되고 있다. 2016년 총 20종 내외 지원 규모로 시작된 번역 지원 사업은 2021년 현재 55개 내외의 지원으로 그 규모가 점차 확대되고 있으며, 한국외국어대학교, 이화여자대학교 통역번역연구소 등 번역 전 문 기관과의 협업을 통해 번역 결과물의 질적 수준을 점점 향상시키고 있다.

2017년 지원작 〈왕의 딸로 태어났다고 합니다〉는 중국과 일본, 프랑스, 미국 베트남 등에서 연재하며, 중국의 큐큐닷컴과 베트남의 코미콜라에서 유료 웹툰 1 위를 달성했다. 또한 2018년 이나래 작가의 〈허니블러드)가 수출 번역 지원을 통해 중국, 일본, 북미, 프랑스, 인도네시아 등 해외 10 여 개국에서 연재되었으며, 중국 플랫폼 '콰이칸'에서 500억 뷰를 달성하기도 했다. 2018년 또 다른 지원작 정지훈작가의 〈모기전쟁〉은 중국, 일본, 태국, 인도 등 해외 5개국에서 연재되었다.64) 2020년에는 수출작품 번역 지원사 업 선정작 〈전지적 짝사랑 시점〉이 선정되며 중국어 번역 지원을 받았다.

[그림 5-3] 2020년 수출작품 번역 지원사업 선정작 〈전지적 짝사랑 시점〉65)

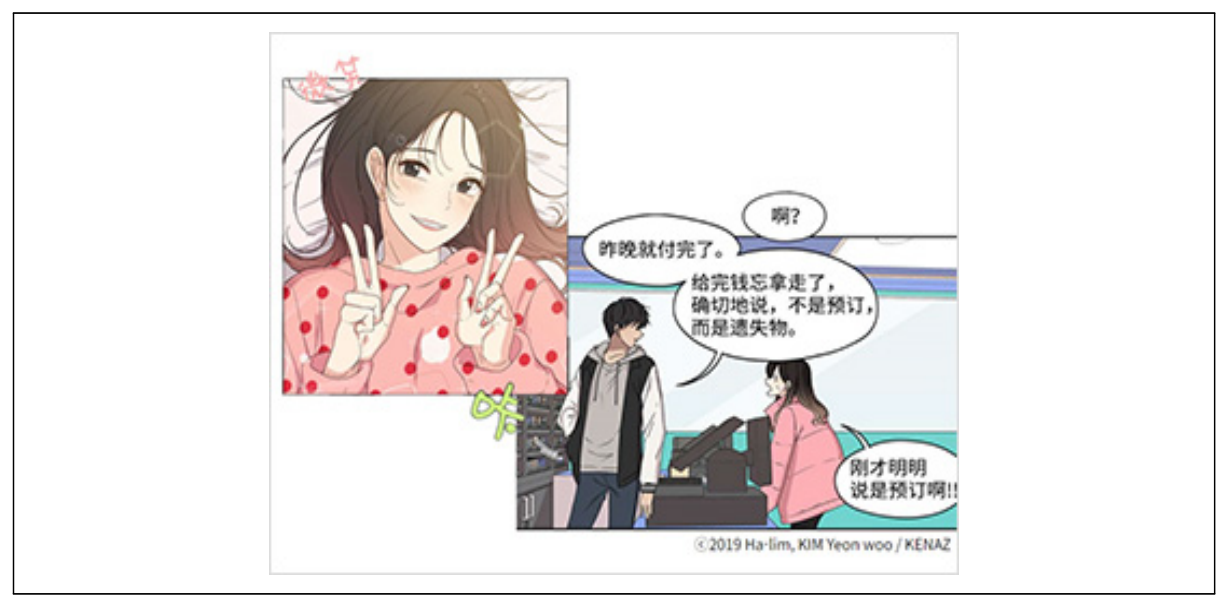

64) 아이티비즈, 한국만화영상진흥원, 만화 콘텐츠 해외 진출 지원사업 공모 (2020.06)

65) 한국만화영상진흥원 해외수출지원 (http://wnw.komacon.kr/komacon/business/cluster.asp) 


\section{2) 한국만화 해외전시 및 만화 교류 지원 사업}

2019년부터 진행되고 있는 해외 만화전시 및 만화 교류 지원 사업은 한국의 대표 콘 텐츠로 자리잡은 웹툰의 글로벌 인지도 및 해외 소비자 확대를 목적으로 개최되는 문화 행사 중 하나이다. 또한 세계웹툰포럼과 같은 글로벌 웹툰 시장 동향과 미래 전망을 분 석하고, 각국의 만화계와 소통하는 일종의 협력 창구 목적으로 운영되며, 해외문화원과 연계한 만화 전시 개최를 통해 한국 만화와 웹툰의 브랜드 가치를 높이는 활동을 하고 있다. 해외 만화전시를 개최하고자 하는 만화작가나 전시기획자, 단체 및 기관을 대상으 로 최대 3 4개의 전시를 지원하며 전시 당 1 천만 원 4천만 원 내 차등 지원한다.

2019년에는 이탈리아 만화축제와 연계한 '윕툰의 세계로 초대합니다 (BENVENUTI NEI MONDO DEL WEBTOON)' 만화 전시 개막식에 직접 참여했으나, 2020년은 코로 나 19로 인해 아랍, 영국, 프랑스 3국의 웹사이트를 통해 'K-Comics in my life(나의 인생 한국 만화)'라는 주제로 해외문화원 연계 만화전시를 진행하게 되었다. VR 콘텐츠 제작, 유튜브 체널을 통한 드로잉쇼, 영국의 아시아만화 평론가인 폴그라빗과 강도하 작가 의 대담회 외 유튜브 클립 콘텐츠들을 공개하며 온라인 중심으로 행사를 진행했다.66)

[그림 5-4] 2019년 이탈리아 '웹툰의 세계로 초대합니다(BENVENUTI NEL MONDO DEL WEBTOON)' 만화 전시 개막식67)

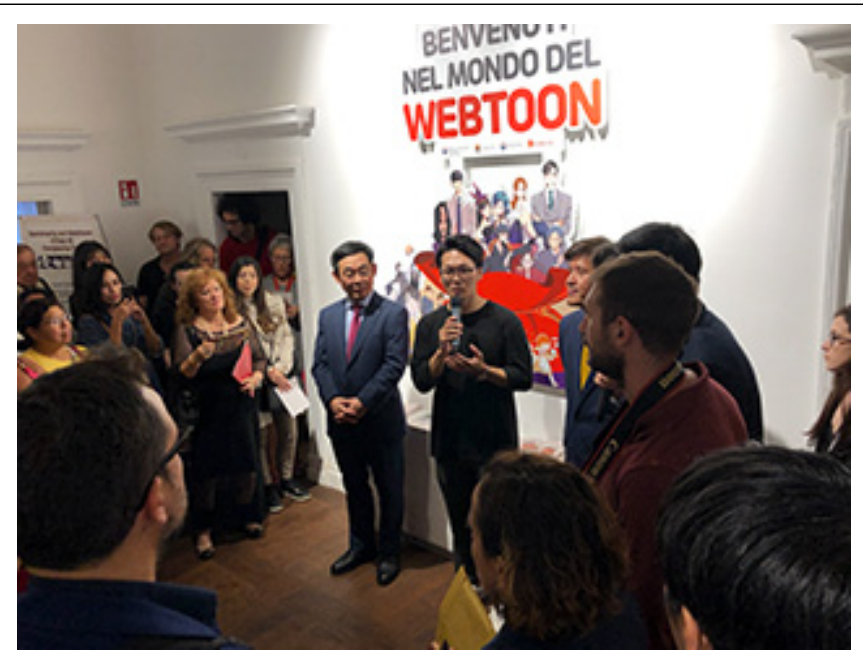

66) 아이티비즈, 한국만화영상진흥원, '2020 해외문화원 연계 만화전시' 열어 (2020.11)

67) 한국만화영상진흥원 해외수출지원 (http://www.komacon.kr/komacon/business/cluster.asp) 


\section{3) 해외 프로모션 지원 사업}

2020년 코로나19 이슈로 인해 국내·외 수출 상담회 및 박람회 등 대면 지원 사업의 개최가 어려워지면서 비대면 해외 마케팅 컨설팅을 통해 중소 만화 콘텐츠 기업을 지원 하고자 해외 프로모션 지원 사업을 시행하게 된다. 출판사, 에이전시, 웹툰 플랫폼, 만화 작가 등 수출을 계획하는 사업자를 대상으로 한 이 지원 사업은 한국만화(웹툰) IP를 활 용한 영상 제작 지원은 물론, 작품을 소재로 한 책자, 굿즈 등과 같은 홍보물 제작 지원, 번역비 등 해외 마케팅에 필요한 전반적인 프로모션 활동을 지원하며 선정 기업 당 최대 3천만원 규모로 진행된다.

2021년 현재 문화콘텐츠 전문제작기획사 락킨코리아가 본 지원사업을 통해 나예리 작 가의 〈피터판다〉, 원수연 작가의 〈풀하우스〉, 오경아 작가의 〈거울의 숲〉, 노이정 작가의 〈여왕님의 사랑〉, 이해 작가의 〈루르빌〉 등 다양한 작품들의 해외 수출을 확정했다.68)

[그림 5-5] 해외 프로모션 지원사업을 통해 해외 수출을 확정지은 락킨코리아의 웹툰 IP69)

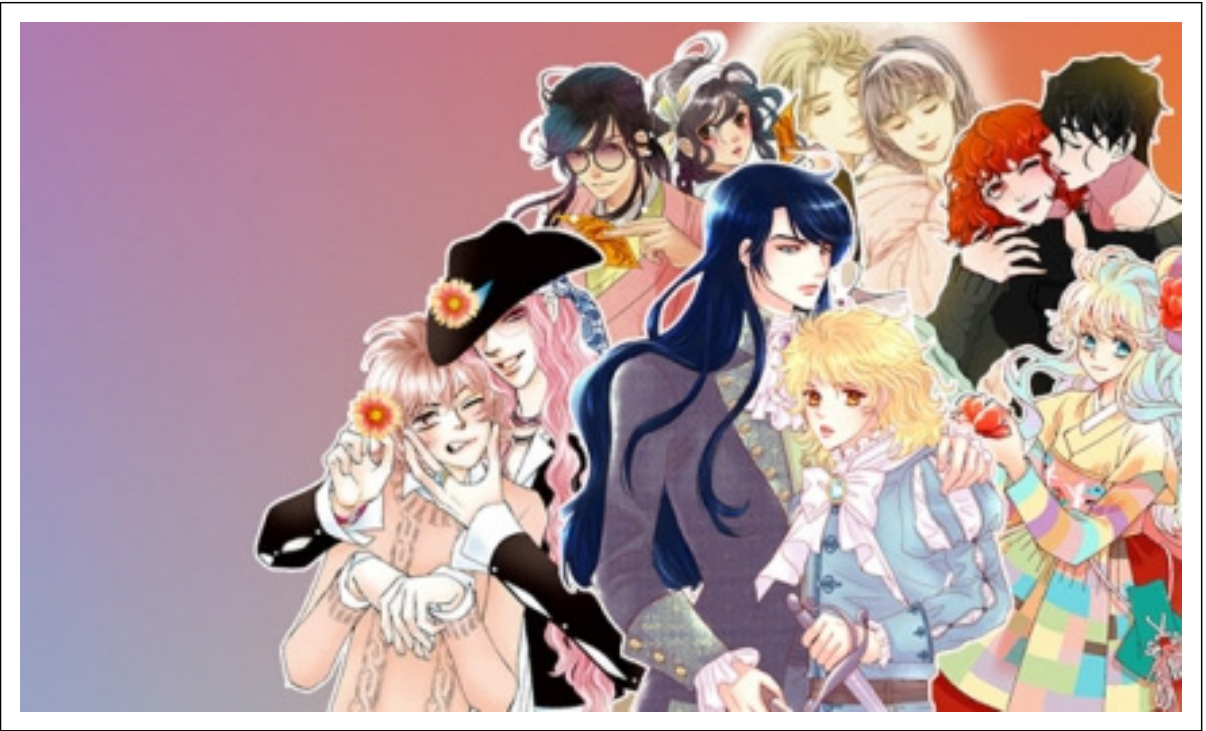

68) 이데일리, '풀하우스' 원작 만화, 웹툰 재탄생...20여 개 K-웹툰 해외 수출 (2021.01)

69) 스타데일리뉴스, 락킨코리아, 20여 개 국내 웹툰 수출 확정 'K-웹툰 전 세계에 알린다!' (2021.01) 


\section{다. 기타 기관}

1) 경기콘텐츠진흥원(GCA)의 웹툰 해외 수출 지원 사업

주요 콘텐츠 사업 기관 중 하나인 경기콘텐츠진흥원도 웹툰을 포함한 한국 만화 콘텐 츠의 해외 수출 지원 사업을 운영하고 있다.

2017년 경기콘텐츠진흥원과 서울산업진흥원, 대한무역투자진흥공사와 함께 웹툰 콘 텐츠의 중국 진출을 위한 수출 판로 개척 및 중국 바이어 네트워크 구축을 목적으로 중국 광저우와 베이징에서 〈2017 한중 애니메이션·웹툰 비즈니스 상담회〉를 개최하며 해외 진출 지원 사업을 본격적으로 시작한다. 1:1 매칭 방식의 비즈니스 상담회로 이루어진 본 지원사업은 2018년부터 한국만화영상진흥원, 대한무역투자진흥공사(KOTRA)과 함 께 지원 사업을 진행하며 상하이, 광저우, 칭다오 등 다양한 지역의 바이어를 유치하며 총 660건의 상담을 진행, 수출 계약 추진액 약 890억 원을 달성하게 된다.70) 또한 2019 년 경기도 소재 애니메이션 콘텐츠 기업(제작사, 에이전시, 배급사)을 대상으로 중국 현지 에서 〈한중 애니메이션-웹툰 비즈니스 상담회〉를 실시하며, 수출상담회 공간 및 중국 바 이어와의 $1: 1$ 비즈니스 상담 매칭, 통역, 브로셔 제작과 같은 홍보 활동을 지원한다.

또한 킨텍스와 함께〈2019 경기국제웹툰페어〉를 개최, B2B 프로그램을 통해 국내 웹툰 관련 기업들을 대상으로 국내 및 해외 바이어와 $1: 1$ 비즈니스 매칭 및 바이어 정보 공유를 통한 네트워크 지원, 통역과 상담 공간은 물론, 미팅을 희망하는 해외 바이어의 왕복 항공권과 숙박권까지 지원한다.

이처럼 경기콘텐츠진흥원은 수출 상담회 형식의 해외 바이어 매칭을 통해 해외 수출 지원 사업을 이어가고 있다.

\section{2) 대한무역투자진흥공사(KOTRA)의 웹툰 해외 수출 지원 사업}

중소-중견기업의 해외시장 진출 및 무역투자 진흥 사업을 주관하고 있는 대한무역투 자진흥공사(이하 코트라)는 2021년 처음으로 한국만화영상진흥원과 함께 수출 상담회 형식의 〈웹툰 글로벌 유통망 진출지원 사업 (Webtoon Plaza)〉을 개최한다. 온라인 1:1 상담회로 진행되는 본 사업은 코트라가 모집한 해외 주요 디지털코믹스 바이어와 해외

70) 서울경제, 한국만화영상진흥원, 25 조원 중국 애니메이션 웹툰 시장 지원 사격 (2018.06) 
진출을 희망하는 국내 웹툰 기업 간의 온라인 상담 및 해외 바이어를 대상으로 피칭을 희망하는 기업을 선정하여 온라인 피칭 세미나를 지원하는 웹툰 IP 피칭 세미나 개최가 주된 지원 내용이다.

총 20 개의 국내 웹툰사가 참여하고 중국. 일본 등 11 개국 63 개 해외 바이어 참가한 본 사업은 해외 바이어의 국내 작품에 대한 이해도를 높이기 위해 프리뷰 형식으로 세미 나를 개최했으며, 국내 기업의 웹툰 IP를 소재로 동영상을 제작해 해외 바이어들에게 흥미로운 방법으로 작품을 소개했다.71) 이처럼 해외 바이어 제공을 위한 기업별 홍보 영상 제작 지원 및 해외 바이어 언어별 전담 통역지원, 해외 콘텐츠 크리에이터를 활용 해 콘텐츠 리뷰 제작과 SNS 홍보까지 지원하며 신선한 방법으로 해외시장 진출을 추진 하고 있다.

\section{3. 웹툰산업 해외진출 지원 관련 사업 정리}

각 기관별 웹툰산업 해외진출 지원 사업들을 정리해보면 지원 기능 중 홍보와 프로모 션 관련 사업이 가장 많은 것으로 나타났다. 이들은 대부분 해외의 마켓이나 쇼케이스에 한국관 등을 만들어 홍보와 네트워킹할 수 있는 자리를 마련하거나 바이어에게 피칭을 하거나 상담회를 할 수 있는 기회를 마련해주는 지원들이다. 이는 한국콘텐츠진흥원, 한 국만화영상진흥원, 경기콘텐츠진흥원, KOTRA 등 다양한 기관에서 비슷한 내용을 진행 하고 있으며 서로 간 협력을 통해 공동개최하는 경우도 많다. 이들은 해외진출에 있어서 가장 즉시적이고 직접적인 효과를 창출할 수 있는 수단들이다.

번역 지원 사업의 경우에는 한국콘텐츠진흥원에도 만화 해외번역 지원사업이 있었지 만 현재는 한국만화영상진흥원에서만 지원하고 있다. 다만, 그 지원 규모가 6억 원 수준 으로 현재 더 높아진 지원수요를 고려할 때 규모를 더 확장할 필요가 있다.

71) 뉴시스, K웹툰, 세계로 ․ㅋ크트라 24일부터 온라인상담회 (2021.05) 
〈표 5-2〉 각 기관별 웹툰산업 해외진출 지원 사업

\begin{tabular}{|c|c|c|c|}
\hline 기능 & 사업명 & 사업수행기관 & 지원 규모 \\
\hline \multirow{4}{*}{$\begin{array}{l}\text { 홍보, } \\
\text { 프로모션 }\end{array}$} & 만화 IP 해외 피칭 지원 & 한국콘텐츠진흥원 & 6.8 억, 행사별 10 개사 \\
\hline & $\begin{array}{c}\text { 기업 자율형 만화 해외 프로모션 } \\
\text { 지원 }\end{array}$ & 한국콘텐츠진흥원 & $\begin{array}{l}\text { 4억, 총 8개사 } \\
\text { (기업당 5천만원) }\end{array}$ \\
\hline & $\begin{array}{c}\text { 만화 해외마켓 한국공동관 참가 } \\
\text { 지원 }\end{array}$ & 한국콘텐츠진흥원 & 3.5억, 10개사 내외 \\
\hline & 해외 프로모션 지원 사업 & 한국만화영상진흥원 & $\begin{array}{c}3.6 \text { 억원, } \\
\text { 프로모션 9개 과제, 상담회 } 12 \text { 개사 }\end{array}$ \\
\hline 번역 & 수출작품번역지원 & 한국만화영상진흥원 & 6억, 70개과제(과제당 850만원) \\
\hline $\begin{array}{c}\text { 플랫폼 } \\
\text { 구축/운영 } \\
\text { 지원 }\end{array}$ & $\begin{array}{c}\text { 만화 해외 플랫폼 구축 } \\
\text { 및 운영 지원 }\end{array}$ & 한국콘텐츠진흥원 & 최대 3억원, 4개 내외 과제 \\
\hline $\begin{array}{l}\text { 국제 } \\
\text { 교류 }\end{array}$ & $\begin{array}{c}\text { 한국만화 해외전시 및 } \\
\text { 만화 교류 }\end{array}$ & 한국만화영상진흥원 & 3.7억 \\
\hline
\end{tabular}




\section{제2절 전문가 및 업계 의견 조사}

\section{1. 전문가 및 업계 관계자 자문회의 개요}

실질적이고 구체적인 해외진출 진흥 방안을 도출하기 위해 전문가 및 업계 관계자 자 문회의를 진행하였다. 자문회의에서는 웹툰 해외진출 현황과 문제점에 관련한 질문을 중 심으로 개인별 심층인터뷰의 방식으로 이루어졌다.

〈표 5-3〉 전문가 및 업계 관계자 명단

\begin{tabular}{|c|c|}
\hline 구분 & 인터뷰 대상 \\
\hline 산 & $\begin{array}{l}\text { - A(웹툰 작가) } \\
\text { - B(웹툰 에이전시 b사 대표) } \\
\text { - C(웹툰 에이전시 c사 팀장) } \\
\text { - D(웹툰 플랫폼 d팀장) } \\
\text { - } \mathrm{E} \text { (웹툰 플랫폼 e실장) } \\
\text { - F(웹툰 플랫폼 f대표) }\end{array}$ \\
\hline 학 & $\begin{array}{l}\text { - G(g대학교 만화애니메이션학과 교수) } \\
\text { - H(h대학교 웹툰애니매이션학과 교수 } \\
\text { - I(i대학교 만화애니메이션학과 교수 }\end{array}$ \\
\hline 연관 & $\begin{array}{l}\text { - J(j진흥원 실장 }) \\
\text { - K(k협회 사무국장 })\end{array}$ \\
\hline
\end{tabular}

전체 기간은 2021년 4월 20일에서 2020년 7월 30일까지 3개월 동안이었으며, 10 차 에 걸쳐 다양한 대상에게 심층적 내용을 도출하였다. 구체적으로 인터뷰 대상은 웹툰 업계전문가(플랫폼, 에이전시, 스튜디오 등), 웹툰 작가, 웹툰 관련 학계 전문가, 연구계 및 관계 전문가(한국콘텐츠진흥원, 한국만화영상진흥원 등 웹툰 해외진출 사업 담당자, 협회) 등 전체 23 명이었다.

품질 높은 결과물을 도출하기 위해 구조화된 질문지 또는 회의 안건 제시를 통한 토론 을 진행하였고, 코로나 19 상황을 고려하여 온라인 원격회의와 현장회의 병행하여 이루 
어졌다. 자문회의 주요 내용은 회의 전에 인터뷰 대상자에게 미리 제공하였고, 웹툰해외 진출 주요 이슈와 트렌드, 웹툰 해외진출의 특성 및 시행착오, 웹툰 해외진출 지원의 정 책적 한계와 개선점, 해외진출 시 문제점, 해외진출 진흥방안 등에 대해 현장에서 답을 듣고 이를 정리하였다.

\section{2. 전문가 및 업계 관계자 자문회의 결과}

\section{가. 현재 웹툰의 해외진출은 도입기 단계에 불과}

전문가 및 업계 관계자 인터뷰에서 웹툰이 타 콘텐츠 장르와 가장 차별화되는 지점 중 하나는 국내에서 처음 만들어진 장르이며, 국내 플랫폼들이 전 세계 시장을 주도하고 있다는 것이며, 현재는 해외진출에 있어서 초기단계에 불과하다는 의견이 주를 이륐다.

웹툰은 국내에서 새로운 제작과 유통체계로 처음 시도되어 장르가 개척되었으며 새로 운 콘텐츠 형식과 플랫폼을 주도하여 2010년대 중반부터 해외에 진출을 적극 시도하고 있다. 그동안 한국의 콘텐츠 산업의 대부분 장르들은 넷플릭스, 유튜브, 스포티파이 등 해외에서 만들어놓은 플랫폼에 의지하여 해외에 진출하던 소극적인 방식이었다. 하지만, 웹툰은 글로벌 플랫폼과 표준 자체를 콘텐츠와 함께 진출하는 이전에는 없었던 수출방 식이 이루어지고 있다. 따라서 시작단계에서부터 지금까지 해외진출에 있어서 시행착오 를 겪고 있고 그 인지도와 충성도를 형성시키는 노력부터 시작해야하는 조금 다른 차원 의 해외진출 노력이 요구되고 있다.

이러한 측면에서 웹툰은 나아가야 할 길이 멀다고 전문가들은 의견을 피력하였다. 세계 만화시장에서 아직도 웹툰은 변방의 디지털 만화의 한 형식이며 해외시장에서 수익이 직 접적으로 발생되고 있는 곳은 한국과 일본 정도에 불과하다는 것이다. 앱 시장에서만 볼 때에는 한국의 웹툰 플랫폼이 전 세계에서 만화부문 1 위를 차지하고 점유율을 높이며 선 전 중이지만 만화 시장 전체로 넓혀서 보면 웹툰은 전세계 만화 규모에 비해 아직 낮은 수준의 점유율을 가지고 있다. 게다가, 무료로 제공하고 있는 방식이 대다수이다 보니 아 직 수익화 되기까지는 많은 과정이 필요하며, 현재는 수익화 전에 웹툰 형식을 알리고 많 이 활용할 수 있도록 하는 홍보가 필요한 단계를 거치고 있다. 마치 국내에서 포털을 중심 으로 무료로 배포됨을 통해 웹툰의 형식에 익숙해졌듯이 해외에서도 웹툰 형식에 익숙해 
지고 그 브랜드를 아는데 시간이 필요할 것으로 전문가들은 예상하였다.

"언론 상에서 기사를 접하면 최근 들어 포털을 중심으로 해의 앱시장에서의 유의미 한 성과를 두고 마치 세계 만화시장을 주도한 것처럼 느껴지지만 사실 웹툰은 수익성 차원에서나 인지도 차원에서는 넘어야할 산이 많은 단계이다. 유망성과 성장성은 매 우 뛰어나지만 냉정하게 말해서 해외시장진출에 있어서는 도입기에 불과하다."

\section{나. 중소 웹툰 전문 플랫폼사들의 해외에서의 선전과 유동적 시장 상황}

전문가 및 업계 의견에서는 해외 시장에서는 현재 포털 뿐 아니라 스타트업 사업자들 도 웹툰의 해외진출이 활발하며 유의미한 성과들이 다수 나타나고 있다고 시장을 파악 하고 있었다. 특히 세계 2 위의 만화국인 미국에서도 네이버 웹툰이나 타파스 미디어를 제외하고도 리디의 만타, 태피툰, 포켓코믹스, 투믹스 등 다양한 플랫폼이 진출하여 앱 시장 상위권을 장악 중이며, 특히 리디 만타는 구독형 모델이라는 혁신적인 모델을 가지 고 2021년 5월 기준 미국 만화 앱시장에서 1 위를 차지할 정도로 유의미한 성과가 나타 나고 있다는 것이다. 게다가 미국 뿐 아니라 다수의 유럽과 아시아의 다양한 국가에서 중소 웹툰 전문 플랫폼들이 수익을 창출하는 등 해외의 디지털 만화의 수요가 폭발적으 로 늘어나고 있는 상황과 맞물리면서 향후 웹툰산업이 전 세계에서 급성장할 것으로 예 상하였다.

"이전에는 웹툰 산업이 매년 바껀다고 표현했지만, 요즘은 하루가 다르다고 표현할 정도로 시장상황이 유동적이다. 특히, 미국이나 유럽 등 전 세계에서 디지털 만화의 수요는 높은데, 현지 출판만화 업계에서는 뻐른 변환이 이루어지지 않아 윕툰은 그 공백을 채울 수 있는 매우 큰 기회를 가지고 있다. 대규모 포털사 뿐 아니라 다양한 중소 윕툰 전문플랫폼들에게도 해외에 진출할 수 있는 여력과 기회가 확장되고 있 는 상황이다. 이 때문에 각 나라마다 시장 강자가 하루가 다르게 변하고 있는 이전 에 없던 해외시장 경쟁이 활발하다."

\section{다. 해외정보의 절대적 부족}

웹툰 해외진출을 시도하고 있는 플랫폼사들에서는 해외진출 시 해당 현지의 정보가 
부족하는 것을 해외진출 시 가장 큰 애로사항으로 뽑았다. 중소 플랫폼 뿐 아니라 후발 주자로 진입한 대규모 사업자들도 해외현지에 진출할 경우 현지의 시장상황에 이해가 필수적이지만, 세부적인 정보를 습득하기 어렵다는 것이었다.

해외 현지의 문화, 종교, 관습 등 조심해야할 리스크를 줄이고, 현지 수요에 최적화된 콘텐츠 전략을 수립해야 실패가능성을 낮출 수 있는 만큼 그 중요도는 매우 높다. 하지 만, 직접 그 시장에 부딪혀보거나 지인을 통한 정보획득 외에는 현지의 만화시장정보를 알 수 없어 정보의 한계에 부딪힐 경우가 많다는 의견이 주를 이륐다. 한국콘텐츠진흥원 의 해외현황 자료 등 일부 현지 만화시장에 대한 정보가 생산되고는 있으나 그 주기가 일정하지 않고 내용도 산발적이라는 평가도 있었다. 실제 비즈니스에서 활용되는 정보들 은 트렌드에 매우 민감하여 최신 정보가 필요하며 그 정보의 정확도가 사업의 성공을 가르기도 하기 때문에 실시간 정보를 제공해주는 역할의 요구가 있었다.

“미국이나 일본과 같이 이미 시장경쟁이 활발한 국가의 공략도 중요하지만 만화 시 장 크기에 비해 디지털화가 낮은 국가의 공략도 해외진출에 있어서 주요한 전략이 다. 하지만, 현지 디지털 만화 시장 정보를 파악하는 것은 많은 비용이 들고 정확하 지 않을 때가 많다. 윕툰도 다른 해외진출과 마찬가지로 해외시장 정보는 가장 기초 이면서 필수적인 요소이다."

\section{라. 웹툰 브랜드의 글로벌 확장과 국제 표준화 시도 필요}

인터뷰에서는 해외에서 파트너를 구하거나 계약을 진행할 때 가장 힘든 시행착오 중 에 하나는 웹툰의 인지도가 낮아 웹툰 자체를 설명하는 것이라는 의견들이 있었다. 즉, 윕툰은 세로스크롤 형식과 짧은 주기 등 다른 디지털 만화와 차별화된 독특한 요소들을 지녀 익숙해지는 데 상대적으로 시간이 걸리기 때문에 웹툰을 브랜드화하여 해외에 홍 보하고 다양한 나라에 노출될 수 있는 정부차원의 노력이 필요하다는 것이다.

"해외 진출에 있어서 가장 큰 애로사항은 윕툰을 설명할 때이다. 어느 사이트에 들 어가서 직접 웹툰을 보라고 하거나, 회사 설명자료에서 꼭 웹툰이 무엇인지 설명을 해야 한다. 따라서 윕툰을 직관적으로 설명한 사이트를 개설하여 공신력 있는 윕툰 관련 정보를 수록하면 해외진출에 있어서 효과적일 것으로 생각한다. ... 또한 윕툰 브랜드를 홍보하기 위한 대형 행사 지원도 필요하다. 앙굴렘 등 대형 만화 행사의 
대부분을 망가가 지배하고 있다. 아직 마이너한 장르인 윕툰이 알려지기 위해 적극 적인 홍보 지원이 필요하다"

또한 웹툰이 전 세계적인 디지털 만화로 자리 잡기 위해 필요한 기반 요소 중 하나가 규격과 표준을 일원화하는 것이 필요하다는 의견들도 있었다. 웹툰원본파일, 웹툰서비스 파일, 웹툰메타데이터 등 작성 원칙과 제출 기준이 경쟁사마다 서로 다를 경우 제작입장 에서는 시행착오가 생기기 때문에 웹툰으로 접근하기 어려운 요소가 될 수 있다는 것이 다. 이를 해결하기 위해 정부차원에서 글로벌 관점에서 국제표준화를 이끌어 줄 것으로 요구하였다.

"국내 윕툰의 해외 진출 시 체계가 일괄화 되어 있지 않아 외국어 번역본 제작에 따 른 어려움이 있을 때가 많다. 또한 해외작가 및 팀과의 공동제작 시 작업 공정 차이에 따른 문제, 해외 플랫폼 게재 시 서비스 파일의 규격 차이로 인한 문제 등이 지속되고 있어 이를 하나로 통일화하는 방향이 필요하다. 즉 국내에서 만든 콘텐츠 파일 형식 이 미국이나 일본 등 해외에서도 동일하게 활용되고 쓰일 수 있도록 국제 표준화와, 전 세계 어디에서도 구분할 수 있는 식별체계를 부여 하는 노력이 요구된다."

\section{마. 글로벌 위상에 맞는 인식과 체계 마련}

최근 들어 웹툰 업계에서는 성적 표현이나 차별에 관한 내용 담겨 언론상이나 학계에 서 논란이 있었던 시례가 자주 등장하고 있다. 이는 그러한 표현이 갑자기 많아졌다기보 다는 웹툰이 산업적으로나 문화적으로 영향력이 확대되면서 그에 맞는 공적인 관점과 사회적 책임에 대해 요구를 받고 있는 것으로 전문가들은 해석하였다. 다만 이제는 국내 의 차원을 넘어서 해외에까지 그 영향력을 넓히는 과정에서 국제차별에 대한 인식과 인 류 보편적 관념 및 윤리의식에 대한 인식 개선이 필요한 시점이 되었음도 요구되고 있다 는 것 또한 인터뷰에서 강조되었다. 지나친 제재나 표현의 자유 침해는 지양되어야하므 로 창작자 스스로 작업 이전에 자정 작용을 하고 글로벌 수준의 차별 금지 인식과 태도 를 갖는 게 중요하다는 점도 강조되었다.

“글로벌화가 본격적으로 진행되는 상황에서 전 세계적으로 공유하고 있는 보편적 인 인식에 반하는 내용은 다양한 지역에서 거부감을 형성하여 진출이 한창일 때 치 
명적인 리스크로 돌아올 수 있다. 국내에서 웹툰의 규모가 커지고 웹툰 작가의 사회 적 위치가 높아짐에 따라 성적인 표현이나 차별 이슈에 대한 논란이 나타났던 것과 같이 해외에서도 윕툰의 영향력이 높아질수록 이러한 요구와 논란 여지가 커질 수 있다. 따라서, 국제 보편 가치와 차별 금지 인식을 개선하기 위해 유네스코 등 공신 력 있는 국제기구에서 지정한 차별 방지조항 등을 참고하여 가이드나 지침을 제공 해주는 형식의 지원이 필요해 보인다."

또한 높아진 위상에 따라 공정 거래 환경이나 건전한 생태계 조성하는 등 법제도적인 체계가 구축되어야 한다는 목소리도 있었다. 2012년 2월 '만화진흥에 관한 법률'이 제 정되었지만 출판·정보통신·문화산업·문화예술·콘텐츠산업 등 선행 법률이 만화 분야를 포괄하는 형태를 띄고 있어 세밀한 적용에 있어서 한계가 있어왔다. 따라서 전문가들과 업계 관계자들은 현행 법률이 웹툰산업의 특수성을 반영하도록 개정하거나 웹툰산업을 위한 특별법이 마련되어야 한다는 점을 강조하였다.

“현 만화진흥에 관한 법률에서는 법의 적용 대상이 만화(작품), 만화가, 만화사업자 등에 대한 구체적인 대상을 제도적으로 적용되지 못하고 있다. 예를 들어 출판만화 의 경우 국립중앙도서관이 국제표준도서번호 발급과 납본 과정을 통해 도서의 생성 과 작가, 출판사 등의 권리자를 확인할 수 있고 정보도 관리하는 역할을 하고 있다. 하지만 웹툰의 경우에는 이 같은 정보를 관리하는 주체가 없어 유통 질서 확립과 활성화, 불법 유통에 대한 지적재산권 보호, 해외 진출에 대한 지원 등이 체계성을 지니고 발전하기 어려운 상황이다. 또한, 웹툰에 대한 기본통계와 공식적 자료의 생산이 추정치에 불과해서 기초통계 정보를 취득하기 위한 법적 책임 부여도 필요 해 보인다.” 


\section{제3절 소결}

웹툰 해외진출 관련 정책분석과 전문가 및 업계 의견조사를 통해서 다음과 같은 정책 적 시사점을 도출할 수 있었다. 먼저 해외진출 정책분석에서는 필요한 지원이지만 비어 있는 분야와 지원은 하고 있지만 부족한 지원 분야를 파악하여 현재 정책의 한계점에 대한 시사점을 제시했다. 다음으로 전문가 및 업계 의견조사에서 나타난 다양한 의견들 을 수렴하여 웹툰의 해외진출에 필요한 정책방향과 세부지원 분야를 파악하였다. 그 시 사점들을 정리하면 다음과 같다.

\section{1. 웹툰산업 해외진출 지원 정책의 한계점}

\section{가. 규모의 확대 필요}

한국콘텐츠진흥원, 한국만화영상진흥원 등 만화 및 웹툰 관련 산업을 지원하고 있는 기관에서는 2019년 발표한 만화산업발전 계획을 골자로 다양한 지원 사업이 이루어지 고 있었다. 다만 해외진출이 본격화 되면서 해외진출 지원의 수요가 증대됨에 따라 번역, 프로모션 등 기존사업의 규모를 확대의 요구가 높아질 것이 예상된다. 특히 번역의 경우 에는 웹툰 콘텐츠가 해외진출하기 위한 필수적인 요인이며 콘텐츠의 질이 좌우 될 수 있을 정도로 큰 영향력을 가진 영역이므로 더 고도화할 필요가 있다. 예를 들어 번역비 를 지원하는 것 뿐 아니라 웹툰 전문 번역인력을 발굴하고 양성하는 부분까지로 지원 영역을 확장할 여지가 있다. 또한 프로모션 지원 역시도 해외진출을 시도하는 거의 모든 웹툰 관련 업체에서 수요를 지니는 지원형태이지만 현재 소수 업체만 연속성 없이 수혜 를 보고 있는 것이 어쩔 수 없는 현실이다. 따라서 지원 규모와 대상을 확대하여 높아진 해외진출 관련 정책지원 수요를 충당할 필요가 있다. 


\section{나. 장기적인 관점에서 지원 필요}

웹툰의 해외진출은 지금까지 초기단계였기 때문에 해외진출 관련 지원 사업들은 대부 분 단기 지원이 주를 이룰 수밖에 없었다. 해외진출이 본격화되기 시작하면서 연속성을 지닌 지원사업의 개발도 요구되고 있다. 또, 해외진출 지원사업의 형태는 해외진출 직접 지원의 형태가 있지만 그 외에도 근본적으로 해외경쟁력을 강화하기 위한 기반적 차원에 서의 지원도 병행되어야 한다. 예를 들어 현재의 윕툰 산업구조가 수요가 집중되는 장르 에 편중되어 제작된다거나 웹툰 장르 자체의 인지도가 낮다거나 하는 문제점을 극복할 수 있는 근본적인 차원의 지원이 필요하다는 것이다. 결국 시장에서 자체적으로 해결해주 지 못하는 문제에 대해 보완할 수 있는 방안을 찾아 이를 극복하도록 지원하여 웹툰 산업 이 글로벌 경쟁력을 지닐 수 있도록 만드는 것이 정부의 주된 역할이 될 수 있다.

\section{2. 업계 및 전문가 인터뷰 시사점}

\section{가. 기반 구축 필요}

웹툰 산업의 특수성을 반영한 법제도 개선이 필요하다는 것이었다. 현재의 만화법 체 계상으로는 웹툰의 정보를 관리하는 주체가 없을 뿐만 아니라 유통 질서 확립과 활성화, 불법 유통에 대한 지적재산권 보호, 해외 진출에 대한 지원 등이 체계성을 지니고 발전 하기 어려운 상황이다. 이해관계자 간의 협의를 통해 점진적으로 접근해야 하지만 체계 를 정밀하게 구성하여 웹툰산업의 체계적 지원과 증진, 웹툰의 유통 현대화와 소비 활성 화 등 장기적인 관점에서 법제도 개선이 필요하다.

\section{나. 글로벌 수준의 인식 및 체계구축 필요}

전 세계에서 보편적으로 공유하고 있는 가치들이나 차별 금지 인식 등을 알고 소지하 여 지나친 거부감을 형성하는 내용이나 리스크를 줄일 수 있도록 인식을 개선해야 한다 는 부분이다. 또한 인식뿐 아니라 웹툰 isbn 개발 등을 통해 식별번호를 발급 받고 이를 통해 관리하여 통계를 파악하는 등 기록물 관리는 물론 생산과 유통 관리가 이루어질 수 있는 체계를 갖추는 것도 기초적으로 갖춰야 할 요소로 파악되었다. 

웹툰산업 해외진출 진흥 방안 연구

제6장

웹툰산업 해외진출 진흥 방안 



\section{제1절 정책 기본 방향}

\section{1. 기본 방향 설정 과정}

\section{가. 웹툰산업 해외진출 정책의 기본 틀}

Warwick(2013)에 따르면, 산업정책의 형태를 둘로 나누면 수평적(기능적) 정책과 수 직적(선별적) 정책으로 구분할 수 있다. 기능적 방식이라고도 불리는 수평적 정책방식은 시장 규제 조정이나 지식 재산권 보호 등 산업 전반에 영향을 미치는 일반적 정책들이다. 선별적 방식이라고도 불리는 수직적 정책방식은 특정산업이나 부문을 선정하여 집중적 으로 지원하거나 육성하는 방식이다. 이를 적용하고 핵심 고려사항들을 토대로 웹툰산업 의 해외진출 진흥 정책방향을 구상해보면 수평적 정책과 수직적 정책으로, 역시 크게 두 가지로 나눌 수 있다. 두 축을 그림으로 표현한 것이 [그림 6-1]이다.

수평적 정책은 웹툰산업의 저변의 확장하고 기반을 마련하는 차원의 정책방향이다. 현재의 웹툰산업은 일정 분야에 집중되어 그 저변이나 기반이 취약한 상황이다. 로맨틱 판타지 장르나 웹소설 기반의 스튜디오 제작 등 획일적인 작품들이 대량으로 양산되는 형태가 나타나고 있으며 글로벌적 문화코드와 정서의 이해도 부족한 상태이다. 따라서 폭이 좁은 상태인 현재(A)에서 목표지점(B: 글로벌 만화산업 선도)까지 도달하기 위해서 는 다양하고 질 높은 콘텐츠들이 다양하게 발생되고 산업의 면모를 갖출 수 있는 기반들 이 뒷받침되어야 한다. 그림의 표현과 같이 가로의 폭이 좁은 선형 화살표의 경우에는 해외진출 시 여러 변수로 인해 현지 수용과정에서 쉽게 꺾일 수 있으며 충성 독자로까지 자리 잡히기 어려울 수 있다. 하지만 기반이 확충되고 저변이 확대되어 웹툰의 콘텐츠가 다양해지고 스펙트럼이 두터워질 경우 목표지점까지 성장하기에 더 적합한 환경을 지닐 수 있다. 즉 기반과 저변을 두텁게 하여 면형 화살표의 형태로 목표지점으로 나아갈 때 해외진출에서의 다양한 변수와 수용과정에서의 다양성을 확보할 수 있다. 
반면 수직적 정책은 해외진출 관점에서 홍보, 프로모션, 네트워킹 지원, 현지화 지원 과 같이 직접적으로 해외진출을 지원하는 정책이다.

[그림 6-1] 윕툰산업 정책의 두 축

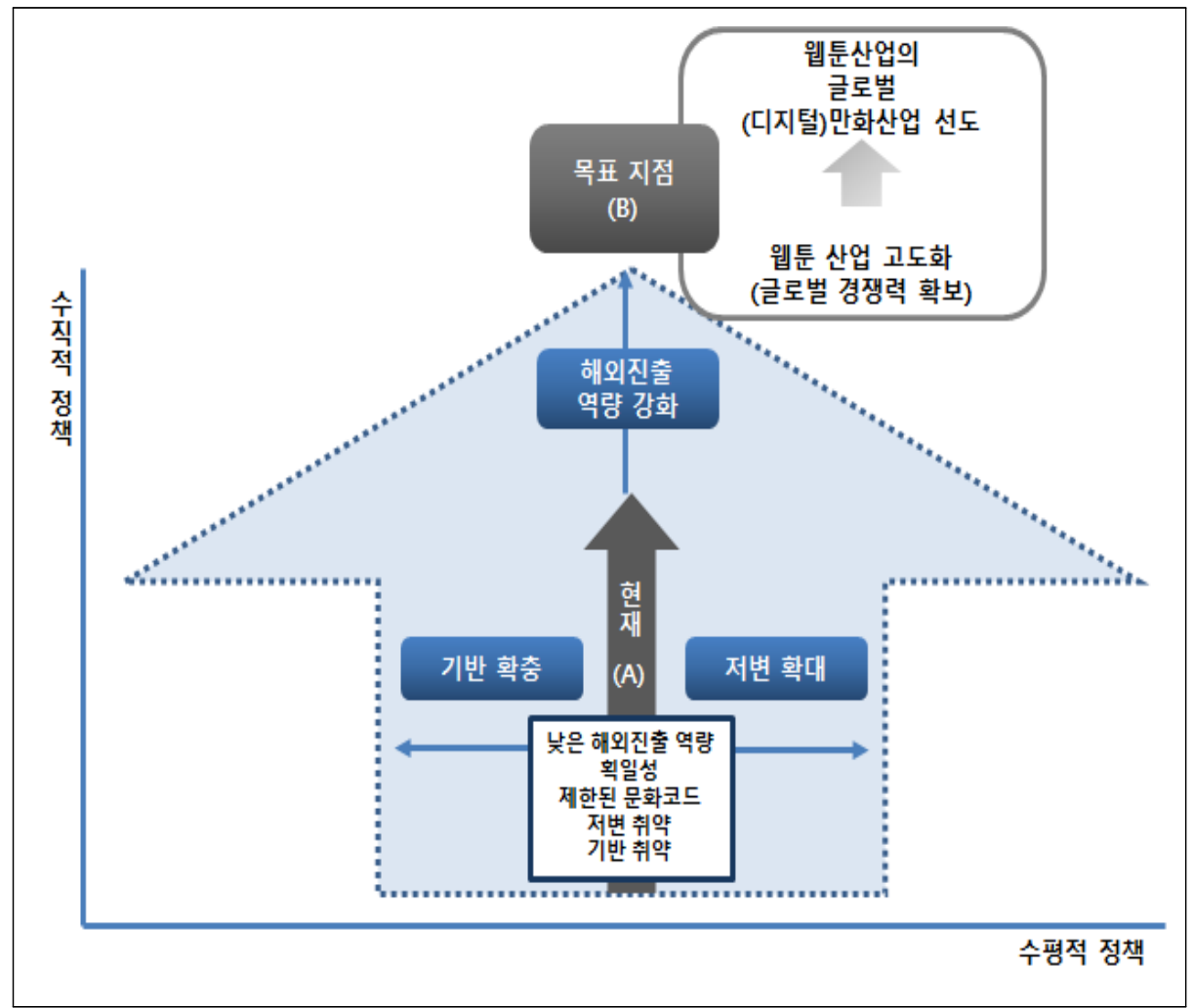




\section{나. 종합 정리 및 개선점 도출}

앞서 정리한 웹툰 현황 및 주요이슈 분석(2장), 비즈니스 모델 분석(2장), 해외진출 현황 분석(3장), 주요국 고도화과정 분석(4장), 웹툰 해외진출 정책 분석(5장), 업계 및 전문가 인터뷰(5장)의 시사점들을 종합하고 정리하여 문제점 및 개선점을 도출하였다.

\section{[그림 6-2] 종합 정리}

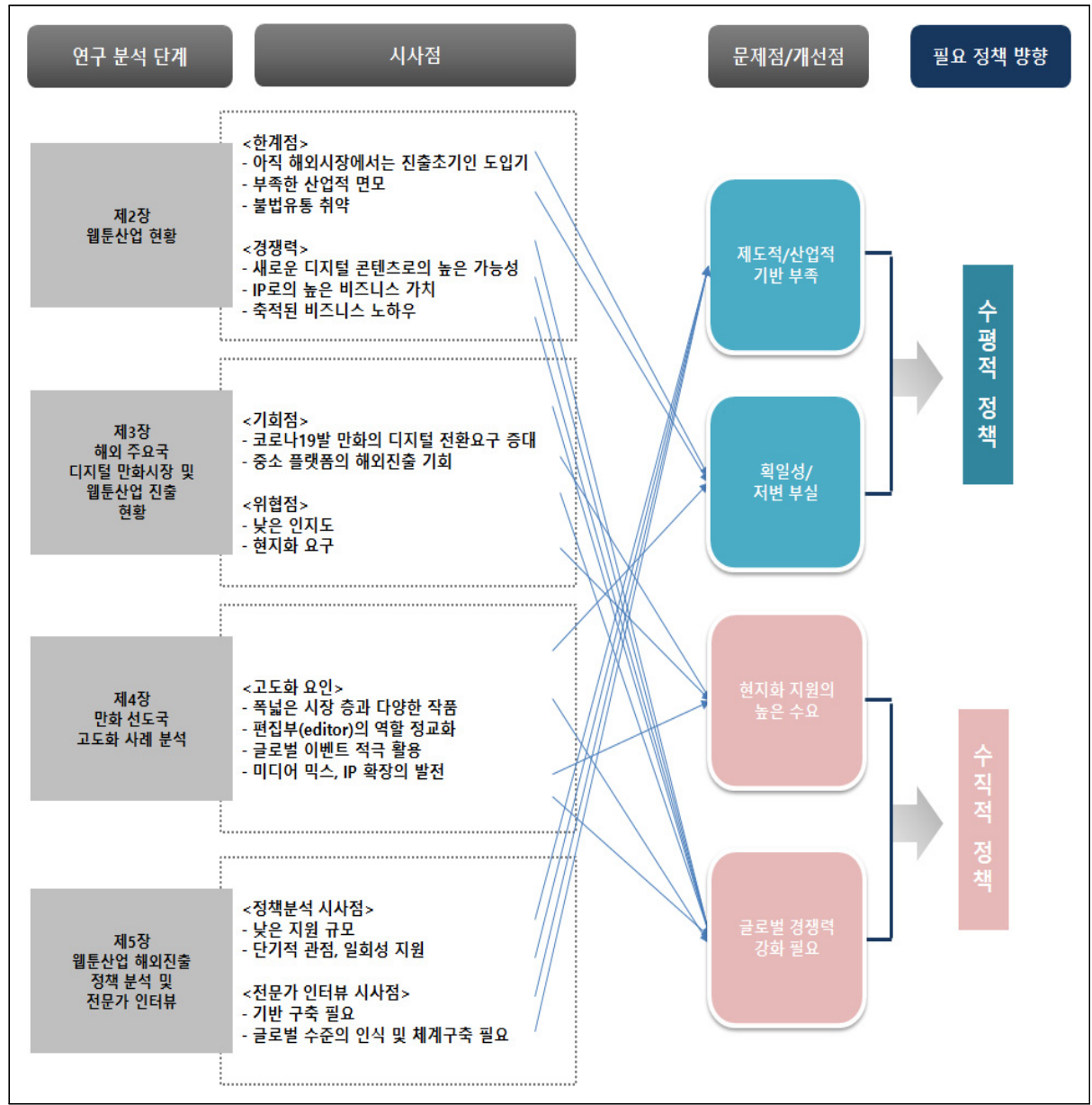

그 결과, 시사점들은 다음의 네 가지로 정리할 수 있었다. 첫째, 아직 제도적산업적 기반이 갖추어지지 못했다는 것이다. 이는 웹툰산업이 글로벌 관점에서 도입기에 불과하 다는 점과 맥락을 같이 하는 지점이며, 플랫폼 사업자들이 주도적으로 산업을 형성하는 과정에서 발생한 문제점이다. 특히, 기업 정보 없이 기본적 통계를 갖추기 어렵게 되는 
등 시장에서 해결해주지 못하는 부분에서 산업 크기에 비해 제도 기반이 열악하다.

둘째, 장르나 소재 등이 상대적으로 획일적이고 저변이 부실하다는 것이다. 최근 들어 웹툰 제작에서 가장 눈에 띄는 점은 웹툰 제작에 있어서 대형 스튜디오들이 등장하여 분업을 통한 대량생산 체제로 변하고 있다는 것이며 웹소설을 웹툰화하는 노블 코믹스 의 형태가 일반화되고 있다는 것이다. 그리고 이는 다수의 인기작들이 일부 장르에 편중 되고 소재도 비슷한 획일화를 만들고 있기도 하다. 또한 전문 편집자와 취재 및 기획 시스템의 부족 등 부실한 저변도 개선이 필요한 지점으로 지적되었다. 셋째, 글로벌 경 쟁력의 강화가 필요하다는 점이다. 이는 콘텐츠 자체의 경쟁력뿐 아니라 플랫폼 경쟁력 까지 포함한다. 아직 해외에서 웹툰은 인지도가 낮으며 모바일 기기로 세로스크롤 방식 으로 만화를 소비한다는 문법자체가 익숙하지 않다. 따라서 이를 어떻게 새로운 독자들 에게 알리고 전달하지는 지는 아직까지 선도적인 디지털 만화 플랫폼이 없는 상황에서 매우 중요한 요소가 될 수 있다. 또한 웹툰만이 지니는 원천 IP로의 가치 등 스스로 가치 를 높일 수 있는 경쟁력을 강화해야 한다. 마지막 문제점 및 개선점으로는 적극적인 현 지화에서의 어려움이다. 만화는 캐릭터에서 인종이 나타나지 않기 때문에 일반적으로 문 화적 할인율이 낮다고 생각하는 경우가 많다. 하지만, 소재와 기본적인 정서, 문화적 코 드 등 현지에서 선호할 만한 요소가 있어야 유입이 가능하다. 특히 현지의 창작인력을 발굴하거나 현지의 문화코드와 만화적 요소를 동시에 이해하는 고급 번역이 현지시장에 서 성공할 수 있는 필수적인 요소이다.

이들을 정책기본 틀로 제시한 수직적/수평적 정책에 대입해보면, 제도적·산업적 기반 부족과 획일성 및 저변 부실은 수평적 정책을 통해 해결해야 할 웹툰산업의 개선점이다. 반면 글로벌 경쟁력 강화나 현지화에 대한 노력 등은 수직적 정책으로 극복해야할 요소 들이다. 


\section{2. 정책 방향 및 방안 도출}

종합 정리에서 분류한 결과를 토대로, 단계별 정책방향을 수립하였다. 특히, 해외진출 본격화와 이를 위한 정책방안을 통해 웹툰 산업의 다음 페이지를 넘어간다는 의미로, 웹툰 용어인 SCROLL-UP을 핵심 단어로 설정하고 각 단계별로 이니셜에 따라 정책방 향을 구성하였다.

[그림 6-3] 정책 방향

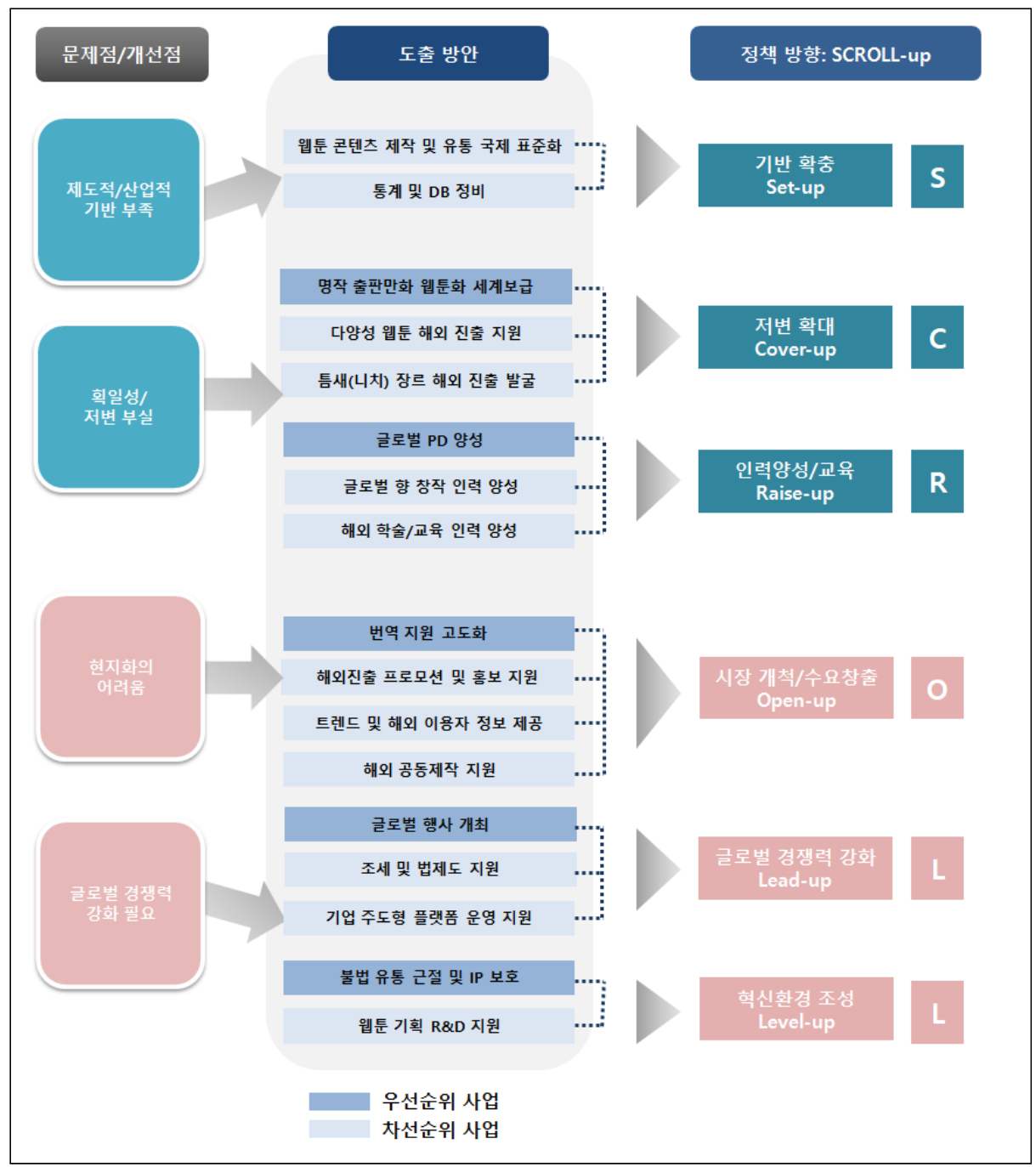


먼저 기반 확충(Set-up)은 통계 및 DB 정비, 국제 표준화 시도 등 해외진출을 위해 근간을 이루는 기반을 갖추기 위한 방안들로 구성하였다. 다음으로 저변 확대 (Cover-up)에 대한 방안들로 취약 장르 및 예술 장르 지원, 니치 분야 지원 등과 같이 국내 웹툰 산업이 폭넓고 다양한 작품들이 발생할 수 있도록 추진방안들로 이루어졌다. 인력양성과 교육(Raise-up)은 산업, 창작, 학술 차원으로 나눠서 각 부문별 인력양성 방안들을 제안하였다. 여기까지는 기반을 다지고, 저변을 확대하며 인력을 양성하는 것 과 같이 주로 웹툰 기반을 형성하는 간접적인 지원이 주를 이루는 수평적 정책 방안들이 라면, 이후부터는 해외진출을 직접적으로 지원하는 수평적 정책 방안들이 주를 이루는 것들로 구성하였다. 시장 개척 및 수요발굴(Open-up)은 새로운 시장을 발굴하는 것과 관련한 추진방안들로 번역지원, 웹툰 해외진출 프로모션 지원 등 직접적인 해외진출을 위한 사업들이 주를 이룬다. 또 글로벌 경쟁력 강화(Lead-up)는 기업 주도형 플랫폼 운 영지원, 글로벌 웹툰 행사 개최, 조세/법제도 지원 등의 방안으로 구성하였다. 마지막으 로 혁신 환경조성(Level-up)은 궁극적인 웹툰 산업의 고도화와 수출 본격화를 위해 웹 툰 기술 및 R\&D 지원, 불법 유통 근절 등의 방안들을 구축하였다. 


\section{제2절 세부 정책 방안}

\section{1. 기반 확충(Set-up)}

\section{가. 웹툰 콘텐츠 제작 및 유통 국제 표준화}

1) 배경 및 필요성

최근 전 세계 만화시장은 빠른 속도로 디지털화 되고 있다. 만화산업 선도국이라고 할 수 있는 일본과 미국은 기존 출판만화(망가, 코믹북)의 디지털화를 추진하면서 책을 읽는 방식과 환경을 뉴미디어에서 재현하는 것에 집중했다.

반면, 한국 만화산업의 디지털화는 PC와 스마트폰 같은 뉴미디어 사용자 환경에 최적 화 된 형식으로 발전했다. $\mathrm{PC}$ 의 스크롤마우스와 스마트폰의 터치 제스처 기능을 고려한 창작 형식과 구독 방식을 제시했고 일종의 온라인 오디션 방식을 통한 작가 발굴, 주1회 요일제 연재 시스템, 미리보기와 다시보기 유료 정책 등을 도입했다. 이는 기존 만화산 업의 경쟁 방식을 뒤바꿔 논 것이었고 해외 만화계는 한국의 웹툰 콘텐츠와 함께 웹툰 플랫폼의 운영 정책 전체를 학습하고 자국 시장에 반영하고 있다.

그러나, 웹툰산업의 빠른 확산만큼 다양한 문제들이 발생하고 있다. 특히, 국내 웹툰 의 해외 유통 시 외국어 번역본 제작에 따른 어려움이 있고 해외작가 및 팀과의 공동 제작 시 작업 공정 차이에 따른 문제, 해외 플랫폼 게재 시 서비스 파일의 규격 차이로 인한 문제 등이 지속되고 있다.

\section{2) 정책방안 개요}

대표적인 웹툰 플랫폼 운영 기업의 관계사 또는 제공사들은 플랫폼사가 마련한 자체 웹툰 콘텐츠 제작/유통 가이드를 통해 웹툰원본파일, 웹툰서비스파일, 웹툰메타데이터 등의 작성 원칙과 제출 기준을 준수하고 있지만 경쟁사 간 차이가 있고 해외 플랫폼 간 
에도 차이가 존재한다. 특히, 신생 기업의 경우는 이 같은 가이드 정보에 접근할 수 없어 서 다양한 시행착오를 겪게 된다.

이에 웹툰의 제작과 유통을 위한 보편적 규칙을 마련하고 이를 국제표준으로 등록하 여 전 세계 웹툰산업계가 준수하도록 해 산업의 효율성과 경제성을 강화할 필요가 있다. 이를 위해 첫째, 국내 유력 웹툰기업과 협.단체를 중심으로 웹툰창작과 유통 표준화 포 럼을 구축하고 회원사와 관계를 맺고 있는 해외기업들의 참여를 촉진해 국제적 위상의 표준화 기구를 구성할 필요가 있다. 둘째, 이 기구를 중심으로 웹툰 국제 표준 제작 공정 과 유통 형식 표준화를 추진한다. 셋째, 이와 함께 웹툰 콘텐츠만의 교유한 식별체계를 마련한다. 넷째, 표준화 기구 내에 독립적인 위원회를 구성해 표준 채택 여부에 대한 모 니터링을 실시하고 새로운 웹툰형식에 대한 수집 관리 기능을 부여한다.

3) 기대효과

웹툰 콘텐츠 제작 공정과 유통 과정에서 생산되는 데이터에 대한 국제 표준화는 웹툰 의 제작 과정과 보존 및 유통 과정의 체계성과 효율성을 강화할 것이고 기업의 웹툰 콘 텐츠 유통 시, 기업 간 웹툰 콘텐츠 제공 시 등에 있어 일관성이 유지됨으로 인해 경제성 이 강조될 것이다. 특히, 한국이 웹툰의 종주국이자 최대 생산국으로서 국제 표준화 기 구의 결성과 운영을 통해 전 세계 웹툰산업을 선도하는 국가로서의 위상과 책임성을 확 보하게 될 것이다.

\section{나. 웹툰산업 통계 및 $\mathrm{DB}$ 정비}

1) 배경 및 필요성

만화관련 정부 통계는 2006년 문화산업진흥기본법(1997년 제정)에 만화가 포함되면 서 수집·관리 되기 시작했다. 이에 따라 「만화산업백서2006」이 첫 발행된 후 정부는 조 사 해 기준 전년도의 기업 매출을 수집해 통계 자료를 작성하고 각종 연구 자료 등을 추가해 매년 백서를 발행하고 있다. 그러나 발행 시점을 기준으로 보면 통계 데이터는 2년 전 결과로 급변하는 산업환경에 대응하지 못한다는 지적이 있다.

또한, 현행 통계 자료의 만화 산업분류 항목(만화출판업/만화책임대업/만화도소매업/ 
온라인만화제작유통업)은 만화산업 중 출판분야에 집중되어 있어서 스마트미디어시대의 환경 변화를 반영하지 못하고 있다.

이와 함께 만화산업의 가장 중요한 지표가 될 수 있는 만화작품 생산량에 대한 정보 역시 수집·관리 되지 못하고 있다. 국립중앙도서관이 ISBN발급과 납본 업무를 중심으로 발간물 정보를 관리하고 있으나 도서류에 국한 된 측면이 있고 한국만화영상진흥원(한국 만화박물관, 디지털만화규장각)이 만화도서와 웹툰의 발행 정보를 자체 수집해 관리하고 있으나 전수 등록 여부를 판단할 수 없는 실정이다.

\section{2) 정책방안 개요}

전통적인 만화산업이 만화도서라는 물적 대상에 기반 했다면 최근 만화산업은 디지털 파일형식인 웹툰을 중심으로 발전하고 있다. 웹툰은 정기간행물의 속성을 지니고 있고 간 행물에 게재된 연재물의 형태를 지닌다. 내용과 형식에 따라 세부 장르가 구분되고 이용하 는 매체에 따라서도 새로운 분류 기준이 마련될 수 있다. 민간주도 하에 연재 회차별로 이용등급을 표기하고 있고 사후 심의를 진행하고 있다. 국내뿐만 아니라 다양한 언어권에 서 다양한 유형의 서비스 플랫폼을 통해 국내에서 생산된 웹툰을 유통하고 있다.

이에 웹툰만을 독자적으로 등록 관리하는 시스템과 이를 기존 만화산업(만화도서류 포함) 범주에서 통합 관리할 수 있는 방안이 필요하다. 즉, 만화산업의 생산물을 도서류 라는 물적 대상 기준에서 '권리’ 기준으로 전환해야 한다. 콘텐츠 생산자(작가, 출판사, 제작사 등)가 콘텐츠를 창작하거나 제작해 공표하는 시점부터 '권리' 가 발생되고 권리에 기여한 자와 권한을 지닌 자의 계약에 의해 콘텐츠의 생산 유형과 유통 범위가 결정된다. 이를 체계적으로 관리하고 통제할 수 있는 방안을 마련하고 산업계 내외부에서 이 정보 에 접근할 수 있도록 해야 한다.

이를 위해 첫쩨, 웹툰산업을 포괄하는 만화산업 분류 기준을 재정립하고 국가 통계 항목을 정비해야 한다. 둘째, 만화산업의 생산물 관리를 위한 메타데이터 수집 체계와 식별자 발급체계를 마련하고 전담기구를 지정해야 한다. 이에 대한 혜택을 부여할 수 있는 법·제도의 정비도 필요하다. 셋째, 생산정보를 기반으로 해당 생산물의 유통정보가 추가 관리 될 수 있도록 하고 동일 생산물과 유사 생산물의 유통정보를 추적 관리 할 수 있는 체제도 마련되어야 한다. 넷째, 근본적으로 만화산업 내 생산물의 판매와 소비 
현황 정보가 공개될 필요가 있으나 데이터 수집의 복잡성, 민간사업 영역의 민감 정보 침해 문제 등이 있을 수 있다. 다만, 선행 정보의 관리 체계가 마련되면 판매시점 이전의 발간 정보를 집계할 수 있고 이를 근거로 생산물의 소비 추세를 파악할 수 있을 것으로 보인다.

\section{3) 기대효과}

최근 한국의 만화산업은 웹툰을 중심으로 전 세계 시장에 유통되고 있다. 반면, 국가 의 관리 시스템은 산업의 변화와 발전을 따르지 못하고 있는 형국이다. 특히, 만화산업 은 전통적으로 정보의 비대칭성이 강한 문화산업 분야로 알려져 있다. 생산의 주체인 창작자와 제작자, 소비와 재생산의 주체인 유통사, 일반소비자와 기업소비자 간에 정보 의 격차가 심하다. 이에 따라 산업 내 불신이 팽배하고 신규 사업자의 시장 참여가 제한 됐다. 만화산업에 대한 분류와 통계기준 정비, 생산과 유통 정비의 체계화와 정보 접근 성 강화는 만화산업 내 정보의 비대칭성을 해소하는 한편, 국가 산업 발전과 만화산업 경쟁력 제고에 기여할 것이다.

\section{2. 저변 확대(Cover-up)}

\section{가. 명작 출판만화 웹툰화 세계보급}

\section{1) 배경 및 필요성}

2000년대 이후 웹툰이 출판만화 시장을 대체하고 해외 진출이 본격화하면서 명작으 로 인정받는 출판만화를 전 세계에 소개할 기회는 상대적으로 부족했다. 자국 만화시장 으로도 충분했던 일본이 '망가'라는 브랜드로 세계시장에 적극적으로 진출하기 시작한 것은 2000 년대 이후다. 드래곤볼, 슬램덩크, 원피스, 나의 히어로 아카데미아, 귀멸의 칼날 등 메가 히트 작품뿐만 아니라 다니구치 지로 같은 작가의 작품들이 잇달아 국제 만화상을 수상하면서 흥행과 작품성 양쪽에서 세계 최고의 만화 강국으로 인정받았다.

국내의 우수한 명작, 걸작 만화들을 웹툰화하여 해외에 보급하는 전략은 한국만화산 업의 사기를 진작시키고, 한국 웹툰 산업이 해외 시장에 굳건히 뿌리내리는데 기여할 
것으로 기대된다. 또한 상대적으로 위축된 출판만화 분야에 대한 해외진출도 모색할 수 있어 장기적으로 한국만화·웹툰산업의 확장에 기여할 수 있다.

\section{2) 정책방안 개요}

해외 독자들에게 반향을 일으킬 수 있는 한국의 걸작 출판만화들을 발굴하고 이를 웹 툰화하는 사업을 할 필요가 있다. 일본은 세로쓰기 말풍선에 페이지를 오른쪽에서 왼쪽 으로 넘겨가는 독서법으로 인해 자국 만화의 해외 진출에 상당한 애로를 겪었다고 한다. 해외 진출시 해외 독자들의 취향에 부합하는 현지화에 공을 들여야 한다.

현재 흥행에 성공했던 기존의 출판만화를 웹툰화하여 서비스하는 사업이 일부 전개되 고 있다. 명작 출판만화를 웹툰화하는 것은 온라인, 모바일 앱을 통해 '만화'를 보급하는 경로를 확보한다는 점과 세계 시장에 주도적 위치를 차지하고 있는 한국 디지털 만화의 위상을 공고히 한다는 면에서 유리하다.

세부적인 사업 과정은 다음과 같다. 먼저, 국내 기출간 된 우수 (명작)출판만화의 발굴 하고 사업자를 선정한다. 그리고 선정한 사업자를 통해 웹툰화 작업(편집, 채색)이 이뤄 지고 해외 웹툰 플랫폼에 실어 서비스가 되도록 한다. 또한 작품 홍보, 인덱스 제공 후속 조치까지 시행하는 것을 포함한다.

\section{3) 기대효과}

본 사업을 통해 국내 출판만화의 디지털 만화(웹툰)화를 통한 해외 확산에 직접적인 지 원으로 시장 개척에 도움이 될 것으로 기대가 된다. 또한 한국 걸작, 명작, 우수 만화의 전통을 유지, 보존하면서 해외 진출뿐만 아니라 국내 독자에게도 소개할 기회를 아울러 가질 수 있다. 이는 한국만화의 문화예술적 우수성을 해외에 알리는데도 기여할 수 있다.

\section{나. 다양성 웹툰 해외 진출 지원}

1) 배경 및 필요성

해외에서 크게 인기를 끌고 있는 한국의 윕툰은 대체로 상업적 성과가 높은 특정 장르 에 편중 된 경향이 있다. 
아이디어와 참신한 소재로 무장한 웹툰과 만화가 너무 한 쪽 방향과 비슷한 흐름으로 만 흘러간다는 불만이 적지 않다. 우리 웹툰과 만화가 국제적으로 인정받고 있고, 경제 적 산업적으로 성공을 하고 있다면 유럽 초기 만화시장의 형성처럼 당연히 작가에게 더 많은 기회가 보장되는 시스템으로 이어져야 할 것이다. 안정된 환경과 가치의 인정은 좀 더 다양하고, 완성도 높은 작품으로 돌아올 것이기 때문이다. 너무 대중적인 기호에 만, 상업적인 성공에만 편승하게 된다면 그 문화의 저변은 얕아질 수밖에 없다. 그 장르 를 풍성하게 하는 것은 다양하고 풍부한 시도에 비롯되는 게 일반적이다.72)

우리나라에서 제작 연재되는 작품의 수는 연간 1 만종 이상에 달하고 신작만 2,000 3,000 종에 이르고 있을 정도로 다양하나 해외 시장에 선보이는 작품은 수백 종에 불과 할 정도로 한정적이다. 장르 편중 현상을 타파하고 국내 웹툰 해외 진출 종다양성 활성 화 측면에서 취약 분야의 우수한 작품을 발굴하여 해외 시장에 소개하는 것은 필요한 정책이다.

아소다로 일본총리가 주도하여 제정한 국제만화상은 '문화 외교의 일환으로 해외에서 만화문화를 보급하는데 공헌한 만화가를 표창'하는 상으로 그동안 대부분 수상작은 중 국, 동남아와 유럽에 치우쳐 있다. 한국은 응모편수도 적었지만 상업적인 웹툰의 해외 진출에 주로 관심을 두고 있기 때문에 작품성 있는 만화의 해외 소개에는 소극적이었다.

2020년 만화계의 오스카로 불리우는 하비상을 수상한 김금숙작가의 ‘풀', 같은 해 프 랑스 아시아만화상 최종후보에 오른 김홍모의 '좁은방', 오영진 작가는 2008년 '남쪽 손 님'으로 수상의 시례에서 보듯 작품성 있는 한국의 다양성 만화는 해외 시장에서 충분히 가치를 인정받을 수 있을 것으로 예측된다.

\section{2) 정책방안 개요}

국내 대표적인 만화 시상 제도인 부천만화대상, 오늘의 우리만화, 대한민국만화어워 드 등에서 수상한 작품들과 인스타그램, 오픈 마켓 등 독립 웹툰 플랫폼 등에서 높은 평가를 받은 작품들을 발굴하여 플랫폼 등을 통해 해외에 소개한다. 그리고, 웹툰 플랫 폼뿐만 아니라 해외전시, 강연 등 문화교류 행사 등과 연계하여 다양한 작가와 작품이 소개 될 수 있도록 주선하고, 해외 유명 만화페스티벌, 시상, 행사 등에서 조명될 수 있

72) 뉴스피크(http://www.newspeak.kr) 
도록 정책적으로 지원한다.

이를 구체화하기 위한 과정은 다음과 같다. 먼저 국내 주요 만화시상식 전수 조사하고 선정위원회를 통해 대상 작품 선정한다. 선정한 작품을 대상으로 웹툰 플랫폼 사업자와 의 계약을 지원하고 이 플랫폼을 통해 해외로 진출을 도모한다. 그리고 작품 홍보, 인덱 스 제공 후속 조치까지 제공한다.

\section{3) 기대효과}

본 사업을 통해 웹툰의 해외 진출에 따른 종다양성을 확장하고, 비활성화 장르 웹툰작 가들의 창작 동기 부여와 의식을 고취할 수 있다. 나아가 한국 웹툰이 플랫폼을 통한 단순한 작품서비스에만 머물지 않고 행사, 전시, 시상 등 문화교류 측면에서도 진출을 병행한 바는 보완적 측면도 부각시킬 수 있다.

\section{다. 틈새(니치) 장르 해외 진출 발굴}

\section{1) 배경 및 필요성}

틈새 전략은 고객 구매 패턴, 기호, 선호도 등을 분석하여 특정 시장을 집중적으로 공략한 것을 의미한다. 제한된 자원에 집중하여 비교우위를 확보 할 수 있는 기회를 제 공한다는 점에서 시장을 형성하고 지속시키기 유리하다. 특정 소비자 집단, 일부 품목, 특정 지역을 집중적으로 공략하는 것이다. 웹툰의 해외 진출에도 틈새 시장 공략을 위한 정책이 필요하다.

해외 디지털만화 시장의 동향을 주기적으로 분석하여 해당 국가별 선호하는 작품 등 을 인덱스하여 업계에 자료를 제공할 필요가 있다. 또한 기관, 기업 간의 상설적인 네트 워크 형성과 전략 마련으로 적극적인 대응책을 수립할 필요가 있다.

슈퍼히어로 그래픽 노블 중심의 미국, 예술성 짙은 회화적 감수성이 중요한 유럽, 대 중적인 오락물이 한국과 유사한 형태를 보여주는 일본 등 각 지역별, 국가별 특성 분석 을 통해 해당 지역의 틈새시장을 노리는 작품을 제작, 유통하는 것이 필요하다. 


\section{2) 정책방안 개요}

현재 우리나라 웹툰 산업계에서는 소외되어 있는 분야를 점검하고 해외 진출을 바라 고 있으나 여의치 않는 중소 플랫폼 중심의 수요를 파악하여 반영할 필요가 있다. 기업, 기관 간의 네트워크 구축과 상설적인 포럼 등의 개최가 병행되어야 할 것으로 여겨진다. 이를 위해서 해외 주요 권역별, 국가별 디지털 만화 시장 조사를 진행하고 관련 웹툰플 랫폼, 에이전시 등에 자료 제공한다. 그리고, 해외 틈새 웹툰 시장 공략 세미나 등을 개 최하여 다양한 정보와 의견이 교류가 이루어지도록 한다. 또 기관, 기업 간 네트워크 형 성하고 실질적으로 틈새 웹툰이 해외에 진출할 수 있도록 연계하여 지원을 실시한다.

\section{3) 기대효과}

웹툰 해외진출의 다각화와 다변화를 위한 전략적 정책 지원의 결실이 맺어질 수 있다. 해외 진출 관련 기업과 작가들의 네트워크를 구축하여 중장기적인 해외 진출 정책 수립 에 기여할 수 있다.

\section{3. 인력 양성/교육(Raise-up)}

\section{가. 글로벌 PD 양성}

1) 배경 및 필요성

앞서 살펴본 바와 같이 한국 웹툰 산업은 성장기를 지나면서 고도화가 필요한 시점에 이르렀다. 특히 해외진출이 본격화되는 시점과 맞물려 더 깊이 있는 고품질의 작품과 현지시장의 수요를 반영해야하는 과제를 요구받고 있다.

세계적 수준으로 웹툰이 고품질화 및 글로벌화 되기 위해서는 제작과정의 구조적인 개선이 필연적으로 따라야할 것으로 전문가들은 지적하고 있다. 전문가 인터뷰 결과와 선도국들의 고도화 과정에서 살펴봤듯이 대다수의 만화 출판사들은 전문 $\mathrm{PD}$ 들을 작가 에게 지원하여 작품의 질을 높이고 있다. 작가 혼자서 기획하고 취재, 편집까지 하기는 물리적인 한계가 존재할 뿐 아니라 전문성도 떨어질 수 있기 때문에 작품마다 10명 내외 의 전문 $\mathrm{PD}$ 들이 붙어서 작품을 품질을 높이는데 기여하고 있다. 
하지만, 아직 국내에서는 이러한 전문 $\mathrm{PD}$ 인력이 부족한 상황이다. 웹툰 제작사들이 대형화되고 스튜디오화 되는 과정에서 전문 $\mathrm{PD}$ 에 대한 수요가 높아지고 있음에도 경험 과 역량을 갖춘 인력을 구하는 것은 매우 어려운 실정이다. 따라서 작품의 품질을 높이 는 기능 뿐 아니라 해외진출 과정에 있어서도 마케팅적으로 지원해 줄 수 있는 글로벌 $\mathrm{PD}$ 를 적극적으로 양성할 필요가 있다.

\section{2) 정책방안 개요}

전문적으로 글로벌 $\mathrm{PD}$ 를 양성하기 위해서는 다음의 세 부문 모두에서 글로벌 관점으 로 체계적인 교육과 실습이 필요하다. 먼저 글로벌 공동제작 파트는 해외의 인력들과의 협업을 이끌어 글로벌 제작이 이루어질 수 있도록 만드는 프로듀서이다. 이들은 해외의 제작 인력들이 협업하여 공동제작을 할 수 있도록 하거나, 각 국가의 특화된 분야에 적 합하게 역할을 부여하고 배치하여 고품질의 작품이 배출될 수 있도록 이끄는 역할을 한 다. 다음으로 글로벌 에디터는 현지의 문화를 파악하고 있는 인력으로, 언어, 종교, 관습 등 현지의 문화를 반영하여 편집을 진행해 거부감 없이 현지에 작품이 받아들여 질 수 있도록 기여하는 프로듀서이다.

마지막으로, 글로벌 매니지먼트는 원작이 영화나 드라마, 뮤지컬 등 해외에서 다른 장 르로 OSMU 되는 과정을 적극지원하고 판권관리나 법적 거래를 전문적으로 진행해주는 역할을 맡는 프로듀서이다. 또한 이들은 현지의 광고나 홍보까지 전문적으로 관리하여 글로벌 에이전시 기능과 매니지먼트 기능을 동시에 갖는다.

〈표 6-1〉 글로벌 PD 과정 필요 양성부문

\begin{tabular}{c|c|c}
\hline 부문 구분 & 역할 & 요구 역량 \\
\hline 글로벌 공동 제작 & 글로벌 기획 및 해외 제작 인력과의 협업 지원 & 글로벌 네트워크, 기획 \\
\hline 글로벌 에디터 & 현지화 등 언어별 또는 문화별 편집 지원 & 현지 문화 파악 \\
\hline 글로벌 매니지먼트 & 미디어 믹스, 판권 관리, \\
& 현지의 광고/홍보 등 마케팅 측면에서의 지원 & $\begin{array}{c}\text { 현지 법 및 계약관행 } \\
\text { 현지 광고, 홍보 }\end{array}$ \\
\hline
\end{tabular}

이렇게 세 분야로 체계적으로 구분하여 커리큘럼을 구축하고 해외진출을 직접 진행 한, 경험 있는 웹툰 플랫폼 및 에이전시 해외진출 담당자를 섭외하여 강사로 투입해야 효과적인 글로벌 PD 양성이 이루어질 수 있다. 이들은 해외진출에 있어서 가장 현장을 
잘 아는 강사 자원일 뿐 아니라 글로벌 PD 양성과정 중 우수 수료생들을 업체와 연결하 여 취업까지 유치할 수 있는 자원이기도 하다. 또 웹툰 아카데미 사업, 웹툰 PD 전문가 양성 사업 등 기존의 인력양성 사업과의 연계를 통해 시너지효과를 창출할 필요가 있다.

\section{3) 기대효과}

본 정책방안을 통해서 얻을 수 있는 가장 큰 효용은 글로벌향 웹툰 인력을 배출할 수 있다는 것이다. 글로벌 진출이 본격화되고 있지만 해외의 정보가 아직 부족하고 해외진 출 노하우가 축적되지 않은 현 상황에서 글로벌 인재는 국내의 폭발적으로 늘고 있는 국내 웹툰 공급과 해외의 웹툰 수요 간의 간극을 메워줄 수 있는 역할을 할 것으로 기대 된다. 또한 아직 스튜디오화 과정에서 본격화되지 못한 $\mathrm{PD}$ 시스템의 정착에도 기여하여 좀 더 고도화되고 전문적인 웹툰 제작 시장형성에도 도움이 될 것이다.

\section{나. 글로벌 향 창작 인력 양성}

1) 배경 및 필요성

국내 웹툰의 해외 진출은 완성된 작품을 기반으로 플랫폼, 에이전시 사업자가 중심이 되어 진행되고 있다. 해당 지역이나 국가에 최적화된 작품이라기보다 국내 시장에서 1 차 검증된 작품을 중심으로 수출이 이루어지고 있는 것이다. 〈나 혼자만 레벨업〉, 〈여신강 림〉, 〈이태원 클라쓰〉 등 국내뿐만 아니라 해외에서도 성과를 내고 있는 작품도 있으나 웹툰플랫폼 사업자의 경우 현지에서 직접 서비스를 하면서 해당 국가에서 신인을 발굴 작가로 프로모션하는 사업도 아울러 전개하고 있다.

네이버웹툰은 도전만화 모델을 본 딴 CANVAS을 통해 현지 신인을 발굴하고 있다. 네이버웹툰 북미 ORIGINAL에서 제공하는 한국웹툰과 북미웹툰의 비율은 $1 ; 1$ 이며 상 위 20 위권 웹툰의 $80 \%$ 는 북미웹툰이 차지하고 있다.

이를 미루어보아 우리나라 웹툰이 북미 시장에서 성공하기 위해서는 북미시장에서 수 요를 충족시켜줄 수 있는 글로벌 창작인력이 필요하다. 


\section{2) 정책방안 개요}

한류 콘텐츠의 해외진출 전략을 참고하여 현지화에 적합한 작가, 에이전시 등을 발굴 하고 해외 시장을 직접 겨냥한 인력을 양성할 필요가 있다. 해외 작가, 에이전시 등을 발굴 국내 작가, 에이전시와 공동제작의 형태로 진출하는 것도 고려해 볼만하다.

또, 미국, 일본, 중국시장에서 성과를 낼 수 있는 특화된 현지 적응형 작가 배출을 목 표로 장기적인 교육 투자가 필요하다. 이를 위한 글로벌 향 창작 인력 양성의 세부 사업 내용은 다음과 같다.

(1) 국내 작가 해외 다이렉트 연재 교육 시행

(2) 해외 프로모터, 에이전시 통한 공동 제작 추진(글/그림)

(3) 해외 거점 둔 웹툰 창작스튜디오 설립, 운영 지원

(4) 동남아 등 인건비 낮은 지역 후반작업 스튜디오 설립 지원

(5) 국내 작가 해외 현지 탐방 지원

\section{3) 기대효과}

국내 웹툰 시장에 머물고 있는 지망생 및 신진작가, 기성 작가의 다변화된 시장 직접 진 출 효과를 거둘 수 있다. 획일화, 편중된 웹툰 장르에서 세계 각국에서 통용될 수 있는 다양 한 작품을 제작, 유통하는 글로벌 스탠다드 웹툰 제작의 기초를 다질 수 있다. 한국웹툰의 해외 진출을 작품만이 아닌 제작시스템을 이식할 수 있을 뿐만 아니라 공동제작 등을 통해 한국 웹툰의 잠재력을 극대화하고 웹툰의 세계 표준을 모색하는데 기반이 될 수 있다.

\section{다. 해외 학술/교육 인력 양성}

\section{1) 배경 및 필요성}

웹툰의 해외 진출과 함께 학술교류와 해외에서의 웹툰 교육 인력을 양성하는 사업도 추진해 볼 필요가 있다. 현재 국내에서는 한국만화영상진흥원에서 〈세계웹툰포럼〉이라 는 행사를 통해 해외 연구자 등과 세미나를 진행하고 있다. 한국만화가협회, 우리만화연 대 등 주요 만화 단체들은 1996 년부터 한국, 중국, 일본, 대만, 홍콩 등이 참가하는 〈국 
제만화가대회>를 매년 돌아가면서 개최한다. 국제만화가대회에서는 전시회 뿐만아니라 세미나, 포럼도 곁들이고 있어서 학술적인 교류도 병행하고 있다. 〈세계웹툰포럼〉과 〈국 제만화가대회>를 제외하면 서울국제만화애니메이션페스티벌과, 부천국제만화축제 등에 서 해외 작가나 연구자를 초대하는 사례가 있으나 단발성에 그치고 있다.

현재 국내 만화웹툰계에서는 웹툰고유식별체계의 국제 표준을 만들기 위한 논의를 활 발하게 이어오고 있다. 디지털만화 고유식별체계의 국제적 표준 제정과 같은 학술, 연구 교류 등은 한국 웹툰의 세계 종주국위상 강화에 활용될 수 있다.

한국만화영상진흥원은 2015년부터 전국 각지에 〈웹툰체험관〉 40 여개소를 개설하여 운영지원하고 있으며, 해외에서는 처음으로 베트남 호치민에 개설한 바 있다. 〈해외 웹 툰 체험관>은 한국식 웹툰 창작에 필요한 교육 기회를 제공하고 있으면 양성된 작가가 한국 웹툰작품과 현지에 서비스되는 웹툰 플랫폼에 활동할 기회를 알선하고 있다. 이러 한 기존 사업을 더욱 확대하여 한국형 웹툰교육을 보급하는 것도 필요하다.

\section{2) 정책방안 개요}

현재 한국만화영상진흥원은 〈국제만화가대회〉 사무국을 운영하고 있다. 〈국제만화가 대회>는 한중일, 대만, 홍콩 등 극동지역 주요 5 개국 만화가들이 함께 참여하는 세계 유 일의 작가 네트워크다. 〈국제만화가대회〉를 단순한 친목 모임에서 학술, 연구, 사업화까 지 연계할 수 있는 규모로 성장 시킬 필요가 있다. 또한 한국만화웹툰학회 등을 통해 국 제 학술계와 네트워크를 유지하고 관리할 수 있는 학술 인력도 양성, 운영할 필요가 있다.

한국만화영상진흥원은 〈웹툰체험관〉의 해외 진출도 도모하고 있으며 2019년, 베트남 에 최초로 해외 체험관을 운영하고 있다. 기존의 사업과 교육 거점을 활용하여 사업을 전 개한다면 효율적인 운용이 가능할 것으로 예상된다. 이를 위한 세부 사업은 다음과 같다.

(1) 〈국제만화가대회〉 사무국 -> 학술행사 교류 강화

(2) 주요 지역 학회, 연구자 교류 지원 -> 국제 포럼 창설

(3)〈세계웹툰포럼〉 지원 강화

(4) 〈웹툰체험관〉 해외 거점 확대(북미, 동남아, 중국, 일본 등)

(5) 〈웹툰체험관〉 교육강사 양성 및 파견 -> 현지 작가 강사교육 병행 


\section{3) 기대효과}

한국웹툰의 세계화를 위한 국제적 네트워크 형성을 기대할 수 있다. 한국이 거점 역할 을 하고 있는 〈세계웹툰포럼〉, 〈국제만화가대회〉, 〈해외 웹툰체험관〉의 활성화를 통해 이미 만들어진 초석위에 결실을 맺는 방향으로 나아가는 효과를 거둘 수 있다.

\section{4. 시장 개척/수요 창출(Open-up)}

\section{가. 번역 지원 고도화}

1) 배경 및 필요성

번역은 웹툰의 해외진출에 있어서 기본 전제이자 작품의 품질을 높이는 핵심 요소 중 하나이다. 웹툰은 그림과 함께 텍스트를 읽음으로써 서사를 이해하고 콘텐츠를 향유할 수 있게 된다. 따라서 해외진출에서 얼마만큼 작품을 잘 이해하고 현지의 문화와 정서를 고려한 단어로 번역하는 지는 작품 본연의 이야기를 잘 전달하는 것은 물론이며 문화적 할인율을 낮추는 등 작품의 성공에 있어서 적지 않은 역할을 수행한다.

하지만 웹툰과 만화의 문법을 잘 이해하면서도 한국과 동시에 해외 현지의 언어와 문 화를 완벽히 파악한 웹툰 전문 번역인력을 발굴하는 일은 쉬운 일이 아니다. 웹툰 번역 은 일반 번역과는 결이 다른 전문성이 요구되기 때문이다. 웹툰 번역은 시각 언어에 대 한 이해, 의성어 의태어 표현, 말풍선의 활용 등 이해해야할 요소가 많다. 이러한 부분 때문에 웹툰을 즐기지 않는 일반 번역인력으로는 웹툰 번역을 하기 부족하며 AI 번역으 로도 대체하기 어려운 분야이다. 중소 플랫폼사뿐 아니라 대기업 플랫폼사에서도 고급 웹툰 전문인력의 수요가 높은 이유가 바로 이러한 특성과 희소성 때문이다.

정부정책 차원에서 전문 웹툰 인력을 발굴하고 이들 자원을 활용하여 번역을 지원하 는 일은 해외진출을 할 수 있도록 직접적으로 기여하는 방안이다. 또 동시에 한국에서 생산된 신규 콘텐츠를 빠른 속도로 정식 유통을 가능하게 하여 불법유통을 방지하는 간 접적인 역할까지 하는 중요한 해외진출 지원방식이다. 


\section{2) 정책방안 개요}

번역을 통해 해외진출을 지원하기 위한 구체적인 방안으로는 먼저, 번역비를 직접 중 소 플랫폼사나 에이전시 등에 지원하는 현재의 번역지원 사업의 규모를 키우는 것이 있 을 수 있다. 한국만화영상진흥원에서는 웹툰 사업자들을 대상으로 미리 번역자나 번역기 업이 세팅되어 있는 상황에서 번역지원사업을 신청하면 최종결과물을 검토한 이후 번역 비를 제공해주는 수출작품 번역지원 사업을 진행하고 있다. 다만 2020년 기준으로 70 개 작품, 6억 원 규모로 현재 본격화되고 있는 해외진출의 양이나 중요도에 비해서 예산 이나 대상이 매우 부족한 실정이다. 따라서 다량의 우수 웹툰작품들이 해외에 적극적으 로 진출할 수 있도록 그 규모를 확대할 필요가 있다.

다음으로 웹툰 번역 인력 풀 구축이 필요하다. 앞서 설명한 바와 같이 웹툰 번역은 한국어를 현지의 언어로 문화코드에 맞춰 번역해야하기 때문에 전문성이 필요한 난이도 가 높은 분야의 일이다. 그래서 웹툰업체들에서는 재한 외국인을 대상으로 웹툰 번역을 시도하고 번역인력 수급을 위해 다변화를 시도하고 있는 중이다. 정부에서도 문화원이나 세종학당 등의 주재원 자원을 활용하여 번역인력 풀을 확보하는 것은 효과적인 웹툰 번 역인력 발굴 방법이 될 수 있다. 특히 한국 문화에 대해 관심이 많은 현지인들이 한국어 를 배우기 위해 적극적으로 모인다는 특성을 활용하여 한국어 능력시험 등에서 검증된 인력을 풀에 등록시키고, 이를 국내에서 해외진출을 시도하고 있는 업체들과 연결하는 시스템을 갖출 필요가 있다. 또, 유튜브 등 영상콘텐츠에서 자생적으로 번역되어 생산되 는 콘텐츠들과 같이 자생적으로 웹툰 번역이 이루어지는 시스템을 구축하여 검증된 웹 툰 번역인력을 발굴하고 이들을 업체와 연결시키는 모델의 구축도 요구된다.

\section{3) 기대효과}

번역을 통해 본 콘텐츠의 품질을 높여 해외진출에 성공한 사례는 웹툰뿐 아니라 타 장르에서도 많이 나타나고 있다. 대표적으로는 영화 〈기생충>의 번역을 맡아 해외현지 문화에 맞도록 작업을 진행해 오스카 상을 수상하는 데에도 기여했다고 평가받는 번역 가 달시 파켓이 있다. 웹툰에는 아직 이러한 스타번역가가 나타나지는 않았지만, 다양한 고급 번역인력의 발굴을 통해 웹툰 작품 자체의 품질을 높여 해외진출을 활성화하는데 기여할 수 있다. 특히 다양한 웹툰 고급 번역인력들이 발굴되고 이들을 정부에서 연결시 
켜준다면 고급 번역자원을 활용하기에 자본력이 부족한 중소웹툰 업체의 입장에서는 가 장 효과적이 해외진출 전제조건을 갖출 수 있게 될 것이다.

\section{나. 해외진출 프로모션 및 홍보 확대}

1) 배경 및 필요성

해외시장에 진출하고 성공적으로 정착하기 위해서는 현지 시장의 비즈니스 당사자들 과의 접촉이 우선적으로 필요하며, 이들과 협의와 교섭을 통해 현지시장에 침투하는 것 이 가장 효과적인 방법이 될 수 있다. 실제로, 한국콘텐츠진흥원이 웹툰 IP를 보유한 플 랫폼 및 에이전시를 대상으로 설문조사한 결과에 따르면 해외 비즈니스를 위해 가장 필 요한 요소는 '해외 바이어/유통사와의 네트워크 구축'이 $59.5 \%$ 로 가장 높게 나타났다. 하지만, 중소규모의 콘텐츠 기업이나 해외진출을 처음 시도하는 콘텐츠 기업의 경우에는 접촉점 자체를 만들기 힘들며, 접촉이 되더라도 의사소통 등의 문제로 원활한 비즈니스 가 창출되기 어려운 게 사실이다. 따라서 IP 쇼케이스, 글로벌 IP 공동포럼, 현지 네트워 킹 데이와 같은 프로모션 행사를 기획하고, 또 그 가운데 거래가 잘 이루어질 수 있도록 피칭, 홍보 영상 등을 지원하는 체계적인 프로모션 및 홍보지원이 필요하다.

\section{2) 정책방안 개요}

코로나19로 전 세계가 동시에 팬데믹을 경험하면서, 미국이나 일본 등 주요 만화 대 국들은 출판만화의 부침을 크게 느끼게 되었다. 디지털 방식으로 만화의 유통이 점진적 으로 이동하고는 있었지만, 주된 수익처가 인쇄만화에 의지하고 있는 상황에서 만화책을 구입하는 방문 자체를 꺼리게 된 것은 직격타로 작용하게 된 것이다. 그리고 이를 계기 로 주요국들은 빠르게 만화 유통의 디지털화가 급격히 발생할 것으로 예견되고 있다. 이는 분명 한국 웹툰에게 있어서 큰 기회가 될 것이다. 다만 이 기회를 활용하기 위해서 는 적극적이고 공격적인 프로모션과 홍보가 필요하다.

가장 일반적인 방법이 IP 쇼케이스, IP 포럼과 같은 마켓이 포함된 행사를 개최하는 것이다. 정부는 기존에도 일본, 중국, 미국 등지에서 〈K-Story \& Webtoon〉과 같은 $\mathrm{B} 2 \mathrm{~B}$ 중심의 피칭과 비즈매칭이 일어날 수 있는 행사들을 지원했었다. 다만, 더 큰 기회 가 나타난 만큼 그 국가와 지역, 그리고 규모를 더 키워야할 시점이다. 또, 기존에 현지 
만화 및 캐릭터사를 대상으로 행사를 진행했다면, IP 비즈니스의 핵심은 미디어 믹스이 므로, 글로벌 OTT 플랫폼사, 게임사 등 IP를 통해 2차 산업확장이 가능한 사업자를 대 상으로 진행하는 행사로 발전시킬 필요가 있다.

또 국가 주도의 B2B행사 개최 뿐 아니라, 현지의 많은 바이어와 잠재 협력업체가 모 이는 행사에 참여할 수 있도록 지원하는 방향도 확대가 필요하다. 웹툰 IP를 보유한 업 체가 자유도를 가지고 필요한 행사와 마켓에 참여할 수 있도록 그 참가비용을 지원하는 방식 또한 효과적이다. 뿐만 아니라 통/번역, 홍보 동영상 제작, 피칭 컨설팅 등 전방위 적 지원을 통해 비즈니스 매칭 성과를 극대화할 필요가 있다.

\section{3) 기대효과}

‘스위트 홈, ‘승리호', ‘이태원 클라쓰' 등 글로벌 OTT를 통해 웹툰 IP를 활용한 2차 콘텐츠들이 전 세계적인 성공시례를 만들면서 웹툰 IP의 가치와 주목도가 높아지고 있다. 이러한 상황에서 다양한 현지 바이어와 이해관계자가 모여 비즈니스 기회를 제공하고 더 효과적인 프로그램을 구성할 경우 콘텐츠 글로벌 교역이 더 활성화 될 것으로 기대된다. 특히 웹툰 비즈니스는 웹툰 자체 거래도 크게 키울 수 있지만, 영상화를 통해 2차산업화 될 경우 수익이나 인지도와 같은 직접효과를 배가시킬 수 있어 글로벌 시장 확산에 도움이 될 수 있다. 또 현지 콘텐츠 유통 사업자와 접촉하고 행사를 통해 언론에 웹툰이 노출되면 서 웹툰이라는 디지털 만화 형식의 인지도를 높이는 데에도 기여할 것으로 예상된다.

\section{다. 트렌드 및 해외 이용자 정보 제공}

\section{1) 배경 및 필요성}

콘텐츠분야는 트렌드에 매우 민감한 분야로 웹툰 역시 그러한 특성을 보인다. 특히 특정한 분야에 대해 깊게 다루는 웹툰의 경우 상당한 고증을 필요로 한다. 가령 역사, 의료 등과 같이 전문 지식이 필요한 영역의 경우 상당한 자료 조사를 필요로 한다. 뿐만 아니라 최근에는 웹툰이 글로벌화되는 추세이기 때문에 웹툰을 수출할 대상국에서 문화 적으로 금기시하거나 문제가 될 수 있는 표현 등이 무엇인지 사전에 파악하는 일은 갈수 록 중요해질 것이다. 또한 독자의 반응을 수시로 체크하는 일도 갈수록 중요해지는 추세 이므로 수시로 시장의 반응을 체크하여 관련 정보를 얻을 수 있다면 이러한 정보는 웹툰 
기획 및 창작에도 상당히 도움을 줄 수 있다. 물론 대형 플랫폼, 스튜디오 등에서는 이와 관련된 지원이 상당수 이루어지고 있다. 웹툰 산업이 고도화되면 고도화될수록 개별 작 가의 역량보다는 시스템적, 기능적인 분업이 이루어질 수 밖에 없고 이러한 영역에서의 전문화가 이루어질 수도 있으나, 여전히 만화·웹툰에서는 소규모 창작자들이 다양한 창 의성을 바탕으로 창작활동이 이루어지는 영역이므로 이러한 트렌드에 따른 정보 제공은 웹툰산업이 보다 발전하기 위해 필요한 부분으로 여겨진다. 특히 해외 시장 및 이용자들 에 대한 정보를 개인 작가들이 얻기는 어렵다. 관련 공공기관인 한국무역투자진흥공사, 한국콘텐츠진흥원, 한국문화산업교류재단 등이 정기적으로 해외시장 동향 관련 보고서 를 내거나 해외 정보를 제공해 주고 있기는 하지만 제한된 수준에서 모호하게 제공되고 있으므로 이와 관련된 지원이 필요하다고 볼 수 있다.

\section{2) 정책방안 개요}

트렌드 및 해외 이용자 정보 제공의 필요성을 언급하는 분야는 비단 웹툰만이 아니다. 우리나라 콘텐츠산업은 이미 글로벌 시장으로 더욱 확대되고 있는 추세이기 때문에 콘텐 츠를 기획하는 많은 기업들이 트렌드 및 해외 이용자 정보를 파악하고 싶어한다. 따라서 이러한 대응 역시 웹툰만이 아니라 우리나라 콘텐츠산업 전체를 위한 지원 형식으로 구축 될 필요가 있다. 다만, 이러한 지원이 트렌드를 보여주는 정보시스템 구축 정도로만 그쳐 져서는 안된다. 상당수 기업들이 영세한 수준이기 때문에 보편적 범용 서비스를 제공해주 는 한편으로 장르 및 기업 특성에 맞춤화된 컨설팅, 데이터 제공 등이 이루어져야만 할 것이다. 이에 콘텐츠 창작자를 위한 빅데이터 분석 플랫폼을 구축하고, 국내외 $\mathrm{DB}$ 연계를 통한 정보 제공과 기획단계에서의 국내외 소비자들과의 소통 창구를 마련해 나가는 등의 방안을 고려할 수 있으며 컨설팅 기능이 포함된 데이터 바우처 등이 고려될 수 있다.

\section{3) 기대효과}

ICT 분야의 스타트업 기업들은 그로스해킹(growth hacking)73) 기법 등을 활용하여 보 다 세분화된 시장에 접근하고자 노력하고 있다. 작고 영세한 업체일수록 이러한 작은 시도

73) 기술 스타트업 기업에 의해 개발된 마케팅 기법으로 상품이나 서비스 등의 개선사항을 수시로 모니터링하 고 즉각 반영하여 성장을 유도하는 온라인 마케팅 기법을 의미함 
와 실험들에 대한 시장의 즉각적인 반응에 민감하게 반응하여야 한다. 이미 디즈니, 넷플릭 스 등 글로벌 OTT 등은 시장을 보다 세분화하여 접근하고 있어 영상물의 원천이 되는 웹 툰 산업 역시 이러한 시장 세분화에 대해 준비해야 한다. 이러한 지원들이 이루어질 경우 국외의 다양한 시장기회를 조기에 발견할 수 있어 여러모로 기회 요인을 제공할 수 있다.

\section{라. 해외 공동제작 지원}

1) 배경 및 필요성

제작 차원에서 글로벌 수준으로 콘텐츠의 품질을 높이고 소재와 문화성을 풍성하게 만들기 위한 가장 효과적인 방법은 제작과정에서부터 글로벌 협업을 시도하는 것이다. 현재 미국, 일본, 한국 등 각국의 작가들은 서로 다른 작업방식과 스튜디오 시스템을 갖 추고 있다. 따라서 교류를 통해 서로 협업할 경우 경험하지 못했던 작업방식을 접할 수 있을 뿐 아니라 소재나, 서사는 물론 아이디어를 발전시킬 수 있는 다양한 포인트과 시 너지 효과들이 협업과정에서 발생할 수 있다. 또 국내 독자들만이 아닌 해외 독자들의 변화하는 만화 소비 습관과 기호에 맞추어 콘텐츠를 제작함으로써 문화적 장벽과 정책 장벽을 뛰어 넘어 해당국에 자연스럽게 스며들 수 있다.

물론, 현재도 제작과정에서 채색이나 배경과 같은 제작과정에서 아웃소싱을 통해 중 국, 베트남 등 해외 작업자나 업체와 글로벌 협업을 진행하고 있기는 하다. 이는 산업이 커지면서 부가적인 작업의 협업은 자연스러운 과정이지만, 고도화차원에서는 중심적인 역할, 즉 콘텐츠의 내용을 구성하고 핵심 프레임을 만드는 작업에서도 글로벌 협업이 요구되고 있는 시점이다.

\section{2) 정책방안 개요}

해외 공동제작은 그 과정에 따라 사전제작(pre-production)에서의 협업, 프로덕션 (production)에서의 협업, 사후제작(post-production)에서의 협업으로 구분할 수 있 다. 즉 소재 공동개발, 공동 취재 등 공동 기획개발 과정을 함께 진행하는 사전제작 협업 에서부터 후반 작업을 각자 특화된 영역에서 진행하는 후반작업, 그리고 개별 스탭을 하나의 팀으로 결성하여 제작하는 순수 공동제작(full Co-production)에 이르기까지 
그 방식이 다양하다. 이중 후반작업의 협업은 현재도 활발하게 이루어지고 있지만 사전 제작 협업과 순수공동제작의 형태는 아직 그 선례가 없는 상황이다. 따라서 일본의 편집 자의 취재력과 소재발굴 능력, 미국의 대규모 투자와 IP 활용 전략 등을 흡수하고 웹툰 도 이러한 자원을 함께 활용하기 위한 공동제작의 시도가 활발하게 일어날 수 있도록 정부에서는 다음과 같은 지원이 필요하다.

먼저, 국제 공동제작 프로젝트를 지원하는 방안이다. 중소 웹툰 제작사를 중심으로 해 외의 인력 및 제작사와 공동 제작프로젝트를 구성을 계획할 경우 심사를 통해 그 제작 비용을 일부 지원하는 방식이다. 창작자의 제작 자유도를 보장하면서 해외의 유수 제작 사나 작가들간의 교류와 해당 업체의 자원 활용이 가능하다는 큰 장점을 지닌다. 국내 업체의 주도는 물론 컨소시엄의 형태까지 포괄하여 다양한 형태의 국제공동제작이 될 수 있도록 하여 그 대상 범위도 넓힐 필요가 있다. 다음으로는 계약 등 공동제작 과정에 서 발생할 시행착오를 줄여주는 제반 지원이 필요하다. 콘텐츠 공동제작은 이미 방송 국제공동제작 지원 사업, 영화 국제공동제작 지원 사업과 같이 타 장르에서 다양한 지원 노하우와 경험이 축적되어 있다. 따라서 각 사례와 시행착오를 파악하여 향후 웹툰 해외 공동제작에서 발생할 계약, 법/제도적 문제들을 사전에 방지하고 그 과정을 지원해주는 전방위적 지원을 구성할 필요가 있다.

\section{3) 기대효과}

해외 공동제작을 통해 기대할 수 있는 가장 큰 효과는 결과물, 즉 제작한 콘텐츠의 품질을 높여서 글로벌 히트작품이 나타나는 것이다. 대부분의 공동제작은 제작시점부터 상대국과의 접촉을 일으키며 콘텐츠의 성공을 위해 참가국들의 협조와 노력이 필수적으 로 수반된다. 이 과정에서 서로의 장점을 극대화하고 이전과 다른 차원의 작업물이 발생 하여 높은 수준의 창작물이 발생할 수 있다. 다음으로는 현지 시장 진출을 용이하게 하 고 시장 확대에 기여할 수 있다는 것이다. 공동제작에 참여한 국가들은 수익 배분 문제 뿐 아니라 상대국에 웹툰을 인식시키는 중요한 계기가 되기 때문에 홍보, 마케팅에서 긴밀한 협조와 계획적인 노력을 기울여 상대국에 대한 관심을 자연스럽게 증진시킬 수 있다. 즉, 공동제작은 기본적인 배급 범위의 확대 및 보장과 상대국의 문화적인 특성 습 득과 같은 상대국의 시장에 대한 지식을 획득할 수 있는 중요한 수단이 될 수 있다. 


\section{5. 글로벌 경쟁력 강화(Lead-up)}

\section{가. 글로벌 웹툰 이벤트 개최}

1) 배경 및 필요성

웹툰의 글로벌 외연 확장과 장르 자체의 글로벌 홍보를 극대화할 수 있는 가장 효과적 인 수단 중 하나는 대규모 글로벌 웹툰 행사를 주최하는 것이다. 그동안 샌디에고 코미 콘, 뉴욕 코미콘, 앙굴렘 국제 만화페스티벌, 국제만화가대회 등 글로벌 만화 행사에 국 내 웹툰 사업체들은 참석자로 웹툰을 소개하면서 적극 참여하고 있었다. 하지만 디지털 만화의 일종으로 소개되며 일부 참여자로 웹툰 자체를 집중조명 받게 하기에는 한계가 분명 있었다. 웹툰의 종주국으로 웹툰을 전 세계에 적극 알리며 글로벌 창작자, 스튜디 오, 에이전시, 유통사업자들이 모여 네트워킹하면서 비즈니스가 이뤄질 수 있는 대형 이 벤트가 필요한 시점에서 주도권을 지닌 행사개최가 요구되고 있다.

\section{2) 정책방안 개요}

일본의 만화인 망가가 전 세계적으로 확산되는 과정을 살펴보면 글로벌 대형 이벤트 개최가 공헌한 바가 컸다. 대표적으로 국제만화가대회(International Comic Artist Conference)는 일본에서 최초 개최된 이 행사는 동아시아 만회대회를 표방하지만, 여 기에 참여하는 작가들 사이에서는 '망가 서밋(manga summit)' 으로 불릴 정도로 일본 의 망가가 점유하고 있는 행사이다. 각국의 만화 현황을 소개하고 작가 간 교류가 이뤄 지는 이 행사에서는 일본 만화에 동경을 가진 전 세계 작가들이 모여 들게 되었고 결국 아시아 만화 시장에 망가가 중심이 되는데 큰 기여를 한 것으로 평가되고 있다. 웹툰이 한국과 일본을 중심으로 새로운 디지털 만화형식으로 각광을 받고 있는 상황에서 웹툰 에 동경과 관심을 가진 전 세계 창작자와 사업가들이 함께 모여 컨퍼런스, 전시회, 마켓 을 열렸을 경우 웹툰의 위상과 외연을 확장할 수 있다.

또 한 가지 참고해 볼만한 케이스는 프랑스의 '재팬 엑스포(Japan expo)'이다. 프랑 스에서 일본의 만화, 게임, 문화상품을 소개하고 관련 기업들이 참여하는 이행 사는 5일 동안 27만 명 이상을 동원하는 규모 있는 이벤트이다. 처음에 이 행사는 일본 정부에서 상당부분 지원하며 이뤄졌지만 현재는 자생축제로 성공하면서 특히 프랑스에 일본 만화 
와 애니메이션을 알리는데 큰 기여를 하였다.

두 이벤트를 벤치마킹하여 글로벌 수준의 대형 이벤트인 '디지털 만화/웹툰 서밋 (Digital comics/Webtoon Summit)'을 개최하여 B2C뿐 아니라 B2B가 이루어지는 대표적 만화 행사로 자리매김을 유도해야 한다. 특히 해외의 만화 중심도시를 선정하여 매해 개최하는 방식을 취함으로써 해외시장의 적극적인 참여를 이끌고 전 세계적인 만 화 축제로 포지셔닝 하는 전략이 필요하다.

\section{3) 기대효과}

웹툰을 중심으로 글로벌 만화 행사를 개최하여 웹툰 기반 글로벌 네트워킹은 물론, 홍보와 해외진출 비즈니스를 창출할 수 있을 것으로 기대된다. 즉 컨퍼런스를 통해 글로 벌 만화 창작자는 물론 사업자들이 정보를 교환하고 네트워킹하고, 마켓을 통해 웹툰 비즈니스가 이뤄지고 전시회, 코스프레 행사 등을 통해 현지 웹툰 소비자와 소통하는 대표적 글로벌 만화 축제를 만들게 되는 것이다. 이는 한국 만화뿐 아니라 한국의 문화 위상을 높이는 데에도 기여할 수 있다.

\section{나. 웹툰산업의 특수성을 반영한 법제도 개선}

1) 배경 및 필요성

한국의 만화산업에 대한 정부 지원은 2001년 김대중 정부에서 발표된 「콘텐츠 코리 아 비전 21」로부터 공식화 됐다. 이에 따라 정부 조직이 개편(2001년 5월, 문화산업국 문화콘텐츠진흥과 신설)되고 이를 전담할 운영 조직이 설립(2002년 12월, 한국문화콘텐 츠진흥원 내 만화전담팀 구성)됐다. 2002년부터 공식적으로 '만화산업육성'사업이 문화 관광부의 ‘단년도 계속사업’ 으로 추진됐고 2003년 「만화산업 진흥 5개년 계획」이 발표 되면서 규제와 단속 중심이었던 정부의 만화산업 정책이 진흥으로 전환됐다.

2012년 2월에는 ‘만화진흥에 관한 법률’이 제정되면서 독자적인 법령체계 하에서 만 화창작과 산업 진흥이 촉진되고 있다. 그러나, 출판·정보통신·문화산업·문화예술·콘텐 츠산업 등 선행 법률이 만화 분야를 포괄하고 있고 이미 시행되고 있는 사항들이 많아서 법 시행 전후로 '선언적 법률’이라는 평가가 많았다. 이에 따라 현행 법률이 웹툰산업의 
특수성을 반영하도록 개정하거나 웹툰산업을 위한 특별법이 마련되어야 한다는 요구가 있어 왔다.

\section{2) 정책방안 개요}

현 만화진흥에 관한 법률은 만화 창작 및 만화산업을 육성-지원하는 기본계획 수립, 만화 창작 및 만화산업의 활성화, 만화가 및 전문인력의 양성, 기술개발의 촉진, 협동 개발 및 연구, 유통활성화, 유통질서의 확립, 지적재산권의 보호, 국제협력 및 해외진출 지원, 이용자의 권익보호, 공동제작만화의 한국만화 인정 등에 대한 조항을 두고 있다.

그러나, 이 법의 적용 대상이 되는 만화(작품), 만화가, 만화사업자 등에 대한 구체적 인 대상을 제도적으로 관리하고 있지는 않다. 만화도서의 경우 국립중앙도서관이 국제표 준도서번호 발급과 납본 과정을 통해 도서의 생성과 작가, 출판사 등의 권리자를 확인할 수 있고 생산량에 대한 정보도 관리하고 있다. 하지만 웹툰의 경우는 이 같은 정보를 관리하는 주체가 없다. 웹툰 생산에 대한 기초 자료가 관리되고 있지 않다보니 유통 질 서 확립과 활성화, 불법 유통에 대한 지적재산권 보호, 해외 진출에 대한 지원 등이 체계 성을 지니고 발전하기 어려운 상황이다.

이에 첫째, 만화 및 웹툰사업자 신고제도의 도입이 필요하다. 만화가나 웹툰작가를 포 함해서 이를 기반으로 수익활동을 하거나 하고자 하는 이들이 출판업이나 애니메이션업 처럼 관계기관에 신고하도록 하는 것이다. 둘째, 웹툰 콘텐츠의 생산 정보 관리를 위한 독자적인 식별자 발급 제도가 필요하다. 국제표준도서번호 발급과 납본 제도를 참고할 수 있다. 셋째, 웹툰 콘텐츠의 이용자 권익 보호를 위한 표시제도 도입이 필요하다. 영상 물이나 게임물, 각종 소비재 등의 표시 제도를 검토할 수 있다. 넷째, 웹툰 콘텐츠 창작 과 유통은 국가의 문화적 자산이자 국민행복의 중요 요소라는 점에 비춰 신고와 등록을 의무화하고 출판산업에 준하여 면세 혜택을 부여해야 한다.

\section{3) 기대효과}

웹툰사업자 신고제도는 웹툰산업 진흥의 기초가 되는 생산자의 규모를 파악할 수 있 고 웹툰 콘텐츠 식별자 발급 제도는 웹툰산업의 생산량과 유통 규모를 파악할 수 있다. 또, 웹툰 콘텐츠 표시제도는 웹툰 콘텐츠 유통과 소비활동 시 발생할 수 있는 공급자와 
이용자 간의 문제를 최소화 할 수 있다. 특히, 신고와 등록 의무를 부여하고 면세사업자 로서의 권한을 부여한다면 웹툰산업의 체계적 지원과 증진, 웹툰의 유통 현대화와 소비 활성화 등의 기반이 빠르게 구축될 것으로 전망된다. 단, 신규 제도 도입과 법제화는 웹 툰산업의 특수성을 반영하고 이해관계자들 간의 협의를 통해 점진적으로 추진되어야 할 것이다.

\section{다. 기업 주도형 플랫폼 운영 지원}

\section{1) 배경 및 필요성}

최근 카카오, 네이버 등의 대형 플랫폼의 해외 진출도 늘어나고 있지만, 중소 규모의 플랫폼의 직접 해외 진출도 늘어나는 추세이다. 해외시장에서의 플랫폼 운영과 같은 사 업형태는 지금까지 우리나라에서 그렇게 많지 않았던 시례이다 보니 이 영역에서의 정 부 정책 지원 경험 역시 많지 않다. 이는 기존에 해외 진출의 형태가 가장 소극적 형태인 수출이 주를 이루었지만, 웹툰 산업의 경우 해외 국가에서 직접 서비스하는 형태로도 해외 진출이 이루어지고 있기 때문이다. ${ }^{74)}$ 과거 게임산업에서 중국으로의 진출이 상업 적 주재라는 직접 진출 형태로 이루어진 바가 있으나 중국에서의 규제가 매우 심하여 많은 기업들이 철수한 경험을 가지고 있다. 대형 웹툰 플랫폼사들에 대한 정부 지원은 어려움이 따르나 중소형 웹툰 플랫폼들에 대해서는 정부 지원이 필요할 수 있다. 또한 생각하기에 따라서 대형 웹툰플랫폼이라고 해도 해외에서 경쟁해야 하는 기업들이 글로 벌 대기업이라고 가정한다면 어느 정도의 간접지원은 함께 이루어질 필요성이 있다.

\section{2) 정책방안 개요}

웹툰산업 정책지원의에서 플랫폼 지원은 기존에도 이루어진 바 있으나 규모가 작았 고, 특정한 영역에 제한된 형태로 지원이 이루어졌다. 이는 특정한 기능, 예를 들어 홍보 및 마케팅 분야에 특정하여 지원을 하는 형태가 대부분이었다. 대부분의 중소 웹툰 플래

74) 서비스 수출의 종류는 아래 4가지 종류로 구분된다.

- (모드 1) 국경 간 공급

- (모드 2) 해외 소비

- (모드 3) 상업적 주재

- (모드 4) 자연인의 이동 
폼들은 해외 국가의 세분화된 시장의 잠재력을 보고 진출을 결정하는 경우가 많다. 따라 서 정부에서 일괄적으로 어떠한 부문에 대한 지원을 결정하기에는 어려움이 있다. 해당 국가마다 처한 환경이 다르기 때문에 플랫폼 기업들이 필요로 하는 영역이 어떠한 부분 인지를 알기 어렵기 때문이다. 현장에서 활동하는 플랫폼들이 겪는 어려움은 시장 상황 에 따라서 다양할 수 있기 때문에 이러한 지원 형태 역시 좀 더 유연해 질 필요가 있다. 따라서 기업의 수요 및 자율성을 강화한 기업 주도형 플랫폼 운영지원 사업을 고려할 필요가 있다.

\section{3) 기대효과}

과거 넷플릭스가 국내 시장에 진출하였던 당시 언론에서 국내 시장 잠식에 대한 우려 가 높았다. 방송 통신 분야에서는 이에 대한 대응책으로 웨이브와 같은 OTT를 만들기도 하였지만, 해외 진출에 대한 성공을 확신하기는 어렵다. 그에 비해 웹툰산업에서는 해외 국가로의 플랫폼 진출을 꾀하고 있는 상황이고, 사실상 우리나라 기업들 중에 이렇게 선도적인 입지에서 활동하는 분야는 상당히 드문 편이다. 웹툰 플랫폼들이 해외에 진출 하는 것은 시장을 선점하는 효과와 더불어 해외 우수 IP 확보, 그리고 향후 OSMU 등을 통한 영상콘텐츠로 발전 가능성 등을 염두에 두고 이루어지는 활동들이다. 때문에 이러 한 부문에 대한 지원이 보다 적극적으로 이루어져야 한다.

\section{6. 혁신환경 조성(Level-up)}

\section{가. 불법 유통 근절 및 IP 보호}

1) 배경 및 필요성

불법복제와 유통으로 인하여 웹툰 업계가 입는 피해는 매우 심각하다. 과거 대표적인 웹툰 불법유통 사이트였던 '밤토끼'로 인해 웹툰 시장 전체 매출의 $30 \%$ 이상의 피해가 발생한 것으로 추정하고 있으며, 불법유통 사이트 '토렌트킴'이 유통했던 드라마 및 영 화의 수는 약 45 만 건에 달한다75). 이처럼 파급력이 높은 불법 유통 사이트가 등장할

75) 중앙일보(2018.10.24.), 토렌트걸 운영자 잡고 보니 $\cdots$ 고교생이 음란사이트까지 운영 
경우 그 피해는 심각하며, 수출 감소 및 산업성장의 저해 요소로 작용한다. 폐쇄된 사이 트는 주로 주 이용자가 국내인들인 사이트가 많으나 1 개의 불법 유통 사이트가 생기면 향후 $\mathrm{n}$ 차 공유를 통해 피해가 확산되며, 저작물이 해외로 반출되어 해외 불법 유통사이 트로 공유되어 피해가 확산된다. 해외 불법 저작물 유통 URL 차단의 경우 해외 저작물 유통 사이트가 주를 이루며 해외 정부 및 유관기관 공조를 통하여 단속하는데, 저작권 보호의 주무부처인 문화체육관광부는 저작권보호원, 경찰청, 인터폴 등과 불법 사이트 단속을 수행하고 있다. 뿐만 아니라 세계지식재산기구(WIPO)에세 지식재산 분야에 대 한 국제분쟁으로 어려움을 겪고 있는 개인과 기업이 활용할 수 있는 제도인 대체적 분쟁 해결제도(Alternative Dispute Resolution, $\mathrm{ADR}$ )76)를 무료로 이용할 수 있도록 하는 등 지원을 하고 있다. 그럼에도 불구하고 전 세계적으로 발생하며, 한번 발생하면 그 피 해가 큰 불법복제 문제 해결을 위한 노력을 중요하다고 볼 수 있다.

\section{2) 정책방안 개요}

불법복제 문제와 관련하여 가장 효과적인 단속 방법은 결국 해당 국가의 정부를 통한 방법일 것이다. 우리나라 정부는 통상협상을 통하여 이러한 문제를 해결하고자 노력해 오고 있다. 한미FTA 체결 이후 우리나라는 다른 나라들과의 통상협상에서도 높은 수준 의 저작권 보호를 요구하고 반대로 요구받기도 하는 상황이다. 한중FTA를 비롯한 우리 나라가 최근까지 체결한 여러 건의 통상협상에서는 지식재산 부문을 별도로 두어 저작 권 보호 이슈를 포함하여 다루고 있다. 최근에는 우리나라는 중국, 일본, 호주, 뉴질랜드, 아세안 10 개국 등과 자유무역협정의 일환으로 역내포괄적경제동반자협정(Regional Comprehensive Economic Partnership, RCEP)을 체결하기도 하였는데, RCEP에서 역시 지식재산 보호 이슈가 다루어졌다. RCEP 체결 내용에 따르면 아세안 등 RCEP 회원국은 지식재산 보호를 위한 국제 협정 가입 및 비준 의무가 있고 저작권 보호 등을 위해 다양한 노력을 기울여야 하는 의무를 가진다. 단, 캄보디아, 라오스, 말레이시아, 미얀마, 태국, 베트남 등은 국제 협정 가입에 대해 3 15년까지 유예기간을 설정하고 있 다. RCEP에서의 저작권 규범은 저작권 보호수준이 다양한 아세안 국가들에 대하여 세

76) 대체적 분쟁해결제도(Alternative Dispute Resolution, ADR): 전통적 분쟁해결 방법인 법원의 재판절 차를 대체해 조정, 중재 등의 방식으로 분쟁을 해결하는 제도 
계지식재산기구 저작권 조약(WCT), 세계지식재산기구 실연 및 음반 조약(WPPT) 가입, 비준 의무를 명시하여 저작권 보호수준을 국제 수준으로 향상시키는 효과가 있을 것으 로 기대된다.

이처럼 저작권 보호를 위한 다양한 노력이 다각도로 이루어지고 있지만, 피해에 대한 해결은 각국 정부의 책임감 있는 대응체계 구축이 핵심이다. 국제 규범상으로 아무리 저작권 보호가 명시되어 있다 하더라도 해당 정부가 의무감을 가지고 저작권 보호를 위 해 단속 등을 적극적으로 행하지 않는다면 이러한 문제가 해결되기는 어렵기 때문이다. 때문에 이러한 해외 저작권 보호를 위한 노력은 삼각구도 체제를 확대해 나갈 필요가 있다. 우리나라가 자체적으로 이러한 불법 행위를 모니터링하면서도 해외 기관들과의 공 조체계를 통하여 모니터링을 확대하고, 개별 국가들과 통상협상 등을 통하여 의무를 부 여하고 국제 기구의 분쟁조정제도 등을 활용하는 등 다각도로 접근하여 거래 상대 국가 의 정부가 보다 적극적으로 불법 단속 활동에 나서도록 유도하는 것이 필요하다.

\section{3) 기대효과}

지속적이고 효과적인 불법 유통사이트 모니터링은 저작권 수출 증가로 인한 저작권 수지 흑자에 기여할 것으로 기대된다. 파급력이 높은 상위권 불법 유통 사이트 1 개의 폐쇄만으로도 높은 비중의 피해 발생 방지 효과가 있을 것으로 보인다. 특히 웹툰, 영상 등 산업화와 수출이 급증하고 있는 경우 산업 보호 효과가 높으며 수출의 안정적 증가에 기여할 것으로 기대된다.

\section{나. 웹툰 기획 R\&D 지원}

\section{1) 배경 및 필요성}

현행 국가 R\&D 지원은 가치사슬별 프로세스 기준에 따라 앞 단계에 해당하는 프로토 타입을 만드는 단계까지를 지원의 범주에 포함하고, 그 이후인 제품 양산 단계에 대해서 는 지원하지 않는다(박찬욱, 2016) 이러한 기준은 제조업에 기반한 기준이므로 당연히 콘텐츠산업의 특성과는 결을 달리한다. 이는 제조업의 경우 프로토타입을 만드는데까지 많은 시행착오와 비용이 들어가지만 일단 프로토타입이 완성되면 그 뒤부터는 같은 방 
식으로 대량 생산이 가능한데 비해, 콘텐츠산업의 경우 사전제작이라는 개념이 없는 장 르도 많고 제조업의 양산 단계에 해당하는 제작 단계에서 다시 원점인 기획을 수정하는 경우도 잦기 때문이다. 이러한 특성으로 콘텐츠산업 분야에서는 콘텐츠 기획 분야도 $\mathrm{R} \& \mathrm{D}$ 의 영역에 포함하여 지원해야 한다는 목소리가 높지만 아직까지 이에 대한 지원은 미흡하다.

문화·체육·관광 분야 연구개발(R\&D) 예산은 매년 조금씩 늘어나고는 있지만 국가 전 체 R\&D 예산의 $0.5 \%$ 이하 수준이다. 21 년도 CT R\&D 예산은 1,139 억원 규모로, 이는 국가 전체 R\&D 예산 27 조 4,000억원의 약 $0.4 \%$ 에 불과하다(내일신문, 2021). 국가에 서 기술 R\&D에 막대한 규모의 세금을 투입하는 데에는 기술의 경우 개발에 막대한 비 용이 들어가므로 민간 실패 영역에 해당하고, 미래 기술의 가치와 잠재력이 크고, 개발 된 기술을 이전 가능하다는 등의 이유이다.

\section{2) 정책방안 개요}

웹툰, 웹소설 등 IP산업 분야는 단일 장르이기도 하지만 콘텐츠산업 전체를 놓고 볼 때 기획·창작 R\&D 기능을 한다고 보고 과감하게 지원을 늘릴 필요가 있다. 국가에서 기술 R\&D에 막대한 세금을 투입하는데 대한 논리 역시 IP산업에 비슷한 방식으로 적용 이 가능할 것으로 보인다. 먼저 콘텐츠산업 트렌드가 빠르게 바뀌고 기술의 영향도 많이 받는 분야이기면서 시장성과를 쉽게 예측하기 어려운 분야이고 실패가 잦은 분야이다. 이로 인하여 웹소설, 웹툰 등은 로맨스 환타지 등 이미 성공한 적이 있는 분야를 중심으 로 제작이 이루어지고 있어 다양한 스토리가 부족한 상황이다. 다음으로 미국의 마블, 디즈니 등의 성공시례에서 보듯이 훌륭한 IP는 그 잠재력과 파급력이 상당하며 지속하 는 기간 역시 길다. 마지막으로 IP산업은 기업 간 이전이 가능하고, OSMU를 통한 타 장르로의 전이 역시 가능하다. 때문에 국가 콘텐츠산업 전체에 대한 기획 영역을 담당하 고 있는 IP산업, 특히 웹툰 분야에 대한 지원을 대폭 확대함으로써 콘텐츠산업 전반이 활성화 될 수 있는 계기가 마련될 수 있다.

따라서 현재 CT R\&D 지원의 수준에 버금가는 규모의 웹툰산업에 대한 지원을 통하 여 기존의 기술 R\&D에서 배제되었던 기획·창작 R\&D 영역을 지원함으로써 웹툰산업 뿐 아니라 콘텐츠산업 전체에 긍정적인 효과를 얻을 수 있다. 


\section{3) 기대효과}

코로나19 발생 이후 넷플릭스 등의 글로벌 OTT 를 활용한 콘텐츠 유통이 활성화되었 다. 작년부터 넷프릭스에서 흥행에 성공한 한국 영상물이 상당히 많아 현재 시점에서는 이것이 장점으로 부각될 수 있다. 그러나 중장기적으로는 IP의 저작권이 글로벌 OTT에 귀속되는 상황은 그리 바람직하지만은 않고, 향후 메타버스 시대에 다양한 서비스들이 결합될 것으로 예상되므로 글로벌 OTT들이 웹툰, 게임 등의 서비스를 하려는 움직임도 예상되고 있다. 최근 국내 기업들이 해외 웹툰 플랫폼 사업을 진행하고 있는 입장에서 머지않아 글로벌 대형 기업들과의 경쟁관계가 구축될 수 있는 상황이고, 역설적으로 해 외 OTT에서 인기가 있는 오리지널 한국 콘텐츠가 국내 콘텐츠 플랫폼의 해외 진출과 성장을 방해하는 경쟁자가 될 수 있다. 이러한 사업을 통하여 다수의 IP를 개발하고 국 내 기업들이 해당 권리를 보유할 수 있다면 향후 글로벌 OTT와도 경쟁이 가능하고 향후 메타버스 시대에도 주도권을 확보하는 일이 가능해질 것으로 기대된다. 


\section{제3절 정책적 제언 및 결론}

웹툰산업은 $\mathrm{K}$-pop, $\mathrm{K}$-드라마, $\mathrm{K}$-영화에 이어서, $\mathrm{K}$-만화로 글로벌 호감과 수출 시 너지 효과를 이끌어 낼 수 있는 잠재력이 높은 콘텐츠산업 장르이다. 따라서 글로벌 경 쟁력을 바탕으로 새로운 대표 한류 장르로 성장할 수 있도록 정책적 지원과 관심이 필요 한 시점이다. 본 연구에서 정리한 내용을 바탕으로 이를 위한 정책적 제언을 정리하면 다음과 같다.

먼저, 해외진출에 있어서 웹툰산업은 아직 도입기에 불과하다는 것을 정책적으로도 직시해야한다. 국내 웹툰 플랫폼업체들의 글로벌 만화 앱시장 선점과 일본 시장에서의 선전으로 인해 웹툰산업이 해외에서 이미 높은 성과를 거두고 있는 것처럼 보이지만 앞 서 살펴본 바와 같이 일부분 착시가 존재한다. 따라서 정책적 방향을 설정하고 세부방안 을 개발할 때 이미 발전된 시장으로 전제하고 해외진출 전략을 수립하기 보다는 새로운 시장에 침투할 때의 관점이 필요하다. 특히 웹툰이 디지털 만화의 표준으로 확장될 수 있도록 웹툰 자체의 홍보를 적극적으로 강화하는 지원이 요구된다.

둘째, 기존의 콘텐츠 수출지원과 다른 접근의 정책방향이 필요하다. 웹툰산업은 기존 의 여타 다른 콘텐츠산업의 해외진출과는 조금 다른 양상이 나타나고 있다. 다른 콘텐츠 산업의 경우 해외에서 이미 선점하고 있는 플랫폼이나 유통 체계를 얼마나 잘 활용하게 하고 그 체계 내에서 효과적인 수출을 이룰 수 있느냐가 해외진출에 있어서 가장 중요한 요소였다. 하지만 웹툰은 종주국 자체가 한국이며, 새로운 디지털유통 방식을 개발하여 플랫폼 자체와 그에 해당하는 제작, 유통, 소비 문법을 수출하여 디지털 콘텐츠 시장을 선점해야하는 조금 더 적극적인 수출이 요구되고 있는 상황이다. 마치 K-pop이 음악에 는 속해있지만 장르화 되어 효과적인 수출이 이루어졌고 그 수출 정책도 그 장르화 되는 확산을 지원하고 있는 것처럼 웹툰산업도 웹툰 콘텐츠 자체의 수출만 볼 것이 아니라 웹툰 자체의 확산에 기여하는 차원까지 고려해야 한다. 
마지막으로, 웹툰산업의 글로벌 경쟁력을 강화하기 위해서는 산업자체의 저변과 기반 의 폭을 넓혀야 한다. 현재의 웹툰산업은 일부 장르에 지나치게 취중되어 있고, 한국적 정서에 최적화된 콘텐츠가 다수이며, 소재가 한정되어 있고, 타겟이 젊은 세대에 집중되 어 있는 등 그 폭이 좁은 형태로 발전하고 있다. 이는 국내산업 뿐 아니라 해외진출에 있어서도 그대로 적용되는 사항들이다. 해외의 잠재 소비자가 웹툰 콘텐츠를 접하게 되 어 웹툰을 구독하기 시작되었을 때, 로맨틱 판타지 장르와 환생과 같은 일부 소재를 반 복적으로 접하게 되면 장르의 충성도가 발생하기도 전에 피로도가 유발될 수 있다. 또한 현지의 정서와 동떨어진 한국적인 내용만이 담기고 국제적이고 보편적인 가치와 동떨어 진 내용들이 담기게 될 경우에도 한계점이 뚜렷하게 나타날 것이다.

이상의 정책적 사항들을 고려하여 적절한 지원이 이루어지고 지속적으로 웹툰산업 관 계자들이 경쟁력을 강화하며 성장해 나갈 때, 웹툰산업은 새로운 한류 장르는 물론, 디 지털 만화의 글로벌 표준(global standard)이 될 것으로 기대한다. 


\section{참고문헌}

- 문화체육관광부(2019), 「만화산업 발전 계획」.

- 미래에셋대우(2020.12.), 모바일 시대의 웹툰은 새로운 대세 콘텐츠.

- 미래에셋대우(2020.02.), NAVER 웹툰 글로벌 성장세 또 확인.

- 유안타리서치(2021.01), 웹툰 next korean wave.

- 이성민(2017), 「웹툰 미주 시장 현황 및 시사점」, 서울: 한국문화관광연구원.

- 정보통신산업진흥원(2017), 「웹툰플랫폼 글로벌화 전략연구」.

- 한국투자증권(2019.09.), 디즈니도 마블도 시작은 만화였다.

- 한국만화애니메이션학회(2015), 「웹툰 플랫폼의 산업적 진화와 세계화 전략 연구」.

- 한국만화애니메이션학회(2016), 「웹툰 플랫폼의 비즈니스모델(BM)과 스핀오프(Spin off)전략의 생태계 진화 연구」.

- 한국콘텐츠진흥원(2017), 「모두 IP의 시대: 콘텐츠 IP활용 방법과 전략」.

- 한경 비즈니스(2021.06.), 네이버 vs 카카오, 달아오르는 웹툰 전쟁.

- 한경 비즈니스(2021.07.), 네이버 웹툰, 미국 찍고 글로벌 공략 개시.

- 한국국제문화교류진흥원(2021), 「한류 나우: 트랜스미디어 환경 속 웹툰의 가능성」.

- 한국예술경영학회(2018), 「한국 웹툰 플랫폼의 경쟁력과 전략」.

- 한국콘텐츠진흥원(2020), 「2020 만화 산업백서」.

- 한국콘텐츠진흥원(2020), 「만화 이용자 실태조사 보고서」.

- 한국콘텐츠진흥원(2020), 「만화웹툰 불법유통 실태조사」.

- 한국콘텐츠진흥원(2020), 「만화산업분류체계 개편 및 분석연구」.

- 한국콘텐츠진흥원(2020), 「웹툰 사업체 실태조사 보고서」.

- 한국인터넷방송통신학회(2021), 「한류의 비즈니스 확장에 관한 연구 :창의성 유형 모 델 기반으로.

- $\mathrm{NH}$ 투자증권(2019.12.), 디증 완료된 콘테츠 웹툰 웹소설의 산실. 
- Gabilliet, J. P.(2008), Of Comics and Men: A Cultural History of American Comic Books. (B. Beaty \& N. Nguyen, Trans.), US: University Press of Mississippi.

- Mayes, T.(2016), A New Storytelling Era: Digital Work and Professional Identity in the North American Comic Book Industry (Doctoral dissertaion). Available from ProQuest Dissertations and Theses database.

- Brienze C. \& Johnston P.(Eds.). (2016), Cultures of Comic Work. London: Palgrave Macmillan.

- Perren. A. \& Steirer. G.(2021), The American Comic Book Industry and Hollywood. London: British Film Inst.

- Palmer, D.(2010), The Evolution of the American Comic Book Industry: Are We Entering the Third Wave?. Advances in Business Research, 1(1), 232-239.

- Norcliffe, G. \& Rendace. O.(2003), New Geographies of Comic Book Production in North America: The New Artisan, Distancing, and the Periodic Social Economy. Economic Geography, 79(3), 241-263.

- Hionis, J. \& Ki. Y.(2019), The economics of the modern American comic book market. Journal of Cultural Ecnomics, 43, 545-578.

- Woo. B.(2018), Is There a Comic Book Industry?. Media Industries 5.1.

- Beaty. B.(2010), The Recession and the American Comic Book Industy: From Inelastic Cultural Good to Economic Integration. Taylor \& Francis

・デジタルコンテンツ協会(2015),「マンガ制作・流通技術ガイド」

・中野晴行(2004)，「マンガ産業論」，東京：筑摩書房.

・岡田美弥子(2014),「マンガビジネスの生成と発展: コミックのビジネスシステムの解明, 『經濟學研究 (63), 北海道大学大学院経済学研究科.

- 川井良介(2004), 「現代日本の雑誌出版。『出版研究』(35), 日本出版学会.

・星野渉(2009),「日本出版産業の構造変化-杂誌メディアの低迷とデシタル技術の影響」,『 出版研究』(39), 日本出版学会.

・山森宙史(2015),「「コミックコーナー」の社会史：1970-80年代の小売書店空間における マンガの市民権の成立過程」『マス・コミュニケーション研究』(87), 日本マス・コミュ ニケーション学会. 
・ITmedia(2021), 「「鬼滅」「巣ごもり」でコミック市場規模は史上最高に・電子版好調の内 実を分析する」。

・ unistyle(2021), 「出版業界の2020年の市場規模と現状を徹底解説！」

・コミックマーケット準備会・コンテンッ研究チーム(2011), 「コミックマーケット35周 年調查 調査報告」

- 全国出版協会·出版科学研究所(2021),「2020年のコミック市場規模発表」

・総務省情報通信政策研究所(2021),「メディア・ソフトの制作及び流通の実態に関する調 查研究

- 総務省·経済産業省(2021),「2020 年経済構造実態調査報告書二次集計結果：新聞業、 出版業」

・文化通信(2020)，「コミックが支える出版流通」.

- 文化通信(2020),「出版不況，は終わった？いよいよ明確になった市場構造の変化. 



\section{ABSTRACT}

\section{Study on Improvement for Overseas Expansion of the Webtoon Industry}

Yang Ji Hoon

The main goal of the research is to improve overseas expansion of the webtoon industry. For this purpose, the following research process was carried out. First, by objectively diagnosing the current status and characteristics of the webtoon industry, special strengths and problems that can be maximized in overseas expansion were derived. By analyzing not only the characteristics of the webtoon industry itself, but also the major issues and characteristics, it was attempted to examine the advantages and global competitiveness of digital comics unique to webtoon. Next, by clearly analyzing the current status of the digital comics market by region and the status of advancement into the webtoon industry, we tried to derive difficulties and opportunities for overseas expansion. In particular, by analyzing the possibilities of digital comics in major overseas countries and regions such as Japan, the United States, Europe, and Southeast Asia, we tried to examine the opportunities and possibilities of the webtoon industry in detail. In addition, by analyzing the current government policy direction and current detailed projects related to the webtoon industry's overseas expansion support, it was diagnosed whether the webtoon industry is responding appropriately in light of the current situation, and improvement directions and detailed points for improvement were derived. Finally, by synthesizing the results of the analysis, practical strategic directions and promotion plans were established to revitalize the overseas expansion of the webtoon industry. 
The key policy considerations identified through the research process to establish an effective webtoon industry's overseas advancement promotion plan can be summarized in the following three categories. First, in terms of overseas expansion, the webtoon industry is still in its introductory stage. It seems that the webtoon industry is already making high achievements abroad due to the domestic webtoon platform companies' dominance in the global comics app market and their success in the Japanese market, but this was partially an optical illusion. Although it is showing significant achievements in the app market, the webtoon industry's share in the global digital comics market is still very small. In terms of awareness, foreign countries recognize webtoon as a platform that provides digital comics, and the recognition of the unique format and genre of webtoon as well as the brand of webtoon itself is low. Therefore, when setting policy directions and developing detailed measures, it is necessary to emphasize the characteristics and strengths of the webtoon industry only from the perspective of penetrating into a new market, rather than assuming an already developed market and establishing a strategy for overseas expansion and strengthening public relations. Second, there is a need for a policy direction different from the existing content export support. The webtoon industry is showing a slightly different aspect from the overseas expansion of other content industries. In the case of other content industries, the most important factor in overseas expansion was how well it was possible to utilize the platform or distribution system already preoccupied overseas and to achieve effective export within that system. However, webtoon itself is the home country of Korea, and a more aggressive export is required to preempt the digital content market by developing a new digital distribution method and exporting the platform itself and the corresponding production, distribution, and consumption form. Third, in order to strengthen the global competitiveness of the webtoon industry, it is necessary to widen the base of the industry itself and the breadth of its foundation. The current webtoon industry is developing in a narrow form, with too much concentration on some genres, a lot of content optimized for Korean sentiment, limited material and concentration on the younger generation. This applies not only to the domestic industry but also to overseas expansion. When potential overseas consumers come 
into contact with webtoon content and start subscribing to webtoon, if they repeatedly encounter some material such as romantic fantasy genre and reincarnation, fatigue may be induced before the genre's loyalty occurs. In addition, when only Korean content that is separated from the local sentiment is included, and content that is separated from international and universal values, the limitations will be evident.

In this study, by synthesizing these results, five directions were established: base expansion, manpower nurturing and education, market development and demand creation, global competitiveness reinforcement, and innovation environment creation, and detailed strategic plans were presented. When appropriate support is provided centering on the suggested direction and the webtoon industry officials continue to strengthen their competitiveness and grow, it is expected that the webtoon industry will become the 'Global Standard' of digital comics.

\section{Keywords}

Webtoon, Digital Comics, Contents Export Policy, Digital Contents Trade 

집필내역

연구책임

양지훈 한국문화관광연구원 연구원: 연구총괄, 제 1 장, 제 2 장, 제 3 장, 제 5 장, 제6장, 제 7 장

연구진

박찬욱 한국문화관광연구원 연구위원: 제2장, 제3장, 제4장 4절, 제6장 2절

김병수 목원대학교 웹툰애니메이션게임학부 교수: 제6장 2절

박석환 한국영상대학교 만화웹툰콘텐츠학과 교수: 제6장 2절

연구 참여

김소원 상지대학교 문화콘텐츠학과 외래교수: 제4장 2절

김은정 이화여자대학교 국제대학원 한국학 박사: 제4장 3절

백경지 홍익대학교 문화예술경역학 석사: 제2장 3절

\section{웹툰산업 해외진출 진흥 방안 연구}

발행인 김대관

발 행 처 한국문화관광연구원

서울시 강서구 금낭화로 154

전화 02-2669-9800 팩스 02-2669-9880

http://www.kcti.re.kr

인 쇄 일 2021년 10월 15일

발 행 일 2021년 10월 15일

인 쇄 인 (사)한국장애인이워크협회 일자리사업장

I S B N 978-89-6035-881-2 93300

DOI https://doi.org/10.16937/kcti.rep.2021.e19

이 연구보고서를 인용하실 때는 다음과 같은 사항을 기재해 주십시오.

양지훈(2021), 웹툰산업 해외진출 진흥 방안 연구, 한국문화관광연구원 


\section{OPEN}

한국문화관광연구원

서울특별시 강서구 금낭화로 154

전화 02-2669-9800

팩스 02-2669-9880

www.kcti.re.kr 